\title{
Cation Contamination in Polymer Electrolyte Fuel Cells: Impacts, Mechanisms, and Mitigation
}

Md. Aman Uddin

aman.uddin@engr.uconn.edu

Follow this and additional works at: https://opencommons.uconn.edu/dissertations

\section{Recommended Citation}

Uddin, Md. Aman, "Cation Contamination in Polymer Electrolyte Fuel Cells: Impacts, Mechanisms, and Mitigation" (2016). Doctoral Dissertations. 969.

https://opencommons.uconn.edu/dissertations/969 


\title{
Cation Contamination in Polymer Electrolyte Fuel Cells: Impacts, Mechanisms, and Mitigation
}

\author{
Md. Aman Uddin, PhD \\ University of Connecticut, [2016]
}

Polymer electrolyte fuel cells (PEFCs), a promising source of clean energy in automotive application, still require durability improvement before commercialization. Cationic contaminants originated from either the ambient air (e.g. roadside contaminants) or from the corrosion of stack and balance of plant components can significantly decrease the performance and life time of PEFCs.

This work is focused on the experimental and theoretical study of the effects of cationic contaminants on the performance of PEFCs. Specifically, this work assesses the impact of a foreign cation on the durability of PEFCs, clarify the mechanisms responsible for the performance degradation, devise performance recovery strategies after exposure to a foreign cation, and complete an analytical model.

In the cation contamination model, a catalyst agglomerate model was utilized and for the first time, a decrease in oxygen concentration in the catalyst layer was found due to cation contamination. During experimental studies, it was found that ingress of cation into the membrane increased high frequency resistance (HFR) more than $50 \%$ in the individual membrane layer and water management was significantly affected by cation contamination which may result in salt precipitation causing serious mass transport losses, and salt was preferentially deposited at the outlet of the cell at our operating conditions. It was also found that gas diffusion layer (GDL) played an important role in 


\section{Md. Aman Uddin- University of Connecticut, [2016]}

the transport of cations in as well as out of the membrane electrode assembly (MEA), and hydrophobic nature of the GDL can act as a barrier to the transport of cation solution.

Based on experimental and computational model, mitigation methodologies for cation contamination were designed depending on the presence of contaminants in various parts of the fuel cell. Cation contaminants from the membrane can be completely removed by re-protonating the membrane using acidic solution. For removing salt deposit from GDL and flow field, an ex-situ acid flush technique was utilized and salt deposit on flow field was completely removed, whereas some white patches of salt deposit still was observed on the GDL. Ex-situ mitigation process using acidic solution worked well, but additional factors need to be identified that hinder the full recovery process. 


\title{
Cation Contamination in Polymer Electrolyte Fuel Cells: Impacts, Mechanisms, and Mitigation
}

\author{
Md. Aman Uddin
}

B.S., Bangladesh University of Engineering and Technology, 2009

\author{
A Dissertation \\ Submitted in Partial Fulfillment of the \\ Requirements for the Degree of \\ Doctor of Philosophy \\ at the \\ University of Connecticut
}

[2016] 
Copyright by

Md. Aman Uddin

[2016] 


\author{
APPROVAL PAGE \\ Doctor of Philosophy Dissertation
}

\title{
Cation Contamination in Polymer Electrolyte Fuel Cells: Impacts, Mechanisms, and Mitigation
}

Presented by

Md. Aman Uddin, B.S.

Major Advisor

Ugur Pasaogullari

Associate Advisor

Amir Faghri

Associate Advisor

Michael Pettes

Associate Advisor

Prabhakar Singh

Associate Advisor

Stephen Stagon

University of Connecticut

[2016] 
To the memory of my mother

and my school teachers, Khurshed Alam and Foyaz Ahmed, who advised and inspired me throughout my life. 


\section{ACKNOWLEDGMENTS}

I would like to thank my major advisor Dr. Ugur Pasaogullari for his continuous support and encouragement over my four and half year stay at the Center for Clean Energy Engineering. Without his guidance and advice, this work would not have been possible. I would also like to extend my gratitude to my $\mathrm{PhD}$ committee members: Dr. Amir Faghri, Dr. Prabhakar Singh, Dr. Michael Pettes, and Dr. Steve Stagon.

I am grateful to Mr. Leonard Bonvile for his advice and instructions on my research and publications. Thanks to my present and past group members: Jae Park, Charles Banas, Ozan Ozdemir, Eric Leamon, Dr. Selvarani Ganesan, Dr. Xiaofeng Wang, Dr. Jing Qi, Dr. Navvab Khajeh Hosseini Dalasm, and Dr. Richard Fu for their helpful discussion and help in the experiment.

I wish to thank all the center staff including Peter, Garry, and Mark for helping in my experiment, and Sheila, Terry, Amy, and Raelene for their administrative assistance.

I would like to acknowledge financial support from US Department of Energy.

Thanks to my parents, brothers, sisters, and other family members for their support and patience. Thank to my friends for the great moments we shared over the years.

Finally, I would like to extend my gratitude to my beloved wife Tania for her love, patience, and unending support over the period of my journey. 


\section{Table of Content}

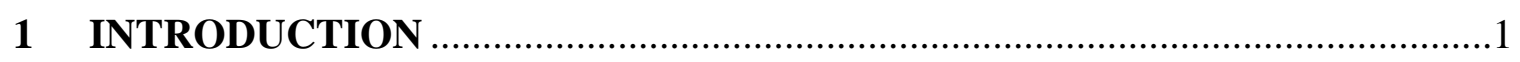

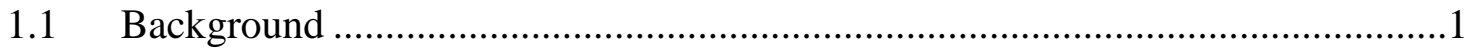

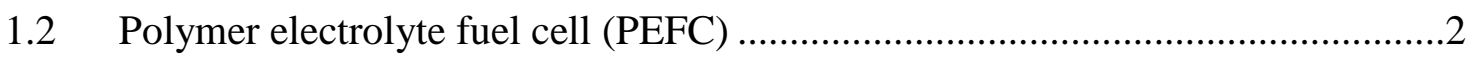

1.3 Challenges in polymer electrolyte fuel cell .....................................................

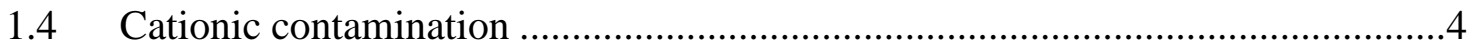

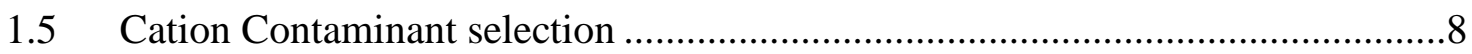

1.6 Overall objectives and scope ......................................................................

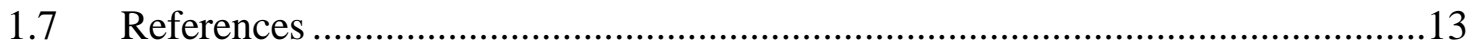

2 EFFECT OF CHLORIDE ON POLYMER ELECTROLYTE FUEL CELLS IN

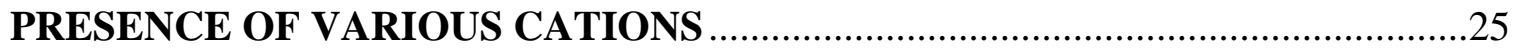

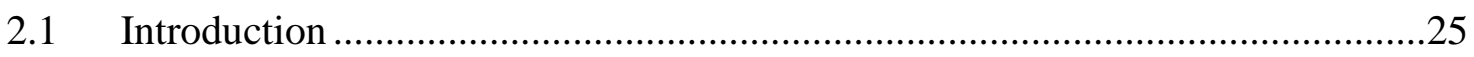

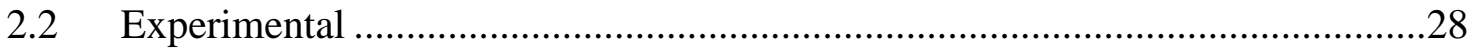

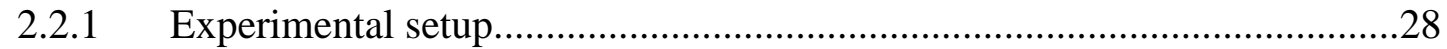

2.2.2 Contaminants and operating conditions .................................................28

2.2.3 Cell Testing and diagnostic measurement ..................................................29

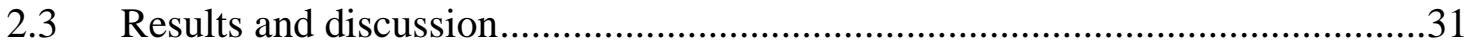

2.3.1 Effects of $\mathrm{HCl}$ and chloride salts ............................................................

2.3.2 Effects of relative humidity $(\mathrm{RH})$ on $\mathrm{AlCl}_{3}$ contamination .........................34

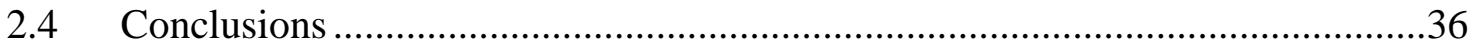

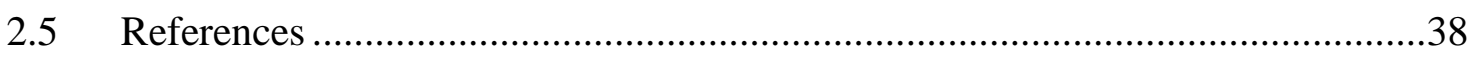

\section{COMPUTATIONAL MODELING OF FOREIGN CATION}

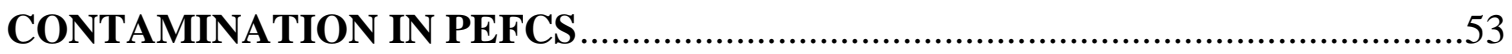

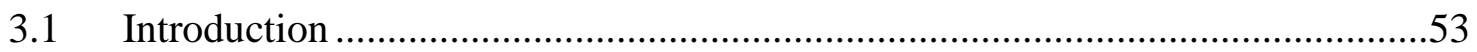

3.2 Mathematical Model ............................................................................55

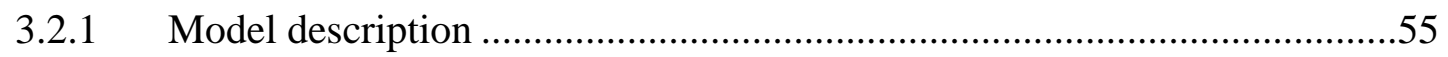

3.2.2 Proton/Foreign Cation Transport .........................................................56

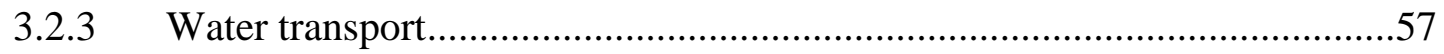

3.2.4 Oxygen transport..............................................................................59

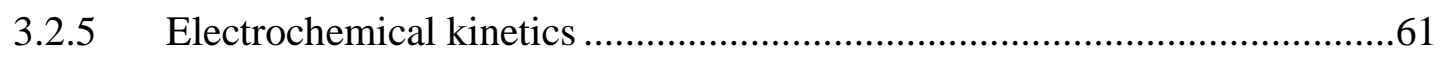

3.2.6 Boundary conditions ...............................................................................63 
3.3 Numerical Method..............................................................................63

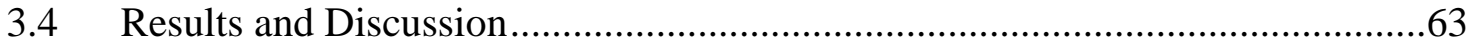

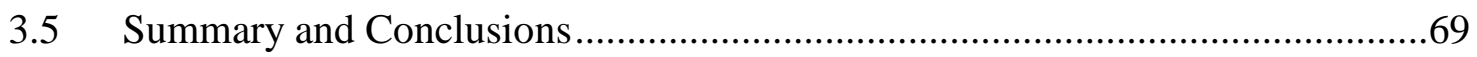

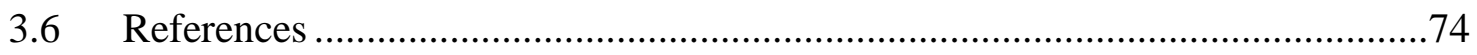

4 DISTRIBUTED CATION CONTAMINATION FROM CATHODE TO ANODE DIRECTION IN POLYMER ELECTROLYTE FUEL CELLS ................90

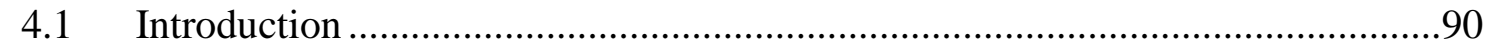

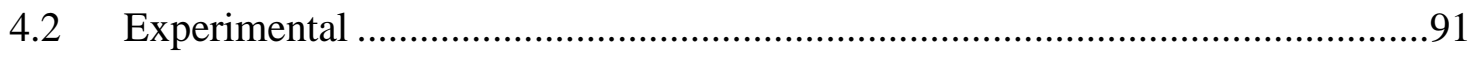

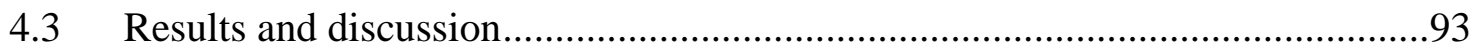

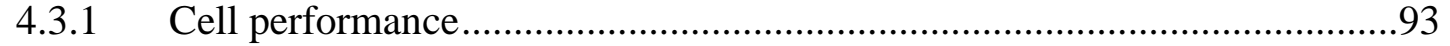

4.3.2 Through plane contamination effect ....................................................95

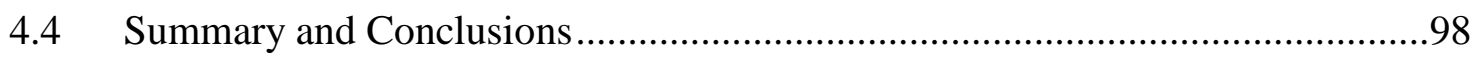

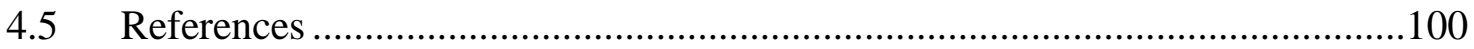

5 DISTRIBUTED EFFECTS OF CALCIUM ION CONTAMINANT ON POLYMER ELECTROLYTE FUEL CELL PERFORMANCE...........................110

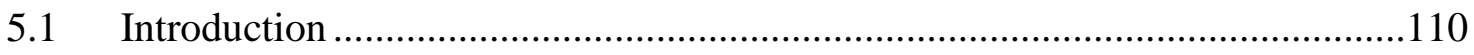

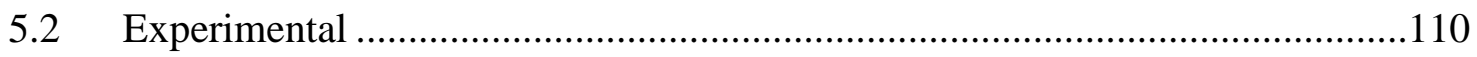

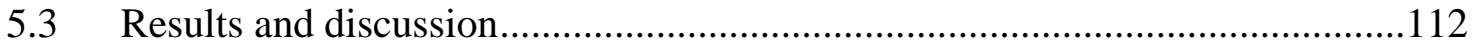

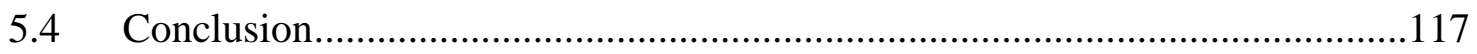

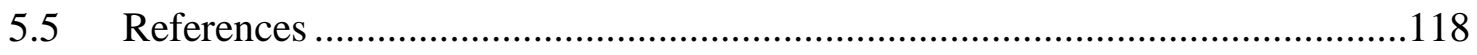

6 CATHODE CATALYST LAYER THINNING IN POLYMER

ELECTROLYTE FUEL CELL: A CATION CONTAMINATION EFFECT ........127

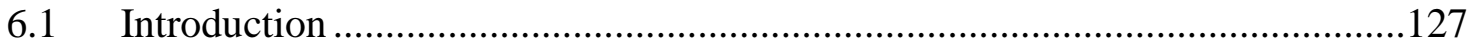

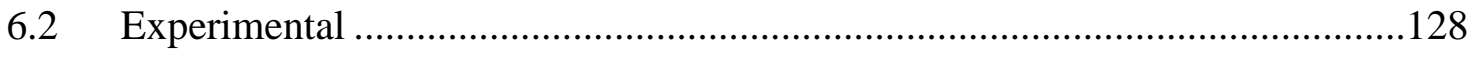

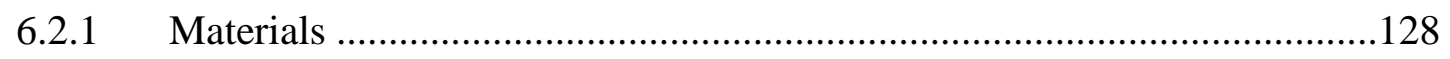

6.2.2 CCM Contamination Procedure ...........................................................129

6.3 Ion Exchange Capacity measurement .......................................................129

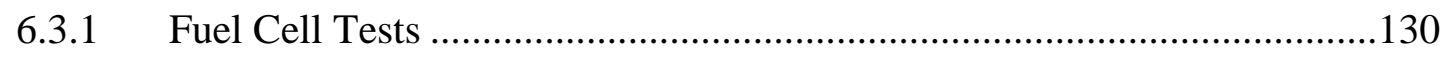

6.3.2 MEA Cross-section Analysis ..................................................................131

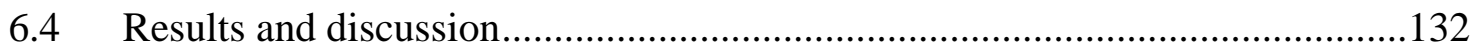

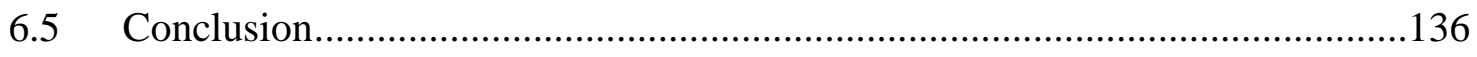

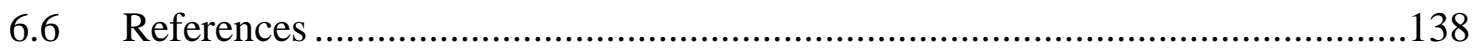




\section{CATION CONTAMINATION AND MITIGATION IN POLYMER}

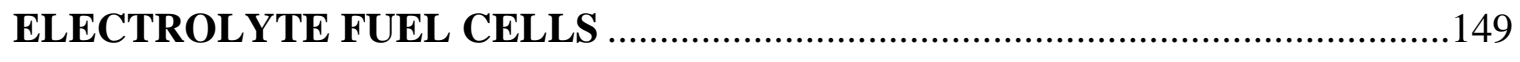

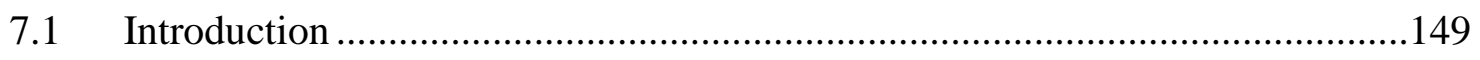

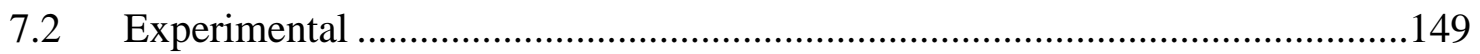

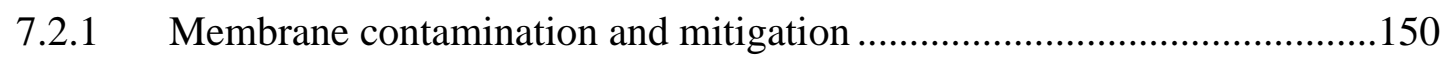

7.2.2 GDL/flow field contamination and mitigation .....................................150

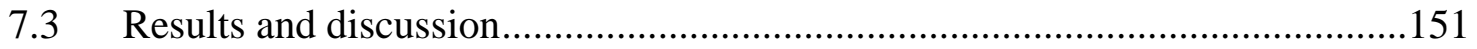

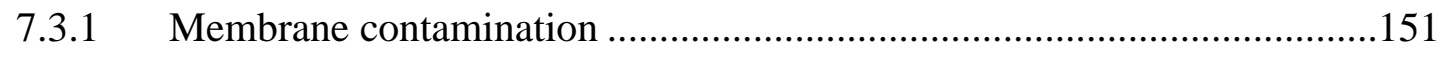

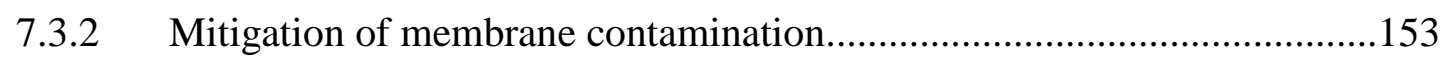

7.3.3 Mitigation of GDL/flow field contamination ........................................153

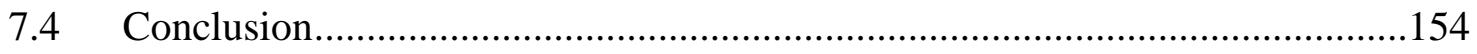

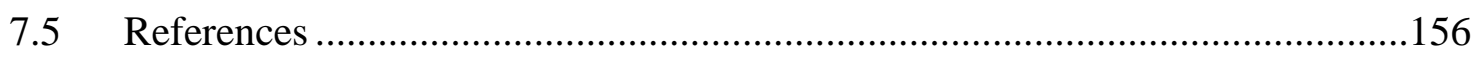

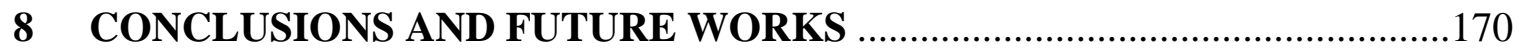




\section{INTRODUCTION}

\subsection{Background}

Emission of greenhouse gases due to fossil fuel burning is causing global warming and long lasting changes in all components of the climate. To limit climate change, substantial emissions reduction is essential over next few decades and near zero emissions by the end of the century. ${ }^{1}$ Therefore, the environment concerns force us to seek for clean and alternate energy sources. Owing to their zero emission and high efficiency, the fuel cell technologies have received significant attention recently.

Fuel cells are electrochemical devices that convert chemical energy to electrical energy. If hydrogen is the fuel, water and heat are the only byproducts. The fuel cell was first developed by William Grove in $1839 .^{2}$ It was operated with hydrogen and oxygen with separate platinum electrodes in dilutes sulfuric acid electrolyte solution. Although a lot of others attempts are made to make electricity from fuel cells, little practical development of fuel cells occurred until the late 1950s, when NASA used fuel cells in the Apollo and Gemini space missions.

Currently, there is a great interest in using fuel cells in transportation as well as portable and residential power generation devices. Unlike common power generation by combustion of fuel, fuel cell efficiency is not limited by the Carnot efficiency. Therefore,

this process has a theoretical efficiency of $92 \% .^{3}$ In practical applications, efficiencies of fuel cells are reported to be 40 to $60 \% .^{4}$ Although operating principles are similar, there are various fuel cells. These can be classified on the basis of material used for the 
electrolyte. Table 1.1 summarizes types of fuel cells that are most common. This thesis work is based on polymer electrolyte fuel cell.

\subsection{Polymer electrolyte fuel cell (PEFC)}

Polymer electrolyte fuel cell (PEFC) is a potential candidate for automotive vehicles and stationary power generation. PEFC comprises polymer membrane as solid electrolyte and platinum based porous carbon electrodes as the anode and cathode. They use hydrogen and oxygen as a fuel and an oxidant for anode and cathode, respectively. Generally, pure hydrogen needs to be supplied as a fuel and oxygen can be used from the air.

A simple schematic of PEFC is shown in Fig. 1.1. Membrane electrode assembly (MEA) is the heart of the PEFC which includes gas diffusion layers (GDLs), catalyst layers (anode and cathode), and polymer membrane.

GDL is an important component of the PEFC. Typical material for GDL is carbon paper or cloth. GDL facilitates transport of reactants to and products from the electrode. It conducts electron from electrode to the current collector, supports the electrolyte, and provides an even distribution of axial load.

Membrane is the key material to the PEFC. It provides several important functions within the cell. It provides a means of conduction of proton from anode to cathode and separates reactants within the cell. PEFC using an acidic polymer electrolyte membrane was first invented in the 1960's by Willard Thomas Grubb and Lee Niedrach of General Electric. ${ }^{6}$ Originally these fuel cells used hydrocarbon based sulfonated polystyrene membrane. Later, these membranes are replaced by perfluorinated sulfonic acid (PFSA) membrane which was more stable than previous one. PFSA membranes, 
such as Nafion ${ }^{\circledR}$ of DuPont ${ }^{\circledR}$, consist of a polytetrafluoroethylene (PTFE) backbone $\left(\right.$ Teflon $\left.^{\circledR}\right)$, with perfluorinated-vinyl-polyether side chains terminating with sulfonic acid group as shown in Fig. 1.2. Teflon provides resistance to chemical attack, electrical insulation, and structural stability. The backbone of the polymer is hydrophobic and the sulfonic acid group of the side chain is hydrophilic. In the side chain, $\mathrm{H}^{+}$attaches with the $\mathrm{SO}_{3}{ }^{-}$due to the ionic bonding. When the membrane is hydrated, the hydrophobic backbones of polymer repel water and the hydrophilic acidic side chains store water. As a result, distance between hydrated sulphonic acid ions will be smaller leading to interconnected channels of water throughout the membrane and allow $\mathrm{H}^{+}$to move freely from one side chain to the other in hydronium ions $\left(\mathrm{H}_{3} \mathrm{O}^{+}\right)$from. This is the dominant mechanism of the transport of protons from the anode to the cathode. Hydration of the membrane is necessary for proton conductivity.

Another key component of the fuel cell is catalyst on both sides of the membrane. Typical catalyst is platinum particles dispersed on a carbon support. Hydrogen enters through the anode and oxidizes to produce protons and electrons in the anode catalyst layer (ACL), as shown in Eq. 1. Electrons travel through the external circuit and protons are transported through the membrane. Air enters through the cathode and reacts with protons and electrons to form water in the cathode catalyst layer (CCL), as shown in Eq. 2. Total cell reaction is shown in Eq. 3.

Anode:

$$
\mathrm{H}_{2} \rightarrow 2 \mathrm{H}^{+}+2 \mathrm{e}^{-} \quad \mathrm{E}^{\circ} \text {, anode: } 0.00 \mathrm{~V}
$$


Cathode:

$$
\frac{1}{2} \mathrm{O}_{2}+2 \mathrm{H}^{+}+2 \mathrm{e}^{-} \rightarrow \mathrm{H}_{2} \mathrm{O} \quad \quad \mathrm{E}^{\circ} \text {, cathode: } 1.23 \mathrm{~V}
$$

Cell:

$$
2 \mathrm{H}_{2}+\mathrm{O}_{2} \rightarrow \mathrm{H}_{2} \mathrm{O} \quad \mathrm{E}^{\circ} \text {, cathode }-\mathrm{E}^{\circ} \text {, anode }=\mathrm{E}^{\circ} \text {, cell: } 1.23 \mathrm{~V}
$$

\subsection{Challenges in polymer electrolyte fuel cell}

PEFC's cost and durability are still major concerns for the commercialization. ${ }^{4}$ PEFCs will need to have a durability of 5,000 hours (equivalent to 150,000 miles of driving) at a cost of $\$ 30 / \mathrm{kW}$ with less than $10 \%$ loss of performance for automotive applications, and about 60,000 to 80,000 hour durability, at a capital cost of about $\$ 1,000-1,500 / \mathrm{kW}$ depending on size and application for stationary power generation. ${ }^{8}$ The US Department of Energy estimates the current status (2013) of PEFC to be 2500 hours durable at a cost of $\$ 49 / \mathrm{kW}$ (projected for high volume production at 500,000 systems per year). ${ }^{8}$ Lately, immense research and development is focused on producing a durable and cost-effective PEFC system.

\subsection{Cationic contamination}

Durability is a major issue for the commercialization of polymer electrolyte membrane fuel cells (PEFC) $;{ }^{9}$ and cationic impurities significantly reduce the performance and durability of PEFCs. ${ }^{10}$ These cationic impurities may originate from the water in the humidifier, salt aerosols in the air or fuel stream, and the corrosion of fuel 
cell stack system components, such as bipolar plates, seals, inlet/outlet manifolds, humidifier reservoirs, and cooling loops. ${ }^{9-13}$

To understand the impact and mechanism of cation contamination in PEFC, several modeling ${ }^{14-20}$ as well as experimental studies ${ }^{21-41}$ have been conducted, including ex-situ contamination of the polymer membrane with various cations before the test and injecting cations into the air or fuel stream during the cell test. Okada and co-workers extensively investigated the effect of various metal cations $\left(\mathrm{Li}^{+}, \mathrm{Na}^{+}, \mathrm{Ca}^{2+}, \mathrm{Fe}^{2+}, \mathrm{Ni}^{2+}\right.$, $\mathrm{Cu}^{2+}, \mathrm{Rb}^{2+}, \mathrm{Cs}^{+}$) on the oxygen reduction reaction (ORR) kinetics, thermodynamics, and transport properties of perfluorosulfonic acid (PFSA) membranes. ${ }^{10,14,22-26}$ They reported that with the exception of $\mathrm{Li}^{+}$, all foreign cations have higher affinity towards the sulfonic acid side chain of the PFSA ionomer than proton and the multivalent cations show higher affinity for sulfonic acid groups than the mono-valent cations. Higher affinity is a result of larger cations having, in general, greater amounts of electrostatic interaction with the sulfonate sites. Lithium is the only ion that does not follow this trend because of its unique electrostatic interactions. Once the cations enter the ionomer, they replace protons resulting in reduced ionic conductivity and water content, as well as lowering gas permeability through the ionomer. ${ }^{14,} 15,22-26$ Later, other researchers confirmed the findings of Okada group. ${ }^{18,28,33,39,41}$

Sulek et al. tested PEFCs with polymer membranes that were pre-immersed with four different metals $(\mathrm{Al}, \mathrm{Fe}, \mathrm{Ni}$, and $\mathrm{Cr})$ sulfate $\left(\left(\mathrm{SO}_{4}\right)^{2-}\right)$ solutions and found that the performance degradation order for those metals ions are : $\mathrm{Al}^{3+}>>\mathrm{Fe}^{2+}>\mathrm{Ni}^{2+}, \mathrm{Cr}^{3+} \cdot{ }^{31}$ Pozio et al. investigated the degradation in PEFC that was caused by iron contamination from SS316L end plates and reported that contamination of the membrane electrode 
assemblies with iron led to degradation of the ionomer, revealed by a massive fluoride losses. ${ }^{27} \mathrm{Li}$ et al. reported that a level of only $5 \mathrm{ppm}$ of $\mathrm{Fe}^{3+}$ in the air stream caused significant cell performance degradation due to the formation of pinholes in the membrane. They suggested that these pinholes may have been promoted by the enhanced production of peroxide radicals catalyzed by Fe species through Fenton's reaction. ${ }^{29}$ They also reported that $\mathrm{Al}^{3+}$ reduced ORR kinetics and changed the ORR mechanism from a predominantly 4-electron pathway towards a more 2-electron pathway. Okada et al. also reported that oxygen reduction reaction (ORR) is suppressed by cation contamination either through lowered oxygen gas transport or through suppressed charge transfer reactions by cations. ${ }^{10,42}$ Moreover, cations can act as a catalyst for peroxide radical formation resulting membrane degradation. ${ }^{27,29}$

The above described effects of cationic impurities on PEFC can be summarized in three modes of deterioration in the fuel cell performance. ${ }^{10}$ The first is the effect on membrane bulk properties, e.g., lowering of membrane ionic conductivity, water content, etc. Cation presence in the membrane other than by $\mathrm{H}^{+}$leads to concentration polarization inside the membrane, and therefore, lowering of the cell voltage and efficiency.

The second is the effect on water management inside the membrane. Water management in a PEM is dependent on two major factors. ${ }^{43}$ The first is related to the total amount of water in the membrane. Second factor is electro-osmotic drag. As protons or other cations are transported across the membrane they drag water molecules along with them. This factor is characterized by an electro-osmotic drag coefficient which describes the number of water molecules dragged along with each cation. Cationic contamination 
affects both of these parameters resulting in membrane drying and lowering of membrane conductivity.

The last cation effect is the degradation of the cathode catalyst layer. This occurs in two ways: one through altered water content and resulting membrane dehydration, and the other through degradation of oxygen reduction kinetics (ORR). No suppression effect for oxygen reduction was observed for bare platinum in the solution containing impurity ions, indicating that the effect is specific to the metal electrode-ionomer membrane interface. ${ }^{10}$ This may lead not only to the kinetic degradation of ORR, but also to detachment of the catalyst/ionomer contact. A contaminant level as low as $1 \%$ will be enough to hinder enormously the rate of charge-transfer step at platinum covered with perfluoro-sulfonated ionomer. ${ }^{10}$

Major amount of research on cation contamination has been conducted by modeling and ex-situ immersion of fuel cell components in cationic impurities. Comparatively, little research has been carried on in-situ or real world cation contamination on fuel cell. As an example, fuel system is open to the ambient atmosphere and air is used as a fuel. Fuel cell is susceptible to performance degradation by contaminant ingress. So studying cation contamination in in-situ condition is increasingly important for commercialization of fuel cell. Understanding the impact, mechanism and recovery methodologies will help to design filters for air/hydrogen as well as improve durability of the fuel cell. 


\subsection{Cation Contaminant selection}

It is not possible to investigate all the cation contaminants in a single study. Therefore, it is necessary to select suitable contaminants and ion selection is based on several levels of screening.

\section{Periodic table}

Initial selection was based on the periodic table. A number of these elements were dropped due to the fact they are not encountered in nature. An additional number of these elements were dropped due to the phase state when encountered in nature. This down selection resulted in about 18 elements to consider:

$\mathrm{Ag}, \mathrm{Al}, \mathrm{Ba}, \mathrm{Be}, \mathrm{Ca}, \mathrm{Ce}, \mathrm{Co}, \mathrm{Cr}, \mathrm{Cu}, \mathrm{Fe}, \mathrm{K}, \mathrm{Mg}, \mathrm{Mn}, \mathrm{Na}, \mathrm{Ni}, \mathrm{Ti}, \mathrm{V}, \mathrm{Zn}$.

\section{Worldwide air and water filter samples}

The initial element pool was further reduced be analyzing samples taken at various points around the world. Some of the samples were extracted from alternate activities. The samples run the gauntlet from air and water filters supplied by industry partners from various development programs.

The study has samples from the west coast (Oakland, CA, USA), the mid-west (Minneapolis, MN, USA), the east coast (Billerica, MA, USA), and Asia (South Korea). Six different filters were collected and samples from each filter are analyzed using SEM and EDX. Due to the variability of pore size of the filters, smaller particles may not have been adequately trapped in some of the filters.

Fig. 1.3 and Fig. 1.4 shows two different types of Donaldson's Fuel Cell Contamination Control (FC3) filters (FCX400131) (Donaldson Company, Minneapolis, MN, USA) and SEM/EDX analyses. These filters are designed specifically for fuel cell 
cathode air contamination control applications. ${ }^{44}$ From the elemental analysis of the cylindrical filter shown in Fig. 1.3b, various impurities are found including $\mathrm{Na}, \mathrm{K}, \mathrm{Ca}$, $\mathrm{Mg}, \mathrm{Fe}$, and Al. Similar kind of cationic impurities are found from the elemental analysis of both side of the rectangular filter shown in Fig. 1.4.

Fig. 1.5a shows a filter from Nuvera fuel cells Inc. (Billerica, MA, USA) and SEM/EDX analyses of the surface of the filter and dust on the filter are shown in Fig. 1.5b-c. It contains various impurities including $\mathrm{Na}, \mathrm{K}, \mathrm{Ca}, \mathrm{Mg}, \mathrm{Fe}$, and $\mathrm{Al}$.

Fig. 1.6 and Fig. 1.7 show the two filters from Oakland, California, USA. These filters are from fuel cell bus made by (formerly known as) UTC Power based in South Windsor, CT, USA. Fig. 1.6a shows cylindrical filter which contains impurities including $\mathrm{Na}, \mathrm{K}, \mathrm{Ca}, \mathrm{Mg}, \mathrm{Fe}$, and Al. Fig. 1.7a shows a rectangular filter which contains $\mathrm{Na}, \mathrm{Ca}$, $\mathrm{Mg}$, $\mathrm{Al}$, etc. Last filter was from Korea. It is shown in Fig. 1.8a. It contains $\mathrm{Al}$ and $\mathrm{Ca}$ impurities.

In all six filters, two metallic impurities are common: $\mathrm{Ca}$ and $\mathrm{Al}$. Other than metal, all filters except Korean filter contains $\mathrm{Cl}$. So list of metal ions found in the filters are:

$\mathrm{Na}, \mathrm{K}, \mathrm{Ca}, \mathrm{Mg}, \mathrm{Fe}$, and $\mathrm{Al}$

\section{Most likely to encounter based on usage and probable future usage}

$\mathrm{Fe}^{+2}, \mathrm{Fe}^{+3}, \mathrm{Cr}^{+3}, \mathrm{Ni}^{+2}$ are common ions for carbon and stainless steels. These materials are often used in the construction of fuel cell systems. ${ }^{45,46}$ 


\section{Solubility and Availability}

The solubility of various solutions is listed in Table 1.2. This information indicated that testing phosphates, carbonates and titanium ions will be a challenge and might best be avoided.

\section{Availability of data}

A number of elements have already been studied. Additional data on these elements would be of less value then elements not previously studied.

\section{Screening tests}

We experimentally investigated nine different cations $\left(\mathrm{Na}^{+}, \mathrm{K}^{+}, \mathrm{Mg}^{2+}, \mathrm{Ca}^{2+}, \mathrm{Ni}^{2+}\right.$, $\left.\mathrm{Ba}^{2+}, \mathrm{Al}^{3+}, \mathrm{Cr}^{3+}, \mathrm{Fe}^{3+}\right)$ with a combination of five different anions $\left((\mathrm{Cl})^{-},(\mathrm{OH})^{-},\left(\mathrm{ClO}_{4}\right)^{-}\right.$, $\left.\left(\mathrm{CO}_{3}\right)^{2-},\left(\mathrm{SO}_{4}\right)^{2-}\right)$ being injected directly into the air stream of an operating fuel cell.

\section{One Cation for detailed study}

After considering all the factors mentioned above $\mathrm{Ca}^{2+}$ is selected for detailed study.

- One of two metals that found in all the filters

- A component of road salt, de-icer

- Higher valence and not well studied

- $5^{\text {th }}$ most abundant dissolved ion in seawater by both molarity and mass

$\mathrm{CaSO}_{4}$ salt is selected to make cation solution because it has sufficient water solubility, $2.05 \mathrm{~g} / \mathrm{L}$ water@ $25^{\circ} \mathrm{C}$, and it is a common laboratory and industry chemical.

\subsection{Overall objectives and scope}

In this work, the experimental and theoretical study of the effects of key cathode side cation contaminants on the performance of PEFCs were investigated, and the 
understanding of contamination mechanism was utilized to develop novel technologies for mitigating the effects of contamination.

In chapter 2, some of the screening test results are presented. Simultaneous effect of various cations $\left(\mathrm{Al}^{3+}, \mathrm{Fe}^{3+}, \mathrm{Cr}^{3+}, \mathrm{Ni}^{2+}, \mathrm{Mg}^{2+}\right)$ and chloride anion $\left(\mathrm{Cl}^{-}\right)$was studied by separately introducing $\mathrm{HCl}$ and five different chloride salts in the air stream with constant operating conditions. This work is reported in ECS Trans., 58 (1) 543 (2013) and J. Electrochem. Soc., 162, F373 (2015).

In chapter 3, a steady-state, one dimensional computational model is developed to predict the effect of foreign cation contamination in PEFCs. The model solves the coupled transport phenomena of cations, oxygen, hydrogen, and water. The studies in this chapter are reported in J. Electrochem. Soc., 61, F1081 (2014) and ECS Trans, 64 (3), 705 (2014).

In chapter 4, distributed effects of cation contamination cathode to anode direction in PEFCs were investigated at a fixed concentration of $5 \mathrm{ppm}$ of $\mathrm{Ca}^{2+}$ in the air stream of an operating fuel cell. A special purpose membrane electrode assembly (MEA) was prepared using five layers of membrane, and four Pt wires (electrodes) were inserted between the membrane layers. These Pt electrodes were used to monitor the through plane potential due to the permeation of hydrogen and oxygen from the anode and the cathode, respectively as well as the resistance distribution across the membrane thickness. This study is reported in the literature in ECS Trans., 61 (12), 37 (2014) and Int. J. Hydrogen Energy, 40, 13099, (2015).

In chapter 5, distributed performance of a PEFC is studied using a segmented cell both in galvanostatic and potentiostatic mode during in-situ injection of $\mathrm{Ca}^{2+}$ in the air 
stream. The results are reported in ECS Trans., 61 (12), 49 (2014) and J. Power Source, 296, 64 (2015).

In chapter 6, the effect of cationic contamination in PEFC during long-term test is investigated by contaminating a catalyst coated membrane $(\mathrm{CCM})$ in $\mathrm{Ca}^{2+}$ solution prior to the cell assembly. Part of this work is reported in ECS Trans., 66 (24), 29 (2015).

In chapter 7, the role of gas diffusion layer (GDL) in cationic contamination and recovery from cationic impurities is studied by simulating the cationic contamination with equilibrium uptake of the membrane electrode assembly (MEA) in $\mathrm{Ca}^{2+}$ solution. To contaminate MEA with a cationic solution, three methods were used with the major difference being whether the CCM was completely/partially exposed to the cationic solution or separated by the GDL and gasket. Part of this work is reported in ECS Trans., $64(3), 537$ (2014).

Finally, in chapter 8 , the main findings and conclusions are summarized and future works are outlined. 


\subsection{References}

1. Climate change 2014 Synthesis Report, IPCC fifth assessment synthesis report, 1 November 2014 http://www.ipcc.ch/

2. W. R. Grove, Phil. Mag. and J. Sci. Series 3, 21, 417, (1842).

3. C. Borgnakke and R. E. Sonntag, Fundamentals of Thermodynamics, John Wiley \& Sons (2012).

4. USDRIVE Fuel Cell Tech Team Roadmap, 2013 www.vehicles.energy.gov/about/partnerships/usdrive.html

5. M. M. Mench, Fuel cell engines, John Wiley \& Sons (2008).

6. B. Verspagen, Advan. Com. Sys., 10, 93 (2006).

7. N. H. Jalani and R. Datta, J. Membr. Sci., 264, 167 (2005).

8. Multi-Year Research, Development and Demonstration Plan, 2013 http://energy.gov/eere/fuelcells/fuel-cell-technologies-office-multi-year-researchdevelopment-and-demonstration-plan

9. R. Borup, J. Meyers, B. Pivovar, Y.S. Kim, R. Mukundan, N. Garland, D. Myers, M. Wilson, F. Garzon, D. Wood, Chem. Rev., 107 (2007) 3904-3951.

10. T. Okada, in Handbook of fuel cells - Fundamentals, Technology and Applications, W. Vielstich, H. A. Gasteiger, A. Lamm, and H. Yokokawa, Editors, John Wiley \& Sons, Ltd, (2010).

11. A. Collier, H. Wang, X. Z. Yuan, J. Zhang and D. P. Wilkinson, Int. J. Hydrogen Energy, 31, 1838 (2006).

12. X. Cheng, Z. Shi, N. Glass, L. Zhang, J. Zhang, D. Song, Z. Liu, H. Wang and J. Shen, J. Power Sources, 165, 739 (2007).

13. M. P. Rodgers, L. J. Bonville, H. R. Kunz, D. K. Slattery and J. M. Fenton, Chem. Rev., 112, 6075 (2012).

14. T. Okada, J. Electroanal. Chem., 465, 1 (1999).

15. T. Okada, J. Electroanal. Chem., 465, 18 (1999).

16. B. Kienitz, H. Baskaran, T. Zawodzinski and B. Pivovar, ECS Trans., 11(1), 777 (2007).

17. B. Kienitz, H. Baskaran and T. Zawodzinski, Electrochim. Acta., 54, 1671 (2009).

18. M. F. Serincan, U. Pasaogullari and T. Molter, Int. J. Hydrogen Energy., 35, 5539 (2010).

19. J. St-Pierre, Int. J. Hydrogen Energy., 36, 5527 (2011).

20. M. A. Uddin and U. Pasaogullari, J. Electrochem. Soc., 161, F1081 (2014).

21. H. Yeager and A. Steck, J. Electrochem. Soc., 128, 1880 (1981).

22. T. Okada, N. Nakamura, M. Yuasa and I. Sekine, J. Electrochem. Soc., 144, 2744 (1997).

23. T. Okada, G. Xie, O. Gorseth, S. Kjelstrup, N. Nakamura and T. Arimura, Electrochim. Acta, 43, 3741 (1998).

24. T. Okada, S. Møller-Holst, O. Gorseth and S. Kjelstrup, J. Electroanal. Chem., 442, 137 (1998).

25. T. Okada, Y. Ayato, M. Yuasa and I. Sekine, J. Phy. Chem. B, 103, 3315 (1999).

26. M. Saito, N. Arimura, K. Hayamizu and T. Okada, J. Phy. Chem. B., 108, 16064 (2004). 
27. A. Pozio, R. Silva, M. De Francesco and L. Giorgi, Electrochim. Acta., 48, 1543 (2003).

28. M. J. Kelly, G. Fafilek, J. O. Besenhard, H. Kronberger and G. E. Nauer, J. Power Sources, 145, 249 (2005).

29. H. Li, K. Tsay, H. Wang, J. Shen, S. Wu, J. Zhang, N. Jia, S. Wessel, R. Abouatallah and N. Joos, J. Power Sources, 195, 8089 (2010).

30. B. Kienitz, B. Pivovar, T. Zawodzinski and F. H. Garzon, J. Electrochem. Soc., 158, B1175 (2011).

31. M. Sulek, J. Adams, S. Kaberline, M. Ricketts and J. R. Waldecker, J. Power Sources, 196, 8967 (2011).

32. J. Qi, X. Wang, U. Pasaogullari, L. Bonville and T. Molter, J. Electrochem. Soc., 160, F916 (2013).

33. X. Wang, J. Qi, O. Ozdemir, A. Uddin, U. Pasaogullari, L. J. Bonville and T. Molter, J. Electrochem. Soc., 161, F1006 (2014).

34. M. A. Uddin, X. Wang, M. O. Ozdemir, J. Qi, L. J. Bonville, U. Pasaogullari and T. Molter, ECS Trans., 61(12, 49 (2014).

35. M. A. Uddin, J. Qi, X. Wang, M. O. Ozdemir, N. K. H. Dalasm, L. J. Bonville, U. Pasaogullari and T. Molter, ECS Trans., 61(12), 37 (2014).

36. M. A. Uddin, J. Park, X. Wang, J. Qi, U. Pasaogullari, L. J. Bonville and T. Molter, ECS Trans., 64(3), 537 (2014).

37. M. A. Uddin, X. Wang, J. Qi, M. O. Ozdemir, U. Pasaogullari, L. Bonville and T. Molter, J. Electrochem. Soc., 162, F373 (2015).

38. J. Qi, X. Wang, M. O. Ozdemir, M. A. Uddin, L. Bonville, U. Pasaogullari and T. Molter, J. Power Sources, 286, 18 (2015).

39. 31. M. J. Kelly, B. Egger, G. Fafilek, J. O. Besenhard, H. Kronberger and G. E. Nauer, Solid State Ionics, 176, 2111 (2005).

40. H. Wang and J. A. Turner, J. Power Sources, 183, 576 (2008).

41. K. Hongsirikarn, J. G. Goodwin, S. Greenway and S. Creager, J. Power Sources, 195, 7213 (2010).

42. T. Okada, Y. Ayato, H. Satou, M. Yuasa and I. Sekine, J. Phy. Chem. B, 105, 6980 (2001).

43. T. E. Springe, T. A. Zawodzinski and S. Gottesfeld, J. Electrochem. Soc., 138, 2334 (1991).

44. Donaldson air filter media specifically for fuel cell air inlets, Fuel Cells Bulletin, 2005, 5 (2005) doi:10.1016/S1464-2859(05)70707-0.

45. ASTM A106, Standard Specification for Seamless Carbon Steel Pipe for HighTemperature Service.

46. ASTM A213, Standard Specification for Seamless Ferritic and Austenitic Alloy-Steel Boiler, Superheater, and Heat-Exchanger Tubes.

47. D. R. Lide, CRC Handbook of Chemistry and Physics 2006-2007: A Ready-Reference Book of Chemical and Physical Data, CRC press, Florida (2006). 


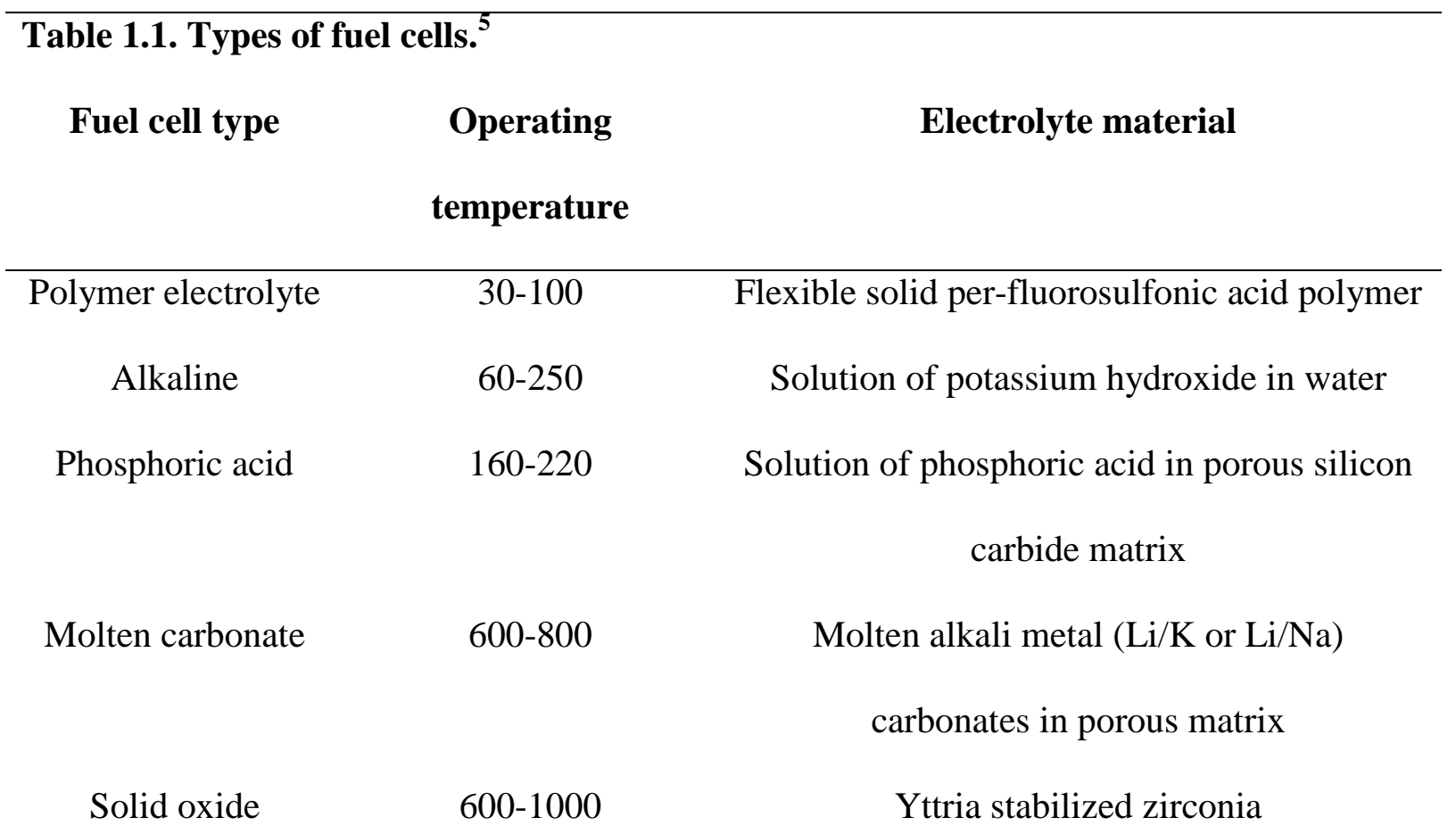




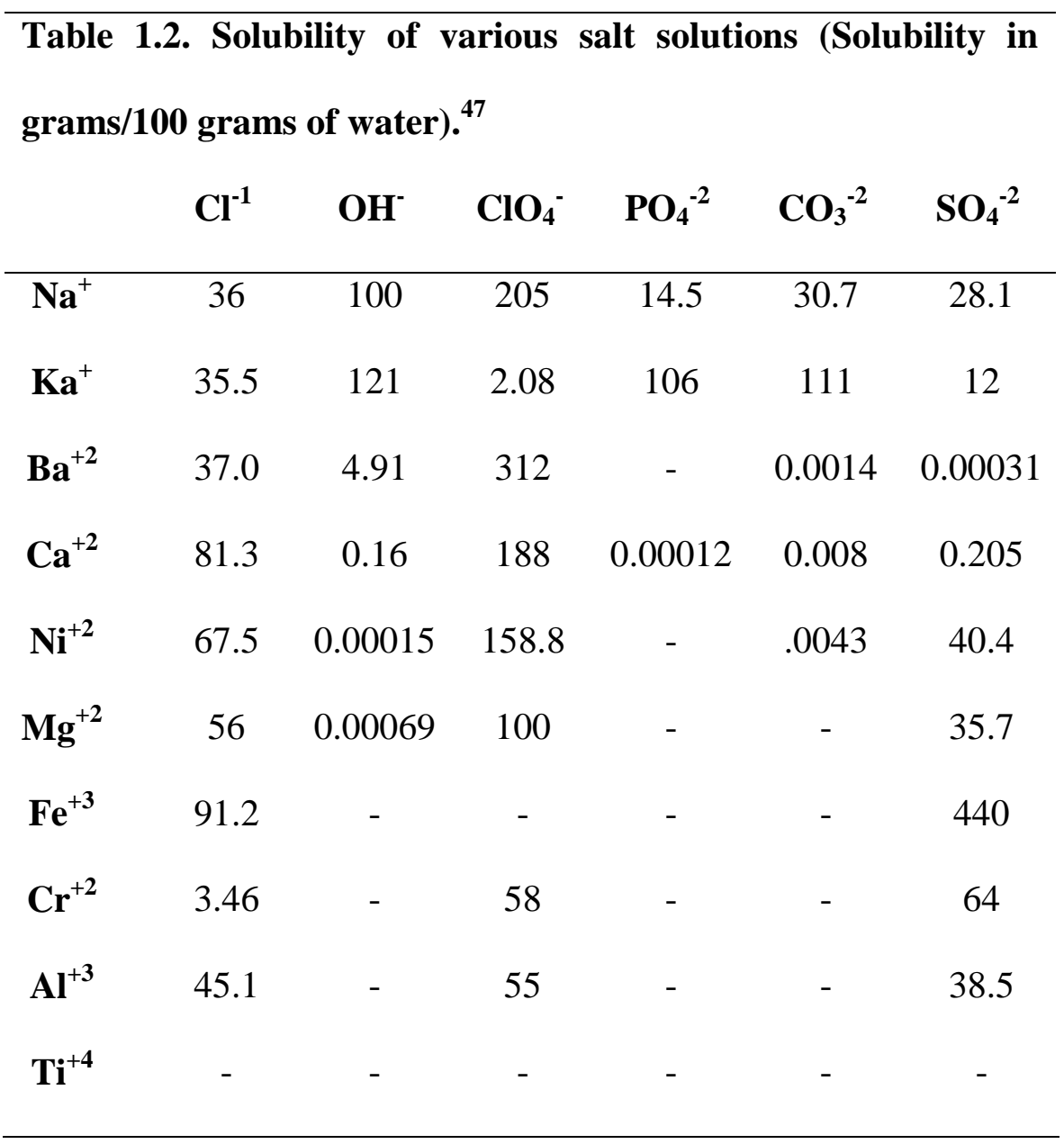




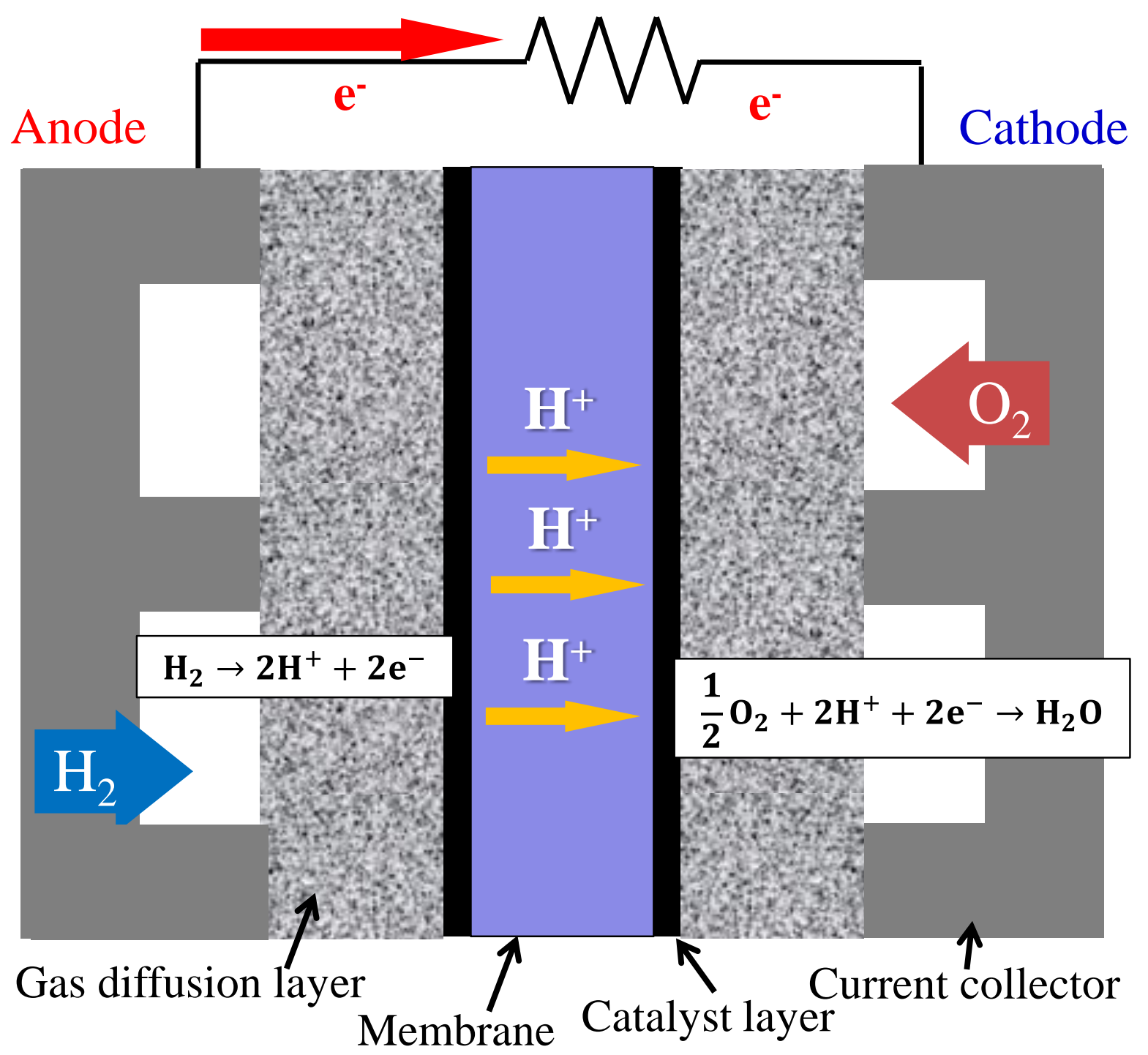

Fig. 1.1. Schematics of a polymer electrolyte fuel cell (PEFC). 


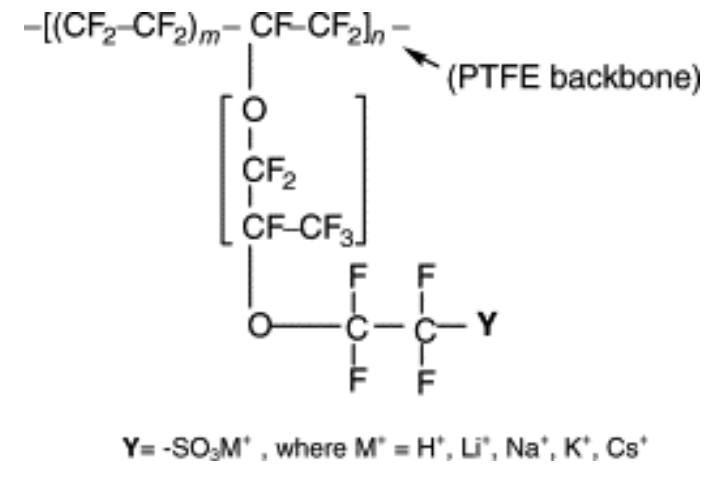

Fig. 1.2. Structural details of Nafion ${ }^{\circledR}$ membrane. ${ }^{7}$ Figure used with permission from Elsevier. 
(a)
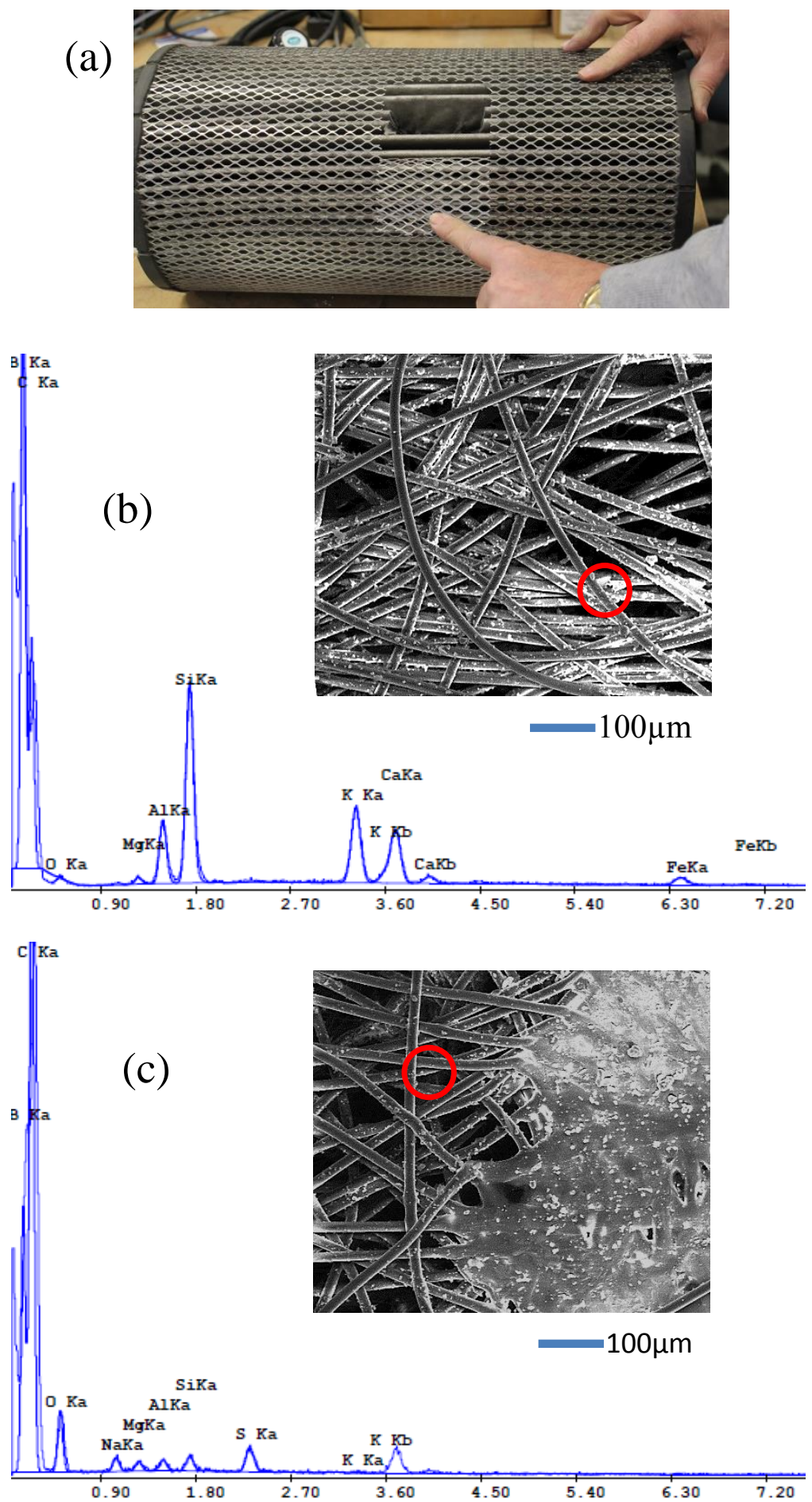

Fig. 1.3. (a) Donaldson's Fuel Cell Contamination Control (FC3) filter (FCX400131), (b) SEM and EDX of the filter, and SEM and EDX of dust on the filter. 


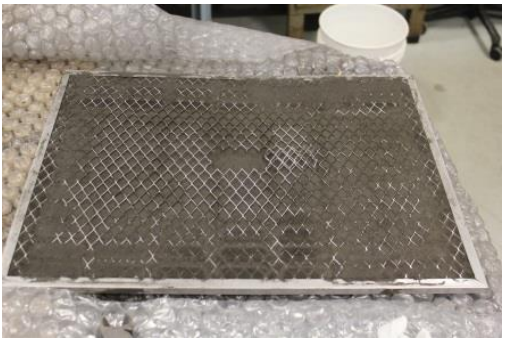

(a)

(c)

(d)

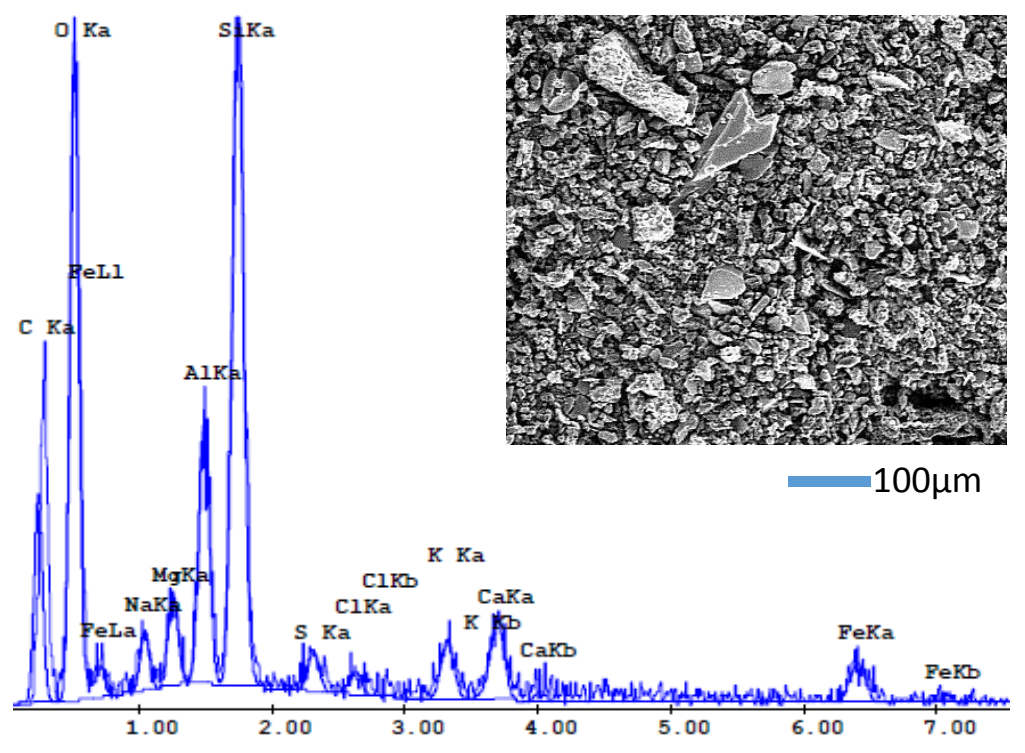

(b)

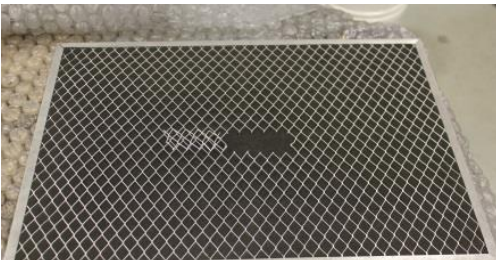

)

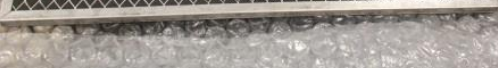

(d)
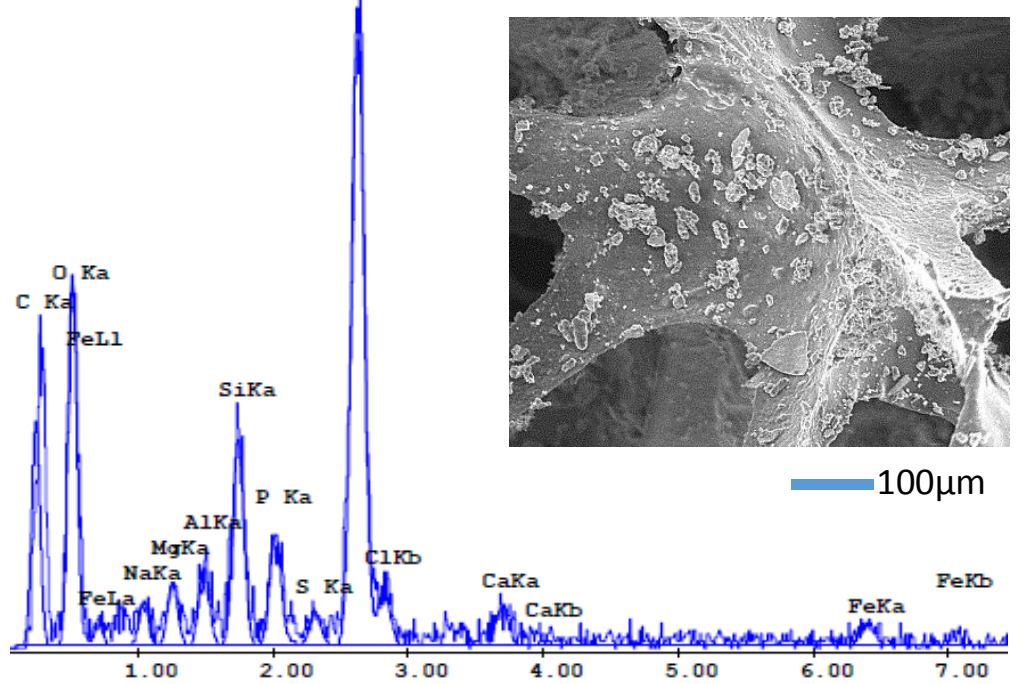

Fig. 1.4. Donaldson's Fuel Cell Contamination Control (FC3) filter (FCX400131) (a) outside, (b) inside, (c) SEM and EDX of outside of the filter, and (d) SEM and EDX of inside of the filter. 
(a)
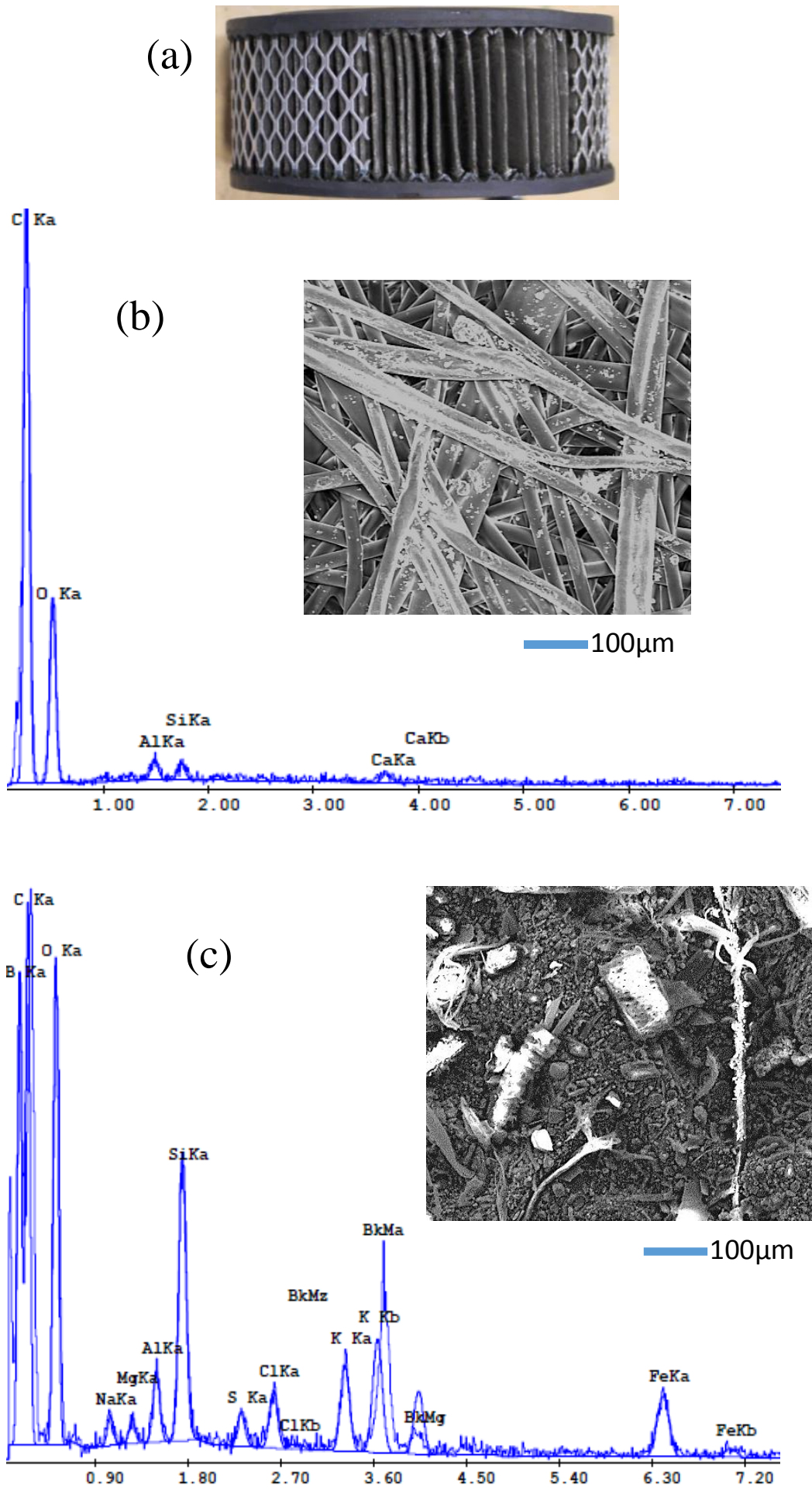

Fig. 1.5. (a) Filter from Nuvera Fuel Cell Inc., (b) SEM and EDX of the filter, and (c) SEM and EDX of dust on the filter. 

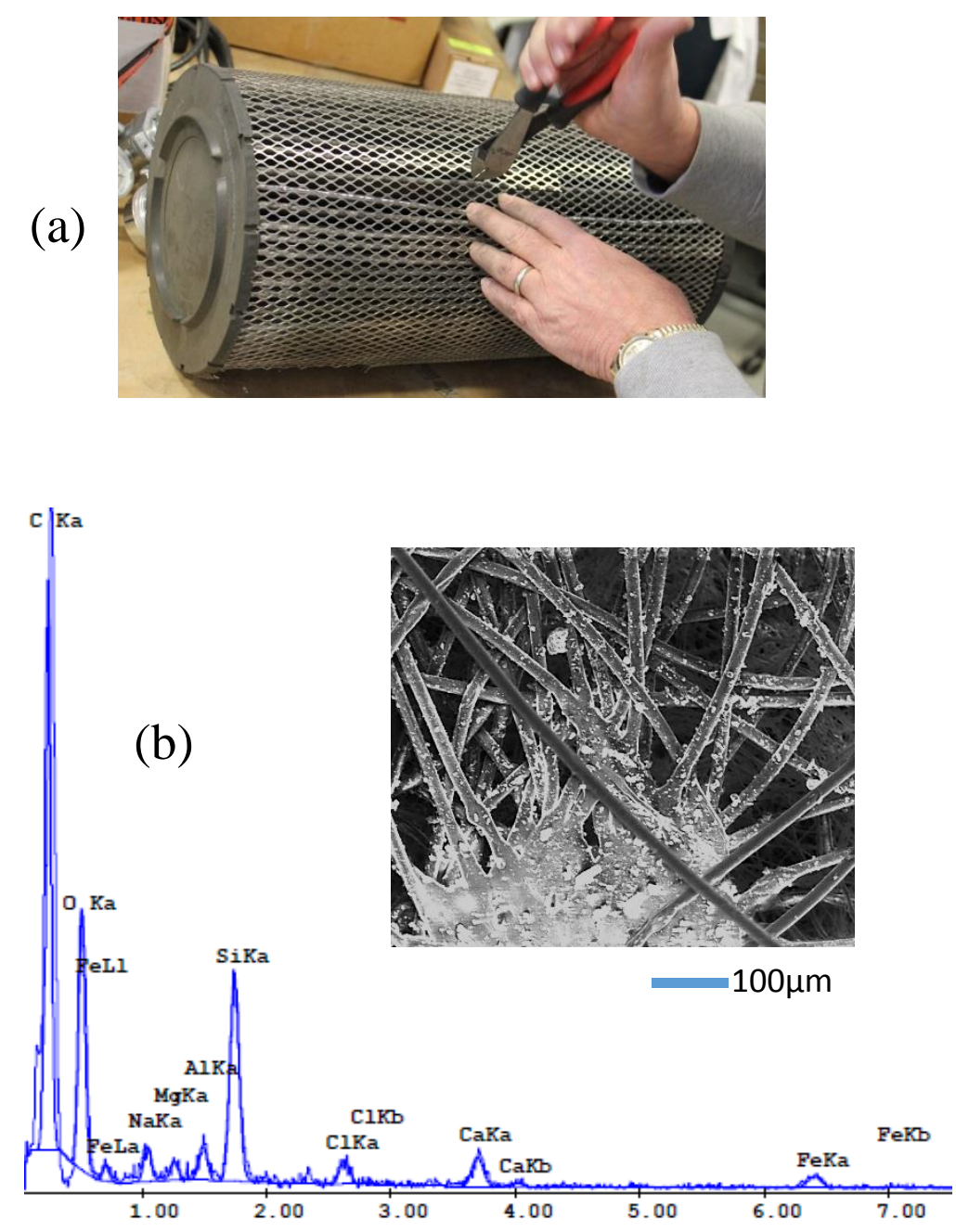

Fig. 1.6. (a) UTC power cylindrical filter (from Oakland, CA, USA) and (b) SEM and EDX of the filter. 

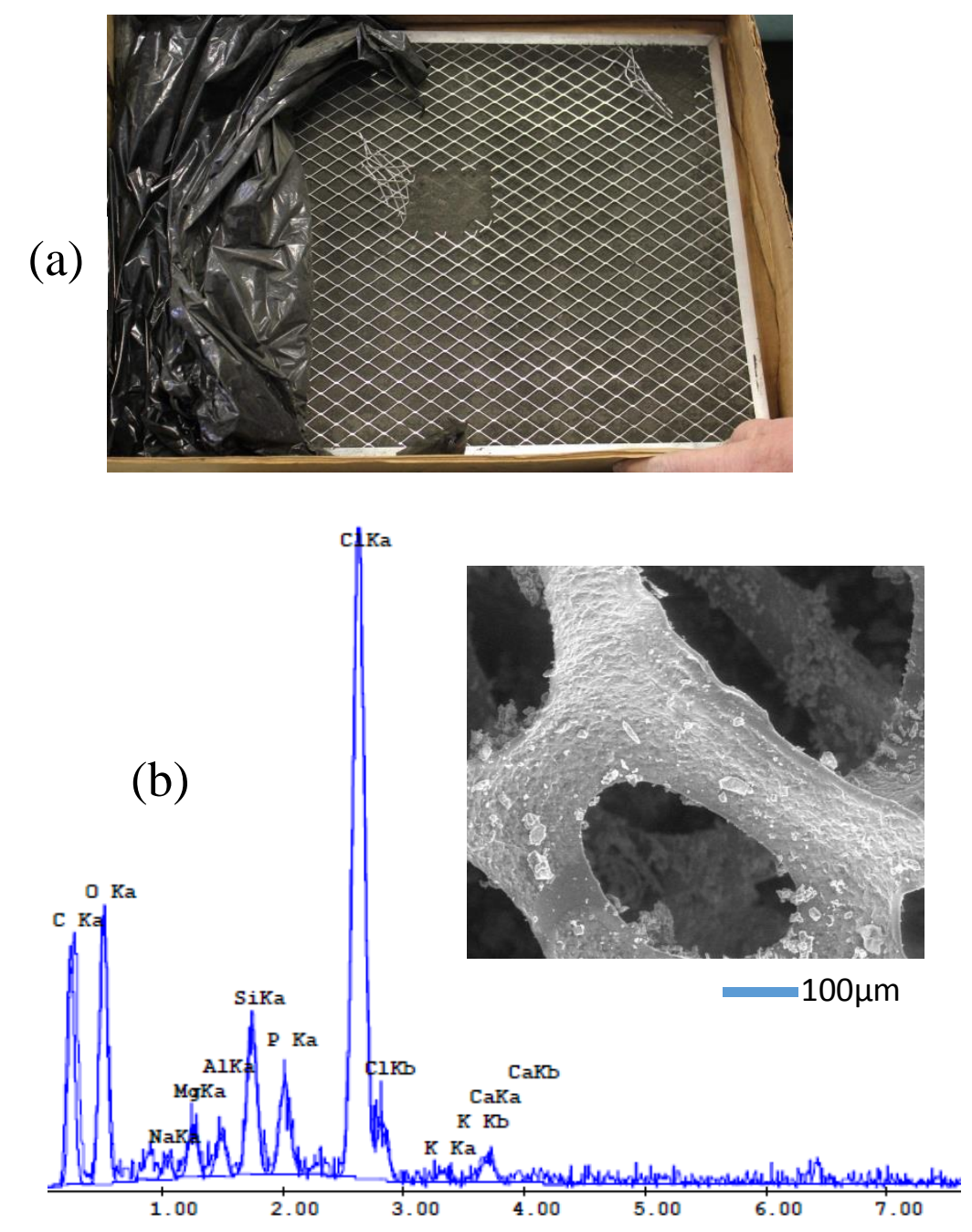

Fig. 1.7. (a) UTC power cylindrical filter (from Oakland, CA, USA) and (b) SEM and EDX of the filter. 
(a)
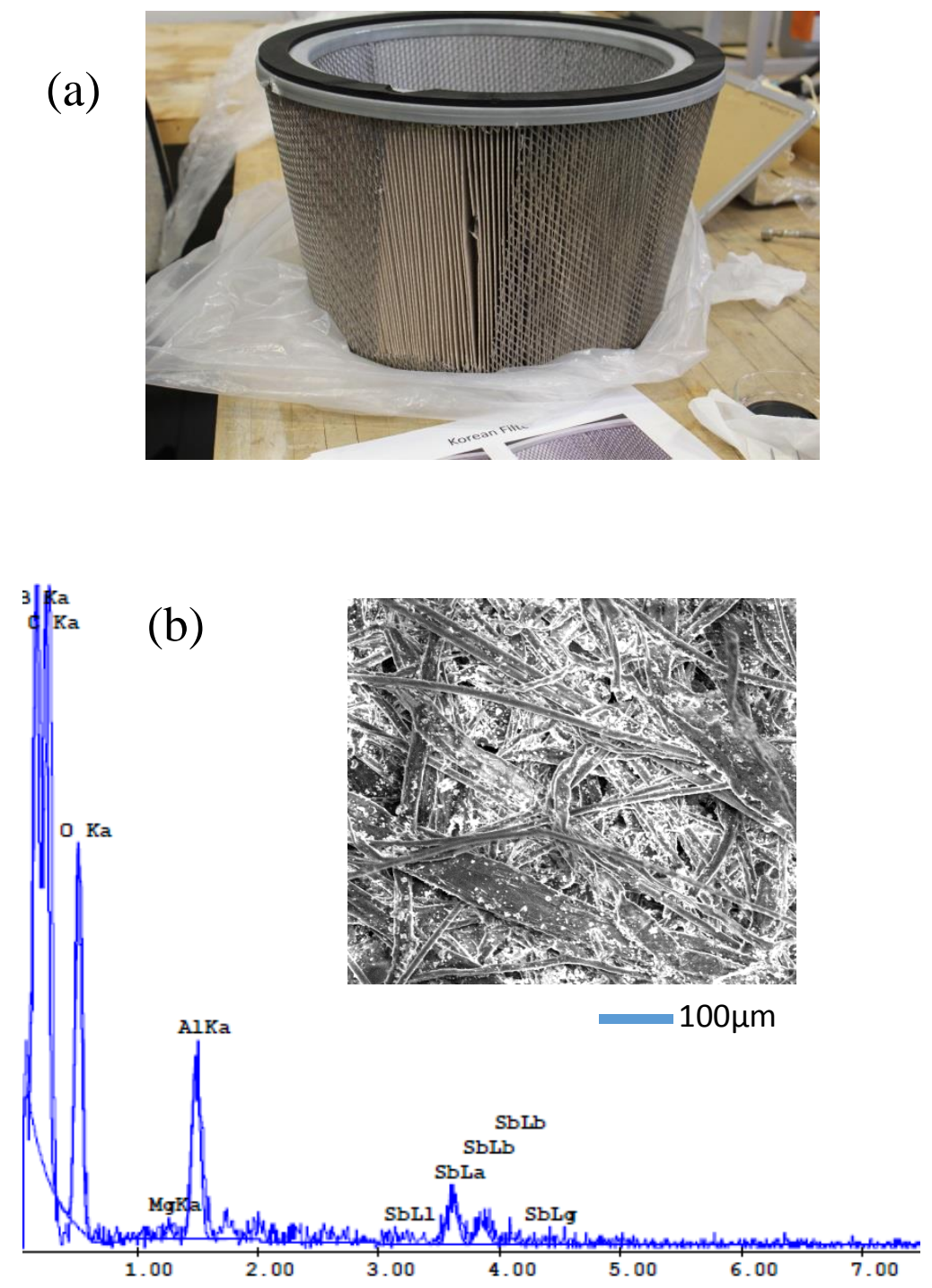

Fig. 1.8. (a) Korean filter and (b) SEM and EDX of Korean filter. 


\section{EFFECT OF CHLORIDE ON POLYMER}

\section{ELECTROLYTE FUEL CELLS IN PRESENCE OF}

\section{VARIOUS CATIONS}

\subsection{Introduction}

Impurities present in fuel and air have a severe effect on durability and performance of PEFCs. Impurities may be introduced into the fuel cell from the fuel and air stream or from the corrosion of fuel cell stack and system components, such as bipolar plates, seals, inlet/outlet manifolds, humidifier reservoirs, and cooling loops. ${ }^{1,2}$ Chloride $\left(\mathrm{Cl}^{-}\right)$is a contaminant, which can enter through air or fuel stream in various forms. It is commonly present in air near marine environments, and it is also present as a deicer on roads during the winter. ${ }^{3}$ In addition, Pt-based catalysts are often synthesized from chloride-containing precursors and trace amount of chloride may remain after synthesis. ${ }^{4}$ Moreover, to reduce hydrogen production and transportation costs, the direct use of waste or byproduct hydrogen from chemical plants (e.g., in the chlor-alkali industry) can also introduce chloride in fuel stream. ${ }^{5}$

Several ex-situ ${ }^{4,6,7}$ and in-situ studies ${ }^{3,5,8-13}$ have been carried out to understand the effects of chloride contamination. Schmidt et al. found that the presence of chloride on the Pt surface mainly acted as a site blocking species and reduced the number of active sites for the ORR. ${ }^{4}$ It also enhanced the formation of $\mathrm{H}_{2} \mathrm{O}_{2}$. Further, chloride promoted the dissolution of Pt by the formation of soluble chloride complexes near the inlet portion of the MEA and then deposited in the membrane. ${ }^{13}$ Yadav et al. found a chloride ion 
concentration of as low as $10 \mathrm{ppm}$ can induce Pt dissolution as chloride complexes with the following reactions at $1.06 \mathrm{~V} .^{6}$

$$
\begin{aligned}
& \mathrm{Pt}+4 \mathrm{Cl}^{-}=\left[\mathrm{PtCl}_{4}\right]^{2-}+2 \mathrm{e}^{-} \\
& \mathrm{Pt}+6 \mathrm{Cl}^{-}=\left[\mathrm{PtCl}_{6}\right]^{2-}+4 \mathrm{e}^{-}
\end{aligned}
$$

$\mathrm{Li}$ et al. conducted tests by injecting several ppm concentration of $\mathrm{HCl}$ as the contaminant into the fuel cell from both the fuel stream and the air stream. ${ }^{5,10}$ They concluded that it did not matter whether chloride was injected in fuel or air side, chloride contamination was ultimately a cathode effect, and after chloride injection, cell voltage dropped suddenly which was followed by a stable performance. ${ }^{5}$ The effect of chloride contamination increased with increase in current density and chloride concentration. Low relative humidity $(\mathrm{RH})$ also increased the severity of contamination effect. ${ }^{10}$ Baturina et al. investigated the performance degradation by introducing $\mathrm{HCl}^{8}$ and $\mathrm{NaCl}^{9}$ aerosol in the air stream. They did not find any significant performance degradation for $\mathrm{NaCl}$ aerosol, while large performance degradation was observed for $4 \mathrm{ppm} \mathrm{HCl}$. They concluded that $\mathrm{HCl}$ passed through the GDL to reach the surface of Pt catalyst, while $\mathrm{NaCl}$ aerosol could not cross the hydrophobic surface of the GDL. So, cell performance was not affected by $\mathrm{NaCl}$ aerosol. Yan et al. found that calcium chloride $\left(\mathrm{CaCl}_{2}\right)$ affects the cell performance more than sodium chloride $(\mathrm{NaCl})$ when these impurities were present in the air stream. ${ }^{12}$ But they did not distinguish the individual effect of chloride and cations. Other researchers also found significant decrease in fuel cell performance due to chloride contamination. ${ }^{3,11}$

Along with chloride poisoning, foreign cations themselves can cause severe degradation. ${ }^{2,14-16}$ Foreign cations typically have higher affinity to the sulfonic acid group 
than protons, and the presence of foreign cations in the membrane decreases water content and consequently the ionic conductivity of the membrane. ${ }^{14}$ Pozio et al. investigated Nafion ${ }^{\circledR}$ degradation in polymer electrolyte fuel cells caused by iron contamination from SS316L end plates in a single cell configuration. ${ }^{15}$ They stated that contamination of membrane electrode assemblies with iron led to degradation of the ionomer, revealed by a massive fluoride loss. Li et al. reported that a level of only 5 ppm of $\mathrm{Fe}^{3+}$ and $\mathrm{Al}^{3+}$ in air stream caused significant cell performance degradation. ${ }^{2}$ They also reported that $\mathrm{Al}^{3+}$ reduced ORR kinetics and changed the ORR mechanism from a more 4-electron pathway towards a more 2-electron pathway. Sulek et al. tested fuel cells with membrane immersed with four metal $\left(\mathrm{Al}, \mathrm{Fe}, \mathrm{Ni}\right.$, and $\mathrm{Cr}$ ) sulfate $\left(\mathrm{SO}_{4}\right)^{2-}$ solutions. ${ }^{16}$ Performance degradation ranking for those metal ions was found to be: $\mathrm{Al}^{3+}>>\mathrm{Fe}^{2+}>$ $\mathrm{Cr}^{2+}, \mathrm{Ni}^{2+}$

Our group have investigated the effect of different cations $\left(\mathrm{K}^{+}, \mathrm{Ca}^{2+}, \mathrm{Ba}^{2+}, \mathrm{Al}^{3+}\right)$ on PEFCs through experimenting with a combination of different anions $\left(\left(\mathrm{ClO}_{4}\right)^{-}\right.$and $\left.\left(\mathrm{SO}_{4}\right)^{2-}\right)$ being injected directly into the air stream of an operating fuel cell ${ }^{17-23}$, as well as modeling the effects of cationic contamination on PEFC performance. ${ }^{24,25}$ We observed that water management significantly affects contamination by cations, which may result in salt precipitation causing serious mass transport losses. ${ }^{18-25}$ In this chapter, simultaneous effect of various cations $\left(\mathrm{Al}^{3+}, \mathrm{Fe}^{3+}, \mathrm{Cr}^{3+}, \mathrm{Ni}^{2+}, \mathrm{Mg}^{2+}\right)$ and chloride anion $\left(\mathrm{Cl}^{-}\right)$was studied by separately introducing $\mathrm{HCl}$ and five different chloride salts in the air stream with constant operating conditions. 


\subsection{Experimental}

\subsubsection{Experimental setup}

A fuel cell test station (Teledyne MEDUSA RD, TELEDYNE Energy Systems, Inc., Hunt Valley, MD) interfaced with a Scribner 890C load box (Scribner Associates Inc. Southern Pines, NC) was employed for the test. A set of single-cell hardware (Fuel Cell Technology, Albuquerque, NM, USA) was used for each test. The hardware consisted of two machined graphite flow fields, two aluminum end plates and two goldplated current collectors. The graphite flow fields had single serpentine and triple serpentine flow channels on the anode and the cathode side, respectively, with $1.0 \mathrm{~mm}$ width, $1.0 \mathrm{~mm}$ depth and $1.0 \mathrm{~mm}$ lands. The MEA was prepared with a catalyst coated membrane (CCM) $\left(\right.$ Gore $^{\mathrm{TM}}$ PRIMEA $^{\circledR}$, W.L. Gore\& Associates Inc., Elkton, MD) and two SGL 25BC (Ion Power, Inc., New Castle, DE) gas diffusion layers (GDL). The active area of the MEA was $25-\mathrm{cm}^{2}$ and Pt loading on the anode and the cathode catalyst layers was 0.1 and $0.4 \mathrm{mg} / \mathrm{cm}^{2}$, respectively. The contaminant injection system consisted of a micro flow nebulizer (ES-2005, PFA-400, Elemental Scientific Inc., Omaha, NE USA) and a high-resolution micro pump (Series III Pump, Scientific Systems Inc., State College, PA). The nebulizer was used to introduce finely dispersed contaminant solution into air stream. It was placed just prior to the cathode inlet (shown in the Fig. 2.1).

\subsubsection{Contaminants and operating conditions}

Hydrogen chloride and five different chloride salts $\left(99.99 \%\right.$ pure, ScholAR ${ }^{\circledR}$ Chemistry, St. Louis, MO) were used as contaminants (Table 2.1). For each experiment, the chloride $\left(\mathrm{Cl}^{-}\right)$concentration was maintained at $28.5 \mathrm{mM}$ which corresponds to 50 
ppm of chloride on dry air basis. This concentration (50 ppm) is adopted to accelerate the test and to observe a significant performance loss due to contamination in a reasonable experimental duration. Cell temperature was maintained at $80^{\circ} \mathrm{C}$. For all the cells (cell 1 to cell 6), operating conditions were similar except cell 7 where the cell was run with a lower relative humidity (RH). All the operating conditions are listed in Table 2.2.

\subsubsection{Cell Testing and diagnostic measurement}

Cell testing procedure is explained in details in our previous paper. ${ }^{20}$ In brief, the cell was conditioned using a constant voltage break-in procedure. The cell voltage was set to $0.6 \mathrm{~V}$, and the cell was run overnight until a stable performance was achieved. After cell break-in, polarization curves were measured at $80^{\circ} \mathrm{C}$ with $100 \%\left(\mathrm{H}_{2}\right)$ and $75 \%$ (air) relative humidity and $\mathrm{H}_{2}$ /air flow rate was maintained at 2 stoichiometry with a minimum flow rate of $200 \mathrm{sccm}$. After polarization scans, $\mathrm{H}_{2}$ crossover (XO) and cyclic voltammetry (CV) curves were measured using a potentiostat/galvanostat (Solartron SI 1287). During both $\mathrm{XO}$ and $\mathrm{CV}$ experiments, cathode was purged with $\mathrm{N}_{2}$, while $\mathrm{H}_{2}$ was fed through anode with a flow rate of $250 \mathrm{sccm}$. The cell temperature was set as $80^{\circ} \mathrm{C}$, and $100 \%$ and $75 \%$ relative humidity was maintained at the anode and the cathode, respectively. The XO curves were recorded at a scan rate of $2 \mathrm{mV} / \mathrm{sec}$ over the range of 0.1-0.4 V. The CV curves were recorded at a scan rate of $20 \mathrm{mV} / \mathrm{sec}$ over the range of 0.05-0.8 V. All these operating conditions are used from our predefined baseline for all PEFC tests conducted in our lab.

After the beginning of the test (BOT) diagnostics, a baseline test was conducted without any contaminant for 24 hours. During the baseline test, DI water was injected through nebulizer with a flow rate of $130 \mu \mathrm{L} / \mathrm{min}$. This water was included in the relative 
humidity calculations. Ultra high purity hydrogen (99.999\%, Airgas Inc., Hastings, NE) and zero grade air (99.8\%, Airgas Inc., Hastings, NE) were fed through anode and cathode with a flow rate of $1.75 \mathrm{slpm}$ and $1.66 \mathrm{slpm}$, respectively. After the initial 24 hours baseline test, the cell was operated for 48 hours with contaminant solution injecting through nebulizer. After the contaminant test, the cell was run for another 24 hours with DI water through the nebulizer for the recovery test. During all the stages of the test, the cell was run with a constant current density of $1 \mathrm{~A} / \mathrm{cm}^{2}$ which is predefined from our baseline tests. A high relative humidity was maintained at the cathode (120\%) compared to the anode (25\%) to facilitate contaminant transport in the air stream and to maintain a water concentration gradient for the convective transport of contaminant solution from the cathode to the anode. For the same reason, a high back pressure is maintained at the cathode (15psig) compared to the anode (1.5 psig). Moreover, a high air flow was maintained at the cathode (4 stoichiometry) to carry more water in the cathode that can help to prevent contaminant precipitation and a high hydrogen flow at the anode to ensure enough hydrogen to limit the anode polarization overpotential and to make sure that performance degradation during the tests can be attributed to the contamination. ${ }^{20}$

At the end of the test (EOT), polarization, $\mathrm{XO}$, and $\mathrm{CV}$ measurements were performed again with the operating conditions similar to the beginning of the test measurements for a clear comparison. Then the cell was disassembled and the contaminated CCM and GDL were examined using scanning electron microscope (SEM, FEI ESEM Quanta 250) and energy dispersive X-ray spectroscopy (EDX). The crosssection samples of the CCM/GDL were prepared using a procedure similar to our previous work. ${ }^{17}$ After each test, all the tubing in the test station that was exposed to the 
contaminant was cleaned by flowing DI water. A fresh/virgin MEA was used for each contaminant test.

\subsection{Results and discussion}

\subsubsection{Effects of $\mathrm{HCl}$ and chloride salts}

Fig. 2.2 shows normalized cell voltage and resistance vs. time measured when the cells were tested with $\mathrm{HCl}$ or the various chloride salts $\left(\mathrm{AlCl}_{3}, \mathrm{FeCl}_{3}, \mathrm{CrCl}_{3}, \mathrm{MgCl}_{2}\right.$, and $\mathrm{NiCl}_{2}$ ). The cell resistance was measured by current interrupt which includes the bulk membrane resistance, the GDL electronic resistance, and the contact resistance between fuel cell components. During baseline test (first 24 hours), cell performance was stable for all the tests and the rate of voltage decay was $44 \mu \mathrm{V} /$ hour for the last five hours of the baseline test. The cell voltage was normalized dividing by the average voltage of last five hours (19h to $24 \mathrm{~h}$ ) of the baseline to facilitate easier comparison of all the contaminants. Due to this normalization there was no change happened in the trend of curves. With the start of contaminant injection, the rate of voltage loss increased for all cases. $\mathrm{HCl}$ affected the cell faster than the other contaminants. Significant performance decay was observed for $\mathrm{HCl}$ in less than 24 hours of contamination. Although the chloride $\left(\mathrm{Cl}^{-}\right)$content in air was constant (50 ppm dry air basis) for all the tests, performance losses were not as bad with chloride salts when compared to $\mathrm{HCl}$. The presence of the cation in the contaminant solutions seemed to lessen the effect of $\mathrm{Cl}^{-}$. In fact, there was no measurable performance loss due to the injection of $\mathrm{NiCl}_{2}$ and $\mathrm{MgCl}_{2}$ into the cell. In case of $\mathrm{AlCl}_{3}$, the cell performance was not affected initially, but after 10 hours the cell voltage decreased quickly and approached the $\mathrm{HCl}$ contaminated cell performance after 48 hours. The 
performance curves for $\mathrm{FeCl}_{3}$ and $\mathrm{CrCl}_{3}$ were in between those for $\mathrm{NiCl}_{2}$ and $\mathrm{AlCl}_{3}$. For all the cells, the total voltage loss due to contamination is shown in Fig. 2.3, and the overall performance degradation can be ranked as $\mathrm{HCl}, \mathrm{AlCl}_{3}>\mathrm{FeCl}_{3}>\mathrm{CrCl}_{3}>\mathrm{NiCl}_{2}$, $\mathrm{MgCl}_{2}$. It was observed that the ranking based on initial (first 10h of contamination) decay rate would be different than the ranking based on total voltage drop. $\mathrm{HCl}$ (1.5 $\mathrm{mV} / \mathrm{h})$ and $\mathrm{FeCl}_{3}(1.3 \mathrm{mV} / \mathrm{h})$ had higher initial decay rate compared to other contaminants $\left(\mathrm{AlCl}_{3}\right.$ and $\mathrm{CrCl}_{3}(0.4 \mathrm{mV} / \mathrm{h}), \mathrm{NiCl}_{2}$ and $\left.\mathrm{MgCl}_{2}(0.2 \mathrm{mV} / \mathrm{h})\right)$.

Despite the same operating conditions and at a fixed chloride $\left(\mathrm{Cl}^{-}\right)$concentration of $50 \mathrm{ppm}$, the lower performance loss in presence of various metal ions may result from slower transport of chloride due to presence of metal ions. Chloride salts have much lower solubility in water than $\mathrm{HCl}$ (Table 2.1) and these salts dissociate forming hydrated ions (e.g. $\left.\left[\mathrm{Al}\left(\mathrm{H}_{2} \mathrm{O}\right)_{6}\right]^{3+}\right)$ which may lower the mobility of $\mathrm{Cl}^{-}$. Moreover, metal ion may replace protons in the ionomer of the catalyst layer and lower the transport of $\mathrm{Cl}^{-}$in ionomer similar to the decrease in diffusivity of various gases (hydrogen, nitrogen, and oxygen) ${ }^{28}$ Typically, a thin ionomer film separates the Pt catalyst from the open pores in catalyst layers.

After 48 hours, the cells were put back to uncontaminated air with DI water from the nebulizer to observe the performance recovery. None of the cells exhibited any significant performance recovery. In three stages of our testing, there was no significant change in cell resistance for all the contaminants. It seems there was no change in the membrane resistance due to cation contamination, since other cell components resistance usually remains constant during testing. 
Performance degradation can also be visualized from the polarization curves obtained at BOT and EOT, shown in Fig. 2.4. The operating conditions during the polarization curve measurements are different than during the current hold tests as explained above. For $\mathrm{HCl}, \mathrm{AlCl}_{3}, \mathrm{FeCl}_{3}$, and $\mathrm{CrCl}_{3}$ contaminated cells, performance losses were significant in ohmic, kinetic and mass transport regions. For $\mathrm{MgCl}_{2}$ and $\mathrm{NiCl}_{2}$ contaminated cells, there was no significant change in polarization curves between BOT and EOT. Similar to the constant current tests shown in Fig. 2.2, there was no significant change in cell resistance observed for all the contaminants.

Fig. 2.5 shows cathode cyclic voltammogram (CV) measured at BOT and EOT. $\mathrm{CV}$ of $\mathrm{HCl}$ contaminated cell is shown in Fig. 2.5a. At BOT, hydrogen adsorption and desorption peaks $(0.05$ to $0.35 \mathrm{~V})$ were clearly visible, but at EOT, these peaks were reduced. This was in complete agreement with prior investigations about chloride poisoning ${ }^{4-6}$ and it was caused by the adsorbed chloride $\left(\mathrm{Cl}^{-}\right)$on Pt surface. ${ }^{5,6}$ These absorbed ions $\left(\mathrm{Cl}^{-}\right)$acted as a site blocking agents reducing the active surface area. ${ }^{4}$

The double layer region $(0.35$ to $0.55 \mathrm{~V})$ was widened and $\mathrm{Pt} / \mathrm{PtO}$ redox peak $(0.55$ to $0.8 \mathrm{~V})$ was significantly reduced. Schmidt et al. reported that adsorbed chloride ions caused strong retardation of oxide formation. ${ }^{4}$ The reduced oxide formation decreased Pt oxidation peak in the forward scan as well as Pt reduction peak in the backward scan.

CV curves for $\mathrm{AlCl}_{3}, \mathrm{FeCl}_{3}$ and $\mathrm{CrCl}_{3}$ (Fig. 2.5 b-d) contaminated cells showed similar trend to $\mathrm{HCl}$ contaminated cell. We postulate that $\mathrm{HCl}, \mathrm{AlCl}_{3}, \mathrm{FeCl}_{3}$, and $\mathrm{CrCl}_{3}$ solutions crossed the GDL and reached the active sites and caused the loss of active area as shown in the $\mathrm{CV}$ curves. The $\mathrm{CV}$ curves for $\mathrm{MgCl}_{2}$ and $\mathrm{NiCl}_{2}$ (Fig. $2.5 \mathrm{e}$-f) did not 
change significantly, which were consistent with the performance curves shown in Fig. 2.4(e-f). Although chloride content was constant for all the cells, it is not clear why $\mathrm{MgCl}_{2}$ and $\mathrm{NiCl}_{2}$ did not affect the cell.

Fig. 2.6 shows the SEM image of the CCM surface (cathode side) and corresponding EDX results for a fresh CCM and all the cells tested with chloride contaminants. Significant chloride peak was detected in EDX for the cells tested with $\mathrm{HCl}, \mathrm{AlCl}_{3}, \mathrm{FeCl}_{3}$, and $\mathrm{CrCl}_{3}$ compared to fresh $\mathrm{CCM}$ and. No cations were detected on the CCM surface. We also analyzed GDL surface, GDL cross section, and CCM cross section of all the cells using SEM/EDX. No cations were detected in any of those samples; however they may still be present below the EDX detection limit.

\subsubsection{Effects of relative humidity $(\mathrm{RH})$ on $\mathrm{AlCl}_{3}$ contamination}

Cell 7 with $\mathrm{AlCl}_{3}$ was run with similar operating conditions and contamination level $\left(130 \mu \mathrm{L} / \mathrm{min}\right.$ flow rate of $9.5 \mathrm{mM} \mathrm{AlCl}_{3}$ solution in the air stream which corresponds to $50 \mathrm{ppm} \mathrm{Cl}^{-}$in air) of cell 2, except the cathode relative humidity (RH) was lowered from $120 \%$ to $70 \%$ to check the effect of RH during contamination. Fig. 2.7 shows the cell performance of cell 7 during the current hold at $1 \mathrm{~A} / \mathrm{cm}^{2}$. Similar to Fig. 2.2 , cell voltage was normalized dividing by the average voltage of last five hours $(45 \mathrm{~h}$ to 50h) of the baseline.

During 50 hours of baseline testing, the cell performance was stable. When the cell was exposed to $\mathrm{AlCl}_{3}$, an immediate and sharp voltage drop occurred, and a steady performance throughout the contaminant injection period (50h-98h) was maintained. In contrast, at high RH (120\%) in cathode (cell 2 in Fig. 2.2), cell voltage decreased slowly and continued to decrease until the end of contaminant injection. 
There are couple reasons for this severe effect. Firstly, with lower RH at the contaminant injection side, the water content is decreased. As a result, the concentration of the contaminant increased in the liquid water and thus more chloride reached the catalyst layer where it might be adsorbed on the $\mathrm{Pt}$ surface ${ }^{13}$ and reduce the active area and induce a change in the oxygen reaction mechanism, which is detected by an increase in peroxide formation. ${ }^{4}$ Schmidt et al reported that the fraction of peroxide increases up to $10 \%$ with $1 \mathrm{mM} \mathrm{Cl}^{-}$and $14 \%$ with $10 \mathrm{mM} \mathrm{Cl}^{-}$at $60^{\circ} \mathrm{C}$ and $0.6 \mathrm{~V}$ vs $\mathrm{RHE}^{4}$ Moreover, due to chloride ions adsorption a lengthening of the oxygen transport path on the surface of the Pt might cause mass transport loss. ${ }^{10}$ Secondly, at low RH, salt precipitated on the flow field blocking the flow channels and the cathode GDL surface (Fig. 2.8). In contrast, at high RH (120\%) in cathode, salt did not precipitate in all the other cells (shown in Fig. 2.2) due to high water content.

After $48 \mathrm{~h}$ of contaminant injection, the cell was put back on uncontaminated air and ran the cell until cell performance became stable and a partial recovery of the performance was observed. The partial recovery may partly be due to reversible adsorption of chloride ions on the surface of Pt during contaminant solution injection and the chloride impurities may have been desorbed from the surface of $\mathrm{Pt}$, when the contaminant injection stopped and the cell was run with uncontaminated air. ${ }^{3}$

To identify the deposits on GDL/flow channel, a SEM/EDX analysis was conducted with the GDLs removed after the cell tests were completed. SEM image of GDL surface is shown in Fig. 2.9. It clearly showed the deposit on the GDL. Al and Cl were detected in the elemental spectrum (EDX). This confirms the deposit contained $\mathrm{AlCl}_{3}$, but the $\mathrm{Al}$ and $\mathrm{Cl}$ peak intensity ratio was not 1:3; $\mathrm{Al}$ peak was higher than $\mathrm{Cl}$. 
From the elemental map, it was observed that location of $\mathrm{Al}, \mathrm{Cl}$, and $\mathrm{O}$ matched each other. Therefore, in addition to $\mathrm{Al}$ and $\mathrm{Cl}$, the deposit also contained oxygen $(\mathrm{O})$, therefore we postulate that the salt deposit was most likely a mixture of $\mathrm{AlCl}_{3}$ and $\mathrm{Al}_{2} \mathrm{O}_{3}$. It may also contain aluminum hydroxide $\left(\mathrm{Al}(\mathrm{OH})_{3}\right)$. That might be the reason for higher $\mathrm{Al}$ peak in the EDX compared to 1:3 expected for $\mathrm{AlCl}_{3}$. It was also found that salts were mostly deposited on the surface of the GDL, facing the flow field and some penetrated into the GDL, but did not reach to the membrane side of the GDL (Fig. 2.10). The cross section of CCM was also subjected to SEM/EDX analysis. Similar to all the cells, no cation presence was detected in the membrane.

Polarization curves (Fig. 2.11a) also showed cell performance degradation, indicating losses in all of the kinetic, ohmic, and mass transport regions. Similar to the previous tests, no change in cell resistance observed. CV curves (Fig. 2.11b) also showed significant reduction in hydrogen adsorption and desorption peaks and $\mathrm{Pt} / \mathrm{PtO}$ redox peak, and the ECSA loss was $58 \%$ based on ECSA at BOT. So, the cell performance (shown in Fig. 2.6) did not recover partly due to salt deposit which caused mass transport loss and partly due to ECSA loss increased by contamination.

\subsection{Conclusions}

In this chapter, effect of different cations $\left(\mathrm{Al}^{3+}, \mathrm{Fe}^{3+}, \mathrm{Cr}^{3+}, \mathrm{Ni}^{2+}, \mathrm{Mg}^{2+}\right)$ and an anion $\left(\mathrm{Cl}^{-}\right)$on the performance and durability of PEFCs as air impurity was studied. From the cell performance with constant operating conditions and a constant $50 \mathrm{ppm}$ chloride $\left(\mathrm{Cl}^{-}\right)$content in air stream, it appears that $\mathrm{HCl}$ affects the cell performance faster than the other chloride salts, therefore the presence of the cation in the contaminant solutions acted positively, slowing and/or reducing the decrease in the cell performance. 
There was no significant performance drop due to $\mathrm{NiCl}_{2}$ and $\mathrm{MgCl}_{2}$. Overall cell performance degradation was ranked as $\mathrm{HCl}, \mathrm{AlCl}_{3}>\mathrm{FeCl}_{3}>\mathrm{CrCl}_{3}>\mathrm{NiCl}_{2}, \mathrm{MgCl}_{2}$. Chloride was found to reach the CCM surface through the GDL and resulted in loss of ECSA. The decrease of $\mathrm{RH}$ from $120 \%$ to $70 \%$ further increased the effect of the contaminant, i.e. $\mathrm{AlCl}_{3}$. In this work, all the results were based on Gore MEA. For different MEAs with different catalyst and loading, and different ionomer formulations, the quantitative results may change; however, we do not anticipate a change in observed trends. 


\subsection{References}

1. X. Cheng, Z. Shi, N. Glass, L. Zhang, J. Zhang, D. Song, Z. Liu, H. Wang and J. Shen, J. Power Sources, 165, 739 (2007).

2. H. Li, K. Tsay, H. Wang, J. Shen, S. Wu, J. Zhang, N. Jia, S. Wessel, R. Abouatallah and N. Joos, J. Power Sources, 195, 8089 (2010).

3. S. T. Ali, Q. Li, C. Pan, J. O. Jensen, L. P. Nielsen and P. Møller, Int. J. Hydrogen Energy, 36, 1628 (2011).

4. T. J. Schmidt, U. A. Paulus, H. A. Gasteiger and R. J. Behm, J. Electroanal. Chem., 508, 41 (2001).

5. H. Li, H. Wang, W. Qian, S. Zhang, S. Wessel, T. T. H. Cheng, J. Shen and S. Wu, J. Power Sources, 196, 6249 (2011).

6. A. P. Yadav, A. Nishikata and T. Tsuru, Electrochim. Acta, 52, 7444 (2007).

7. A. Lam, H. Li, S. Zhang, H. Wang, D. P. Wilkinson, S. Wessel and T. T. H. Cheng, J. Power Sources, 205, 235 (2012).

8. O. A. Baturina, A. Epshteyn, P. A. Northrup and K. E. Swider-Lyons, J. Electrochem. Soc., 158, B1198 (2011).

9. O. A. Baturina, P. Northrup and K. Swider-Lyons, in Meeting Abstracts, Abstract \#1299, MA2012-02, The Electrochemical Society (2012).

10. H. Li, S. Zhang, W. Qian, Y. Yu, X. Z. Yuan, H. Wang, M. Jiang, S. Wessel and T. T. H. Cheng, J. Power Sources, 218, 375 (2012).

11. A. J. Steinbach, C. V. Hamilton and M. K. Debe, ECS Trans., 11(1), 889 (2007).

12. W. Yan, H. Chu, Y. Liu, F. Chen and J. Jang, Int. J. Hydrogen Energy, 36, 5435 (2011).

13. K. Matsuoka, S. Sakamoto, K. Nakato, A. Hamada and Y. Itoh, J. Power Sources, 179, 560 (2008).

14. T. Okada, in Handbook of Fuel Cells- Fundamentals, Technology and Applications., W. Vielstich, H. A. Gasteiger, A. Lamm and H. Yokokawa. Editors, John Wiley \& Sons, Ltd (2010).

15. A. Pozio, R. Silva, M. De Francesco and L. Giorgi, Electrochim. Acta, 48, 1543 (2003).

16. M. Sulek, J. Adams, S. Kaberline, M. Ricketts and J. R. Waldecker, J. Power Sources, 196, 8967 (2011).

17. J. Qi, X. Wang, U. Pasaogullari, L. Bonville and T. Molter, J. Electrochem. Soc., 160, F916 (2013).

18. J. Qi, X. Wang, O. Ozdemir, M. A. Uddin, L. J. Bonville, U. Pasaogullari and T. Molter, ECS Trans., 58(1), 537 (2013).

19. M. A. Uddin, X. Wang, J. Qi, M. O. Ozdemir, L. J. Bonville, U. Pasaogullari and T. Molter, ECS Trans., 58(1), 543 (2013).

20. X. Wang, J. Qi, O. Ozdemir, A. Uddin, U. Pasaogullari, L. Bonville, and T. Molter, J. Electrochem. Soc., 161, F1006 (2014).

21. M. A. Uddin, J. Qi, X. Wang, M. O. Ozdemir, N. K. H. Dalasm, L. Bonville, U. Pasaogullari and T. Molter, ECS Trans., 61(12), 37 (2014).

22. M. A. Uddin, X. Wang, M. O. Ozdemir, J. Qi, L. Bonville, U. Pasaogullari and T. Molter, ECS Trans., 61(12), 49 (2014). 
23. M. A. Uddin, J. Park, X. Wang, J. Qi, L. Bonville, U. Pasaogullari and T. Molter, ECS Trans., 64(3), 537 (2014).

24. M. F. Serincan, U. Pasaogullari, and T, Molter, Int. J. Hydrogen Energy, 35, 5539 (2010).

25. M. A. Uddin, and U. Pasaogullari, J. Electrochem. Soc., 61, F1081 (2014).

26. P. Patnaik, Handbook of Inorganic Chemicals, McGraw-Hill, New York (2002).

27. D. R. Lide, CRC Handbook of Chemistry and Physics 2006-2007: A Ready-Reference Book of Chemical and Physical Data, CRC press, Florida (2006).

28. T. Molter, The effects of cationic contamination on the physio-chemical properties of perfluoroionomer membranes, PhD Dissertation, ETD Collection for University of Connecticut, Paper AAI3314616 ( 2008). 
Table 2.1. List of chemicals and their solubility in water

Chemicals*

Solubility in water $(\mathbf{M})$

\begin{tabular}{cc}
\hline $\mathrm{HCl}$ & $19.74\left(20^{\circ} \mathrm{C}\right)^{26}$ \\
$\mathrm{Al}(\mathrm{Cl})_{3}$ & $1.87\left(25^{\circ} \mathrm{C}\right)^{27}$ \\
$\mathrm{Fe}(\mathrm{Cl})_{3}$ & $3.38\left(25^{\circ} \mathrm{C}\right)^{27}$ \\
$\mathrm{Cr}(\mathrm{Cl})_{3}$ & $2.19\left(20^{\circ} \mathrm{C}\right)^{26}$ \\
$\mathrm{Ni}(\mathrm{Cl})_{2}$ & $2.84\left(25^{\circ} \mathrm{C}\right)^{27}$ \\
$\mathrm{Mg}(\mathrm{Cl})_{2}$ & $2.75\left(25^{\circ} \mathrm{C}\right)^{27}$
\end{tabular}

*All chemicals are hexahydrate compound except $\mathrm{HCl}$ 


\begin{tabular}{|c|c|c|c|c|c|}
\hline $\begin{array}{l}\text { Cell } \\
\text { No. }\end{array}$ & Contaminants & $\begin{array}{l}\text { Concentration } \\
\qquad(\mathrm{mM})\end{array}$ & $\begin{array}{l}\text { Relative } \\
\text { humidity } \\
\text { (RH), A/C }\end{array}$ & $\begin{array}{l}\mathrm{Cl}^{-} \text {in } \\
\text { air } \\
(\mathrm{ppm})\end{array}$ & Operating conditions \\
\hline 1 & $\mathrm{HCl}$ & 28.5 & $25 / 120 \%$ & 50 & A/C: $10 / 4$ stoich \\
\hline 2 & $\mathrm{Al}(\mathrm{Cl})_{3}$ & 9.5 & $25 / 120 \%$ & 50 & $1.5 / 15$ psig back pressure \\
\hline 3 & $\mathrm{Fe}(\mathrm{Cl})_{3}$ & 9.5 & $25 / 120 \%$ & 50 & 1.75/1.66 slpm $\mathrm{H}_{2} /$ Air flow \\
\hline 4 & $\mathrm{Cr}(\mathrm{Cl})_{3}$ & 9.5 & $25 / 120 \%$ & 50 & rate \\
\hline 5 & $\operatorname{Mg}(\mathrm{Cl})_{2}$ & 14.25 & $25 / 120 \%$ & 50 & \\
\hline 6 & $\mathrm{Ni}(\mathrm{Cl})_{2}$ & 14.25 & $25 / 120 \%$ & 50 & \\
\hline 7 & $\mathrm{Al}(\mathrm{Cl})_{3}$ & 9.5 & $25 / 70 \%$ & 50 & \\
\hline
\end{tabular}




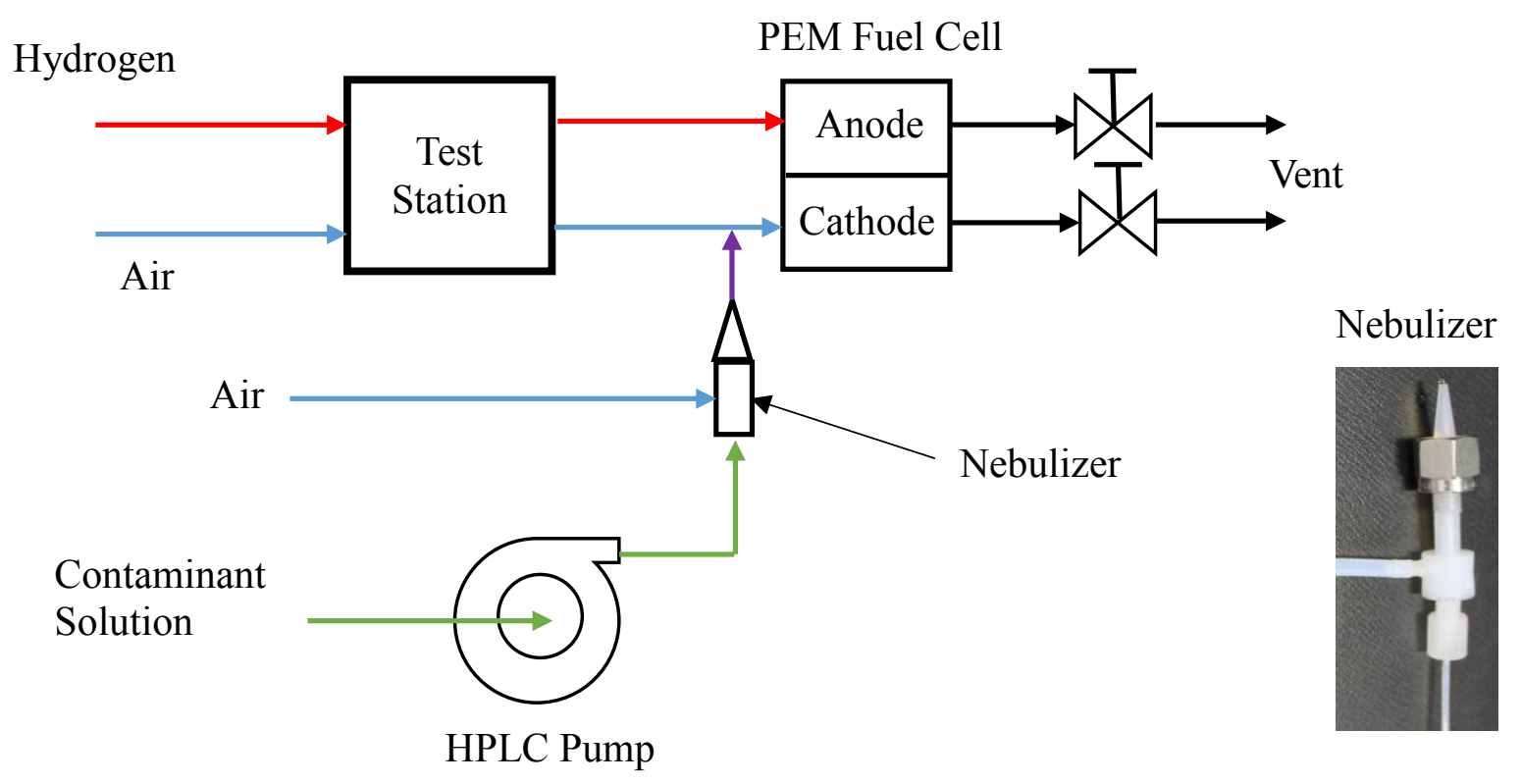

Fig. 2.1. Schematic diagram of the experimental setup. Micro flow Nebulizer with a HPLC pump was used to generate a fine spray of contaminant solution. 


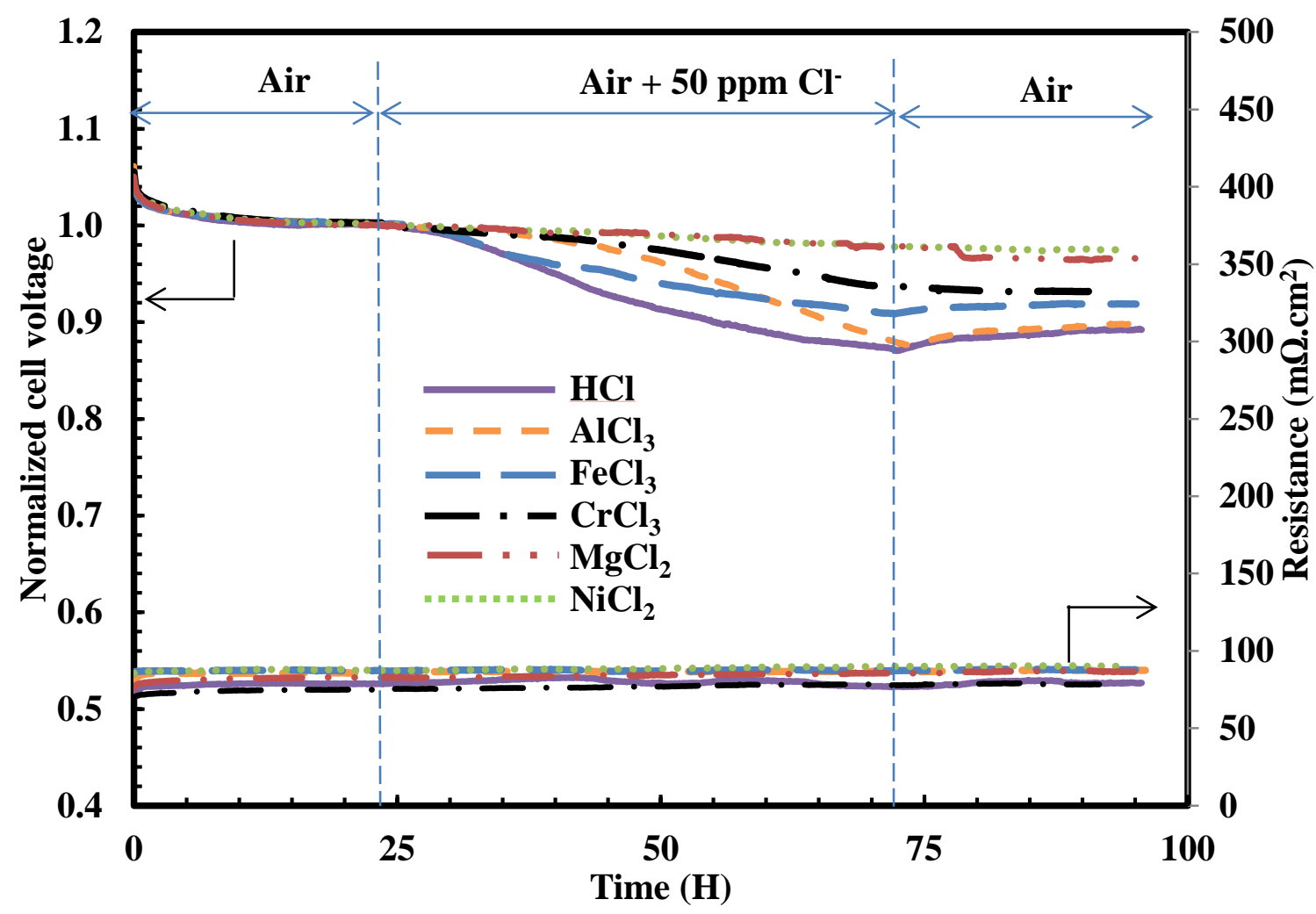

Fig. 2.2. Cell performances measured at $1 \mathrm{~A} / \mathrm{cm}^{2}$ when cells were exposed to $\mathrm{HCl}$ (cell 1), $\mathrm{AlCl}_{3}$ (cell 2), $\mathrm{FeCl}_{3}$ (cell 3), $\mathrm{CrCl}_{3}$ (cell 4), $\mathrm{MgCl}_{2}$ (cell 5), and $\mathrm{NiCl}_{2}$ (cell 6). Other operating conditions are listed in Table 3.1. 


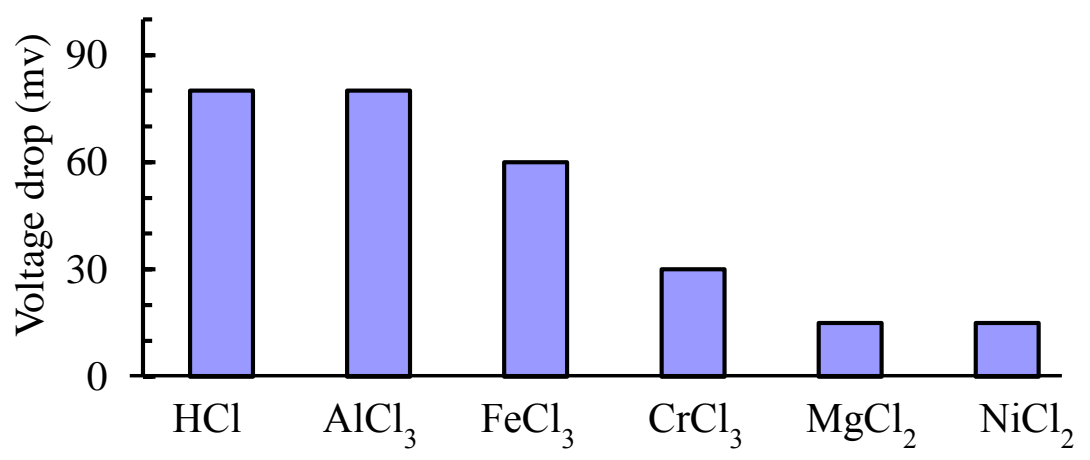

Fig. 2.3. Voltage drop during contamination. Voltage drops are the voltage difference between contaminant injection start (voltage corresponding to $24 \mathrm{~h}$ in fig. 2.2) and end of the injection (voltage corresponding to $72 \mathrm{~h}$ in fig. 2.2). 


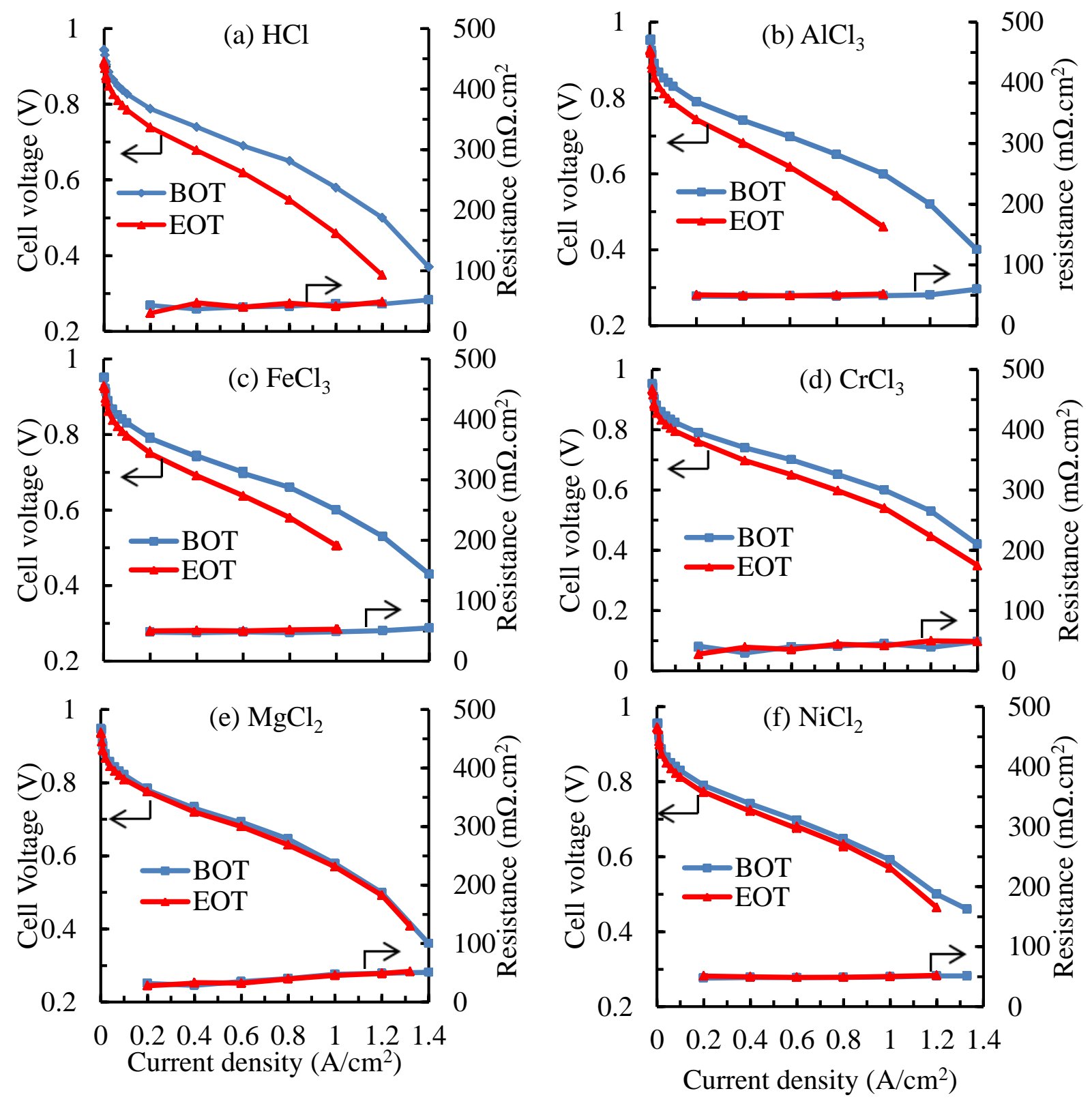

Fig. 2.4. Polarization curves measured at $\mathrm{BOT}$ and $\mathrm{EOT}$ with (a) $\mathrm{HCl}$ (cell 1), (b) $\mathrm{AlCl}_{3}$ (cell 2), (c) $\mathrm{FeCl}_{3}$ (cell 3), (d) $\mathrm{CrCl}_{3}$ (cell 4), (e) $\mathrm{MgCl}_{2}$ (cell 5), and (f) $\mathrm{NiCl}_{2}$ (cell 6). Operating conditions: cell temperature: $80{ }^{\circ} \mathrm{C}$; minimum flow rate $\mathrm{H}_{2} /$ air: $200 \mathrm{sccm}$; A/C: 2/2 stoich, 100/75\% RH, 0/0 psig back pressure. 

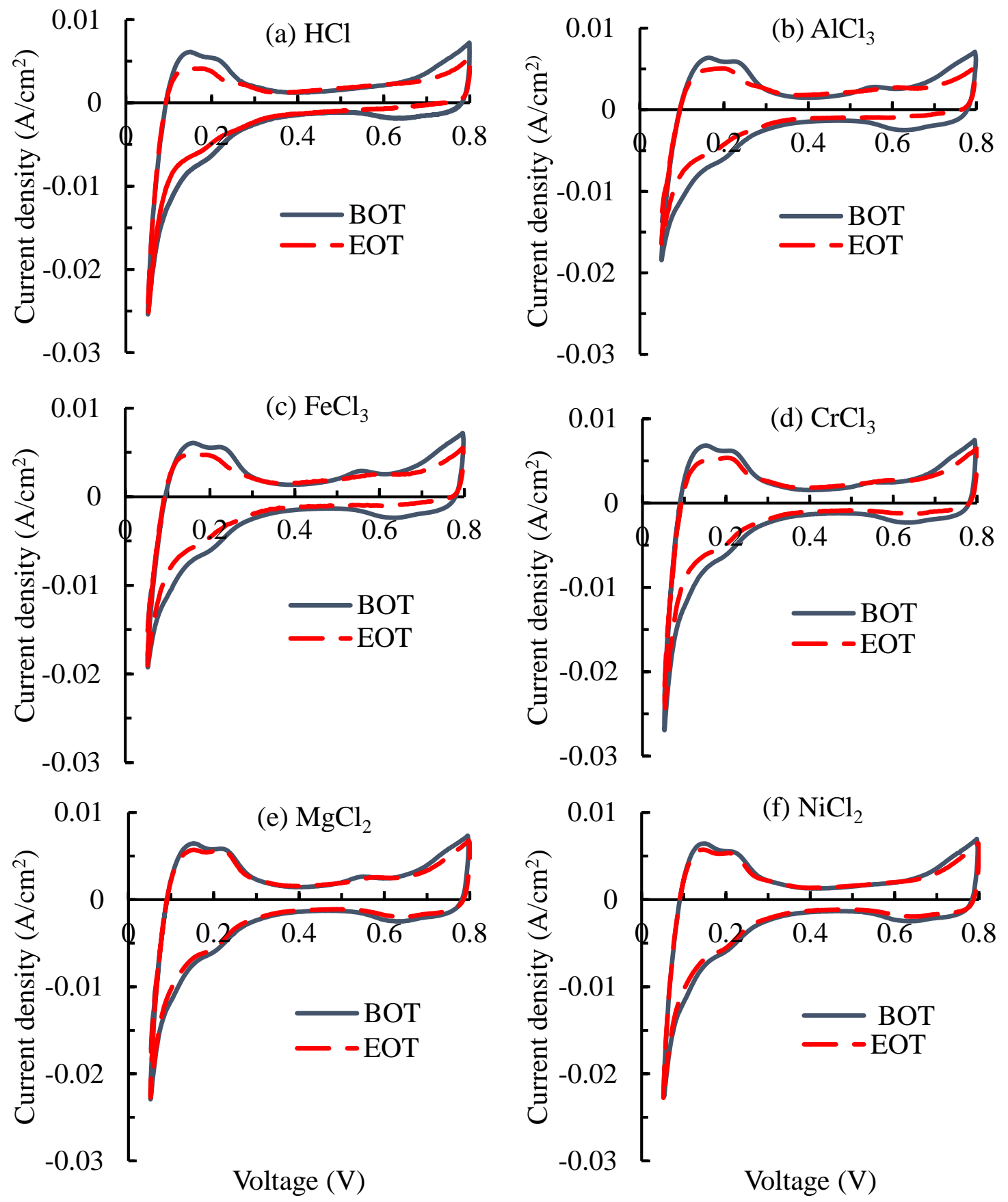

Fig. 2.5. Cathode CV curves measured at BOT and EOT for contamination test with (a) $\mathrm{HCl}$ (cell 1), (b) $\&$ Pt Ma :ell 2), (c) $\mathrm{FeCl}_{3}$ (cell 3), (d) $\mathrm{CrCl}_{3}$ (cell 4), (e) $\mathrm{MgCl}_{2}$ (cell 5), and (f) $\mathrm{NiCl}_{2}$ (cell 6). Operating conditions: cell temperature: $80{ }^{\circ} \mathrm{C}$; flow rate $\mathrm{H}_{2} / \mathrm{N} 2$ : $250 \mathrm{sccm}$; A/C: 100/75\% RH, 0/0 psig back pressure, scan rate $20 \mathrm{mV} / \mathrm{s}$. 

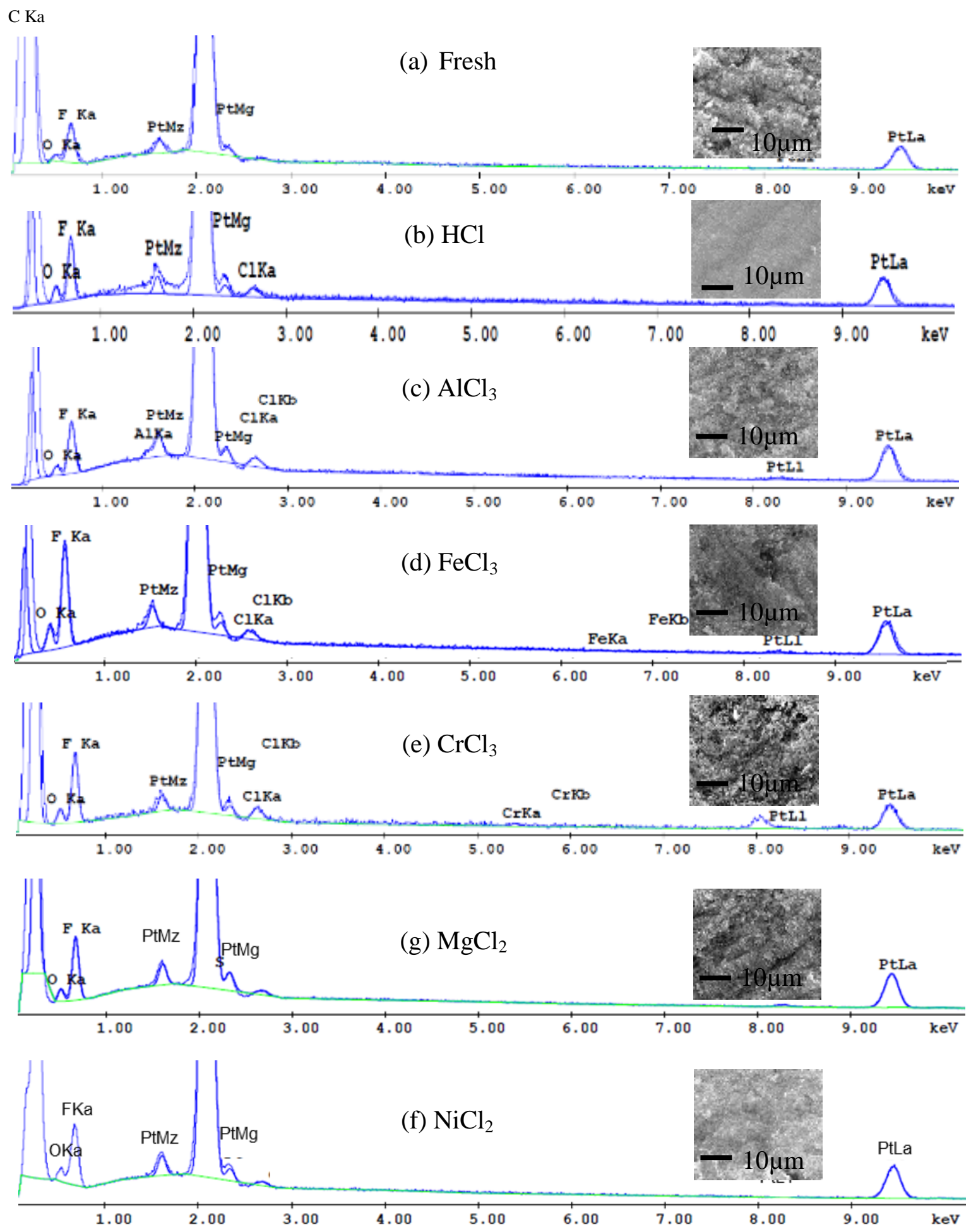

Fig. 2.6. SEM/EDX for cathode side of CCM surface of a fresh sample (a) and the cells tested with $\mathrm{HCl}$ (b), $\mathrm{AlCl}_{3}$ (c), $\mathrm{FeCl}_{3}$ (d), $\mathrm{CrCl}_{3}$ (e), $\mathrm{MgCl}_{2}$ (f), and $\mathrm{NiCl}_{2}$ (g). 


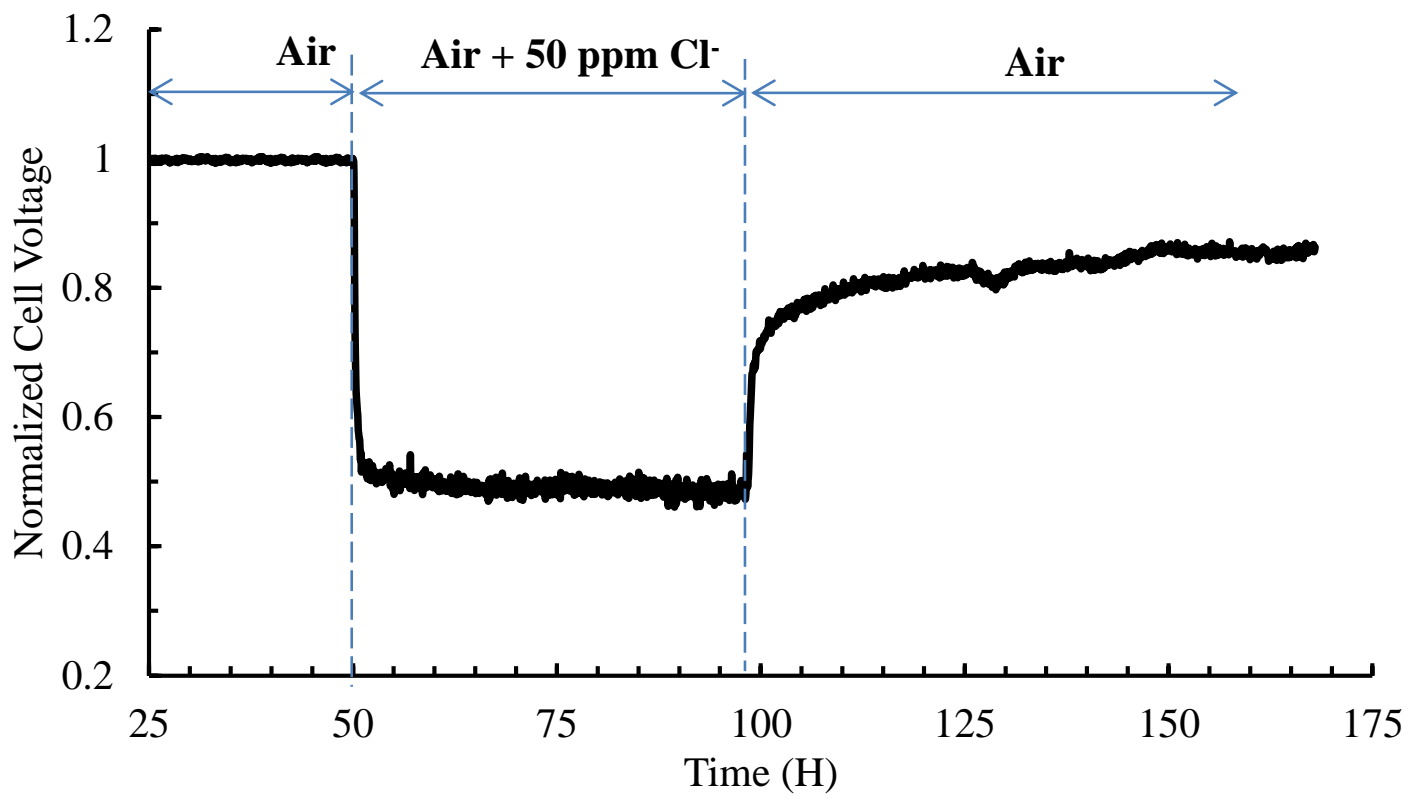

Fig. 2.7. Cell performance measured at $1 \mathrm{~A} / \mathrm{cm}^{2}$ when cell was exposed to $\mathrm{AlCl}_{3}$ (cell 7). Other operating conditions are listed in Table 3.1. 

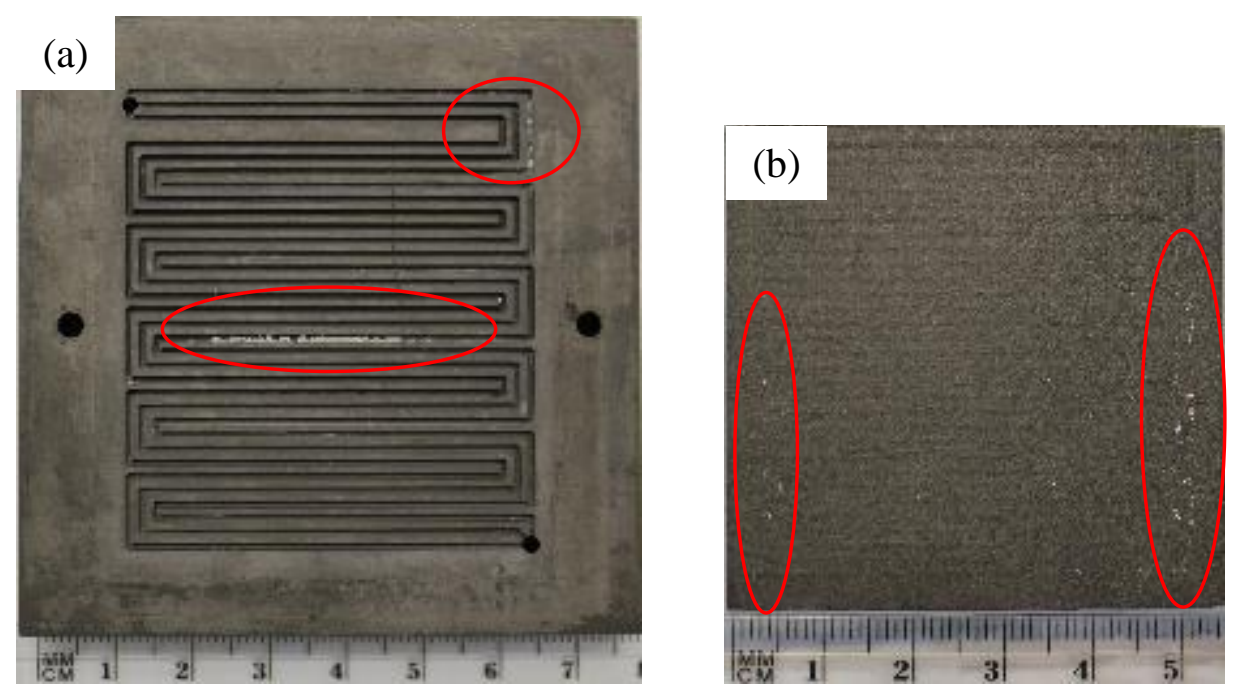

Fig. 2.8. Images of (a) cathode flow field and (b) cathode GDL surface (gas side) of cell 7 after contamination test with $\mathrm{AlCl}_{3}$. White deposits are shown with the red mark. 

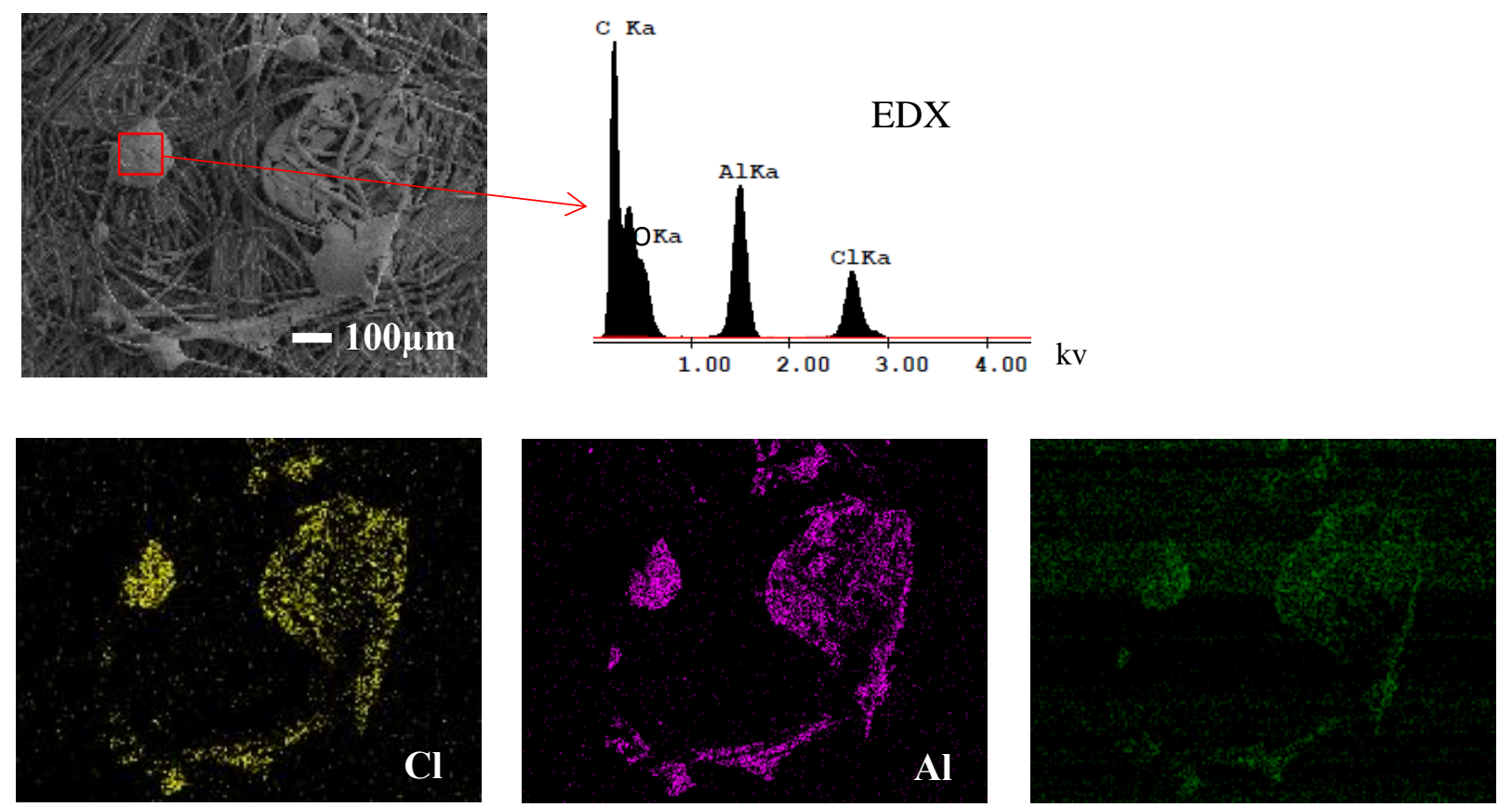

Fig. 2.9. SEM image of cathode GDL surface (gas side) of cell 7 after contamination test with $\mathrm{AlCl}_{3}$ with elemental spectrum of the whole SEM image and elemental map of $\mathrm{Al}$, $\mathrm{Cl}$, and $\mathrm{O}$. 

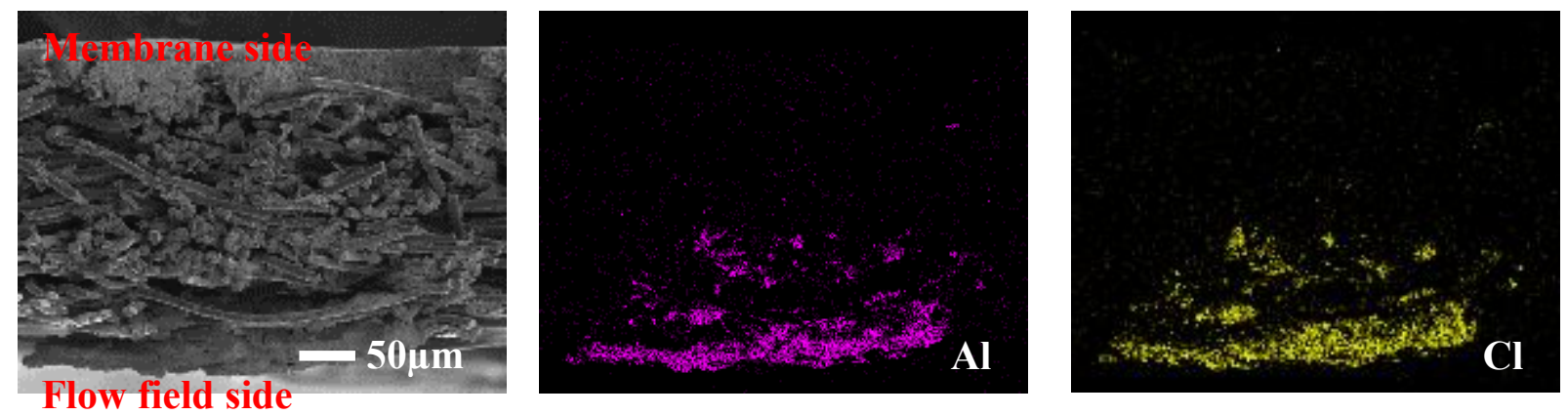

Fig. 2.10. SEM image of cathode GDL cross-section of cell 7 after contamination test with $\mathrm{AlCl}_{3}$ and elemental map of $\mathrm{Al}$ and $\mathrm{Cl}$ of that cross-section. 

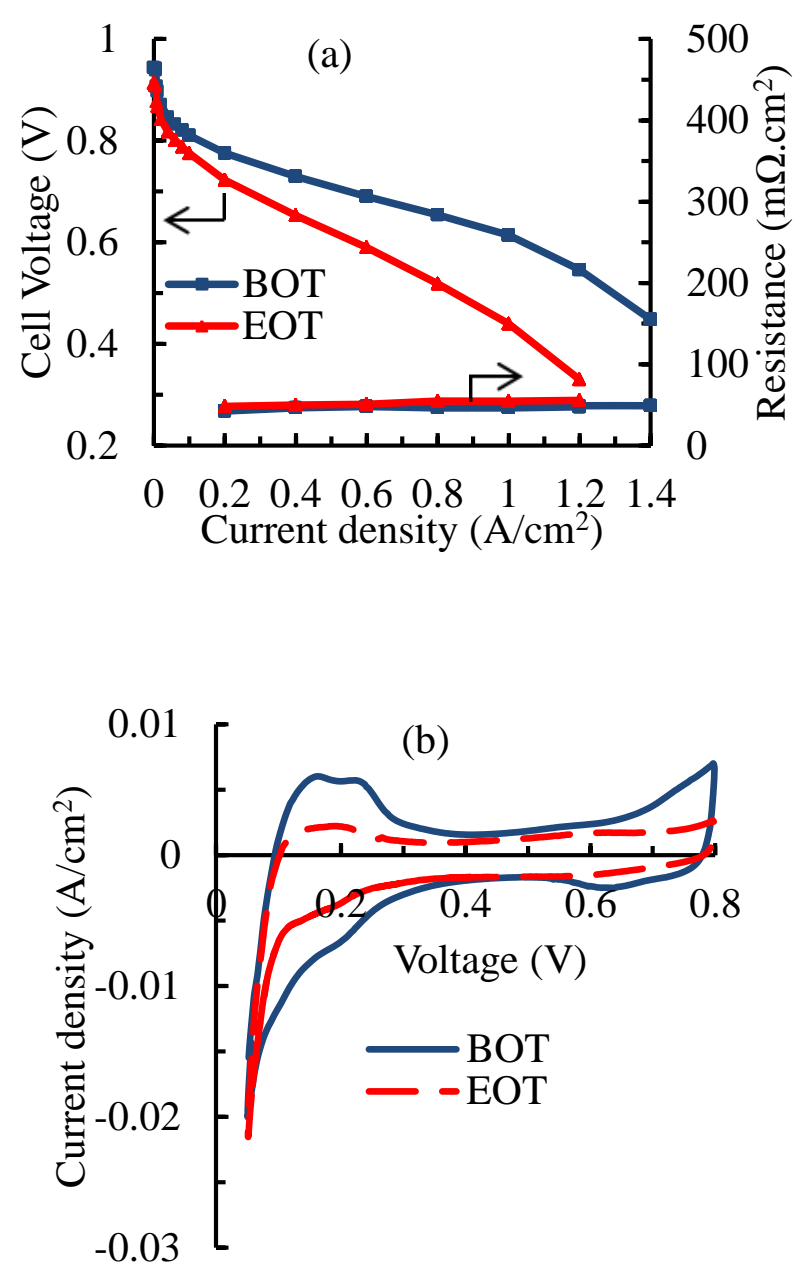

Fig. 2.11. (a) Polarization curves (b) Cathode CV curves at BOT and EOT for contamination test with $\mathrm{AlCl}_{3}$ (cell 7). 


\section{COMPUTATIONAL MODELING OF FOREIGN CATION CONTAMINATION IN PEFCS}

\subsection{Introduction}

Polymer electrolyte membrane (PEM) is a key component of the polymer electrolyte membrane fuel cell (PEFC). PEM is vulnerable to cationic impurities present in the air and fuel stream and/or originated from the cell components. Almost all foreign cations have higher affinity to sulfonic acid group than proton and the presence of foreign cation in the membrane or catalyst layers results in reduced ionic conductivity, increased electro-osmotic drag and reduced water content. ${ }^{1}$

To understand the effect of cation contamination, several PEFC models with varying degree of complexity were presented. Okada first developed a simple water transport model in a contaminated two-cation system membrane. They assumed a cation infected zone in the anode ${ }^{2}$ and the cathode ${ }^{3}$ where a prescribed profile for cation was considered. In their model, they did not include the transport of foreign cation in the membrane.

Kienitz et al. developed a one-dimensional model for a cathode electrode ${ }^{4}$ and for a fuel cell membrane ${ }^{5}$ utilizing dilute solution theory to model the foreign cation transport. They outlined three effects due to cationic contamination, which are: (i) a decrease in limiting current; (ii) an increase in activation overpotential; and (iii) a change in apparent working membrane conductivity that does not match the high frequency resistance (HFR) data. They did not provide an expression for reaction kinetics; instead, 
their models either assumed constant current density or an empirical kinetic loss term in the oxygen reduction rate equation to account the effects of cation contamination.

Sodaye $e t a l .{ }^{6}$ utilized the concentrated solution theory to model the competitive absorption and transport of two foreign cations $\left(\mathrm{Cs}^{+}\right.$and $\left.\mathrm{Na}^{+}\right)$only in the membrane. Based on similar transport phenomena model, a complete fuel cell model with catalyst layers (CLs) and gas diffusion layers (GDLs) was developed in our group by Serincan et $a{ }^{7}$ The model included a Maxwell-Stefan type multi-component transport model which better matched the competitive absorption experimental data presented by Sodaye et $a l^{6}$ But the model only studied contamination effect on proton and water transport, it did not include contamination effect in any other transport equations such as oxygen. St-Pierre ${ }^{8,9}$ developed a transient fuel cell ohmic loss model with a focus on the membrane ion exchange with foreign cations. He only considered contamination effect on cation transport, and ion migration was assumed negligible. There were other attempts to model cation contamination effect on PEM based electrochemical hydrogen pump. ${ }^{10,11}$ But none of the above models did not consider cation contamination effect in a coupled transport phenomena related to cation, water, and oxygen.

In this chapter, a steady-state, one dimensional cation contamination model of the membrane electrode assembly (MEA) of PEFC is presented. The model considers the coupled transport phenomena related to cation, water, and oxygen, and foreign cation $\left(\mathrm{Na}^{+}\right)$is assumed to be present only in the air stream. Multi-component transport is utilized in the membrane to solve cation transport based on Serincan et al.'s model ${ }^{7}$ and dilute solution theory is used in case of water, hydrogen, and oxygen transport in the open pores of the catalyst layers. A spherical agglomerate model is utilized in the cathode 
catalyst layer (CCL), which is the first time foreign cations included in an agglomerate model. To understand the exact effects of the contamination on transport phenomena, first no contamination case is solved. Then step by step contamination effect is added to cation transport, water transport, and oxygen transport. Finally, effect on equilibrium potential due to proton concentration change is incorporated.

\subsection{Mathematical Model}

\subsubsection{Model description}

A schematic diagram of the model is shown in Fig. 3.1. Model consists of the anode catalyst layer, the polymer electrolyte membrane, PEM (e.g Nafion), and the cathode catalyst layer. Hydrogen enters through the anode and oxidizes to produce protons and electrons in the anode catalyst layer (ACL). Electrons travel through the external circuit and protons are transported through the PEM. Contaminated air enters through the cathode and reacts with protons and electrons to form water in the cathode catalyst layer (CCL).

The following assumptions are made in the model

- one dimensional model;

- steady state and isothermal conditions;

- ideal gas mixtures;

- electroneutrality is valid in the membrane;

In this model, a mixed domain approach is used. ${ }^{12}$ Ionomer phase water concentration is solved in the anode catalyst layer (ACL), the PEM, and the cathode catalyst layer (CCL). Gas phase water concentration is solved only in the ACL and CCL, 
and there is water exchange between the ionomer phase and the gas phase in the catalyst layers. Oxygen concentration is solved only in the CCL, and hydrogen concentration is solved only in the ACL.

\subsubsection{Proton/Foreign Cation Transport}

In this model, three charged species are considered in the PEM: positively charged proton and one foreign cation $\left(\mathrm{Na}^{+}\right)$and negatively charged sulfonic acid sidechains. Sulfonic acid side-chains are considered as stationary species. According to Gibbs-Duhem restriction two species equations are independent. ${ }^{13}$ Therefore, we solve Eq. 1 in Table 3.1 for $\mathrm{H}^{+}$and $\mathrm{Na}^{+}$.

In Eq. 1, $\mathrm{N}$ represents the total flux of cation. Serincan et al. ${ }^{7}$ derived cation flux equation using generalized Maxwell-Stefan (MS) approach. It can be expressed as

$\{\mathrm{N}\}=-2 \mathrm{c}_{\mathrm{so}_{3}^{-}}[\mathrm{B}]^{-1}\{\nabla \mathrm{y}\}-\frac{2 \mathrm{Fc}_{\mathrm{So}_{3}^{-}}}{\mathrm{RT}}[\mathrm{B}]^{-1}\{\mathrm{z} \cdot \mathrm{y}\} \nabla \phi$

where $\mathrm{y}$ is the relative occupancy and $[\mathrm{B}]$ is a matrix including binary diffusivities and relative occupancies. The elements of $[\mathrm{B}] \operatorname{are}^{14}$

$\mathrm{B}_{\mathrm{jj}}=\sum_{\substack{\mathrm{k}=1 \\ \mathrm{k} \neq \mathrm{j}}}^{\mathrm{n}} \frac{\mathrm{y}_{\mathrm{k}}}{\mathrm{D}_{\mathrm{jk}}}$

$\mathrm{B}_{\mathrm{jk}}=-\frac{\mathrm{y}_{\mathrm{j}}}{\mathrm{D}_{\mathrm{jk}}}$

Binary diffusion coefficient, $\mathrm{D}_{\mathrm{jk}}$ is calculated by ${ }^{13}$

$D_{j k}=\left(D_{j, M}\right)^{x_{j}} \times\left(D_{k, M}\right)^{x_{k}}$

where $D_{j, M}$ and $D_{k, M}$ are self-diffusivities of species $j$ and $k$. Self-diffusivity of proton is calculated from Nernst-Einstein relation as 
$\kappa_{\mathrm{H}^{+}}=\mathrm{c}_{\mathrm{H}^{+}} \mathrm{D}_{\mathrm{j}, \mathrm{H}^{+}} \frac{\mathrm{z}_{\mathrm{H}^{+}}^{2} \mathrm{~F}^{2}}{\mathrm{RT}}$

where $\kappa_{\mathrm{H}^{+}}$is the conductivity of proton. An expression for conductivity of membrane in pure proton form is used from Springer et al. ${ }^{15}$

$\kappa_{\mathrm{H}^{+}}=(0.5139 \lambda-0.326) \exp \left[1268\left(\frac{1}{303}-\frac{1}{\mathrm{~T}}\right)\right]$

Self-diffusivity of $\mathrm{Na}^{+}$is calculated using a relation in terms of polymer volume fraction and water content in the membrane $e^{16,17}$

$\mathrm{D}_{\mathrm{j}, \mathrm{Na}} \mathrm{a}^{+}=\mathrm{D}_{\mathrm{Na}^{+}}^{\mathrm{aq}} \exp \left(-\mathrm{b} \frac{\mathrm{V}_{\mathrm{p}}}{1-\mathrm{V}_{\mathrm{p}}}\right)$

where $\mathrm{D}_{\mathrm{Na}^{+}}^{\mathrm{aq}}$ is the aqueous diffusion coefficient of $\mathrm{Na}^{+}, \mathrm{V}_{\mathrm{p}}$ is the volume fraction of polymer in the water-swollen membrane, and $\mathrm{b}$ is an empirical parameter. For $\mathrm{a}$ monovalent cation, b is $0.21 \cdot{ }^{17} \mathrm{Eq}$. (12) accounts for the tortuosity effect due to polymer volume fraction in polymer matrix. All the physical and chemical properties are listed in Table 3.2.

\subsubsection{Water transport}

Water transport across the catalyst layers occur both in the ionomer phase and in the gas phase, and only ionomer phase water exists in the membrane. Mass conservation equations for both phases of water are the Eq. 2 and 3 in Table 3.1. In those equations, $\mathrm{h}_{\mathrm{m}}$ represents the mass transfer coefficient of water between gas phase and ionomer phase, and $\lambda^{\mathrm{eq}}$ is equivalent water content at the corresponding gas phase molar concentration, $\mathrm{C}_{\mathrm{w}}^{\mathrm{g}}$ 
As foreign cations have higher affinity to the sulfonic acid group than proton and replace proton from active sites, the equivalent water content is calculated by the following equation to account the presence of both $\mathrm{H}^{+}$and $\mathrm{Na}^{+}$

$\lambda^{\mathrm{eq}}=\mathrm{y}_{\mathrm{H}^{+}} \times \lambda_{\mathrm{H}^{+}}^{\mathrm{eq}}+\mathrm{y}_{\mathrm{Na}^{+}} \times \lambda_{\mathrm{Na}^{+}}^{\mathrm{eq}}$

where $\lambda_{\mathrm{H}^{+}}^{\text {eq }}$ and $\lambda_{\mathrm{Na}^{+}}^{\text {eq }}$ are water uptake for membrane in $\mathrm{H}^{+}$form and $\mathrm{Na}^{+}$form, respectively.

Springer et al. ${ }^{15}$ provided an expression of water content in proton form membrane.

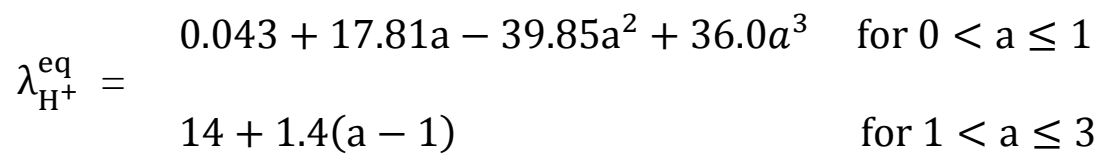

And Serincan et al. ${ }^{7}$ used an expression for $\lambda_{\mathrm{Na}^{+}}^{\text {eq }}$ which was a curve fit to the experimental plot of Jalani and Datta. ${ }^{18}$

$\lambda_{\mathrm{Na}^{+}}^{\mathrm{eq}}=10.3 \mathrm{a}^{3}-4.73 \mathrm{a}^{2}+1.78 a+0.0149$

where the water activity, a is defined as

$\mathrm{a}=\frac{\mathrm{C}_{\mathrm{w}}^{\mathrm{g}} \mathrm{RT}}{\mathrm{P}^{\mathrm{sat}}}$

Related experiments in Eq. 14 and 15 were done at $30^{\circ} \mathrm{C}$. These expressions are used here, since no data are available at $80^{\circ} \mathrm{C}$ for foreign cations.

The effective water diffusivity, $\mathrm{D}_{\mathrm{w}}^{\mathrm{m}, \mathrm{eff}}$ in the membrane is calculated using a similar expression as Eq. (13) to account the presence of both $\mathrm{H}^{+}$and $\mathrm{Na}^{+}$in the membrane. For water diffusivity in $\mathrm{H}^{+}$form membrane, the following expression is used from Motupally et al. ${ }^{19}$ 


$$
\mathrm{D}_{\mathrm{w}, \mathrm{H}^{+}}^{\mathrm{m}}=\begin{array}{ll}
3.1 \times 10^{-7} \lambda\left(\mathrm{e}^{0.28 \lambda}-1\right) \cdot \mathrm{e}^{\left(-\frac{2346}{\mathrm{~T}}\right)} & \text { for } 0<\lambda \leq 3 \\
4.17 \times 10^{-8} \lambda\left(1+161 \mathrm{e}^{-\lambda}\right) \cdot \mathrm{e}^{-\frac{2346}{\mathrm{~T}}} & \text { otherwise }
\end{array}
$$

and for $\mathrm{Na}^{+}$form membrane, similar expression of Eq. (12) is used in terms of polymer volume fraction ${ }^{16}$

$\mathrm{D}_{\mathrm{w}, \mathrm{Na}}^{\mathrm{m}}{ }^{+}=\mathrm{D}_{\mathrm{w}}^{\mathrm{aq}} \exp \left(-\mathrm{b} \frac{\mathrm{V}_{\mathrm{p}}}{1-\mathrm{V}_{\mathrm{p}}}\right)$

In the above equation, water diffusivity in $\mathrm{Na}^{+}$form membrane not only depends on tortuosity factor due to polymer volume fraction but also tortuosity factor due to $\mathrm{Na}^{+}$ion. As membrane in $\mathrm{Na}^{+}$form has higher tortuosity compared to $\mathrm{H}^{+}$form membrane, water diffusivity decreases in $\mathrm{Na}^{+}$form. ${ }^{20}$ Moreover, from $\mathrm{H}^{+}$form to $\mathrm{Na}^{+}$form, equilibrium water uptake decreases, e.g. membrane water content decreases from $14\left(\mathrm{H}^{+}\right.$form) to $7.36\left(\mathrm{Na}^{+}\right.$form $)$at a unity water activity at $30{ }^{\circ} \mathrm{C} .{ }^{7}$

\subsubsection{Oxygen transport}

In CCL, a spherical agglomerate model is considered to account for micro-scale effects of foreign cations, e.g. effective oxygen diffusivity in the ionomer phase. It is assumed that outer layer of agglomerate is covered with a thin ionomer film and each agglomerate consists of cluster of carbon particle with Pt catalyst on its surface. Interior pores (primary) in each agglomerate are filled with ionomer. Secondary pores exist between the agglomerates to provide space for gas diffusion and these pores are partially or fully filled with water. Oxygen diffuses through the secondary pores and reaches to the agglomerate ionomer film surface. It is dissolved into the film surface and diffuses through the film to reach to the catalyst sites. 
Dissolved oxygen concentration is calculated in two steps: first, gas phase oxygen concentration is solved by the CFD model taking into account reaction kinetics and diffusion through secondary pores (Eq. 5 in Table 3.1) and then ionomer phase oxygen concentration is calculated using analytical relations.

The dissolved oxygen concentration at the pore-ionomer film interface is described by Henry's law:

$\mathrm{C}_{\mathrm{O}_{2}, \text { film-pore }}^{\mathrm{m}}=\frac{\mathrm{C}_{\mathrm{O}_{2}}^{\mathrm{g}}}{\mathrm{K}_{\mathrm{O}_{2}} /(R T)}$

The dissolved oxygen concentration at the interface of ionomer film and agglomerate core can be expressed as ${ }^{21}$

$\mathrm{C}_{\mathrm{O}_{2}}^{\mathrm{m}}=\left(1+\frac{\mathrm{AEk} \delta_{\mathrm{agg}}}{\mathrm{a}_{\mathrm{agg}} \mathrm{D}_{\mathrm{O}_{2}}^{\mathrm{m}}} \frac{\mathrm{r}_{\mathrm{agg}}+\delta_{\mathrm{agg}}}{\mathrm{r}_{\mathrm{agg}}}\right)^{-1} \mathrm{C}_{\mathrm{O}_{2}, \mathrm{film}-\text { pore }}^{\mathrm{m}}$

where $\mathrm{k}$ is the reaction rate constant. It is defined as

$\mathrm{k}=\frac{\mathrm{j}_{\mathrm{c}}}{4 \mathrm{FC}_{\mathrm{O}_{2}}^{\mathrm{m}}}$

All other terms in Eq. (20) and other related relations are taken from the study of KhajehHosseini-Dalasm et al. ${ }^{21-23}$ and corresponding parameters are provided in Table 3.3.

Oxygen diffusion coefficient - It is assumed that open pores in CCL contains water. To reach to the surface of the agglomerate ionomer film, oxygen passes through both liquid water and open space in the pores. Accounting for oxygen transport in both medium, a parallel model is assumed to calculate oxygen diffusion coefficient ${ }^{21}$

$\mathrm{D}_{\mathrm{O}_{2}}^{\mathrm{eff}}=\mathrm{D}_{\mathrm{O}_{2}, \mathrm{~g}}^{\mathrm{eff}} \frac{(1-s) \varepsilon_{\mathrm{cl}}}{\varepsilon_{\mathrm{cl}}+\varepsilon_{\mathrm{gcl}}\left(1-\varepsilon_{\mathrm{GDL}}\right)}+\mathrm{D}_{\mathrm{O}_{2}, \mathrm{w}}^{\mathrm{eff}} \frac{\mathrm{s} \varepsilon_{\mathrm{cl}}}{\varepsilon_{\mathrm{cl}}+\varepsilon_{\mathrm{gcl}}\left(1-\varepsilon_{\mathrm{GDL}}\right)}$ 
where $\mathrm{D}_{\mathrm{O}_{2}-\mathrm{g}}^{\text {eff }}$ and $\mathrm{D}_{\mathrm{O}_{2}-\mathrm{w}}^{\text {eff }}$ are the effective oxygen gas diffusion coefficients in gas pores and liquid water, respectively and Bruggemann correlation is used to calculate the effective diffusivity of oxygen.

$\mathrm{D}_{\mathrm{O}_{2}, \mathrm{~g}}^{\mathrm{eff}}=\left((1-\mathrm{s}) \varepsilon_{\mathrm{cl}}\right)^{1.5} \mathrm{D}_{\mathrm{O}_{2}, \mathrm{~g}}$

$\mathrm{D}_{\mathrm{O}_{2}, \mathrm{w}}^{\mathrm{eff}}=\left(\mathrm{s} \varepsilon_{\mathrm{cl}}\right)^{1.5} \mathrm{D}_{\mathrm{O}_{2}, \mathrm{w}}$

where $\mathrm{D}_{\mathrm{O}_{2}, \mathrm{~g}}$ and $\mathrm{D}_{\mathrm{O}_{2}, \mathrm{w}}$ are the diffusion coefficient of oxygen in gas phase and water phase, respectively and water phase diffusivity can be expressed as ${ }^{24}$

$\mathrm{D}_{\mathrm{O}_{2}, \mathrm{w}}=4522 \times 10^{-9} \exp \left(-\frac{2287.9}{\mathrm{~T}}\right)$

Dissolved oxygen diffusivity in ionomer phase, $\mathrm{D}_{\mathrm{O}_{2}}^{\mathrm{m}}$ is calculated using a similar approach as Eq. (13) to consider the effect of both $\mathrm{H}^{+}$and $\mathrm{Na}^{+}$presence in ionomer. Oxygen diffusivity in the ionomer in $\mathrm{H}^{+}$form is obtained from Sakai et al.'s experimental data for Nafion $125^{25}$ and diffusivity data for $\mathrm{Na}^{+}$form ionomer is reported by Ogumi et al. for Nafion $120^{26}$. Dissolved oxygen diffusivity value for cation uptaken membrane is smaller than those in the acid-form one. ${ }^{25}$

\subsubsection{Electrochemical kinetics}

The electrochemical reaction rate in the catalyst layers can be described using linear kinetics (due to sufficiently high reaction rates) and Tafel kinetics (due to sluggish reaction rate) simplifications of the Butler-Volmer equations in the anode and the cathode, respectively.

$\mathrm{j}_{\mathrm{a}}=\mathrm{aj}_{0, \mathrm{a}}^{\mathrm{ref}}\left(\mathrm{y}_{\mathrm{H}^{+}}\right)\left(\frac{\mathrm{C}_{\mathrm{H}_{2}}}{\mathrm{C}_{\mathrm{H}_{2}, \mathrm{ref}}}\right)^{\frac{1}{2}}\left(\frac{\alpha_{\mathrm{a}}+\alpha_{\mathrm{c}}}{\mathrm{RT}} \cdot \mathrm{F} \cdot \eta_{\mathrm{a}}\right) \quad$ at the anode 
$\mathrm{j}_{\mathrm{c}}=\mathrm{aj} \mathrm{j}_{0, \mathrm{c}}^{\mathrm{ref}}\left(\mathrm{y}_{\mathrm{H}^{+}}\right)\left(\frac{\mathrm{C}_{\mathrm{O}_{2}}^{\mathrm{m}}}{\mathrm{C}_{\mathrm{O}_{2}, \mathrm{ref}}^{\mathrm{m}}}\right) \exp \left(-\frac{\alpha_{\mathrm{c}}}{\mathrm{RT}} \cdot \mathrm{F} \cdot \eta_{\mathrm{c}}\right) \quad$ at the cathode

where $a j_{0, a}^{r e f}$ and $a j_{0, c}^{r e f}$ are the exchange current density in ACL and CCL, respectively and $\eta$ is surface overpotential. It is defined as

$\eta=\phi_{\mathrm{s}}-\phi_{\mathrm{e}}-\mathrm{V}_{\mathrm{eq}}$

where $\phi_{\mathrm{s}}$ and $\phi_{\mathrm{e}}$ are the solid phase potential and electrolyte phase potential, respectively. It is assumed that due to relatively very large electric conductivities, negligible ohmic potential drop occurs in the gas diffusion layers, catalyst layers, and current collectors. Therefore, solid phase potentials are taken as ${ }^{27}$

$\phi_{\mathrm{s}}=\begin{array}{ll}0 & \text { at the anode } \\ \mathrm{V}_{\text {cell }} & \text { at the cathode }\end{array}$

The equilibrium potential of an electrode is determined by the Nernst equation. Taking the activity of hydrogen, oxygen, and water as 1 and the activity of proton as the relative occupancy of proton in ionomer, equilibrium potential can be expressed as

$$
\begin{aligned}
& \mathrm{V}_{\mathrm{eq}} \quad \mathrm{V}_{\mathrm{a}}+\frac{\mathrm{RT}}{\mathrm{nF}} \ln \left(\mathrm{y}_{\mathrm{H}^{+}}^{2}\right) \quad \text { at the anode } \\
& =\quad \mathrm{V}_{\mathrm{c}}+\frac{\mathrm{RT}}{\mathrm{nF}} \ln \left(\mathrm{y}_{\mathrm{H}^{+}}^{2}\right) \quad \text { at the cathode }
\end{aligned}
$$

where $V_{a}$ and $V_{c}$ are reversible potential in anode and cathode side, respectively. $V_{a}$ is taken as zero, and $\mathrm{V}_{\mathrm{c}}$ is expressed as ${ }^{27}$

$\mathrm{V}_{\mathrm{c}}=1.23-9 \times 10^{-4}(\mathrm{~T}-298.15)$

Due to $\mathrm{Na}^{+}$contamination, concentration of $\mathrm{H}^{+}$decreases and causes a decrease in the cathode equilibrium potential. 


\subsubsection{Boundary conditions}

There are six governing equations presented so far for seven unknowns:

$\phi, \mathrm{y}_{\mathrm{H}^{+}}, \mathrm{y}_{\mathrm{Na}^{+}}, \lambda, \mathrm{C}_{\mathrm{W}}^{\mathrm{g}}, \mathrm{C}_{\mathrm{O}_{2}}^{\mathrm{g}}$, and $\mathrm{C}_{\mathrm{H}_{2}}^{\mathrm{g}}$. The final relation comes from the electroneutrality. It is assumed that either $\mathrm{H}^{+}$or $\mathrm{Na}^{+}$occupies the active sites in the ionomer, therefore, $\mathrm{y}_{\mathrm{H}^{+}}+\mathrm{y}_{\mathrm{Na}^{+}}=1$. It is also assumed that the GDL side of the CCL is fully occupied by $\mathrm{Na}^{+}$and in the GDL side of ACL, $\mathrm{Na}^{+}$occupancy is zero. All other boundary conditions are shown in Fig. 3.2.

\subsection{Numerical Method}

All the differential equations were discretized using finite volume method. ${ }^{28}$ The first order upwind scheme is used to calculate the convective-diffusive flux through each computational cell. Discretized equations are solved using MATLAB.

\subsection{Results and Discussion}

Fig. 3.3 shows the protonic current density distribution along MEA thickness during cell operation at $0.7 \mathrm{~V}$. Current density profiles are plotted for both noncontaminated and contaminated cases. First, no contamination case is solved and then contamination effects are added sequentially into the proton transport, water transport, oxygen transport, and finally the equilibrium potential. In no contamination case, it is assumed that all sulfonic acid sites are occupied by proton. Protonic current density across the PEM is calculated as $0.72 \mathrm{~A} / \mathrm{cm}^{2}$ and proton is transported only by migration due to electrostatic potential. 
Contamination effect is first studied by solving cation transport equation (Eq. 1 in Table 3.1). As $\mathrm{Na}^{+}$has higher affinity to sulfonic acid site, it replaces proton and occupies the site and decreases proton concentration in ionomer. It also decreases the proton production and consumption rate in the catalyst layers because proton production and consumption rate (Eq. (26) and (27)) are dependent to proton concentration. As a result the protonic current density decreases from $0.72 \mathrm{~A} / \mathrm{cm}^{2}$ to $0.43 \mathrm{~A} / \mathrm{cm}^{2}$, a $40.3 \%$ decrease in current density. As $\mathrm{Na}^{+}$replaces proton from sulfonic acid sites, a gradient of proton concentration is created across the MEA from anode to cathode. Consequently in addition to migration, proton is also transported by diffusion due to concentration gradient.

Next, the effect of cation is added to the water transport. Presence of cation in the ionomer decreases the water diffusivity affecting the water content in the ionomer phase. As the membrane proton conductivity is a strong function of water content, protonic current density further decreases from $0.43 \mathrm{~A} / \mathrm{cm}^{2}$ to $0.38 \mathrm{~A} / \mathrm{cm}^{2}$. Then the effect of cation is considered in the oxygen transport. Oxygen diffusivity in the ionomer also decreases due to foreign cation and current density further decreases to $0.34 \mathrm{~A} / \mathrm{cm}^{2}$. Finally, contamination effect is considered in the calculation of equilibrium potential by the Nernst equation, which is sensitive to proton concentration. As proton concentration decreases due to $\mathrm{Na}^{+}$occupancy, equilibrium potential drops and current density further decreases to $0.25 \mathrm{~A} / \mathrm{cm}^{2}$. So, total $65.3 \%$ decrease in current density occurs due to the effect of cation contamination on all factors.

When the membrane thickness is reduced from $30 \mu \mathrm{m}$ (Fig. 3.3) to $20 \mu \mathrm{m}$ (Fig. 3.4), the current density increases in both no contamination and contamination cases due to decrease in membrane resistance. In this case, $62 \%$ decrease in current density (from 
$0.79 \mathrm{~A} / \mathrm{cm}^{2}$ to $0.3 \mathrm{~A} / \mathrm{cm}^{2}$ ) occurs due to the effect of cation contamination. In case of dry condition (50\% RH in anode and cathode (Fig. 3.5)), the current density is much lower than the wet condition ( $80 \%$ and $100 \%$ RH in anode and cathode, respectively (Fig. 3.3)) mainly due to decrease in water content. In no contamination case, the current density decreases from $0.72 \mathrm{~A} / \mathrm{cm}^{2}$ (Fig. 3.3) to $0.41 \mathrm{~A} / \mathrm{cm}^{2}$ (Fig. 3.5), and in contamination case, the current density is almost negligible.

Mikkola et al. experimentally tested the effect of $\mathrm{NaCl}$ injecting into the air stream of an operating fuel cell at $0.6 \mathrm{~V} .{ }^{29}$ Within $100 \mathrm{~h}$ injection, they observed $30 \%$ decrease in current density (form $0.9 \mathrm{~A} / \mathrm{cm}^{2}$ to $0.63 \mathrm{~A} / \mathrm{cm}^{2}$ ), which is comparable to our predictions. They attributed the performance loss mainly due to $\mathrm{Na}^{+}$ion. Although enough $\mathrm{Na}^{+}$ions were delivered to the cell every 15 seconds to replace every proton in the membrane, performance loss was lowered compared to the model due to the mass transfer barrier that the GDL represent, or the effect of cell potential pushing cations towards the cathode and thereby slowing the transport of $\mathrm{Na}+$ into the electrodes and membrane. ${ }^{29}$

Another way to represent the effect of cation contamination on different parameters is electrolyte phase potential profiles. Fig. 3.6 shows the phase potential profiles for no contamination and various contamination cases. For no contamination case, phase potential is much higher than all other contamination cases, and it decreases with the addition of contamination effect in different factors. It is due to the variation in cell current densities. Cell current density is higher for no contamination case. With the contamination, current density decreases which are shifted to the kinetic region in the performance curve and phase potentials decreases. For all the cases, phase potential 
remains nearly zero within the ACL which indicates very fast hydrogen oxidation reaction on the anode. ${ }^{30}$

Fig. 3.7 shows the predicted profiles for relative $\mathrm{Na}^{+}$occupancy in the ionomer along the MEA thickness. In no contamination case, there is no $\mathrm{Na}^{+}$occupancy and during contamination case, $\mathrm{Na}^{+}$is introduced from the cathode catalyst layer (CCL) side. As Nafion has higher affinity to $\mathrm{Na}^{+}$than $\mathrm{H}^{+1}, \mathrm{Na}^{+}$replaces proton and occupies the sulfonic acid site. This occupancy is expressed by the term "relative $\mathrm{Na}^{+}$occupancy" which is defined by the concentration of $\mathrm{Na}^{+}$in the ionomer normalized by the concentration of the sulfonic acid chains. As shown in fig. 3.7, relative $\mathrm{Na}^{+}$occupancy is mostly concentrated in CCL and varies from $98 \%$ to $40 \%$ from GDL to PEM side of CCL, and it monotonically decreases across the membrane and towards the anode. $\mathrm{Na}^{+}$ transport in the MEA is governed by both diffusion due to concentration gradient and migration due to the potential gradient. As electrolyte phase potential has a negative slope from anode to cathode (Fig. 3.6), migration always drives cations from anode to cathode, while diffusion drives in opposite direction because in this case, cation is introduced through the cathode. As migration moves cations from anode to cathode and the foreign cations are introduced through the cathode side, the foreign cations accumulate in the CCL.

Proton transport has a strong dependence on the water content in Nafion membranes. Nafion can conduct protons only in the presence of water, and proton conductivity decreases with a decrease in the level of hydration of the membrane. ${ }^{19}$ Fig. 3.8 shows the membrane water content profile across the MEA thickness. It is assumed that relative humidity in ACL/GDL interface and CCL/GDL interface is $80 \%$ and $100 \%$, 
respectively, which correspond to water content of 7.2 and 14 (using Eq. 14), respectively. In no contamination case, water content varies from 7.1 to 13.1 from ACL to CCL, linearly increasing in the anode to cathode direction. In the contaminated case, water content decreases throughout the MEA thickness. It decreases sharply in the CCL and membrane, and the decrease in water content is very low in the ACL. The reason behind the decrease in water content is mainly due to presence of $\mathrm{Na}^{+}$in the ionomer. $\mathrm{Na}^{+}$ occupancy is higher in the CCL and the membrane (Fig. 3.7). Moreover, the decrease in water content can be attributed to the reduction in the ionic hydration capacity and hydration energy, increase in size of counter cation, and the decrease in membrane swelling. ${ }^{18}$ The hydration energy for $\mathrm{Na}^{+}(-428.02 \mathrm{~kJ} / \mathrm{mol})$ is much lower than that of $\mathrm{H}^{+}$ $(-1087.84 \mathrm{~kJ} / \mathrm{mol})$. So, polar ends of water are loosely attached with $\mathrm{Na}^{+}$cation compared to $\mathrm{H}^{+} .{ }^{18}$ On the other hand, $\mathrm{Na}^{+}$strongly interacts with ionic cluster in Nafion membrane which reduced the chains mobility and the polymer becomes stiffer. ${ }^{30}$ So in case of $\mathrm{Na}^{+}$form membrane, Young's modulus increases and degree of pliability of the membrane becomes lower compared to $\mathrm{H}^{+}$form membrane, which impedes the swelling of membrane and results in lower water uptake. ${ }^{31}$ Tortuosity factor, which represents the lengthening of path of water transport is related to the polymer volume fraction and the nature of cations. Membrane with $\mathrm{Na}^{+}$has high tortuosity compared to the membrane in $\mathrm{H}^{+}$form. ${ }^{20}$ So, water diffusivity also decreases with the presence of $\mathrm{Na}^{+}$in the membrane.

Fig. 3.9 shows the gas phase and the dissolved oxygen concentration profile in the CCL for no contamination and contamination case. As concentration of $\mathrm{Na}^{+}$in the fluid phase is not considered directly, there is no change in gas phase oxygen concentration due to contamination. Dissolved oxygen concentration in contamination case varies from 
GDL to PEM side in CCL as $\mathrm{Na}^{+}$occupies $40 \%$ to $98 \%$ sulfonic acid sites of CCL (Fig. 3.7) and the exchange of $\mathrm{H}^{+}$with $\mathrm{Na}^{+}$in the ionomer decreases the oxygen diffusivity ${ }^{25}$ and the reaction rate (Eq. 27). It is found that the dissolved oxygen concentration in contamination case in the CCL close to the GDL (between 48-50 micron) is larger than the no contamination case. It can be explained by the following expression of current density which is obtained combining Eq. (19-21)

$\mathrm{i}=\frac{\mathrm{j}_{\mathrm{c}}}{4 \mathrm{~F}}=\left(\frac{\mathrm{a}_{\mathrm{agg}} \mathrm{D}_{\mathrm{O}_{2}}^{\mathrm{m}}}{\mathrm{AE} \delta_{\mathrm{agg}}} \frac{\mathrm{r}_{\mathrm{agg}}}{\mathrm{r}_{\mathrm{agg}}+\delta_{\mathrm{agg}}}\right)\left(\frac{\mathrm{RT}}{\mathrm{K}_{\mathrm{O} 2}} \mathrm{C}_{\mathrm{O}_{2}}^{\mathrm{g}}-\mathrm{C}_{\mathrm{O}_{2}}^{\mathrm{m}}\right)$

As $\mathrm{Na}^{+}$occupies $93 \%$ to $98 \%$ sulfonic acid sites of CCL close to the GDL (between 48 50 micron) (Fig. 3.7), the region is not active because proton conductivity is very low. So, current density is very low in that region. From Eq. 32, it can be said that as the current density decreases, the dissolved $\mathrm{O}_{2}$ concentration increases in that region.

Another important parameter that is affected by contamination is thermodynamic (equilibrium) potential. Equilibrium potential is calculated using Nernst equation (Eq. 30) and it is sensitive to proton concentration. Fig. 3.10 shows the equilibrium potential for no contamination and contamination case. In the CCL, potential drops from $18 \mathrm{mV}$ to $100 \mathrm{mV}$ because $\mathrm{H}^{+}$concentration decreases from $40 \%$ to $98 \%$ due to $\mathrm{Na}^{+}$contamination (Fig. 3.7), while in the ACL, contamination level is low and potential change is negligibly small. Lower equilibrium potential increases the surface overpotential and decreases proton generation and consumption rate (Eq. 26 and 27) decreasing the protonic current density. 


\subsection{Summary and Conclusions}

In this chapter, effect of cation $\left(\mathrm{Na}^{+}\right)$contamination is studied on four different factors: cation transport, water transport, oxygen transport, and equilibrium potential. Due to contamination, each parameter contributes to a decrease in protonic current density and combined effects of all these parameters result in decrease of current density from $0.72 \mathrm{~A} / \mathrm{cm}^{2}$ to $0.25 \mathrm{~A} / \mathrm{cm}^{2}$. Largest effect is found to be caused by decrease in effective proton transport due to foreign cations. Reasons behind the decrease in current density are listed below:

a. Foreign cations displace protons and occupy sulfonic acid sites. Cation concentration mostly concentrated in the CCL.

b. Foreign cation causes serious water depletion in the ionomer due to a decrease in the water diffusivity and equilibrium water uptake in the membrane.

c. It decreases the oxygen diffusivity causing a decrease in dissolved oxygen concentration in the CCL.

d. Presence of foreign cation also decreases equilibrium potential mostly in the cathode. 


\title{
List of Symbols
}

\author{
a water activity \\ $\mathrm{a}_{\mathrm{ac}}$ active surface area within the agglomerate, $\mathrm{m}^{-1}$ \\ $\mathrm{a}_{\text {agg }}$ total external area of active sites of agglomerate per unit volume of CL, $\mathrm{m}^{-1}$ \\ A total active area of agglomerate per unit volume of CL, $\mathrm{m}^{-1}$ \\ C molar Concentration, $\mathrm{mol} / \mathrm{m}^{3}$ \\ $\mathrm{C}_{\mathrm{so}_{3}^{-}}=\frac{\rho}{\mathrm{EW}}$ molar concentration of the sulfonic acid chains, $\mathrm{mol} / \mathrm{m}^{3}$ \\ D diffusion coefficient, $\mathrm{m}^{2} / \mathrm{s}$ \\ E effectiveness factor \\ EW equivalent weight of the membrane, $\mathrm{kg} / \mathrm{mol}$ \\ f mass fraction of platinum to that of $\mathrm{Pt} / \mathrm{C}$ particles \\ F faraday constant, $\mathrm{C} / \mathrm{mol}$ \\ I current density, $\mathrm{A} / \mathrm{m}^{2}$ \\ j transfer current, $\mathrm{A} / \mathrm{m}^{3}$ \\ $\mathrm{k}$ reaction rate constant, $\mathrm{m} / \mathrm{s}$ \\ $\mathrm{K}$ henry's law constant, $\mathrm{Pa} / \mathrm{m}^{3} / \mathrm{mol}$ \\ L MEA thickness \\ $\mathrm{N}$ mass flux \\ n no of species \\ $\mathrm{n}_{\mathrm{agg}}$ number of agglomerates per unit volume of CL, $\mathrm{m}^{-3}$ \\ $\mathrm{n}_{\mathrm{d}}$ electro-osmotic drag coefficient \\ $\mathrm{P}$ pressure, $\mathrm{Pa}$
}


$\mathrm{R}$ universal gas constant, $\mathrm{J} / \mathrm{mol} \mathrm{K}$

RH Relative humidity

$R_{j} \quad$ volumetric consumption of source term

$\mathrm{r}_{\text {agg }}$ agglomerate radius, $\mathrm{m}$

s liquid water saturation

S source term

T Temperature, ${ }^{\circ} \mathrm{C}$

$\mathrm{V}_{\text {cell }}$ cell voltage, $\mathrm{V}$

$\mathrm{V}_{\mathrm{p}} \quad$ volume fraction of polymer

$\mathrm{x}$ Distance, $\mathrm{m}$

$\mathrm{x}_{\mathrm{j}}$ species mole fraction

$\mathrm{x}_{\mathrm{cl}} \quad$ catalyst layer thickness, $\mathrm{m}$

$y_{j}=\frac{C_{j}}{C_{\mathrm{so}_{3}^{-}}} \quad$ relative cation occupancy of the sulfonic acid sites in the ionomer

z charge number

\section{Greek}

$\alpha$ net transfer coefficient

$\delta_{a g g} \quad$ ionomer film thickness, $\mathrm{m}$

$\varepsilon_{\mathrm{cl}} \quad$ effective porosity of catalyst layers

$\varepsilon_{\mathrm{mcl}}$ volume fraction of ionomer phase in catalyst layers

$\varepsilon_{\mathrm{gcl}}$ volume fraction of GDL penetrating into the CL

$\varepsilon_{\mathrm{GDL}} \quad$ GDL porosity

$\zeta$ stoichiometric flow ratio 
$\Phi$ potential, V

$\phi_{\mathrm{s}} \quad$ solid phase potential, $\mathrm{V}$

$\phi_{\mathrm{e}} \quad$ electrolyte phase potential, $\mathrm{V}$

$\eta \quad$ overpotential, $\mathrm{V}$

$\lambda$ water content

$\rho$ density, $\mathrm{kg} / \mathrm{m}^{3}$

$\rho_{\text {dry,m }}$ dry membrane density, $\mathrm{kg} / \mathrm{m}^{3}$

$\kappa$ ionic conductivity, $\mathrm{S} / \mathrm{m}$

\section{Subscripts}

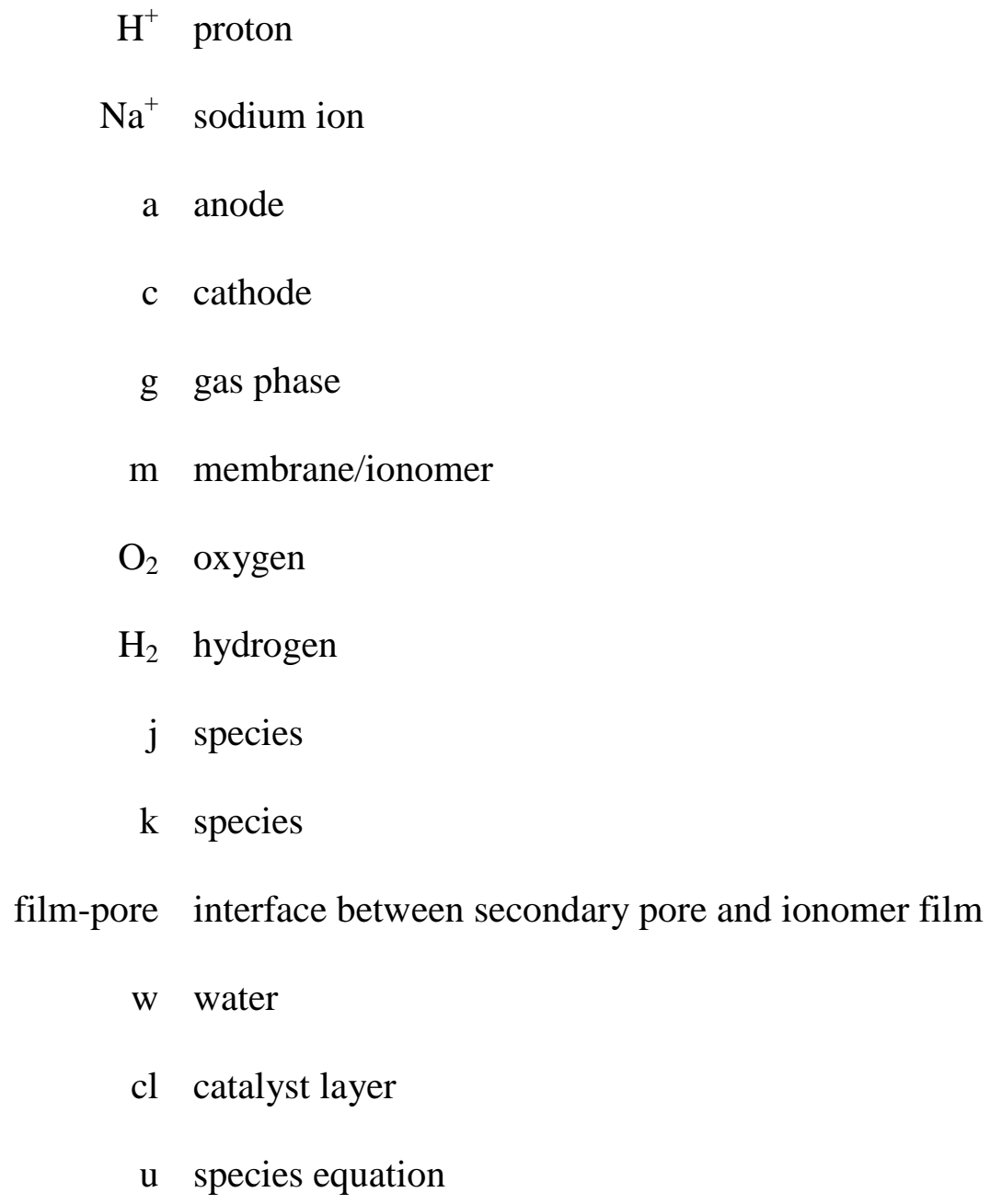


oc open circuit

\title{
Superscripts
}

\author{
aq aqueous \\ eq equilibrium \\ g gas phase \\ eff effective value \\ m membrane/ionomer \\ ref reference value \\ $\lambda$ ionomer phase \\ sat saturated condition
}




\subsection{References}

1. T. Okada, in Handbook of Fuel Cells-Fundamentals, Technology and Applications, W. Vielstich, H. A. Gasteiger, A. Lamm and H. Yokokawa, Editors, John Wiley \& Sons, Ltd, New York (2010).

2. T. Okada, J. Electroanal. Chem., 465, 1 (1999).

3. T. Okada, J. Electroanal. Chem., 465, 18 (1999).

4. B. Kienitz, H. Baskaran, T. Zawodzinski and B. Pivovar, ECS Trans., 11(1), 777 (2007).

5. B. Kienitz, H. Baskaran and T. Zawodzinski Jr, Electrochim. Acta., 54, 1671 (2009).

6. S. Sodaye, C. Agarwal and A. Goswami, J. Membr. Sci., 314, 221 (2008).

7. M. F. Serincan, U. Pasaogullari and T. Molter, Int. J. Hydrogen Energy, 35, 5539 (2010).

8. J. St-Pierre, Int. J. Hydrogen Energy, 36, 5527 (2011).

9. J. St-Pierre, J. power source, 196, 6274 (2011).

10. A. Z. Weber and C. Delacourt, Fuel Cells, 8, 459 (2008).

11. T. Greszler, T. Moylan and H. Gasteiger, in Handbook of Fuel Cells-Fundamentals, Technology and Applications, W. Vielstich, H. A. Gasteiger, A. Lamm and H. Yokokawa, Editors, John Wiley \& Sons, Ltd, New York (2010).

12. H. Meng, J. Power Sources, 168, 218 (2007).

13. R. Krishna and J. A. Wesselingh, Chemical Engineering Science, 52, 861 (1997).

14. E. Leonardi and C. Angeli, J. Phy.Chem. B, 114, 151 (2009).

15. T. E. Springer, T. Zawodzinski and S. Gottesfeld, J. Electrochem. Soc., 138, 2334 (1991).

16. H. Yasuda, C. E. Lamaze and L. D. Ikenberry, Die Makromolekulare Chemie, 118, 19 (1968).

17. A. Goswami, A. Acharya and A. Pandey, J. Phy. Chem. B, 105, 9196 (2001).

18. N. H. Jalani and R. Datta, J. Membr. Sci., 264, 167 (2005).

19. S. Motupally, A. J. Becker and J. W. Weidner, J. Electrochem. Soc., 147, 3171 (2000).

20. G. Suresh, S. Sodaye, Y. Scindia, A. Pandey and A. Goswami, Electrochim. Acta., 52, 5968 (2007).

21. N. Khajeh-Hosseini-Dalasm, M. Fesanghary, K. Fushinobu and K. Okazaki, Electrochim. Acta., 60, 55 (2012).

22. N. Khajeh-Hosseini-Dalasm, M. Kermani, D. G. Moghaddam and J. Stockie, Int. J. Hydrogen Energy, 35, 2417 (2010).

23. N. Khajeh-Hosseini-Dalasm, S. Ahadian, K. Fushinobu, K. Okazaki and Y. Kawazoe, J. Power Sources, 196, 3750 (2011).

24. K. Morohoshi and T. Hayashi, Polymers, 5, 56 (2013).

25. T. Sakai, H. Takenaka and E. Torikai, J. Electrochem. Soc., 133, 88 (1986).

26. Z. Ogumi, Z. Takehara and S. Yoshizawa, J. Electrochem. Soc., 131, 769 (1984).

27. H. Ju, H. Meng and C. Wang, Int. J. Heat Mass Transfer, 48, 1303 (2005).

28. H. Versteeg and W. Malalasekera, An Introduction to Computational Fluid Dynamics: The Finite Volume Method, p. 503, Pearson Education, Ltd, UK (2007).

29. M. S. Mikkola, T. Rockward, F. A. Uribe and B. Pivovar, Fuel cells, 7, 153 (2007).

30. S. Um, C. Wang and K. Chen, J. Electrochem. Soc., 147, 4485 (2000). 
31. Y. Kawano, Y. Wang, R. A. Palmer and S. R. Aubuchon, Polímeros, 12, 96 (2002).

32. R. Mann, J. Amphlett, B. Peppley and C. Thurgood, J. Power Sources, 161, 768 (2006).

33. A. Shah, G. Kim, P. Sui and D. Harvey, J. Power Sources, 163, 793 (2007).

34. T. Okada, H. Satou, M. Okuno and M. Yuasa, J. Phy.Chem. B, 106, 1267 (2002). 
Table 3.1. Governing equations in various regions.

Domain Conservation equation $\mathrm{Eq} \quad$ Source

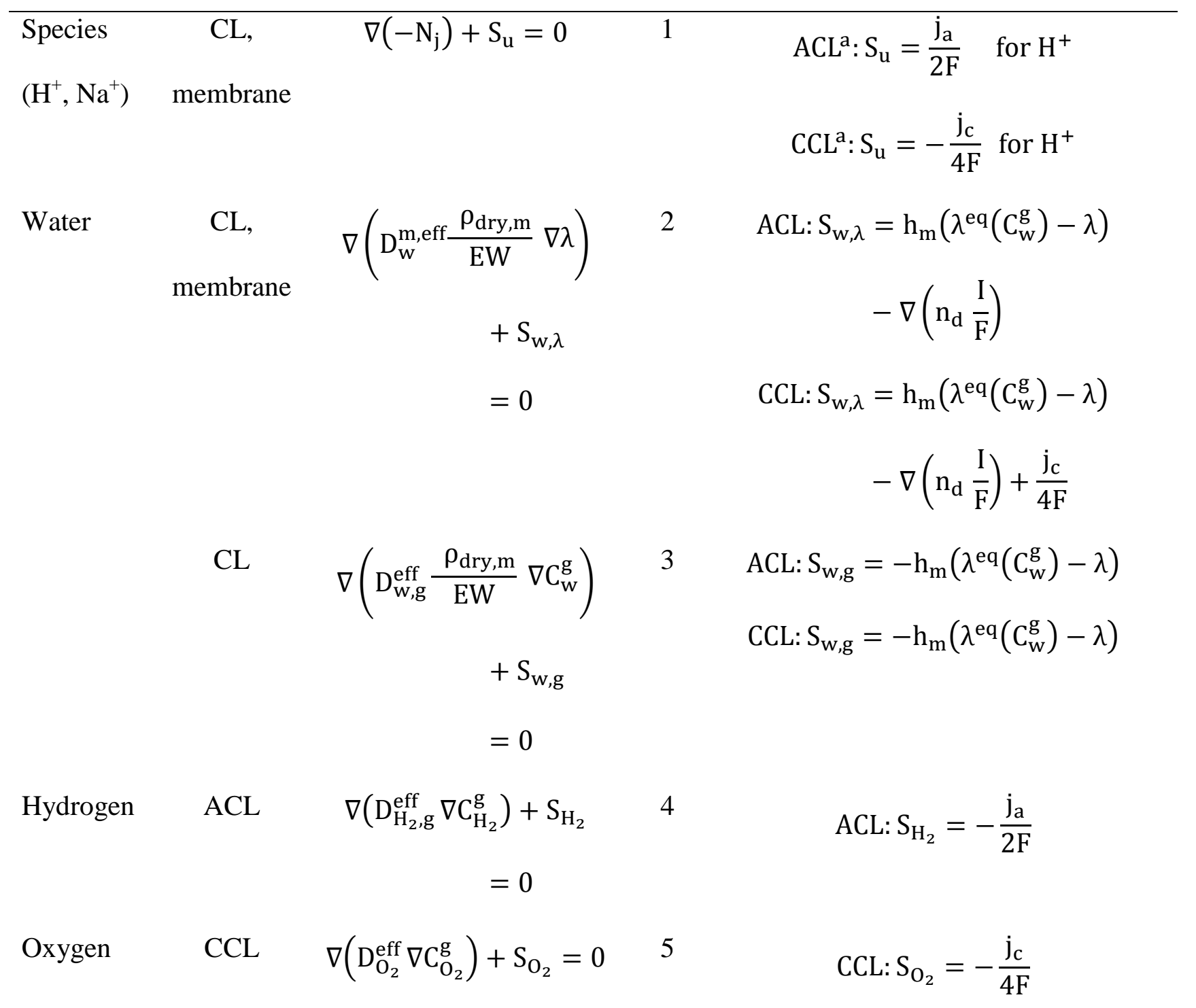

${ }^{\text {a }}$ Source term for $\mathrm{Na}^{+}$is zero.

-Effective mass diffusivity in porous media described using Buggerman relation $D_{i}^{\text {eff }}=\varepsilon^{1.5} D_{i}$ 
Table 3.2. Physical and electrochemical properties.

Description

Value

Ref.

Anode/cathode catalyst layer thickness, $\mathrm{x}_{1}$

$10 \mu \mathrm{m}$

Membrane thickness, $\left(\mathrm{x}_{2}-\mathrm{x}_{1}\right)$

$30 \mu \mathrm{m}$

Anode volumetric reference exchange current density, aj ref $_{0, a}^{\mathrm{ref}}$

$1 \times 10^{9} \mathrm{~A} / \mathrm{m}^{3}$

Cathode volumetric reference exchange current density, aj $j_{0, c}^{r e f}$

$3 \times 10^{3} \mathrm{~A} / \mathrm{m}^{3}$

Dry membrane density, $\rho_{\text {dry,m }}$

$1980 \mathrm{~kg} / \mathrm{m}^{3}$

Equivalent weight of electrolyte in membrane, EW

$1.1 \mathrm{~kg} / \mathrm{mol}$

Faraday constant, F

$96485 \mathrm{C} / \mathrm{mol}$

Universal gas constant, $\mathrm{R}$

8.314 J/mol.K

Cell Temperature, $\mathrm{T}$

$80{ }^{\circ} \mathrm{C}$

Effective porosity of anode/cathode catalyst layers, $\varepsilon_{\mathrm{cl}}$

0.4

Volume fraction of ionomer phase in catalyst layers, $\varepsilon_{\mathrm{mcl}}$

0.4

Anode transfer coefficients

$\alpha_{\mathrm{a}}=1$

27

Cathode transfer coefficient

$\alpha_{\mathrm{c}}=1$

27

$\mathrm{H}_{2} \mathrm{O}$ diffusivity in ACL, $\mathrm{D}_{\mathrm{w}, \mathrm{g}}$

$1.1028 \times 10^{-4} \mathrm{~m}^{2} / \mathrm{s}$

$\mathrm{H}_{2} \mathrm{O}$ diffusivity in CCL, $\mathrm{D}_{\mathrm{w}, \mathrm{g}}$

$7.35 \times 10^{-4} \mathrm{~m}^{2} / \mathrm{s}$

Reference hydrogen molar concentration, $\mathrm{C}_{\mathrm{H}_{2}}^{\mathrm{ref}}$

$40.88 \mathrm{~mol} / \mathrm{m}^{3}$

Reference oxygen molar concentration, $\mathrm{C}_{\mathrm{O}_{2}}^{\mathrm{m} \text {,ref }}$

$38.37 \mathrm{~mol} / \mathrm{m}^{3}$

$\mathrm{H}_{2}$ diffusivity in ACL, $\mathrm{D}_{\mathrm{H}_{2}, \mathrm{~g}}$

$1.1028 \times 10^{-10} \mathrm{~m}^{2} / \mathrm{s}$

27

$\mathrm{O}_{2}$ diffusivity in CCL, $\mathrm{D}_{\mathrm{O}_{2}, \mathrm{~g}}$

$3.2348 \times 10^{-10} \mathrm{~m}^{2} / \mathrm{s}$

$\mathrm{O}_{2}$ Hanry's constant, $\mathrm{K}_{\mathrm{O}_{2}}$

$2.641 \times 10^{3} \mathrm{~Pa} . \mathrm{m}^{3} / \mathrm{mol}$

32 
Cell Voltage, $\mathrm{V}_{\text {cell }}$

Relative humidity at anode, $\mathrm{RH}_{\mathrm{a}}$

Relative humidity at cathode, $\mathrm{RH}_{\mathrm{c}}$

Mass transfer coefficient, $\mathrm{h}_{\mathrm{m}}$

Electro-osmotic drag coefficient of water for $\mathrm{H}^{+}$ionomer, $\mathrm{n}_{\mathrm{d}}$

Electro-osmotic drag coefficient of water for $\mathrm{Na}^{+}$ionomer, $\mathrm{n}_{\mathrm{d}}$

Aqueous diffusion coefficient of $\mathrm{Na}^{+}, \mathrm{D}_{\mathrm{Na}^{+}}^{\mathrm{aq}}$

Self-diffusion coefficient of water, $D_{\mathrm{w}}^{\mathrm{aq}}$

Volume fraction of polymer in $\mathrm{Na}^{+}$form Nafion

Anode hydrogen concentration, $\mathrm{C}_{\mathrm{H}_{2} \text {-inlet }}^{\mathrm{g}}$

Cathode oxygen concentration, $\mathrm{C}_{\mathrm{O}_{2} \text {-inlet }}^{\mathrm{g}}$
$0.7 \mathrm{~V}$

$80 \%$

$100 \%$

$1 \times 10^{5}$

33

1

9.2

34

$2.6 \times 10^{-10} \mathrm{~m}^{2} / \mathrm{s}$

16

$5.1 \times 10^{-10} \mathrm{~m}^{2} / \mathrm{s}$

20

0.745

17

$40 \mathrm{~mol} / \mathrm{m}^{3}$

$20 \mathrm{~mol} / \mathrm{m}^{3}$ 
Table 3.3. Oxygen transport properties.

Description

Value

Ref.

Mass fraction of platinum to that of $\mathrm{Pt} / \mathrm{C}$ particles, $\mathrm{f}$

0.2

22

Liquid water saturation, $\mathrm{s}$

0.5

Agglomerate radius, $\mathrm{r}_{\text {agg }}$

$0.1 \mu \mathrm{m}$

Ionomer film thickness, $\delta_{\text {agg }}$

$1 \mathrm{~nm}$

Volume fraction of GDL penetrating into the CL, $\varepsilon_{\text {gcl }}$

0.1

GDL porosity, $\varepsilon_{\mathrm{GDL}}$

0.4

21

Oxygen diffusivity in $\mathrm{H}^{+}$form ionomer, $\mathrm{D}_{\mathrm{O}_{2}, \mathrm{H}^{+}}^{\mathrm{m}}$

$6 \times 10^{-11} \mathrm{~m}^{2} / \mathrm{s}$

25

Oxygen diffusivity in $\mathrm{Na}^{+}$form ionomer, $\mathrm{D}_{\mathrm{O}_{2}, \mathrm{Na}^{+}}^{\mathrm{m}}$

$1.96 \times 10^{-11} \mathrm{~m}^{2} / \mathrm{s} \quad 26$ 


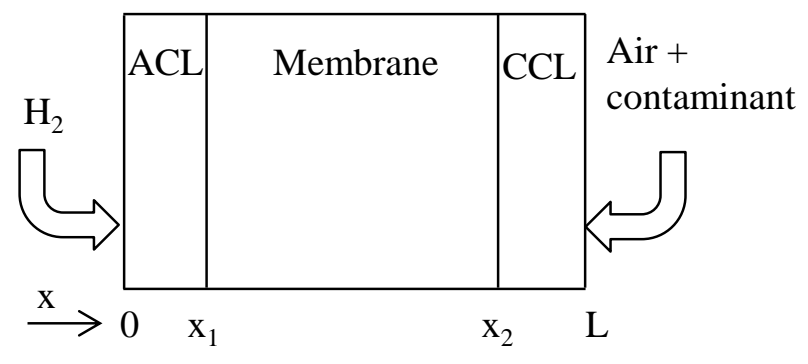

Fig. 3.1. Schematic diagram of MEA of polymer electrolyte fuel cell (PEFC). 


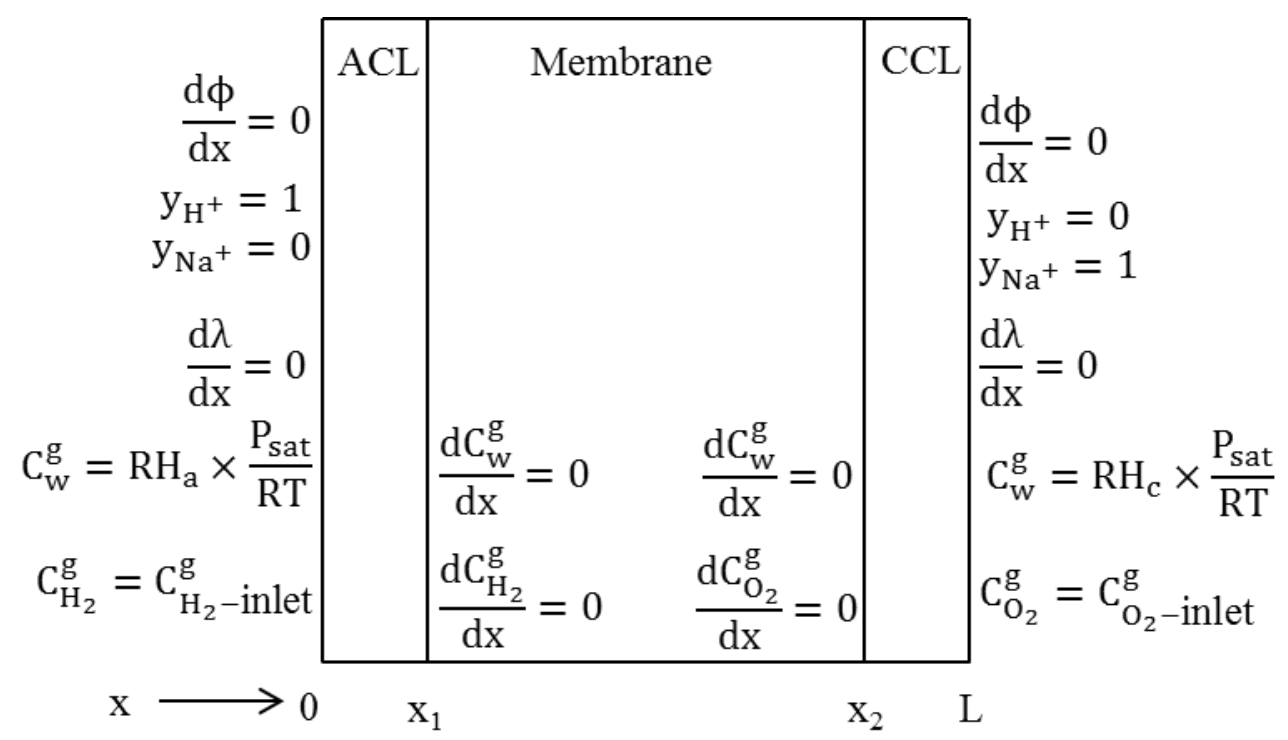

Fig. 3.2. Boundary conditions. 


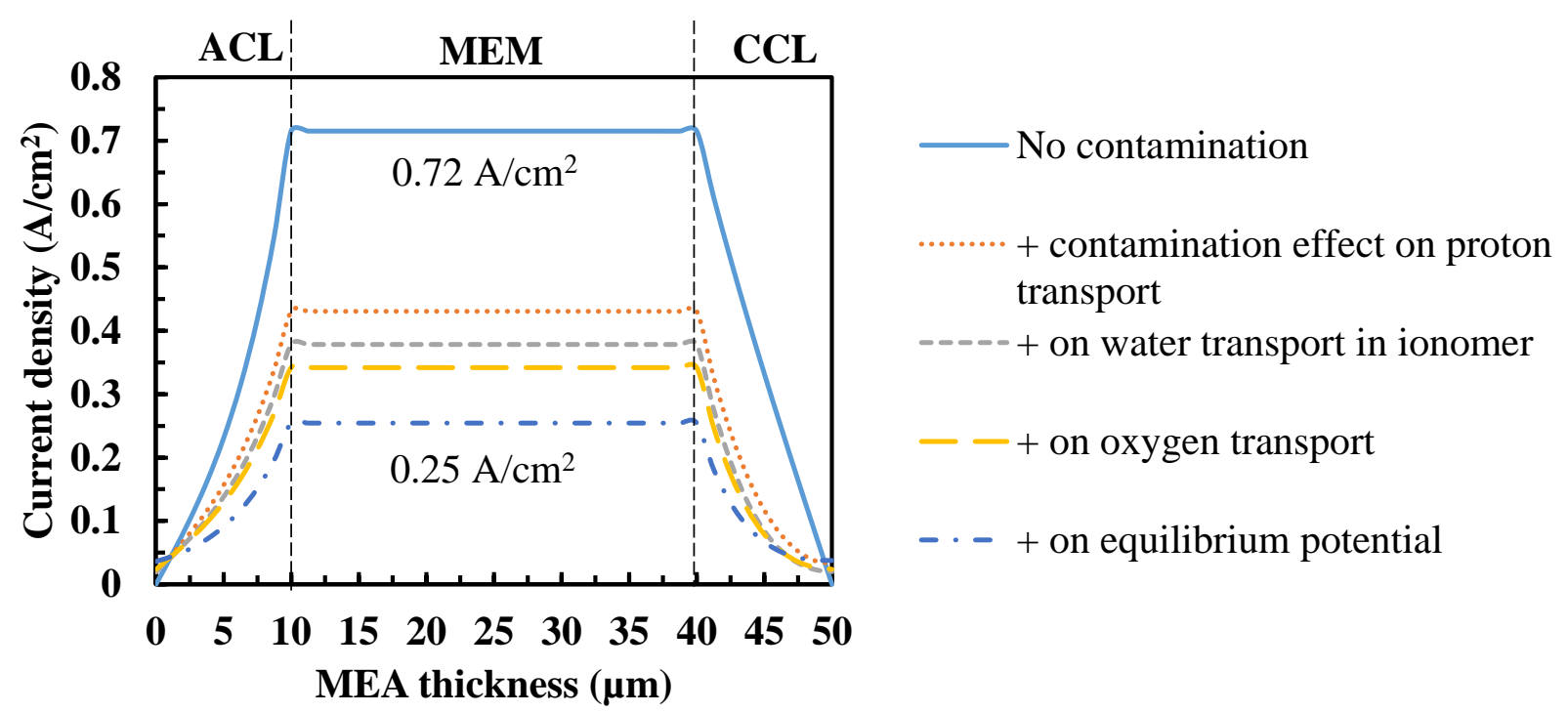

Fig. 3.3. Protonic current density distribution along MEA thickness. First, no contamination case is solved, and then one by one contamination is added to cation transport, water transport, oxygen transport, and Nernst equation. Operating conditions: cell voltage: $0.7 \mathrm{~V}$; $\mathrm{RH}$ anode/cathode: $80 \% / 100 \%$; cell temperature: $80^{\circ} \mathrm{C}$. 


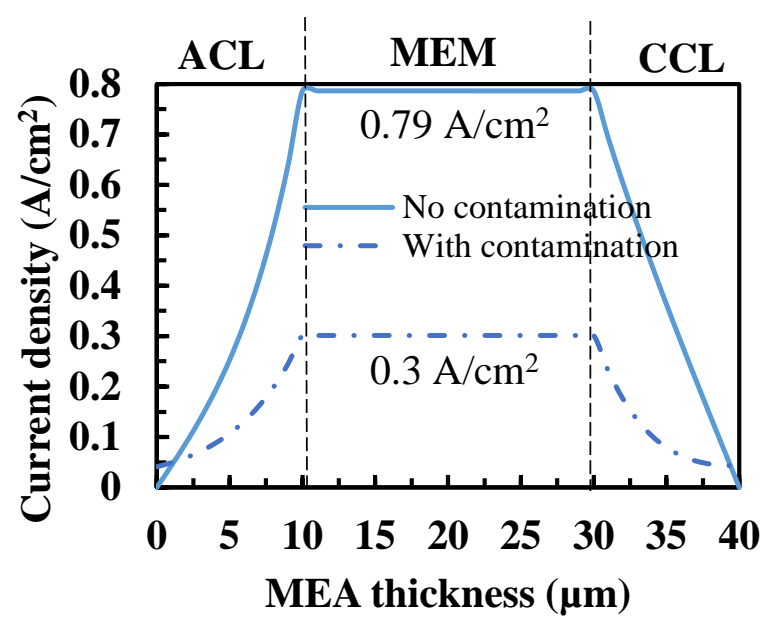

Fig. 3.4. Protonic current density distribution along MEA thickness for thinner membrane (20 $\mu \mathrm{m})$. Operating conditions: cell voltage: $0.7 \mathrm{~V}$; RH anode/cathode: $80 \% / 100 \%$; cell temperature: $80^{\circ} \mathrm{C}$. 


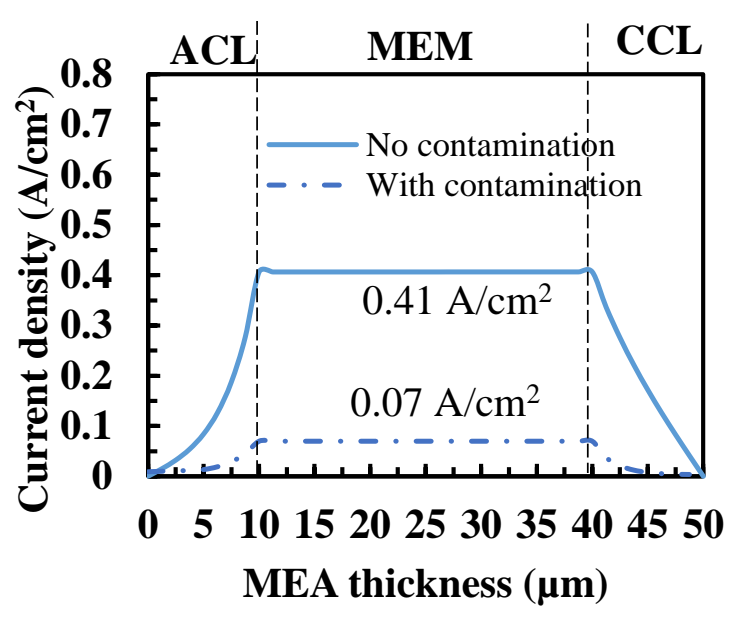

Fig. 3.5. Protonic current density distribution along MEA thickness for dry condition (50\% RH in anode and cathode). Operating conditions: cell voltage: $0.7 \mathrm{~V}$; cell temperature: $80^{\circ} \mathrm{C}$. 


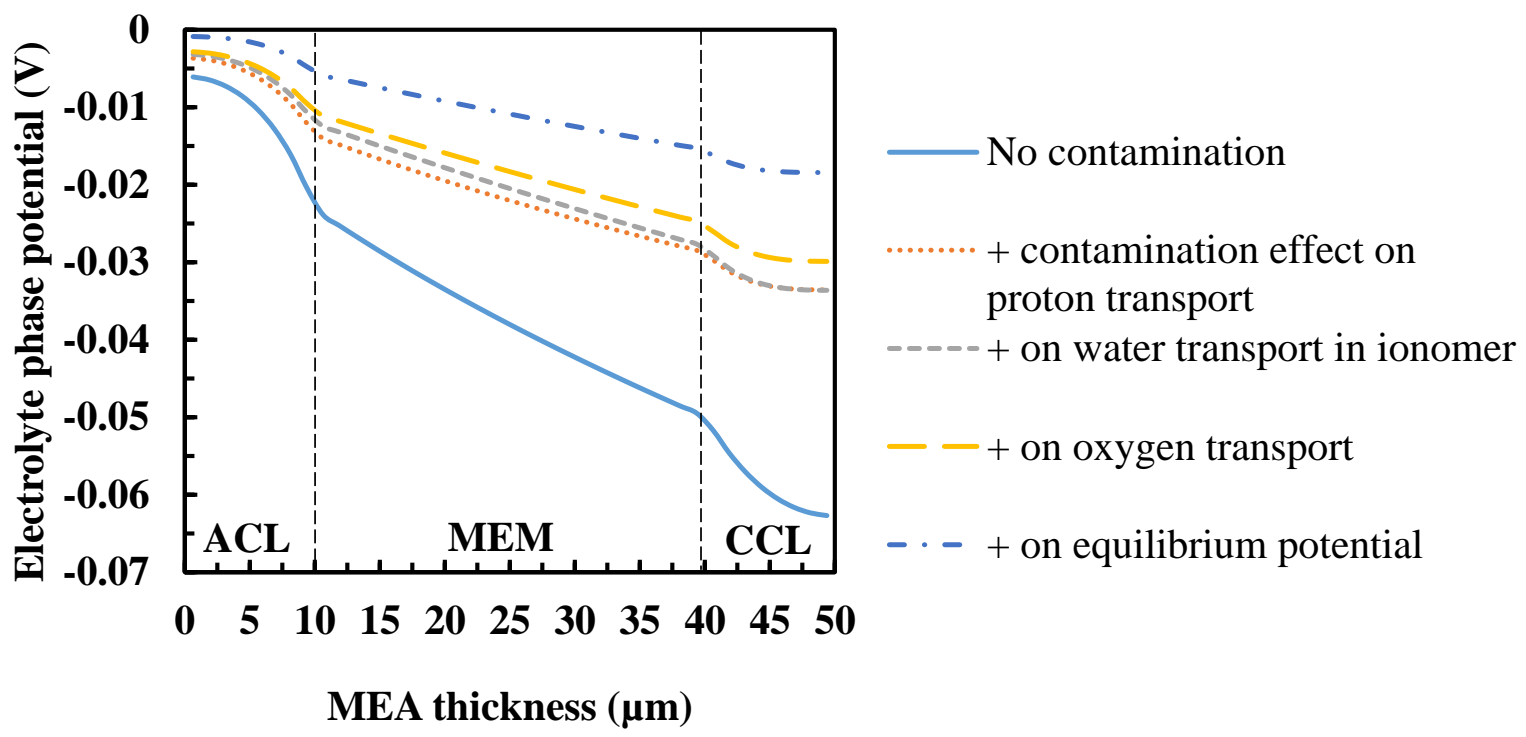

Fig. 3.6. Electrolyte phase potential distribution along MEA thickness. First, no contamination case is solved (current density $0.72 \mathrm{~A} / \mathrm{cm}^{2}$ ), and then one by one contamination is added to cation transport $\left(0.43 \mathrm{~A} / \mathrm{cm}^{2}\right)$, water transport $\left(0.38 \mathrm{~A} / \mathrm{cm}^{2}\right)$, oxygen transport $\left(0.34 \mathrm{~A} / \mathrm{cm}^{2}\right)$, and equilibrium potential $\left(0.25 \mathrm{~A} / \mathrm{cm}^{2}\right)$. Operating conditions: cell voltage: $0.7 \mathrm{~V}$; $\mathrm{RH}$ anode/cathode: $80 \% / 100 \%$; cell temperature: $80^{\circ} \mathrm{C}$. 


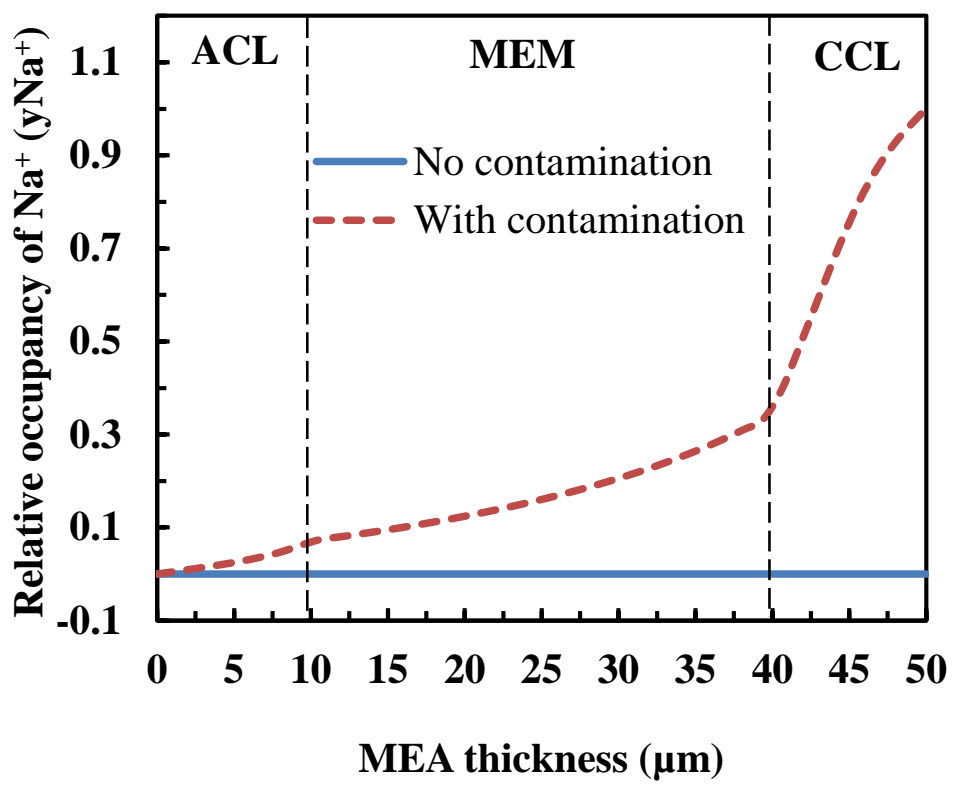

Fig. 3.7. Relative $\mathrm{Na}^{+}$occupancy across the MEA with and without contamination in the air stream. The uptake of $\mathrm{Na}^{+}$is assumed 1 at CCL and cathode GDL interface. Operating conditions: cell voltage: $0.7 \mathrm{~V}$; RH anode/cathode: $80 \% / 100 \%$; cell temperature: $80^{\circ} \mathrm{C}$. 


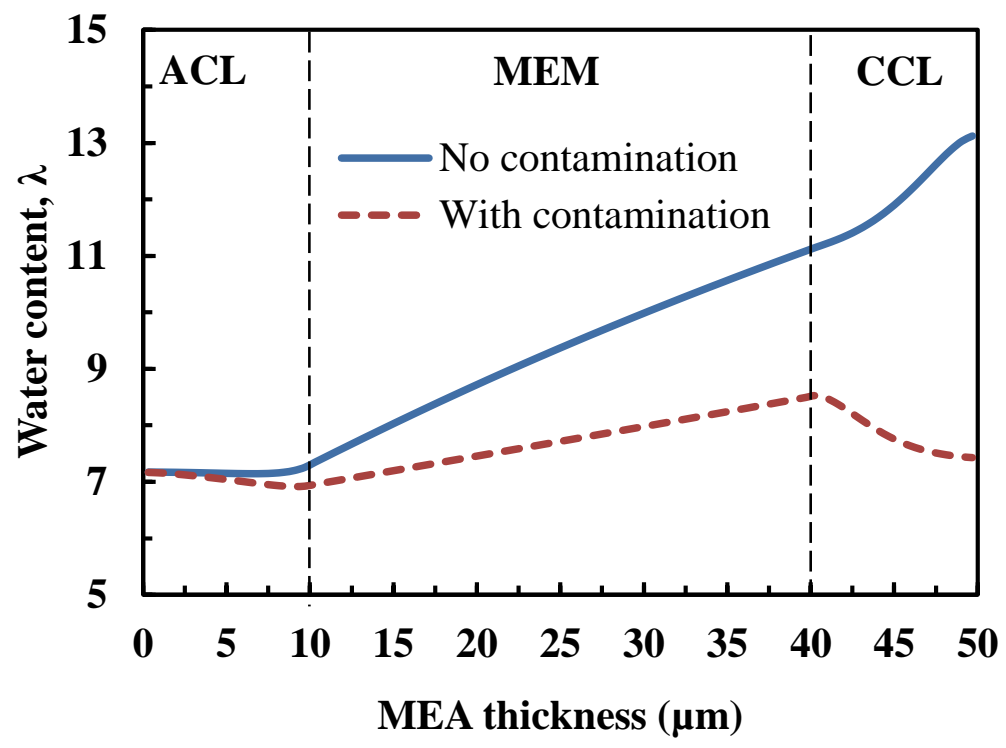

Fig. 3.8. Water content profile along MEA thickness when there is no contamination and contamination is in the air stream. Operating conditions: cell voltage: $0.7 \mathrm{~V} ; \mathrm{RH}$ anode/cathode: $80 \% / 100 \%$; cell temperature: $80^{\circ} \mathrm{C}$. 


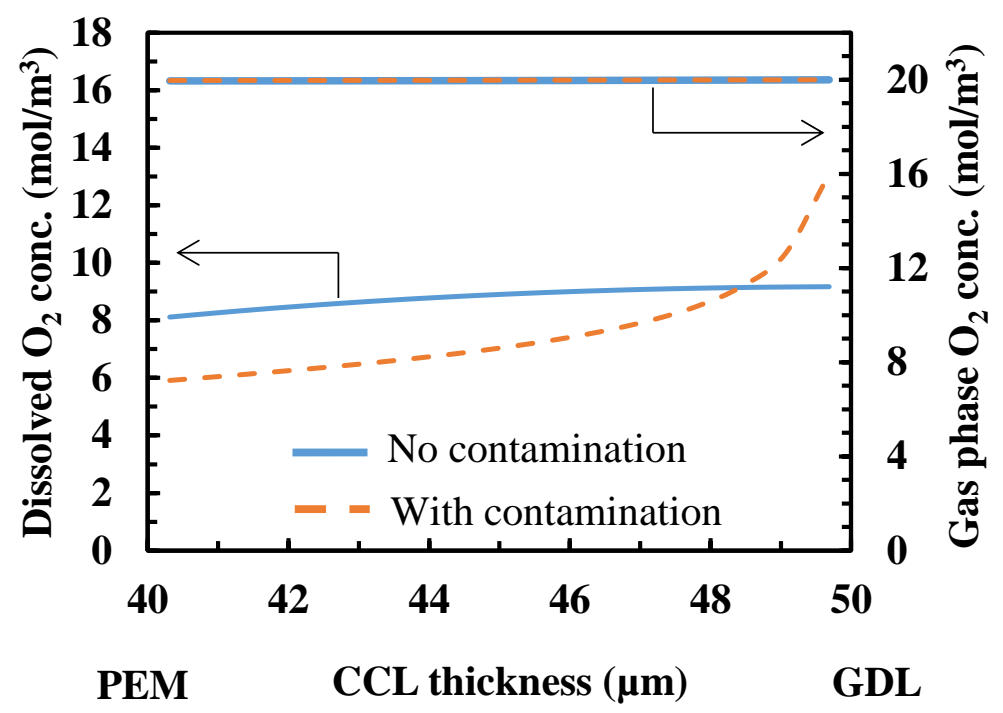

Fig. 3.9. Gas phase and dissolved oxygen concentration profile in CCL. Operating conditions: cell voltage: $0.7 \mathrm{~V}$; $\mathrm{RH}$ anode/cathode: $80 \% / 100 \%$; cell temperature: $80^{\circ} \mathrm{C}$. 


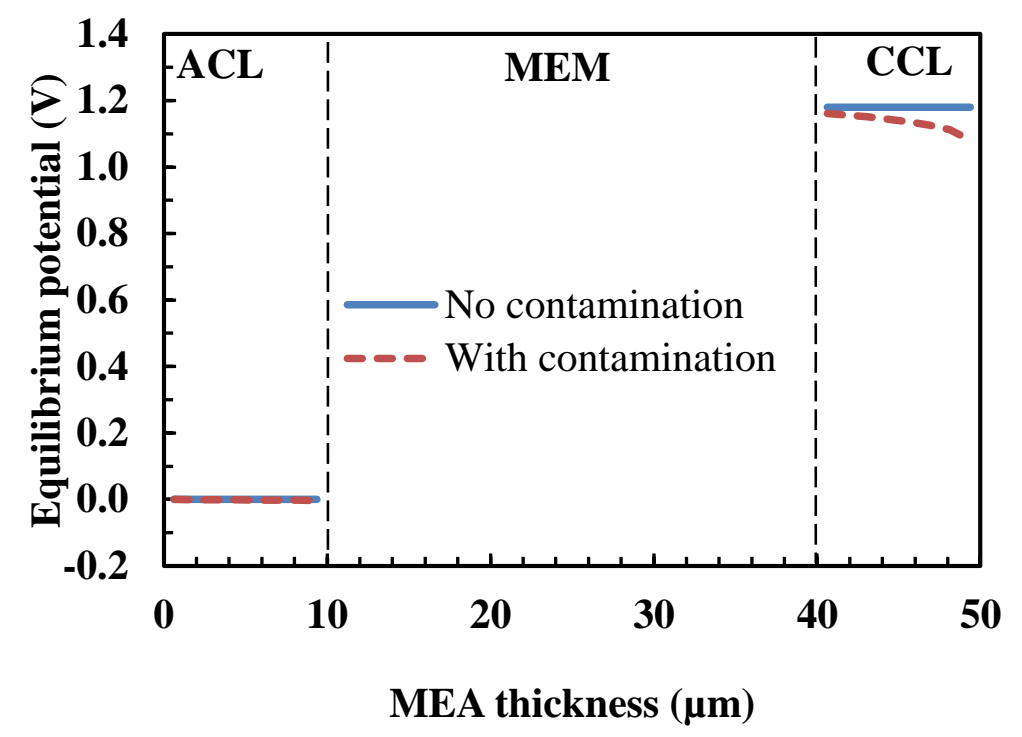

Fig. 3.10. Equilibrium potential using standard Nernst equation (Eq. 30). 


\section{DISTRIBUTED CATION CONTAMINATION FROM \\ CATHODE TO ANODE DIRECTION IN POLYMER \\ ELECTROLYTE FUEL CELLS}

\subsection{Introduction}

Since Nafion has higher affinity to cation than proton, cation replaces proton and occupies the sulfonic acid site. ${ }^{1-4}$ As shown in chapter 3 , during fuel cell operation, any cationic contaminants will form a concentration gradient and tend to accumulate in the cathode. Moreover, our group investigated the effect of different cations $\left(\mathrm{Na}^{+}, \mathrm{K}^{+}, \mathrm{Mg}^{2+}\right.$, $\left.\mathrm{Ca}^{2+}, \mathrm{Ni}^{2+}, \mathrm{Ba}^{2+}, \mathrm{Al}^{3+}, \mathrm{Cr}^{3+}, \mathrm{Fe}^{3+}\right)$ combined with different anions $\left(\mathrm{Cl}^{-},\left(\mathrm{ClO}_{4}\right)^{-}\right.$and $\left.\left(\mathrm{SO}_{4}\right)^{2-}\right)$ injected into the air stream of an operating fuel cell. ${ }^{5-8}$ When injected into the cell along with the air stream, we observed that cationic salts can deposit on the flow field and the GDL surface causing significant mass transport losses. Certain salt solutions can also penetrate into the GDL and reached to the CCM, indicating a need for a study of the through plane distribution of cationic contamination on PEFC.

To study the effect of cationic contamination in the through plane, a special membrane electrode assembly (MEA) was prepared with five layers of membrane (NRE 211) equipped with four Pt wires. As the contaminant, $\mathrm{CaSO}_{4}$ solution was introduced in the air stream of the fuel cell. A similar cell design was used by Watanabe et al. to measure through plane water content distribution, ${ }^{9-11}$ hydrogen and oxygen permeation ${ }^{12}$ and the transient behavior of specific resistance during the load change. ${ }^{13}$ According to 
our search of the open literature, this is the first time this type of MEA was used for the analysis of the contamination effect.

\subsection{Experimental}

Nafion® membrane (NRE 211, Ion Power Inc.) was first treated with $500 \mathrm{mM}$ Sulfuric acid solution at $80^{\circ} \mathrm{C}$ for 6 hours. Then the membrane was thoroughly washed in DI water and kept in DI water for overnight. The membrane was thermally flattened with the following process: the membrane was sandwiched between $25 \mu \mathrm{m}$ thick Teflon films, and carbon plates and rubber sheets were placed on both side of the Teflon films. Then the membrane sandwich was placed in the hot press and kept for 1 hour at $80^{\circ} \mathrm{C}$ with no applied pressure. The nominal thickness of each membrane was $25 \mu \mathrm{m}$. Four Pt wire electrodes (diameter $50 \mu \mathrm{m}$, Alfa Aesar, USA) were inserted between five layers of treated Nafion ${ }^{\circledR}$ membranes and placed over the active area from the inlet to the outlet of the cell as shown in Fig. 4.1. The Pt wire electrode close to the anode (E1) was placed $1 \mathrm{~cm}$ below the gas inlet to the active area and all other electrodes (E2, E3, and E4) were placed approximately $1 \mathrm{~cm}$ apart from each other. In all electrochemical measurements, anode electrode was taken as the reference.

The membranes equipped with $\mathrm{Pt}$ wires were sandwiched between two gas diffusion electrodes (GDEs) (FuelCellsEtc, College Station, TX, USA). The GDE (thickness of $410 \mu \mathrm{m}$ ) consisted of carbon cloth GDL/microporous layer (MPL)/catalyst layer. Catalyst layers were made of Pt black with $4 \mathrm{mg} / \mathrm{cm}^{2}$ loading. The whole arrangement shown in Fig. 4.1 was hot pressed at $130{ }^{\circ} \mathrm{C}$ for $50 \mathrm{~min}$ at a pressure of 4.5 MPa. After compression, total thickness of the MEA with GDEs was $900 \mu \mathrm{m}$. 
The single-cell hardware consisted of an aluminum alloy anode flow field, an aluminum alloy cathode flow field, and two aluminum end plates. Both flow fields consisted of 5 straight flow channels with $1.0 \mathrm{~mm}$ width, $1.0 \mathrm{~mm}$ channel depth and $1.0 \mathrm{~mm}$ landing. To prevent corrosion and contamination, all the aluminum parts were gold plated and before gold plating, a thin nickel adhesion layer was applied on aluminum parts. The active area of the cell was $5 \mathrm{~cm}^{2}$.

The details of the experimental setup and experimental procedures are mentioned in elsewhere. ${ }^{6,8}$ Calcium sulfate $\left(99.99 \%\right.$ pure, Sigma-Aldrich ${ }^{\circledR}$, St. Louis, MO, USA) solution was injection into the air stream of the fuel cell as a contaminant through a nebulizer (ES-2005, PFA-400, Elemental Scientific Inc., Omaha, NE, USA) and a high resolution HPLC pump (Series III Pump, Scientific Systems Inc., State College, PA, USA). The flow rate of the Calcium sulfate solution was $65 \mu \mathrm{Lmin}$ with a concentration of $1.14 \mathrm{mM}$ which corresponds to $5 \mathrm{ppm}$ flow in air stream on mole basis.

An electrochemical impedance spectroscopy (EIS) test was carried out with a potentiostat/galvanostat (Solartron SI 1260). The EIS was measured from $100 \mathrm{kHz}$ to $0.1 \mathrm{~Hz}$ with an $\mathrm{AC}$ amplitude of $5 \mathrm{~mA}$, which was small compared to the cell current $(1000 \mathrm{~mA})$ to ensure that the response is linear. The real component of impedance (Re $(Z))$ at the high frequency region of EIS was taken as the high frequency resistance (HFR) where imaginary component of the impedance is zero $(\operatorname{Im}(Z)=0)$.

After the test, the cell was disassembled and the contaminated MEA was characterized by scanning electron microscope (SEM) and energy dispersive X-ray spectroscopy (EDX) analysis (FEI Quanta 250, FEI, Hillsboro, OR, USA). Some analyses were also conducted with micro-computed tomography (Micro XCT, Xradia 
Ultra XRM-L400, Xradia, Inc. Pleasanton, CA, USA). Using Xradia's MicroXCT system, a tomography of the GDL with precipitated salts was obtained. This system utilized geometric and optical magnification in the region of interest in order to resolve the individual features of the carbon fibers and salt deposits. Exploiting the differences in the attenuation coefficients, the X-ray photon energy was optimized such that sufficient contrast between the individual components (air, carbon and salt deposits) was observed to segregate each material. Using the commercial software Avizo (FEI, Hillsboro, OR, USA), the reconstructed tomography data was imported and rebuilt. To separate the salt voxels from carbon and air, analysis of the pixel histograms was used to resolve pixel values to determine the thresholds for individual constituents of the sample. Tertiary segmentation of the tomography using the previously obtained threshold values was used to visualize the salt deposits in the sample.

\subsection{Results and discussion}

\subsubsection{Cell performance}

Fig. 4.2 shows the cell voltage measured with time at a fixed current density of $200 \mathrm{~mA} / \mathrm{cm}^{2}$. At first, the cell was run for 55 hours without contaminant injection. During this period, a voltage drop of $113 \mathrm{mV}$ was observed. After 55 hours of baseline testing, $\mathrm{CaSO}_{4}$ solution injection was started. During this period, the cell voltage decreased rapidly, and within 21 hours of contamination, cell voltage became less than $200 \mathrm{mV}$. Then contaminant injection was stopped for recovery; however, the cell voltage did not recover and decreased further. When the cathode air flow was increased by $200 \mathrm{sccm}$, the cell voltage started to increase and at some point it suddenly dropped to zero. The reason 
behind the performance degradation is explained later. It should be noted that there were several discontinuities in the plot; EIS was measured at those times.

After the test, the cell was disassembled and postmortem analyses were done. A significant amount of white deposit was observed on both the cathode GDE and the flow field surface. Fig. 4.3 shows the secondary electron image of the cathode GDE surface which clearly shows the salt deposit on GDE. These salt deposits contained calcium, sulfur, oxygen, aluminum, and nickel as detected by EDX spectra and the elemental maps (Fig. 4.3). Since $\mathrm{CaSO}_{4}$ solution was injected during the test, it is reasonable to detect $\mathrm{Ca}$, $\mathrm{S}$ and $\mathrm{O}$. Aluminum and nickel probably come from the sub-surface of gold coated aluminum alloy flow field, where there was a nickel adhesion layer on the surface under the gold coating. These results confirm that the aluminum flow field was corroded and also contaminated the cell. After the test, inspection showed that some of the gold layer had lifted off of the flow field and there was some evidence of micro-cracks in the gold coating on aluminum flow field, which were enough to allow the corrosion of aluminum. ${ }^{14}$ Moreover, on the gold plated aluminum flow field, two dissimilar materials $\left(\mathrm{Al}\right.$ and $\mathrm{Au}$ ) with a galvanic potential difference ${ }^{15}$ were in contact in presence of calcium sulfate as the electrolyte which would allow a micro-galvanic cell on the surface of the flow field and galvanic corrosion. In either case, post-test inspection shows that the gold plated aluminum flow field was corroded in the presence of moist air (125\% RH) and calcium sulfate solution. So, although no contamination was injected into the cell during first 55 hours of the test (Fig. 4.2), the cell was contaminated with the corrosion products of the gold plated aluminum alloy flow field corrosion resulting in a significant voltage drop during the baseline test. When the calcium sulfate solution was injected, the cell 
performance became significantly worse causing salt deposit which blocked some of the flow channels and barred air transport causing mass transport losses. As a result, the cell voltage became close to zero. When air flow was increased, mass transport loss was reduced and the cell voltage was started to increase. Finally, the cell failed due to high internal shorting between anode and cathode. Although the cell failed showing symptoms similar to internally shorted cell, this could also be caused by complete flow field blockage.

The cross-section of the MEA was also analyzed using SEM/EDX. No cations were detected in the membrane; however different cations (calcium, aluminum and nickel) might have penetrated the membrane, but they were below the EDX detection limit. Even though the MEA was contaminated by three different cations, our qualitative findings (next section) are unaffected, since they are all positively charged and migrate similarly under the potential field.

Fig. 4.4a shows the 3D representation of a portion of cathode GDE which was obtained with micro XCT. In Fig. 4.4b, salt deposit was segmented from the fiber. Similar to our previous tests, ${ }^{6,8}$ salt deposited on GDE surface and entered into the GDE, but it was mostly concentrated on the top of the GDE.

\subsubsection{Through plane contamination effect}

Pt wires inside the membrane layers act as electrodes. Any presence of hydrogen or oxygen at the Pt electrode reacts very fast and gives the following reactions:

$$
\begin{aligned}
& \frac{1}{2} \mathrm{O}_{2}+2 \mathrm{H}^{+}+2 \mathrm{e}^{-} \rightarrow \mathrm{H}_{2} \mathrm{O} \\
& \mathrm{H}_{2} \rightarrow 2 \mathrm{H}^{+}+2 \mathrm{e}^{-}
\end{aligned}
$$


Fig. 4.5 shows the distribution profile of mixed potential along the membrane thickness at the beginning of the test (BoT) for different current densities. For all cases, electrode 4 (E4), which was closest to the cathode, shows similar to the cathode voltage as oxygen permeated from the cathode to the E4 region. So, in E4, potential was dominated by Eq. (1). In electrode 3 (E3), a very low voltage was observed probably due to the limited permeation of oxygen from cathode. Electrode 1 (E1) which was close to anode showed a zero potential. It can be expected that in E1 region, hydrogen permeated from anode, but oxygen permeated from cathode side was not enough to contribute to the mixed potential. So, E1 potential was dominated by Eq. (2). Similarly, Electrode 2 (E2) voltage was also close to zero. It should be mentioned that anode was taken as the reference electrode in all voltage measurement.

Fig. 4.6 shows the through plane voltage change with time. E4 voltage closely followed the cell voltage during baseline test. At the beginning of the contaminant injection, there was larger voltage drop in E4 compared to the cell voltage and in rest of the test, it maintained a gap with the cell voltage, but it followed the same trend. In case of E1, E2, and E3, voltages remained zero until 32 hours; hence, up to 32 hours, oxygen permeation from cathode to these electrode positions remained negligibly small. E1 voltage remained zero throughout the test. E2 showed a measurable voltage after 40 hours and then it followed the same trend as the cell voltage. In case of E3, after 32 hours voltage started to increase during baseline test. E3 was found broken after disassembly (Fig. 4.7); therefore we do not consider the voltage measurement for E3 very reliable. As a result, measurements from E3 were not shown in the plot. For other electrodes, membrane degradation might have started after 32 hours resulting in increased 
permeation of oxygen. As contaminant started to deposit on the GDE surface with time (Fig. 4.3), it impeded the oxygen transport. As a result, potential in all electrodes decreased with the cell voltage.

Fig. 4.8 shows the distribution profile of mixed potential for various current densities at the end of the test (EoT). For all the cases, E1 voltage remained zero and for all other electrodes the potential increased linearly from the anode to the cathode. These again clearly represented permeation of oxygen from the cathode to the anode. Moreover, voltages are lower for the same locations at $\mathrm{OCV}$ and at $100 \mathrm{~mA} / \mathrm{cm}^{2}$ compared to the measurements at the beginning of the contamination test (shown in Fig. 4.5). The change in probe potential is mostly due to salt deposition on GDE and flow field surface that impede the oxygen transport. It can also be related to the change in water content induced by the presence of foreign cations. Generally, the presence of foreign cations decreases the membrane water content. ${ }^{1,3}$ Additionally, gas permeability is also a function of water content as reactants usually follow the hydrophilic channels. ${ }^{16}$ As a result of these two linked dependencies, the reactant permeability of cation contaminated membranes is less than the value for a proton form membrane, ${ }^{17}$ which may have affected the measured potentials as well.

Through plane cation contamination effect can also be visualized from high frequency resistance (HFR) changes. Kienitz et al found more than 200\% increase in HFR for a contaminated membrane which was contaminated by soaking into the contaminant solution. ${ }^{18}$ In our experiment, as contaminant was injected into the air stream, it was expected that HFR would increase on the cathode side. Within 21 hours of contamination, HFR increased in all layers of membrane (Fig. 4.9). Between E3 and E4, 
$50 \%$ increase in HFR was observed. HFR increase between E2 and E3 was 17.6\%, and $6.7 \%$ between E2 and E3. Although E3 was found broken after disassembly, HFR data related to E3 was considered, since E3 was found broken at the end of the wire which was used for voltage measurement, but the other end of the wire was intact which was used for HFR measurement (Fig. 4.7). It should also be mentioned that HFR measurements are not necessarily corresponding to the ohmic loss due to proton transport because all charged ions are excited by AC perturbation during EIS measurements. ${ }^{18}$

\subsection{Summary and Conclusions}

Effect of cationic contamination in PEFCs in the through plane was investigated using a multilayered membrane cell. The MEA was prepared using five layers of

membrane, and four $\mathrm{Pt}$ wires were inserted between the membrane layers. $\mathrm{Ca}^{2+}$ (at a concentration corresponding to $5 \mathrm{ppm}$ ) was injected into the air stream of the fuel cell. Pt electrodes were used to monitor through plane potential due to permeation of hydrogen and oxygen from the anode and the cathode, respectively, and the resistance distribution across the membrane thickness.

At the beginning of the test, the electrode closest to the cathode showed the same potential as the cell potential and other electrodes showed zero potential, as the potential of the electrode closest to the cathode was dominated by oxygen permeation from the cathode, while for the other electrodes, oxygen permeation from the cathode was negligibly small so the potential was dominated by hydrogen reduction reaction. After 32 hours, there was enough oxygen permeation from cathode to other layers of membrane symbolizing the membrane degradation, as oxygen permeation increased with time. 
The aluminum alloy flow field was found to be corroded, as the aluminum originated due to corrosion (possibly nickel from the base layer as well) degraded the cell performance from the beginning of the test. When $\mathrm{Ca}^{2+}$ was injected with air, the cell performance degraded rapidly. Salt was deposited on the GDE and on the flow field surface causing mass transport losses. HFR was increased due to contamination, and in the membrane layer close to the cathode, HFR increase was more than $50 \%$. 


\subsection{References}

1. T. Okada, in Handbook of Fuel Cells-Fundamentals, Technology and Applications., W. Vielstich, H. A. Gasteiger, A. Lamm and H. Yokokawa. Editors, John Wiley \& Sons, Ltd (2010).

2. J. Qi, X. Wang, U. Pasaogullari, L. Bonville and T. Molter, J. Electrochem. Soc., 160, F916 (2013).

3. M. A. Uddin, and U. Pasaogullari, J. Electrochem. Soc., 161, F1081 (2014).

4. B. Kienitz, H. Baskaran and T. Zawodzinski Jr, Electrochim. Acta., 54, 1671 (2009).

5. J. Qi, X. Wang, O. Ozdemir, A. Uddin, U. Pasaogullari, L. J. Bonville, and T. Molter, J. Power Sources, 286, 18 (2015).

6. X. Wang, J. Qi, O. Ozdemir, A. Uddin, U. Pasaogullari, L. Bonville, and T. Molter, J. Electrochem. Soc., 161, F1006 (2014).

7. M. A. Uddin, X. Wang, M. O. Ozdemir, J. Qi, L. Bonville, U. Pasaogullari and T. Molter, ECS Trans., 61(12), 49 (2014).

8. M. A. Uddin, X. Wang, J. Qi, M. O. Ozdemir, L. Bonville, U. Pasaogullari and T. Molter, J. Electrochem. Soc. 162, F373 (2015).

9. M. Watanabe, H. Igarashi, H. Uchida and F. Hirasawa, J. Electroanal. Chem., 399, 239 (1995).

10. M. Watanabe, H. Uchida and M. Emori, J. Electrochem. Soc., 145, 1137 (1998).

11. M. Watanabe, H. Uchida and M. Emori, J. Phy. Chem. B, 102, 3129 (1998).

12. S. Takaichi, H. Uchida and M. Watanabe, Electrochem. Commun., 9, 1975 (2007).

13. S. Takaichi, H. Uchida and M. Watanabe, J. Electrochem. Soc., 154, B1373 (2007).

14. A. Woodman, K. Jayne, E. Anderson, and M. C. Kimble, American Electroplaters and Surface Finishers Society, AESF SUR/FIN '99 Proceedings, 6/21-24, (1999).

15. M. G. Fontana and N. D. Greene, Corrosion Engineering, p. 31, McGraw Hill, New York (1978).

16. K. Broka, P. Ekdunge, J. Appl. Electrochem., 27, 117 (1997).

17. T. Okada, Y. Ayato, H. Satou, M. Yuasa and I. Sekine, J. Phy. Chem. B, 105, 6980 (2001).

18. B. Kienitz, B. Pivovar, T. Zawodzinski, F. H. Garzon, J. Electrochem. Soc. 158, B1175 (2011). 


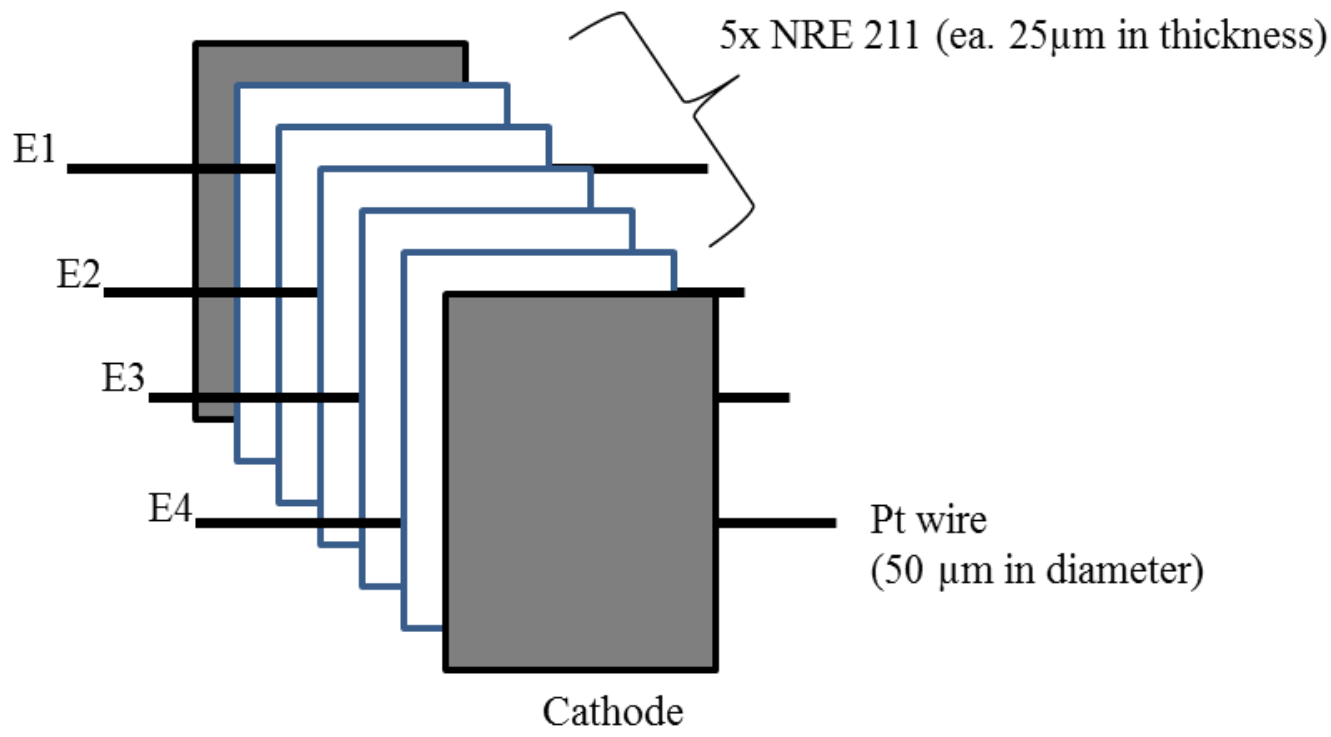

Fig. 4.1. Simple schematic diagram of membrane electrode assembly (MEA). Four Pt wire $(50 \mu \mathrm{m}$ in diameter) electrodes (E1, E2, E3, and E4) were inserted between five layers of Nafion membrane (ea. $25 \mu \mathrm{m}$ in thickness). 


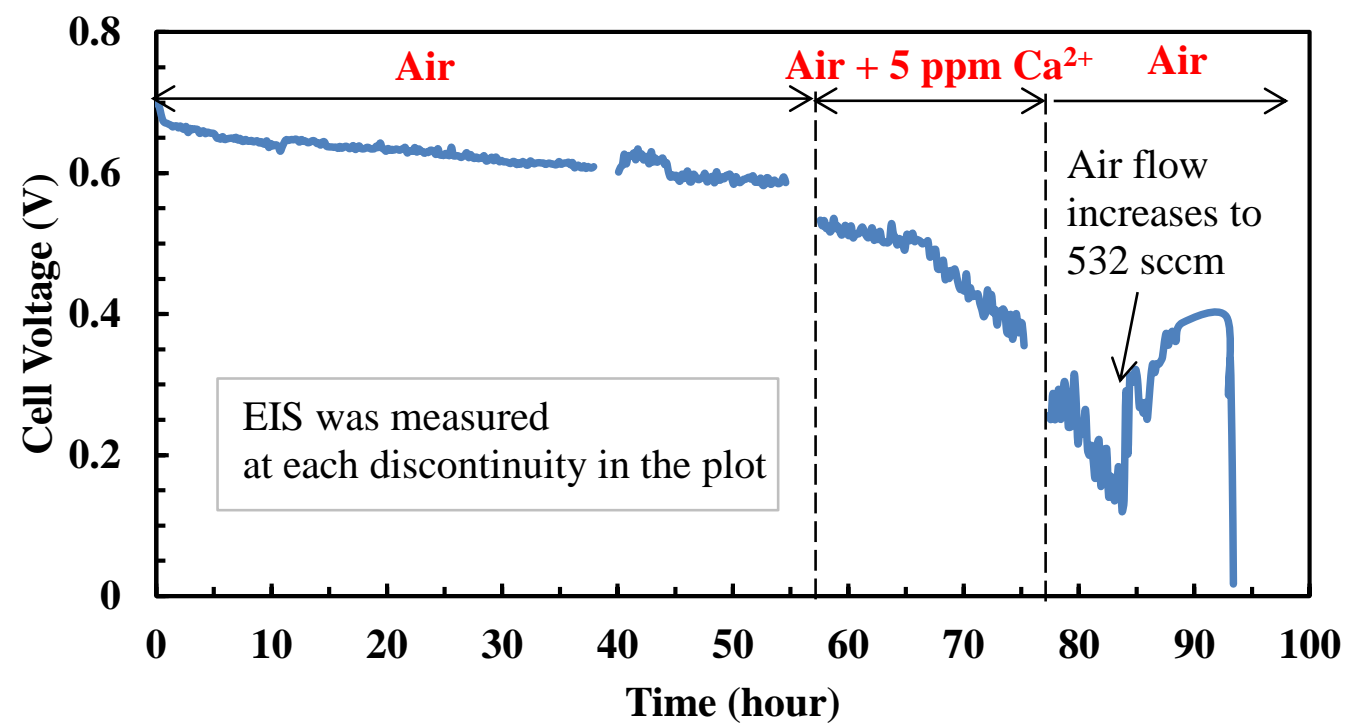

Fig. 4.2. Cell performance measured at $200 \mathrm{~mA} / \mathrm{cm}^{2}$. Operating conditions: cell temperature: $80^{\circ} \mathrm{C}$; flow rate $\mathrm{H}_{2}$ / air: $348 / 332 \mathrm{sccm}$; $\mathrm{A} / \mathrm{C}$ : $50 / 20$ stoic, $25 / 125 \% \mathrm{RH}, 0 / 0$ psig back pressure. 

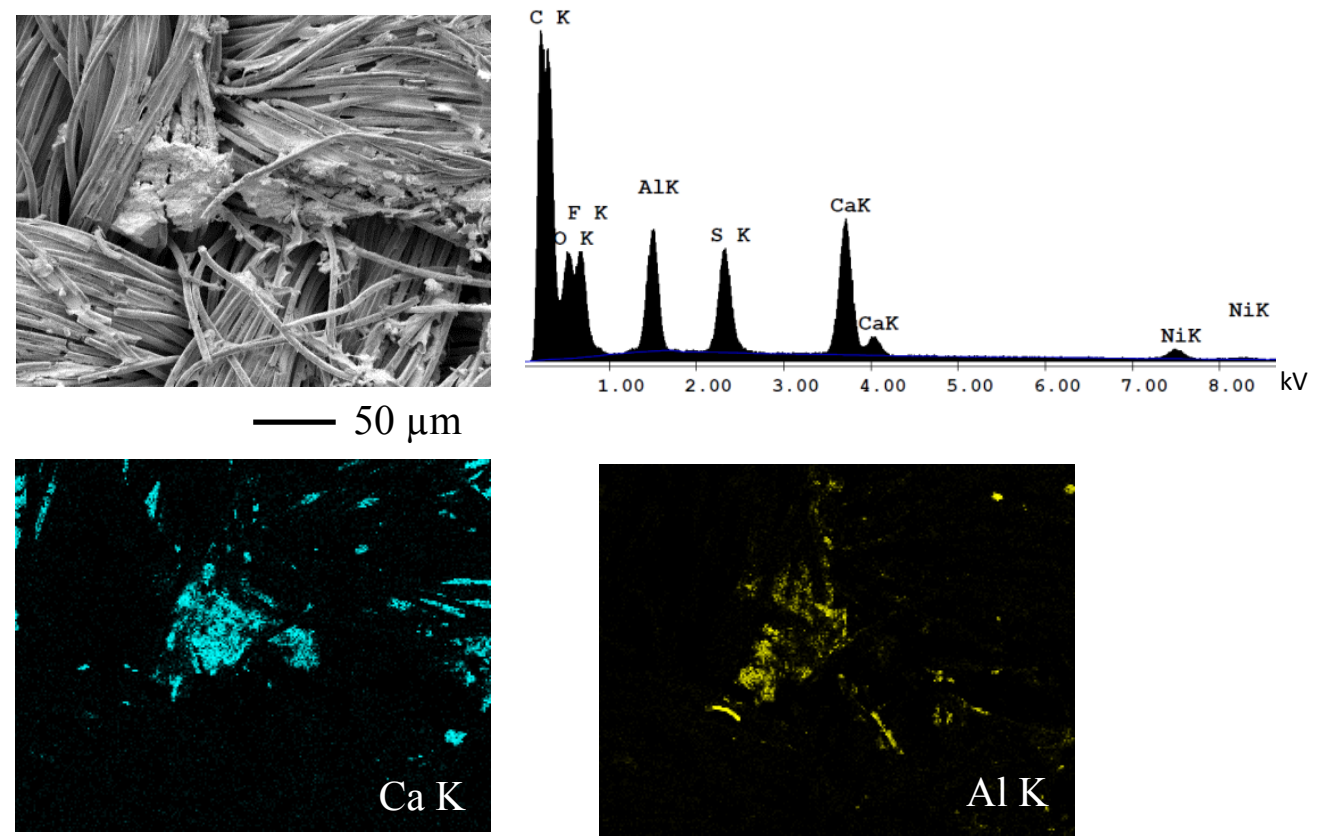

Fig. 4.3. Secondary electron image of cathode GDE surface with elemental spectrum of whole image and elemental mapping of $\mathrm{Ca}$ and $\mathrm{Al}$. 

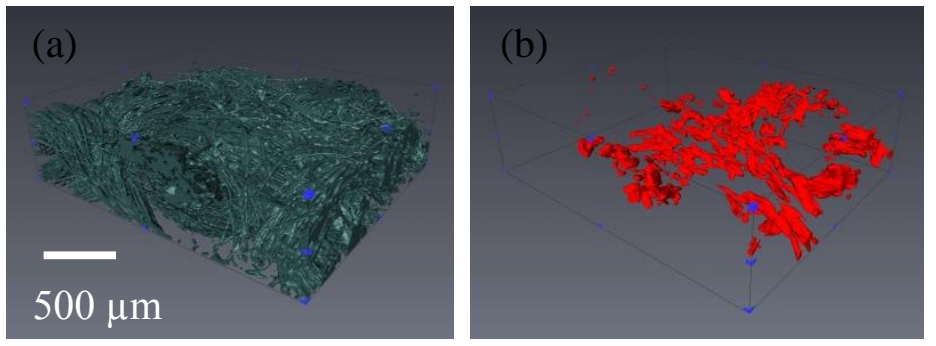

Fig. 4.4. (a) 3D representation of cathode GDE and (b) salt deposit only. 


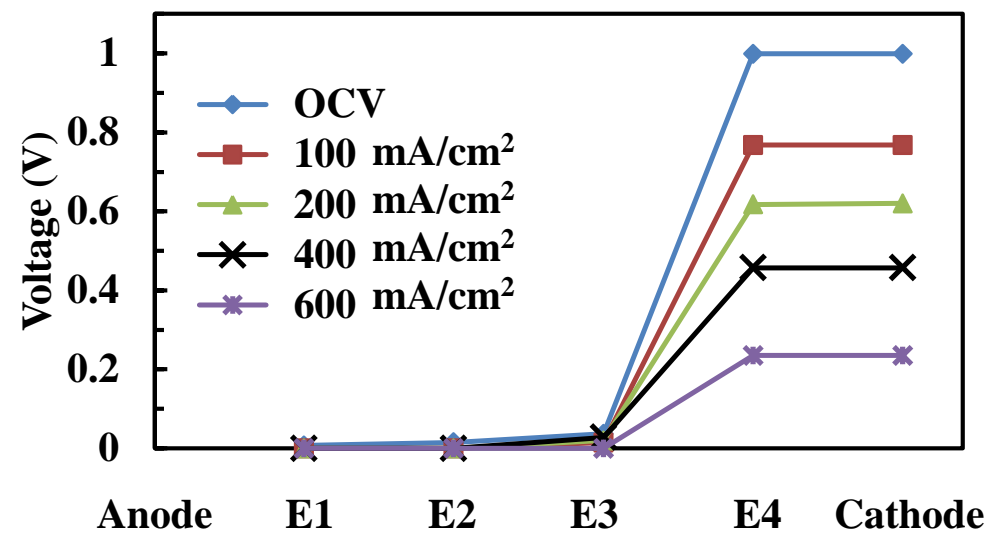

Fig. 4.5. Distribution profile of mixed potential along membrane thickness at BoT. Operating conditions: cell temperature: $80^{\circ} \mathrm{C}$; flow rate $\mathrm{H}_{2} /$ air: $348 / 332 \mathrm{sccm}$; A/C: 50/20 stoic, 25/125\% RH, 0/0 psig back pressure. 


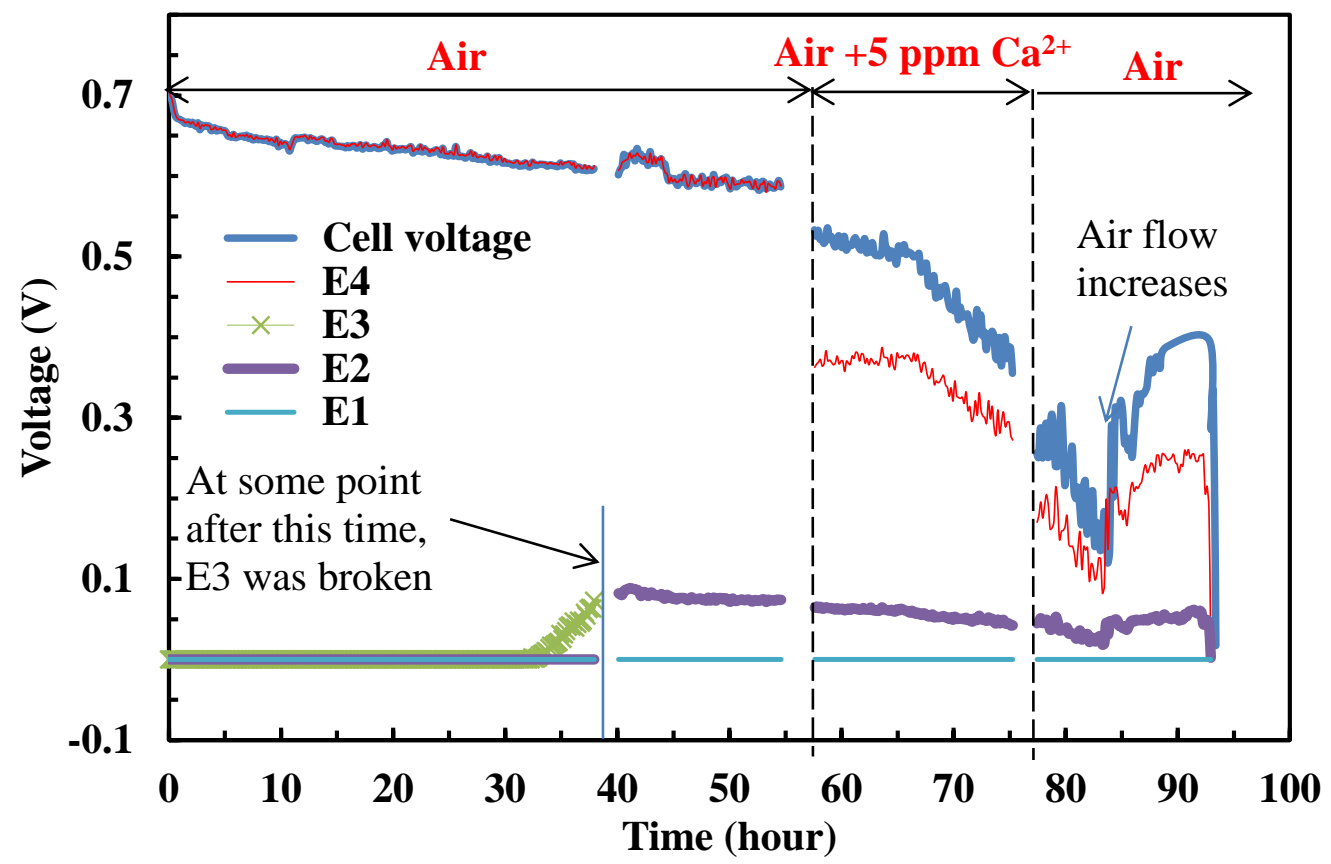

Fig. 4.6. Through plane voltage change with time when cell was exposed to $\mathrm{CaSO}_{4}$ at $200 \mathrm{~mA} / \mathrm{cm}^{2}$. At each discontinuity in the plot, EIS was measured. Operating conditions: cell temperature: $80^{\circ} \mathrm{C}$; flow rate $\mathrm{H}_{2} /$ air: $348 / 332 \mathrm{sccm}$; A/C: 50/20 stoic, $25 / 125 \% \mathrm{RH}$, 0/0 psig back pressure. 


\begin{tabular}{l}
\hline EIS was \\
measured \\
from this end
\end{tabular}

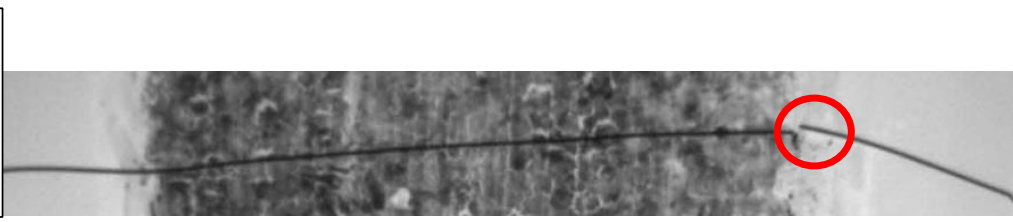

Voltage was

measured

from this end

Fig. 4.7. Broken position of Electrode 3 (E3) (shown in circle). 


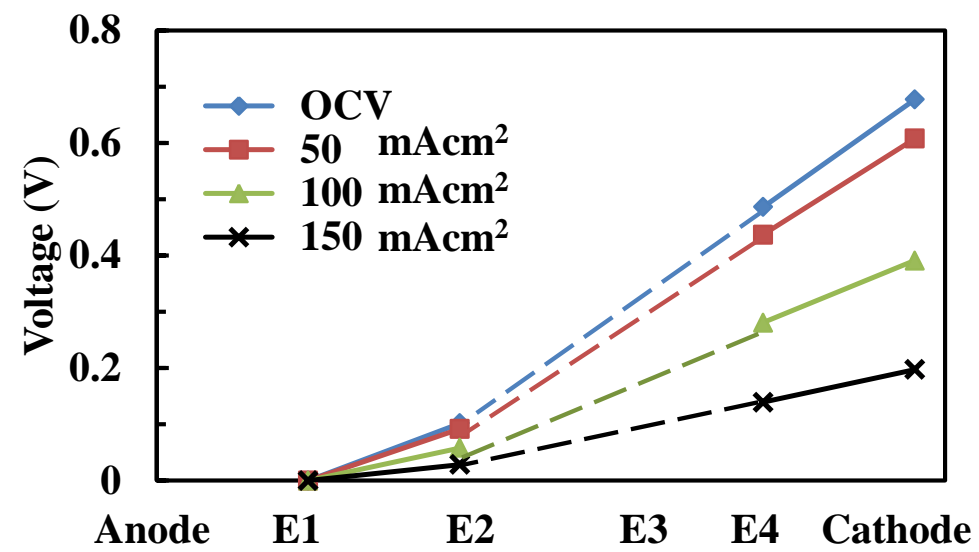

Fig. 4.8. Distribution profile of mixed potential along membrane thickness at EoT. After disassembly, E3 was found discontinuous. So, potentials for E3 were not shown here. Operating conditions: cell temperature: $80^{\circ} \mathrm{C}$; flow rate $\mathrm{H}_{2} /$ air: $348 / 332 \mathrm{sccm}$; A/C: 50/20 stoic, 25/125\% RH, 0/0 psig back pressure. 


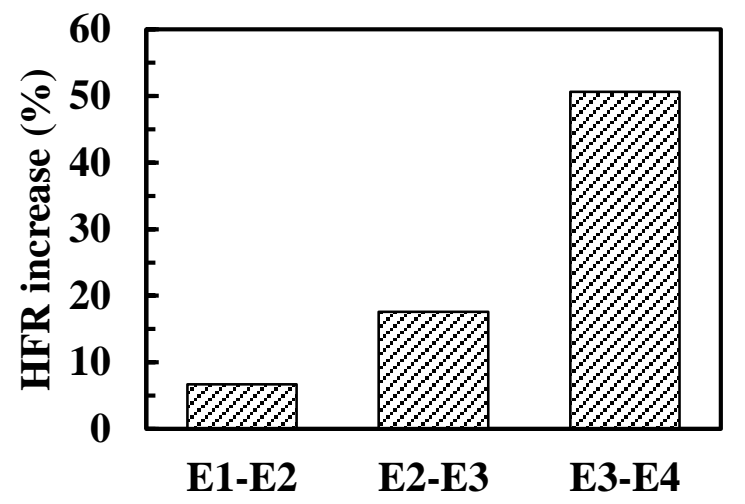

Fig. 4.9. High frequency resistance (HFR) increase (\%) between electrodes within 20 hours of contamination. Operating conditions: current density: $200 \mathrm{~mA} / \mathrm{cm}^{2}$; cell temperature: $80^{\circ} \mathrm{C}$; flow rate $\mathrm{H}_{2} /$ air: $348 / 332 \mathrm{sccm}$; $\mathrm{A} / \mathrm{C}$ : 50/20 stoic, $25 / 125 \% \mathrm{RH}, 0 / 0$ psig back pressure. 


\section{DISTRIBUTED EFFECTS OF CALCIUM ION \\ CONTAMINANT ON POLYMER ELECTROLYTE}

\section{FUEL CELL PERFORMANCE}

\subsection{Introduction}

As shown in chapter 2 and chapter 4 , we observed a cationic contamination mechanism that was not previously mentioned in open literature. Cationic salts were deposited on both the flow field and the GDL surface causing serious mass transport loss. It was also confirmed in our previous studies. ${ }^{1,2}$ In our operating conditions, salt depositions was found mostly in the downstream of the cell, ${ }^{1}$ indicating a need for study the spatial performance change due to cation contamination.

There are many studies available on local performance distribution due to the influence of various parameters: flow field geometry, clamping pressure, operating conditions, types of membranes and GDL, and carbon monoxide (CO) poisoning. ${ }^{3}$ To our knowledge, there is no such study related to cation contamination. This chapter presents the effect of the cation contamination on spatial performance distribution under galvanostatic and potentiostatic load control of a segmented cell.

\subsection{Experimental}

The details of the experimental setup and procedures were described in our previous studie ${ }^{1}$ where we used a conventional, single cell hardware. In this study, instead of the single cell hardware, a segmented cell hardware was used to observe spatial 
performance distribution. The segmented cell hardware consisted of an aluminum alloy (T6061-T6) anode flow field, a segmented cathode flow field, two gold-plated aluminum alloy end plates and one copper current collector. The cathode flow field was divided into eight segments. Eight pieces of equal size aluminum alloy current collectors were placed inside a PTFE block and continuous straight flow channels were machined through both the PTFE and the aluminum segments (Fig. 5.1). Both flow fields consisted of 5 straight flow channels with $1.0 \mathrm{~mm}$ width, $1.0 \mathrm{~mm}$ channel depth and $1.0 \mathrm{~mm}$ landing. To prevent corrosion and contamination, all the aluminum alloy parts were gold plated. Moreover, to prevent contamination from the end plates, a Teflon tube was used as a liner for the gas ports, passing through end plate into the flow field. To measure local performance distribution, $100 \mathrm{~m} \Omega$ shunt resistors were attached to each segment as shown in Fig. 5.1. The total active area of the cell was $5 \mathrm{~cm}^{2}$. The MEA was prepared with a catalyst coated membrane $(\mathrm{CCM})$ which was Gore ${ }^{\circledR}$ PRIMEA $^{\circledR}$ Membrane Electrode Assemblies (GORE, PRIMEA and design are trademarks of W. L. Gore and Associates Inc., Elkton, MD, USA) and two Freudenberg C2 (Freudenberg FCCT SE \& Co. KG, Germany) gas diffusion layers. Pt loading for the cathode and anode catalyst layers was 0.4 and $0.1 \mathrm{mg} / \mathrm{cm}^{2}$, respectively.

In our previous study, ${ }^{1}$ we tested the cell galvanostatically with various concentration of $\mathrm{CaSO}_{4}(1.14 \mathrm{mM}, 2.85 \mathrm{mM}$, and $5.7 \mathrm{mM})$. It was observed that high concentrations $(2.85 \mathrm{mM}$ and $5.7 \mathrm{mM})$ of $\mathrm{CaSO}_{4}$ resulted in significant performance loss and caused salt precipitation which caused mass transport loss. Low current density $\left(200 \mathrm{~mA} / \mathrm{cm}^{2}\right)$ operation caused more salt precipitation, which clogged gas channels and blocked the transport of reactants. In this study, $2.85 \mathrm{mM}$ of $\mathrm{CaSO}_{4}$ was selected to 
observe obvious performance degradation. The segmented cell was operated in two modes: galvanostatically and potentiostatically. A high air flow was maintained at the cathode to carry more water in the cathode that can help to prevent contaminant precipitation and a high hydrogen flow at the anode to limit the anode polarization overpotential and to make sure that performance degradation during the tests can be attributed to the contamination. All the operating conditions were listed in Table 5.1.

Similar to the previous studies, ${ }^{1-2}$ the cell was tested in Teledyne test station (Teledyne MEDUSA RD, TELEDYNE Energy Systems, Inc., MA, USA) interfaced with a Scribner 890C load box (Scribner Associates Inc. NC, USA). For injecting contaminant solution a micro flow nebulizer (ES-2005, PFA-400, Elemental Scientific, Inc., NE, USA) was used with a high performance liquid chromatography (HPLC) pump (Series III Pump, Scientific Systems Inc., PA, USA). In each test, the cell was conditioned using a constant voltage $(0.6 \mathrm{~V})$ break-in procedure and the cell was run with pure air for 24 hours. Then the contaminant was injected into the air stream for 96 hours. Finally, pure air was used for another 24 hours.

After the test, the cell was disassembled and the MEA was characterized by SEM/EDX (FEI ESEM Quanta 250, Hillsboro, OR, USA) analysis.

\subsection{Results and discussion}

Fig. 5.2 shows the polarization curves for all the segments at the beginning of the test. The segments upstream (close to the gas inlet) of the cell median have higher performance compared to the segments downstream (close to the gas outlet) of the cell, as a result the current density is not uniform throughout the cell. To minimize nonuniformity issue due to the reactants, very high stoichiometry of the reactants was used 
during contamination test. Other causes for the non-uniformity include non-uniform operating conditions (e.g. temperature), flow field design, non-uniform assembly pressure and microstructure of the gas diffusion electrode (thickness, structure, ionic and electronic conductivity, gas diffusion layer). ${ }^{4}$

Fig. 5.3 shows the average cell voltage and normalized current density distribution profile for each segment of the cell tested in galvanostatic mode at a constant overall cell current of $200 \mathrm{~mA} / \mathrm{cm}^{2}$. The current density was normalized dividing by the average current density of last five hours (19h to $24 \mathrm{~h}$ ) of the baseline to facilitate easier comparison of all the segments. There was no change in the trend of curves due to this normalization.

During the baseline test of 24 hours, pure air was injected through the cathode. The voltage and the current density remained constant in all segments. Following the baseline test, the contaminant was injected in the air stream. After contaminant injection, the voltage in each segment started to decrease, and after 50 hours, voltages started to fluctuate. The voltage fluctuation was found to be mainly due to the mass transport loss. Similar to the previous study (9), significant salt precipitation was observed (Fig. 5.4). As these deposits accumulate with time, they form a barrier for oxygen transport to the catalyst layer and act as a barrier for the water removal from the cell. Additionally, these deposits migrate into the GDL, and they may also affect the GDL wet proofing allowing water to accumulate locally. This water is free to move within the cell, and we believe that it has moved from cell inlet to the exit with the reactant flow. So when water accumulates in the cell, the voltage decreases and when water is removed voltage increased back. 
From the current density profile in Fig. 5.3b, it was observed that the upstream segments were first affected by the contaminant, and the current density in the upstream segments decreased, while the downstream segments increased, although at the beginning of the test, in uncontaminated conditions, upstream segments have higher performance compared to downstream segments (shown in Fig. 5.2) which is typical in segmented cells. Since it was a constant current test, when the current in the segments closest to the gas inlet decreases, the current for the other segments must increase to maintain a constant total current. Segment 0 which was close to the gas inlet was first affected by the contaminant and the current density decreased and remained lower throughout the test. The other segments picked up that current, although all other segments were also contaminated later, and there was a sequence in current density distribution from the gas inlet to the gas outlet: segment $0<$ segment $1<\ldots<$ segment 7 . So, from the galvanostatic test, it is certain that upstream portion of the cell is first affected by the contaminants, but it is not possible to make a decision about the downstream of the cell.

When the cell was disassembled after the test, salt deposit was found distributed over the entire flow field and the GDL surface (Fig. 5.4). So the entire active area was affected by the contaminants, but this was not clear from the distributed current density profile.

To get a clearer idea about the performance distribution, a new cell was assembled as described earlier and tested in potentiostatic mode with lower contaminant concentration in the air stream. Fig. 5.5 shows the average cell voltage, average cell resistance, and normalized current density distribution profile for each segment of the cell tested in potentiostatic mode. The cell was tested at a constant voltage $(0.6 \mathrm{~V})$, and the 
cell resistance was measured by current interrupt, which includes the bulk membrane resistance, the GDL electronic resistance, and the contact resistance between fuel cell components. Since it was a galvanostatic test, there was no control on local current distribution. It was observed that all segments were affected by the contaminant, and current density in all segments decreased with time. The performance of the downstream segments was lower than the upstream segments which were completely opposite to the galvanostatically tested cell. It can be explained by our previous study ${ }^{1}$ where it was reported that although $\mathrm{Ca}^{2+}$ was injected in the super saturated $(125 \% \mathrm{RH})$ air stream, outlet of the cell became dry in our operating conditions causing more salt precipitation at the outlet of the cell. As a result, the performances of the downstream segments were lower than the upstream segments. At the end of 96 hour of test, the cell can no longer sustain any load, and even removing the contaminant injection did not recover the cell performance and the cell could no longer hold constant voltage. The cell voltage fluctuated similar to the potentiostatic test which can be attributed to the salt deposition inside the cell similar to the Fig. 5.4.

The cell resistance (as shown in Fig. 5.5a) did not get affected much by the contamination up to 80 hours and then it started to increase. During first 24 hour baseline, resistance increase rate was $0.3 \mathrm{~m} \Omega . \mathrm{cm}^{2} / \mathrm{h}$, from $24 \mathrm{~h}$ to $80 \mathrm{~h}$ resistance increase rate was $0.8 \mathrm{~m} \Omega . \mathrm{cm}^{2} / \mathrm{h}$ and after $80 \mathrm{~h}$, resistance increase rate was $26.6 \mathrm{~m} \Omega . \mathrm{cm}^{2} / \mathrm{h}$. We believe, the sharp resistance increase was mostly due to salt deposition inside the cell that hindered the reactant transport in and out of the cell. 
Postmortem analysis of both the cells was carried out with SEM/EDX. There was no significant difference between both the cells; hence the analysis for the cell tested in galvanostatic mode is presented.

Fig. 5.6 shows the SEM image of the cathode GDL surface. It shows a significant amount of salt deposit on GDL surface, which caused mass transport loss and voltage fluctuations. EDX results and elemental map show that salt contains calcium, sulfur, and oxygen. It also contains aluminum. During the test, $\mathrm{CaSO}_{4}$ solution was injected, so it is reasonable to detect calcium and sulfur. In case of aluminum, we suspect that it came from the sub-surface of gold coated aluminum alloy flow field. After the test, inspection showed that some of the gold layer had lifted off of the flow field and there was some evidence of micro-cracks in the gold coating on aluminum flow field which were enough to allow the corrosion of aluminum. ${ }^{\mathbf{5}}$ Moreover, on the gold plated aluminum flow field, two dissimilar materials ( $\mathrm{Al}$ and $\mathrm{Au}$ ) with a galvanic potential difference ${ }^{6}$ were in contact with the presence of calcium sulfate as the electrolyte which would allow a microgalvanic cell on the surface of the flow field and galvanic corrosion.

Fig. 5.7 shows MEA cross section and elemental mapping of S and Ca. The SEM image of a portion of the cathode GDL is also shown, indicating the salt deposit inside the GDL. The elemental map of Ca clearly demonstrates that $\mathrm{Ca}$ is only detected inside the cathode GDL. Similar to the surface of the GDL, Al is also found inside the GDL. But no $\mathrm{Ca} / \mathrm{Al}$ is detected in the CCM. These results conform to our previous findings, ${ }^{1}$ which shows that highly hydrophobic nature of the microporous layer (MPL) in GDL acts as a barrier to the transport of contaminant solution into the $\mathrm{CCM}^{7}$ 


\subsection{Conclusion}

In this chapter, distributed effects of the cation contamination on PEFC was

studied by introducing $\mathrm{Ca}^{2+}$ solution in the air stream of an operating fuel cell that had segmented cathode flow field. The cell was operated both in galvanostatic and potentiostatic modes. In the galvanostatic test, segments upstream of the cell median were first affected by the contaminant and their current decreased. The segments downstream of the cell median demonstrated an increase in current, although salt deposit was observed throughout cathode flow field and GDL surface. In the constant total current test, when the cell current in the upstream segments decreased, downstream segments increased their current to maintain the constant total current. During contamination, the cell voltage decreased and fluctuated as a result of salt deposits on both the cathode flow field and the surface of the GDL, which caused mass transport losses.

In the potentiostatic test, all the segments were affected by the contaminants and the current density of all segments decreased with times. It was also observed that the segments downstream of the cell demonstrated lower performance than the segments upstream of the cell which conforms to our previous findings.

In this chapter, all the results were based on $\mathrm{Ca}^{2+}$ contamination as an air impurity in PEFC. For other cations which may be introduced to the cell through air/fuel stream or balance of plant components, the quantitative results may change, but change in observed trends is unlikely. 


\subsection{References}

1. X. Wang, J. Qi, O. Ozdemir, A. Uddin, U. Pasaogullari, L.J. Bonville, T. Molter, J. Electrochem. Soc., 161, F1006 (2014).

2. J. Qi, X. Wang, O. Ozdemir, M.A. Uddin, L.J. Bonville, U. Pasaogullari, T. Molter, J. Power Sources, 286, 18 (2015).

3. L.C. Pérez, L. Brandão, J.M. Sousa, A. Mendes, Renew. Sustain. Energy Rev.15, 169 (2011).

4. Z. Liu, Z. Mao, B. Wu, L. Wang, V.M. Schmidt, J. Power Sources, 141, 205 (2005).

5. A. Woodman, K. Jayne, E. Anderson, and M. C. Kimble, American Electroplaters and Surface Finishers Society, AESF SUR/FIN '99 Proceedings, 6/21-24, (1999).

6. M. G. Fontana and N. D. Greene, Corrosion Engineering, p. 31, McGraw Hill, New York (1978).

7. M.A. Uddin, J. Park, X. Wang, J. Qi, L. Bonville, U. Pasaogullari, T. Molter, ECS Trans. 64(3), 537 (2014). 
Table 5.1. Contaminant and operating conditions.

\begin{tabular}{|c|c|c|c|c|c|c|c|}
\hline $\begin{array}{c}\text { Operation } \\
\text { mode }\end{array}$ & Contaminant & $\begin{array}{c}\text { Concentration } \\
\text { (mM) }\end{array}$ & $\begin{array}{c}\text { Concentration } \\
\text { in dry air } \\
\text { (ppm) }\end{array}$ & $\begin{array}{c}\mathrm{RH} \\
(\mathrm{A} / \mathrm{C}) \\
(\% / \%)\end{array}$ & $\begin{array}{c}\text { BP } \\
(\mathrm{A} / \mathrm{C}) \\
(\mathrm{kPag})\end{array}$ & $\begin{array}{l}\mathrm{H}_{2} / \text { Air flow } \\
\text { rate (slpm) }\end{array}$ & $\begin{array}{l}\text { Nebulizer } \\
\text { flow rate } \\
(\mu \mathrm{L} / \mathrm{min})\end{array}$ \\
\hline $\begin{array}{l}\text { Galvanostatic } \\
\left(200 \mathrm{~mA} / \mathrm{cm}^{2}\right)\end{array}$ & $\mathrm{CaSO}_{4}$ & 2.85 & 21 & $100 / 125$ & $10 / 100$ & $0.35 / 0.33$ & 110 \\
\hline $\begin{array}{l}\text { Potentiostatic } \\
\qquad(0.6 \mathrm{~V})\end{array}$ & $\mathrm{CaSO}_{4}$ & 2.85 & 5 & $25 / 125$ & $10 / 100$ & $1.75 / 1.66$ & 130 \\
\hline
\end{tabular}




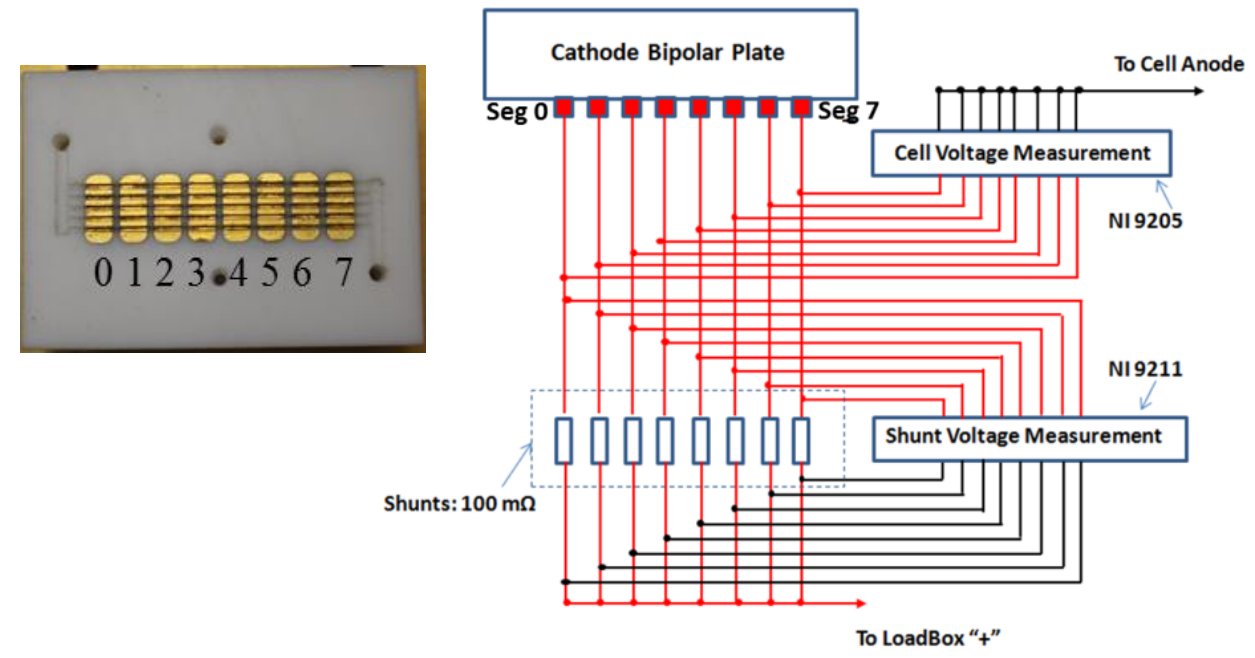

Fig. 5.1. Segmented cathode flow field and schematic diagram of data acquisition system. Numbers (0-7) denote the segment number from gas inlet to outlet of the cell. 


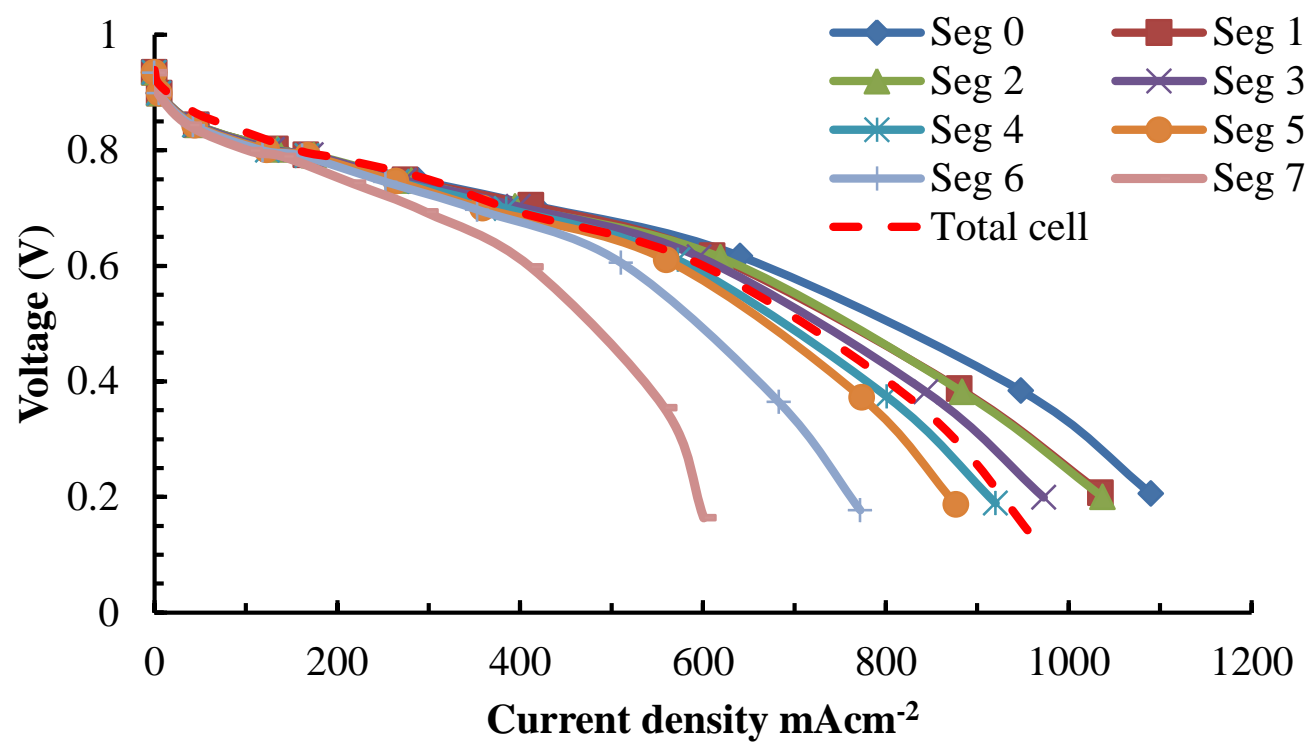

Fig. 5.2. Polarization curves for each segment at the beginning of the test (BoT). Operating conditions: cell temperature: $80^{\circ} \mathrm{C}$; minimum flow rate $50 \mathrm{sccm}$; Anode/Cathode: 2/2 stoic; 100/75\% RH; 0/0 kPag back pressure. 


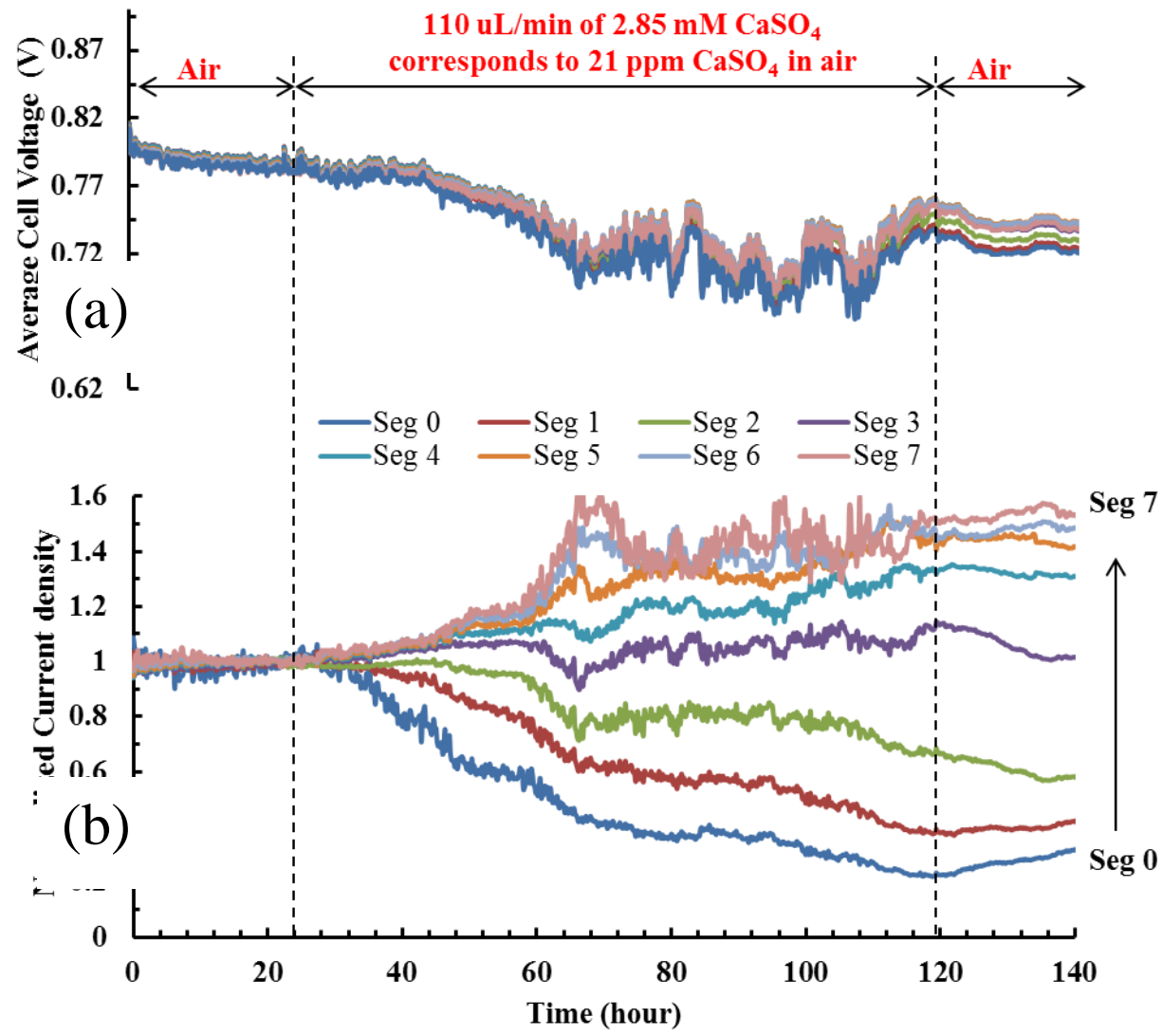

Fig. 5.3. (a) Cell voltage and (b) current density distribution profile of each segment of the cell tested in galvanostatic mode (at $200 \mathrm{~mA} / \mathrm{cm}^{2}$ ). Operating conditions: cell temperature: $80^{\circ} \mathrm{C} ; \mathrm{H}_{2}$ /Air flow rate: 0.35/0.33 slpm; Anode/Cathode: 100/125\% RH; 10/100 kPag back pressure. 

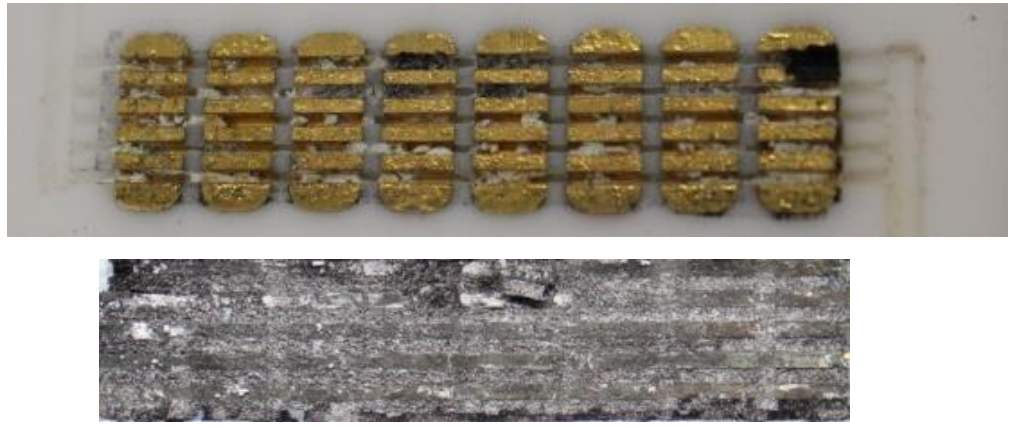

Fig. 5.4. Cathode flow field and GDL surface after the cell tested in galvanostatic mode. 


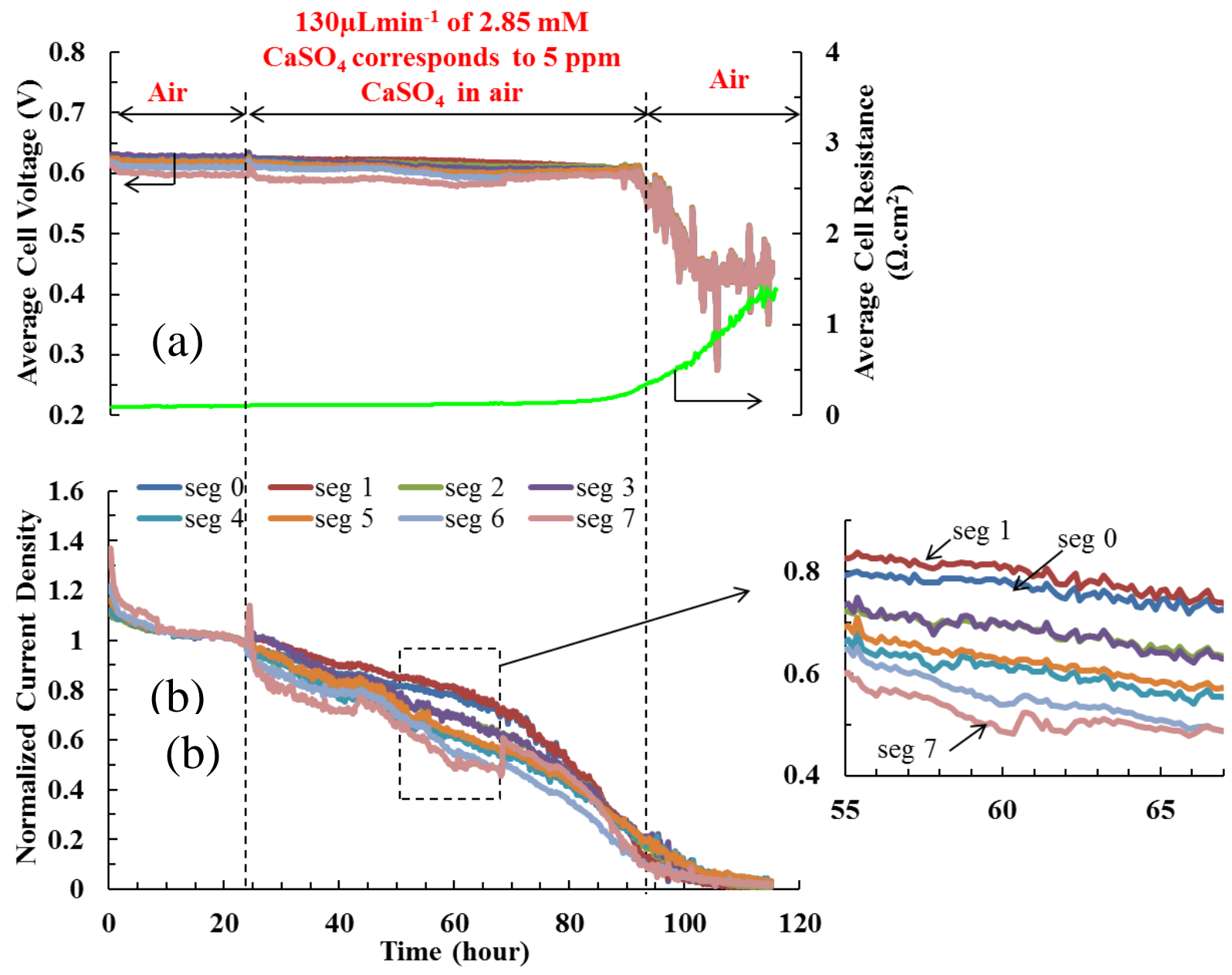

Fig. 5.5. (a) Cell voltage and resistance and (b) current density distribution profile of each segment of the cell tested in potentiostatic mode (at $0.6 \mathrm{~V}$ ). Operating conditions: cell temperature: $80^{\circ} \mathrm{C} ; \mathrm{H}_{2}$ /Air flow rate: 1.75/1.66 slpm; Anode/Cathode: 100/125\% RH; 10/100 kPag back pressure. 

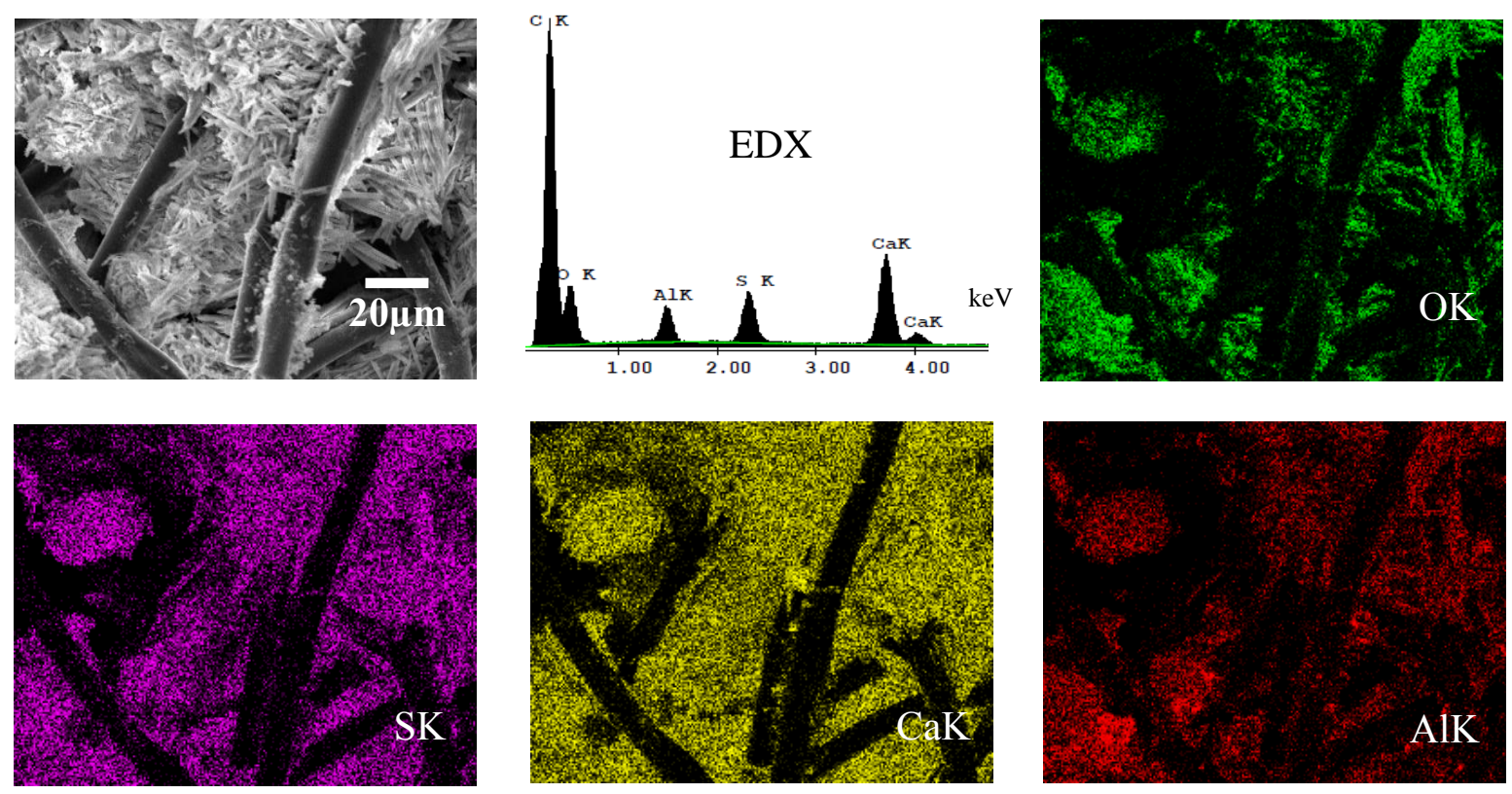

Fig. 5.6. SEM image of cathode GDL surface of the galvanostatic test with elemental spectrum of the whole SEM image and elemental map of $\mathrm{O}, \mathrm{S}, \mathrm{Ca}$, and $\mathrm{Al}$. 


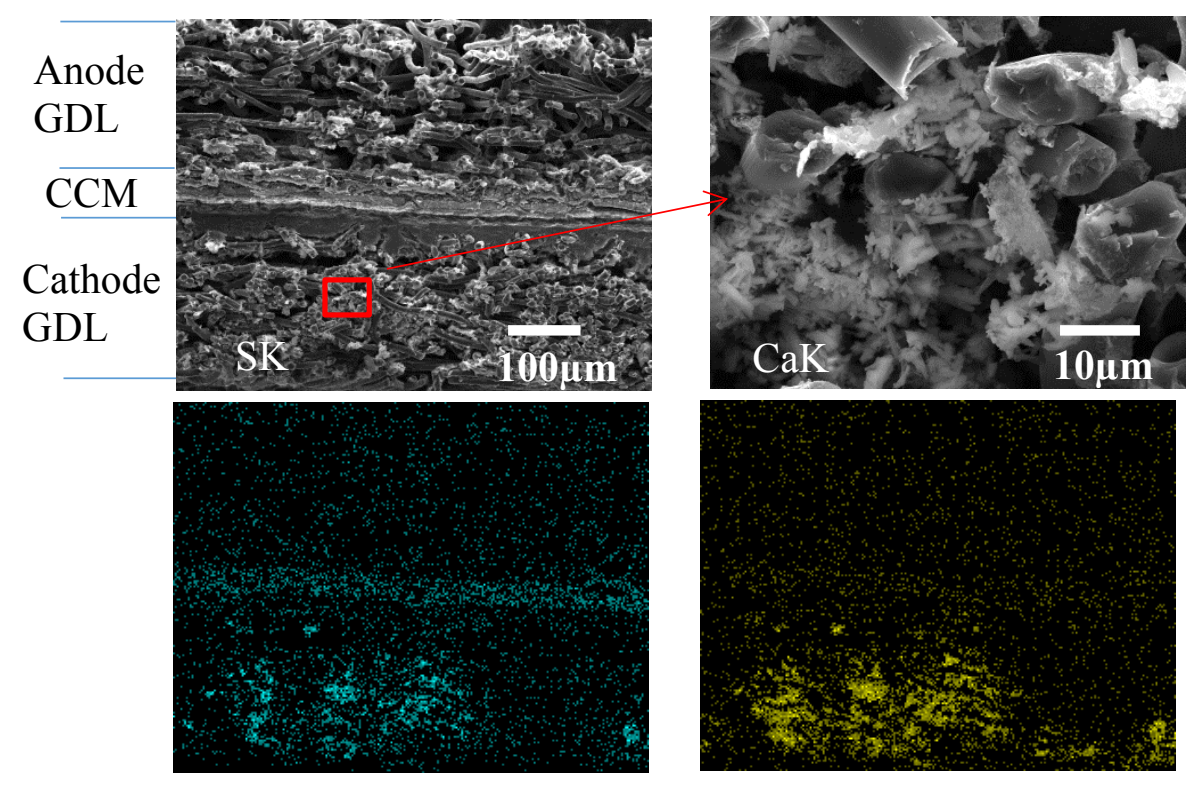

Fig. 5.7. SEM image of MEA cross section after the galvanostatic test with an enlarged view of cathode GDL and elemental map of $\mathrm{S}$ and $\mathrm{Ca}$ of the whole cross section. 


\section{CATHODE CATALYST LAYER THINNING IN \\ POLYMER ELECTROLYTE FUEL CELL: A CATION \\ CONTAMINATION EFFECT}

\subsection{Introduction}

The results presented in chapter 2, 3, 4 and 5 show that the cation solutions not only affects the polymer membrane by reducing the proton transport and water content, it also influences the electrode's water management significantly which result in salt precipitation on the flow field and the gas diffusion layer (GDL) surface that causes serious mass transport loss. Owing to the hydrophobic nature of GDL and low solubility product of cationic solution, most of the salt is preferentially deposited on the GDL and flow channels rather than penetrating through the GDL and the electrode layers to contaminate the polymer membrane. So there is need for study the effect of cation in membrane and catalyst layer. To ensure cations are present in the membrane electrode assembly (MEA), the catalyst coated membrane (CCM) needs to be contaminated by soaking in a cationic solution before the cell is assembled.

To understand the impact and mechanism of cation contamination in PEFC, several tests were conducted with ex-situ contamination of the polymer membrane with various cations. Okada and co-workers extensively investigated the effect of various metal cations $\left(\mathrm{Li}^{+}, \mathrm{Na}^{+}, \mathrm{Ca}^{2+}, \mathrm{Fe}^{2+}, \mathrm{Ni}^{2+}, \mathrm{Cu}^{2+}, \mathrm{Rb}^{2+}, \mathrm{Cs}^{+}\right)$on the oxygen reduction reaction (ORR) kinetics, thermodynamics, and transport properties of perfluorosulfonic acid (PFSA) membranes. ${ }^{1-8}$ They reported that with the exception of $\mathrm{Li}^{+}$, all foreign 
cations have higher affinity towards the sulfonic acid side chain of the PFSA ionomer than proton and the multivalent cations show higher affinity for sulfonic acid groups than the mono-valent cations. Once the cations enter the ionomer, they replace protons resulting in reduced ionic conductivity and water content, as well as lowering gas

permeability through the ionomer. ${ }^{1-8}$ Later, other researchers confirmed the findings of Okada group. ${ }^{9-12}$

In this chapter, we show that cations can also cause thinning of the cathode catalyst layer. In order to analyze the effect of $\mathrm{Ca}^{2+}$ ion on catalyst layer and membrane, the CCM is pre-soaked in $\mathrm{CaSO}_{4}$ solution and tested in fuel cell mode for 400 hours. An as received CCM (without contamination) was also tested in same condition for comparison.

\subsection{Experimental}

\subsubsection{Materials}

The CCMs are GORE® PRIMEA® Membrane Electrode Assemblies (GORE, PRIMEA and design are trademarks of W. L. Gore and Associates) with a Pt loading of $0.4 \mathrm{mg} / \mathrm{cm}^{2}$ for both anode and cathode, and the gas diffusion layers are Freudenberg C4 (Freudenberg FCCT SE \& Co. KG, Germany). Calcium sulfate (99.99\% pure, SigmaAldrich ${ }^{\circledR}$, St. Louis, MO, USA) is used as the contaminant. Ultra-high purity hydrogen (99.999\%, Airgas Inc., Hastings, NE) and zero grade air (99.8\%, Airgas Inc., Hastings, NE, USA) are used in fuel cell testing. 


\subsubsection{CCM Contamination Procedure}

The details of the contamination procedure are described in elsewhere.$^{10}$ In brief, the cationic solution is prepared with $0.9 \mathrm{mM}$ of CaSO 4 and $29.1 \mathrm{mM}$ of $\mathrm{H}_{2} \mathrm{SO}_{4}$. To be consistent with our previous studies, the total sulfate concentration was maintained as 30 $\mathrm{mM}$. Initially, the CCM is treated with cationic contaminant solution at room temperature for one hour and then the solution with $\mathrm{CCM}$ was heated to $80^{\circ} \mathrm{C}$ and held for $24 \mathrm{~h}$. Subsequently, the contaminated CCM is cooled to room temperature and thoroughly rinsed with ample quantity of DI water.

\subsection{Ion Exchange Capacity measurement}

Ion exchange capacity (IEC) measurement is a titration procedure used to determine the acid capacity of the polymer, and it is defined as milli-equivalent of ion exchange group included in $1 \mathrm{~g}$ dry membrane and can be expressed by the following equation

$$
\text { IEC }=\frac{\text { Mole of } \mathrm{H}^{+}}{\text {Weight of dry membrane }}
$$

A procedure similar to Jing et al. ${ }^{10}$ is utilized to measure IEC of both an asreceived CCM and a contaminated CCM. The CCM coupon with $2.5 \mathrm{~cm} \times 2.5 \mathrm{~cm}$ is rinsed in approximately $50 \mathrm{~mL}$ DI water for at least $30 \mathrm{~min}$. Then the CCM coupon is soaked in $50 \mathrm{~mL}$ of $2 \mathrm{M} \mathrm{NaCl}$ solution for $24 \mathrm{~h}$. The solution is then titrated against $0.01 \mathrm{M} \mathrm{NaOH}$ with phenolphthalein indicator. A blank consisting of $50 \mathrm{~mL}$ of $2 \mathrm{M} \mathrm{NaCl}$ is also titrated and the base volume is subtracted. The result is calculated as an average of three replicates. 


\subsubsection{Fuel Cell Tests}

A fuel cell test stand (Teledyne MEDUSA RD, TELEDYNE Energy Systems, Inc., Hunt Valley, MD, USA) interfaced with a Scribner 890C load box (Scribner Associates Inc. Southern Pines, NC, USA) is employed for the cell test. A set of $25 \mathrm{~cm}^{2}$ single-cell hardware (Fuel Cell Technology, Albuquerque, NM, USA) is used for each test.

Two fuel cells are built, one with an as-received CCM, and the other with the contaminated CCM. After assembly, the cells are conditioned using a constant voltage break-in procedure. The cell voltage is set at $0.6 \mathrm{~V}$ with cell temperature of $80^{\circ} \mathrm{C}, \mathrm{H}_{2} /$ Air stoichiometric flow of $2 / 2$, anode/cathode relative humidity $(\mathrm{RH})$ of $100 \% / 75 \%$, without backpressure, and the cell was run overnight until a stable performance was achieved. After break-in, polarization curves, cyclic voltammetry (CV) for electrochemical surface area, and liner sweep voltammetry (LSV) for hydrogen crossover are measured. The operating conditions for polarization curves are similar to those for conditioning. $\mathrm{H}_{2}$ crossover and CV curves were measured using a potentiostat/galvanostat (Solartron SI 1287). During both $\mathrm{H}_{2}$ crossover and $\mathrm{CV}$ experiments, cathode was purged with $\mathrm{N}_{2}$, while $\mathrm{H}_{2}$ was fed through anode with a flow rate of $250 \mathrm{sccm}$. The cell temperature was set at $80{ }^{\circ} \mathrm{C}$, and $100 \%$ and $75 \%$ relative humidity was maintained at the anode and the cathode, respectively. The crossover curves were recorded at a scan rate of $2 \mathrm{mV} / \mathrm{sec}$ over the range of $0.1-0.4 \mathrm{~V}$. The $\mathrm{CV}$ curves were recorded at a scan rate of $20 \mathrm{mV} / \mathrm{sec}$ over the range of $0.05-0.8 \mathrm{~V}$.

After the beginning of the test (BoT) diagnostics, the cells are tested for 400 hours. As-received CCM is tested in galvanostatic mode at $400 \mathrm{~mA} / \mathrm{cm}^{2}$ with the cell 
temperature $80^{\circ} \mathrm{C}, \mathrm{H}_{2} /$ Air flow rate of $1.66 / 1.75 \mathrm{slpm}$, anode/cathode relative humidity (RH) of $25 \% / 125 \%$ and with a backpressure of $1.5 / 15$ psig on the anode and cathode, respectively. The test with the as-received CCM is identified as the baseline test.

The cell with the contaminated CCM is also tested at similar operating conditions. Since the cell performance could not reach to $400 \mathrm{~mA} / \mathrm{cm}^{2}$ due to the contamination, it is subjected to potentiostatic mode at the voltage average of the baseline test. After the 400 hours test, both the baseline and the contaminated cells are subjected to polarization curves, $\mathrm{CV}$, and cross over measurement for end of the test (EoT).

\subsubsection{MEA Cross-section Analysis}

After the test, the CCM of the baseline test and the contamination test as well as as-received CCM are examined using scanning electron microscope (SEM) (FEI Quanta 250, FEI, Hillsboro, OR, USA) and energy dispersive X-ray spectroscopy (EDX). The cross section samples of the CCMs are prepared using the epoxy coating method. For each CCM, multiple samples from fuel cell inlet, middle, and fuel cell outlet are examined, and elemental map and intensity profile (from line scans) of the cross-section is collected. For each sample, multiple line scans are collected and averaged to get the element intensity profile. To measure the thickness of the various layers of the CCMs, first, the interface of the layers are found from the first derivative of the average intensity profile, then the thickness are measured, and then the uncertainty in the thickness is determined from full width at half maximum (FWHM) of the intensity profile. 


\subsection{Results and discussion}

A galvanostatic performance test was performed for the baseline cell at $400 \mathrm{~mA} / \mathrm{cm}^{2}$. The voltage and cell resistance changes over time are given in Fig. 6.1. These data show that there is no significant change in cell voltage and cell resistance throughout the test. The cell voltage decay rate is $49 \mu \mathrm{V} / \mathrm{h}$ and the average cell voltage from $100 \mathrm{~h}$ to $300 \mathrm{~h}$ is $0.73 \mathrm{~V}$. The cell resistance is measured by current interrupt which includes the bulk membrane resistance, the GDL electronic resistance, and the contact resistance between fuel cell components. The average cell resistance is $56 \mathrm{~m} \Omega . \mathrm{cm}^{2}$. The breaks in the figure are due to power disruptions during the experiments.

Fig. 6.2 shows the comparative cell polarization curves were that measured at the beginning of the test (BoT) and at the end of the test (EoT). No distinct changes are observed in either the cell performance or the cell resistance after $400 \mathrm{~h}$ test. The average cell resistance is $43 \mathrm{~m} \Omega . \mathrm{cm}^{2}$ which is averaged across the polarization curves since the resistance changes as a function of current density. The average resistance during cell polarization is lower than the resistance during the current hold test as shown in Fig. 6.1. This is due to the variation in operating conditions.

Fig. 6.3 shows the ion exchange capacity (IEC) of the as-received CCM and the $\mathrm{Ca}^{2+}$ contaminated $\mathrm{CCM}$ which represents milli-equivalent of ion exchange group in $1 \mathrm{~g}$ dry ionomer. The IEC of the contaminated CCM is decreased by $58 \%$ compared to the as-received CCM. Since $\mathrm{Ca}^{2+}$ has higher affinity to sulfonic acid sites than proton, ${ }^{3,12}$ it replaces the proton resulting lower IEC value. For accuracy, the error bars are also presented. The experimental errors possibly come from the titration process and the calculation of the PFSA weight. 
Fig. 6.4 shows the liner sweep voltammetry (LSV) curves for the as-received and the contaminated CCM that is used to measure the $\mathrm{H}_{2}$ crossover from anode to cathode. The diffusion limiting currents for the as-received and the contaminated CCMs are 2.7 $\mathrm{mA} / \mathrm{cm}^{2}$ and $1.5 \mathrm{~mA} / \mathrm{cm}^{2}$, respectively. Faraday's law is used to calculate the hydrogen crossover flux and the values are $1.4 \times 10^{-8} \mathrm{~mol} / \mathrm{s} / \mathrm{cm}^{2}$ and $7.8 \times 10^{-9} \mathrm{~mol} / \mathrm{s} / \mathrm{cm}^{2}$ for the asreceived and the contaminated CCMs, respectively. The cations in the membrane decrease the hydrogen crossover about $44 \%$ and results corroborate well with previous reports. ${ }^{13}$ The decrease in hydrogen diffusion in the contaminated membrane can be explained by the changed flexibility of the polymer structure by the impurity ions. The cations (e.g. $\mathrm{Ca}^{2+}$ ) strongly interact with the ionic cluster in the polymer membrane which reduces the chains mobility and makes the polymer stiffer. ${ }^{3}$ Moreover, the shrinkage of hydrophilic domains and/or the cross-linking of cation exchange sites by cations would introduce a barrier for the hydrogen flux in the polymer network. ${ }^{14}$ The cationic impurities not only hinder the hydrogen transport but also the oxygen transport. Durst et al. reported that cation contamination increases the mass-transport resistance of molecular oxygen more than the proton resistance. ${ }^{15}$

Fig. 6.5 shows the polarization curves for the as-received $\mathrm{CCM}$ and the contaminated CCM. In case of the contaminated CCM, a much lower performance is observed compared to the as-received $\mathrm{CCM}$, and the performance drops drastically over all polarization regions namely, kinetic, ohmic, and mass transport region (Fig. 6.5a). The cell resistance also increases significantly for the contaminated CCM when compared to the as-received CCM. The average cell resistance of contaminated CCM is $217 \mathrm{~m} \Omega . \mathrm{cm}^{2}$, which is five times higher than the as-received CCM $\left(43 \mathrm{~m} \Omega \cdot \mathrm{cm}^{2}\right)$. The 
performance loss due to contamination can also be visualized through the power density plot as a function of current density (Fig. 6.5b). These plots indicate the peak power loss for the contaminated cell is around $90 \%$ as compared to as received CCM cell.

Since the performance of the contaminated CCM is low, it is not possible to run the cell at $400 \mathrm{~mA} / \mathrm{cm}^{2}$. Hence, the contaminated cell was tested in potentiostatic mode at an average potential equal to that of the baseline test for comparison. Fig. 6.6 shows the cell performance of the contaminated CCM tested at $0.73 \mathrm{~V}$. The cell voltage fluctuation after approximately 125 hours is due to the load bank that is operating near its lower power limit. It is observed that there is a sharp drop in performance during the first 125 hours of testing, and the current density decreases from $100 \mathrm{~mA} / \mathrm{cm}^{2}$ to $16 \mathrm{~mA} / \mathrm{cm}^{2}$. Then the current density becomes flat for next 275 hours, the current density drops only 3 $\mathrm{mA} / \mathrm{cm}^{2}$. However, it is not possible to get an accurate measurement of the cell resistance as the cell is running below the minimum current required by the test equipment.

The initial sharp performance drop may arise from the cation accumulation in the cathode electrode interface during fuel cell operation as well as a proton deficiency in the cathode resulting in kinetic and thermodynamic losses. ${ }^{16,17}$ Thermodynamic loss refers to shifts in the local electrochemical potential due to changes in proton activity which may be caused by a difference in concentration of proton between the cathode and anode electrodes, ${ }^{16,17}$ and kinetic loss arises from the increased activation overpotential needed at the electrode to drive the reaction faster as less protons are available for the reaction. ${ }^{17}$

Moreover, the oxygen reduction reaction (ORR) is reported to be suppressed by cation (e.g. $\mathrm{Ca}^{2+}$ ) contamination either through lowered oxygen gas transport or through suppressed charge transfer reactions by contaminant ions. It is reported that the 
suppression of ORR is specific to the metal catalyst/ionomer interface, not the metal catalyst/ liquid electrolyte interface, when cations enter the system. ${ }^{7,14}$ As mentioned earlier lower oxygen transport may arise from the polymer reorientation due to the rearrangement of the ion and water molecules and degradation in charge transfer reaction is also hypothesized to be the structural change of the electric double layer at the platinum/ionomer interface due to reorientation of the polymer network. Moreover, Durst et al. reported that the interactions between metal cations and the Pt surface enhance the adsorption of oxygen-containing species and therefore negatively impact the ORR kinetics. $^{15}$

Fig. 6.7 shows the representative membrane/electrode assembly cross sections (SEM), corresponding Pt maps (EDX), and average line scan profiles for the as-received CCM, the baseline test CCM, and the $\mathrm{Ca}^{2+}$ contaminated CCM after 400 hour tests. Table 6.1 summarizes the catalyst layer thickness and the average Pt intensity derived from SEM images. The cathode catalyst layer of the contaminated cell is indeed thinner at all over the active area of the CCM. The thickness of the cathode catalyst layer of the contaminated $\mathrm{CCM}$ reduces from $12 \mu \mathrm{m}$ to $6 \mu \mathrm{m}$. On the other hand, the cathode catalyst layer of the baseline test CCM essentially retains its initial thickness. A more critical inspection shows a locally thinner cathode catalyst layer only at the cell outlet of the baseline test (Fig. 6.8). But no location is found where the contaminated CCM retains its initial thickness.

There can be several reasons that can cause cathode catalyst layer thinning of contaminated CCM. One possible reason can be compaction of catalyst layer. The catalyst layer has a porosity of $40 \%^{16}$ and the pinch was $15 \%$ during cell building. 
Considering porosity along with pinch, the thickness of the catalyst layer cannot be reduced more than one micron. Although similar cell building procedure is for the baseline cell, there was no effect of compression. Moreover, anode catalyst layer remains unaffected for all the CCM. So the cathode catalyst layer thinning due to compaction can be ruled out.

Another possible reason can be the loss of materials from the cathode catalyst layer. The cathode catalyst layer of the contamination test CCM losses half of its thickness, but the total Pt content is unchanged. We reach this conclusion because, the total Pt intensity is unaffected (Table 6.1), the Pt signal looks much brighter in the map, and the Pt intensity is also higher in the line scan. Therefore there is no change in Pt content in cathode catalyst layer and the only possible element loss that may cause significant catalyst layer thickness change is carbon. Since cationic contaminant tends to accumulate in the cathode region during fuel cell operation as reported through modeling ${ }^{16,18,19}$ as well as experimental results shown in Fig.6.9, it is hypothesized that the $\mathrm{Ca}^{2+}$ ion either directly or indirectly increases the carbon oxidation reaction rate resulting in catalyst layer thinning of the cathode. But the detailed mechanism is currently unknown.

\subsection{Conclusion}

Two polymer electrolyte fuel cells, one with an as-received CCM and the other one with a $\mathrm{Ca}^{2+}$ contaminated CCM are subjected to a 400 hour stability test. The cell performance of the contaminated CCM is very low and the cell resistance is higher when compared to the as-received CCM. The cell with the as-received CCM is tested at $400 \mathrm{~mA} / \mathrm{cm}^{2}$. Since the performance of contaminated CCM is lower than $400 \mathrm{~mA} / \mathrm{cm}^{2}$, 
the cell is tested in the potentiostatic mode at the average potential of the baseline test. After the test, the cathode catalyst layer of the contaminated CCM is found to lose half of its original thickness over the full active area of the CCM, compared to baseline test CCM. Results from the EDX elemental map and the intensity profile analysis, it is found that there is no change in Pt content in catalyst layer and the only possible element loss may cause that much catalyst layer thickness change is carbon. The total mechanism behind the catalyst layer thinning is currently unknown. 


\subsection{References}

1. T. Okada, J. Electroanal. Chem., 465, 1 (1999).

2. T. Okada, J. Electroanal. Chem., 465, 18 (1999).

3. T. Okada, N. Nakamura, M. Yuasa and I. Sekine, J. Electrochem. Soc., 144, 2744 (1997).

4. T. Okada, G. Xie, O. Gorseth, S. Kjelstrup, N. Nakamura and T. Arimura, Electrochim. Acta, 43, 3741 (1998).

5. T. Okada, S. Møller-Holst, O. Gorseth and S. Kjelstrup, J. Electroanal. Chem., 442, 137 (1998).

6. T. Okada, Y. Ayato, M. Yuasa and I. Sekine, J. Phy. Chem. B, 103, 3315 (1999).

7. T. Okada, in Handbook of Fuel Cells-Fundamentals, Technology and Applications, W. Vielstich, H. A. Gasteiger, A. Lamm and H. Yokokawa, Editors, John Wiley \& Sons, Ltd, New York (2010).

8. M. Saito, N. Arimura, K. Hayamizu and T. Okada, J. Phy. Chem. B., 108, 16064 (2004).

9. M. J. Kelly, G. Fafilek, J. O. Besenhard, H. Kronberger and G. E. Nauer, J.Power Sources, 145, 249 (2005).

10. J. Qi, X. Wang, U. Pasaogullari, L. Bonville and T. Molter, J. Electrochem. Soc., 160, F916 (2013).

11. M. J. Kelly, B. Egger, G. Fafilek, J. O. Besenhard, H. Kronberger and G. E. Nauer, Solid State Ionics, 176, 2111 (2005).

12. K. Hongsirikarn, J. G. Goodwin, S. Greenway and S. Creager, J. Power Sources, 195, 7213 (2010).

13. T. Molter, The effects of cationic contamination on the physio-chemical properties of perfluoroionomer membranes, $\mathrm{PhD}$ Dissertation, ETD Collection for University of Connecticut, Paper AAI3314616 ( 2008).

14. T. Okada, Y. Ayato, J. Dale, M. Yuasa, I. Sekine and O. A. Asbjørnsen, Phy. Chem. Chem. Phy., 2, 3255 (2000).

15. J. Durst, M. Chatenet and F. Maillard, Phy. Chem. Chem. Phy., 14, 13000 (2012).

16. M. A. Uddin and U. Pasaogullari, J. Electrochem. Soc., 161, F1081 (2014).

17. B. Kienitz, B. Pivovar, T. Zawodzinski and F. H. Garzon, J. Electrochem. Soc., 158, B1175 (2011).

18. B. Kienitz, H. Baskaran and T. Zawodzinski, Electrochim. Acta., 54, 1671 (2009).

19. M. F. Serincan, U. Pasaogullari and T. Molter, Int. J. Hydrogen Energy, 35, 5539 (2010). 
Table 6.1. Average catalyst layer thickness and Pt intensity of as-received, baseline test, and $\mathrm{Ca}^{2+}$ contamination test $\mathrm{CCM}$.

\begin{tabular}{ccccc}
\hline CCM & $\begin{array}{c}\text { Average cathode } \\
\text { thickness }(\boldsymbol{\mu m})\end{array}$ & $\begin{array}{c}\text { Average anode } \\
\text { thickness }(\boldsymbol{\mu m})\end{array}$ & $\begin{array}{c}\text { Average cathode } \\
\text { Pt intensity }\end{array}$ & $\begin{array}{c}\text { Average anode } \\
\text { Pt intensity }\end{array}$ \\
& $(\mathbf{\pm 1})$ & $(\mathbf{+ 1 )}$ & $(\mathbf{\pm 1 0 0})$ & $(\mathbf{\pm 1 0 0})$ \\
\hline As-received & 12 & 11.75 & 3000 & 2900 \\
Baseline test & 10 & 11 & 2860 & 2800 \\
$\mathrm{Ca}^{2+}$ contamination test & 6 & 11 & 2850 & 3000 \\
\hline
\end{tabular}




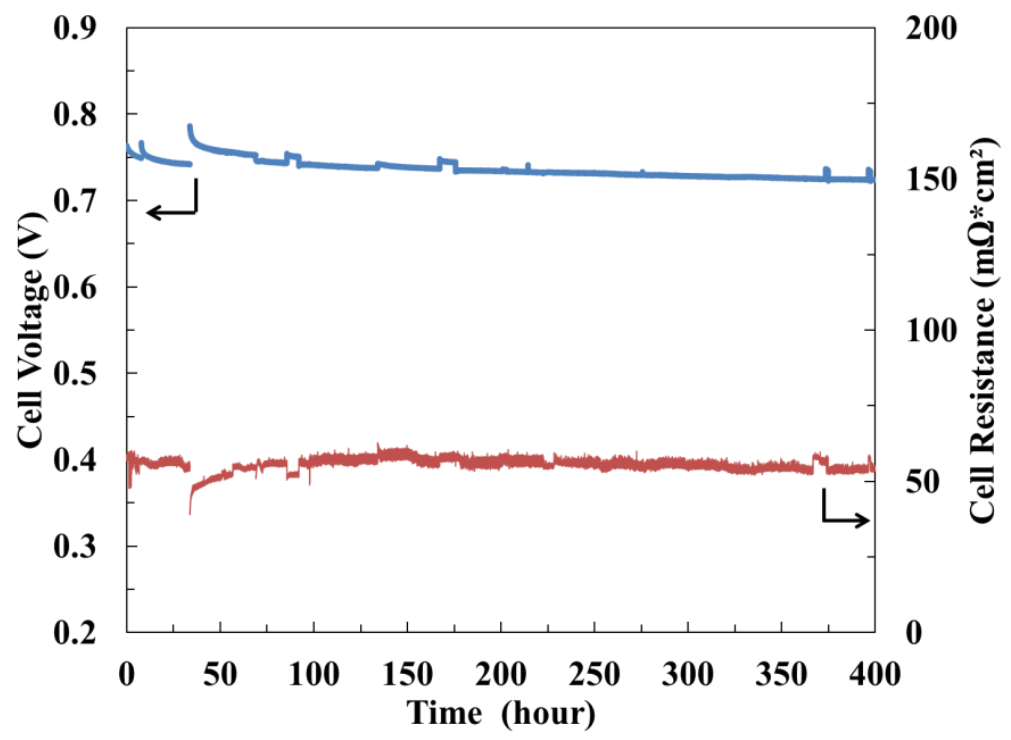

Fig. 6.1. Cell performance of the as-received CCM measured at $400 \mathrm{~mA} / \mathrm{cm}^{2}$. Operating conditions: cell temperature: $80^{\circ} \mathrm{C}$; flow rate $\mathrm{H}_{2} /$ air: $1.66 / 1.75 \mathrm{slpm}$; $\mathrm{A} / \mathrm{C}$ : $25 / 125 \% \mathrm{RH}$, 1.5/15 psig back pressure. 

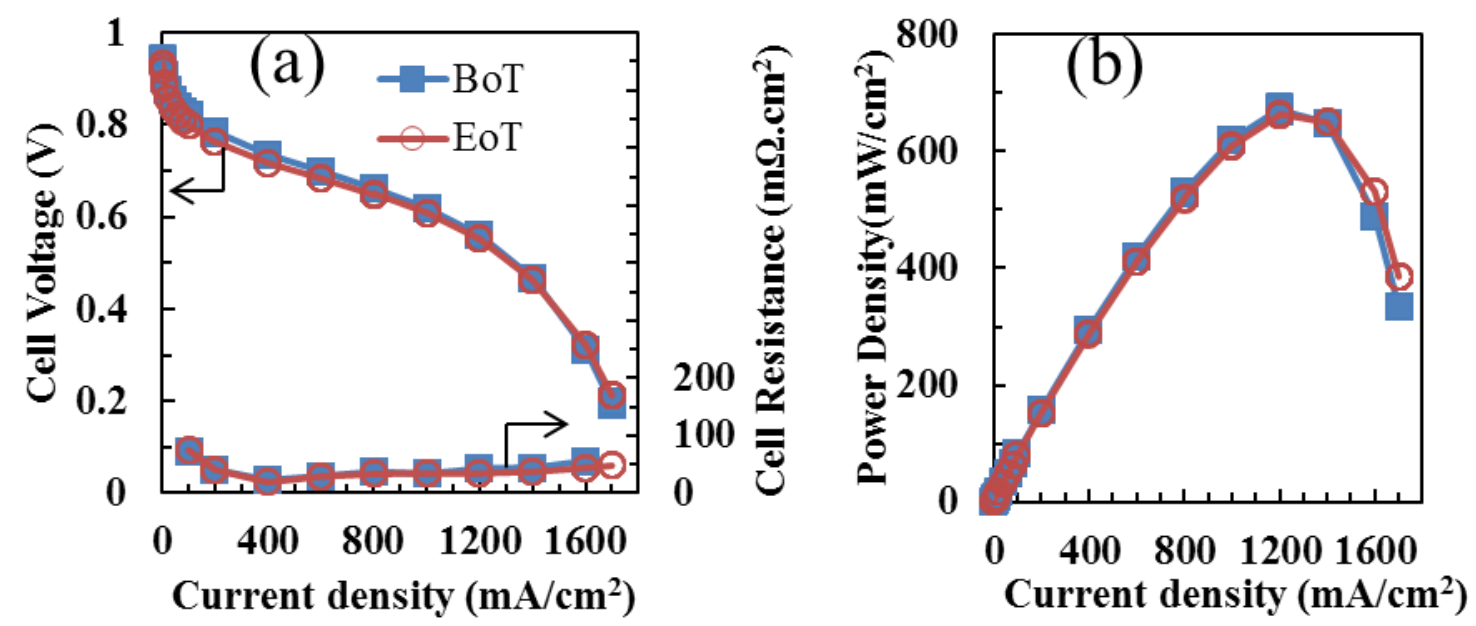

Fig. 6.2. (a) Polarization curves and (b) power density curves measured at the beginning of the baseline test (BoT) and at the end of the baseline test (EoT). Operating conditions: cell temperature: $80{ }^{\circ} \mathrm{C}$; minimum flow rate $\mathrm{H}_{2} /$ air: $200 \mathrm{sccm}$; $\mathrm{A} / \mathrm{C}: 2 / 2$ stoic, $100 / 75 \%$ RH, 0/0 psig back pressure. 


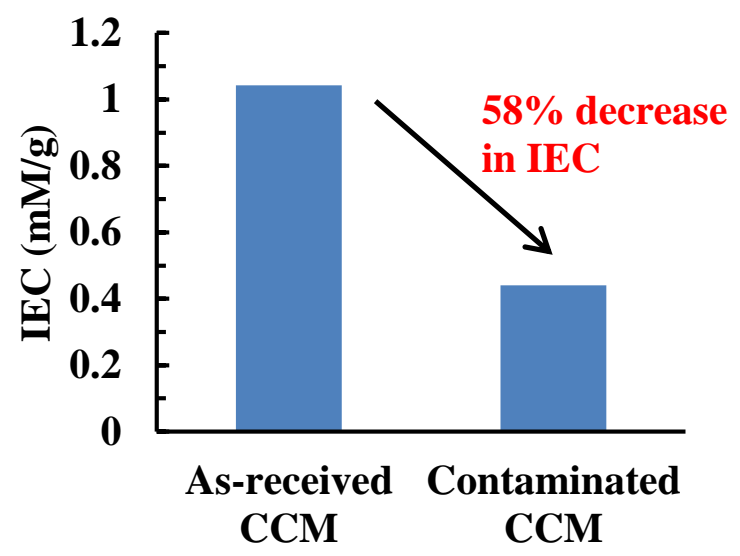

Fig. 6.3. Comparative ion exchange capacity (IEC) values for as-received and contaminated CCMs. 


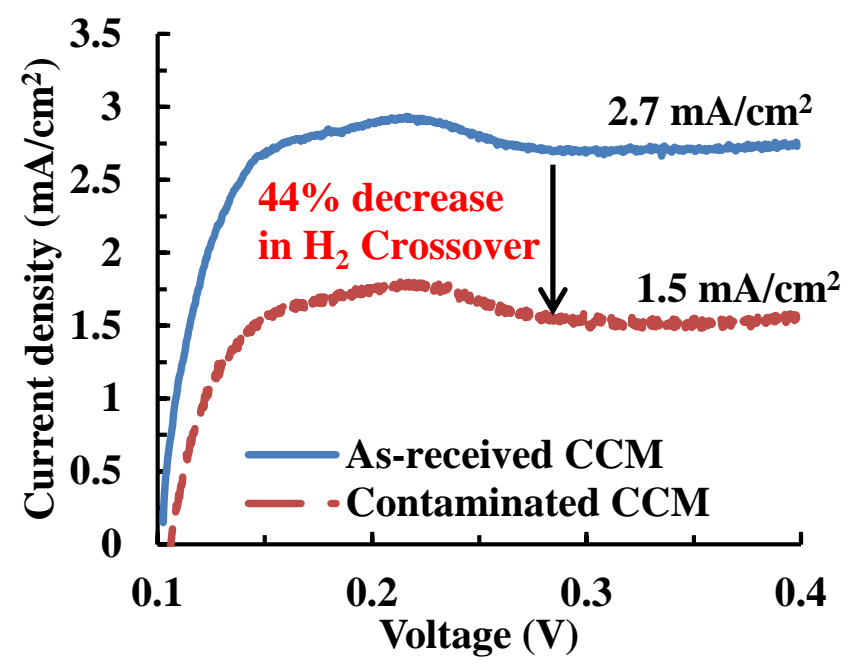

Fig. 6.4. Comparison of $\mathrm{H}_{2}$ crossover of as-received and contaminated CCM. Operating conditions: $80^{\circ} \mathrm{C}$, flow rate $\mathrm{H}_{2} / \mathrm{N}_{2}: 250 / 250 \mathrm{sccm}, \mathrm{A} / \mathrm{C}: 25 / 125 \% \mathrm{RH}, 0 / 0$ psig back pressure, scan rate: $5 \mathrm{mV} / \mathrm{s}$. 

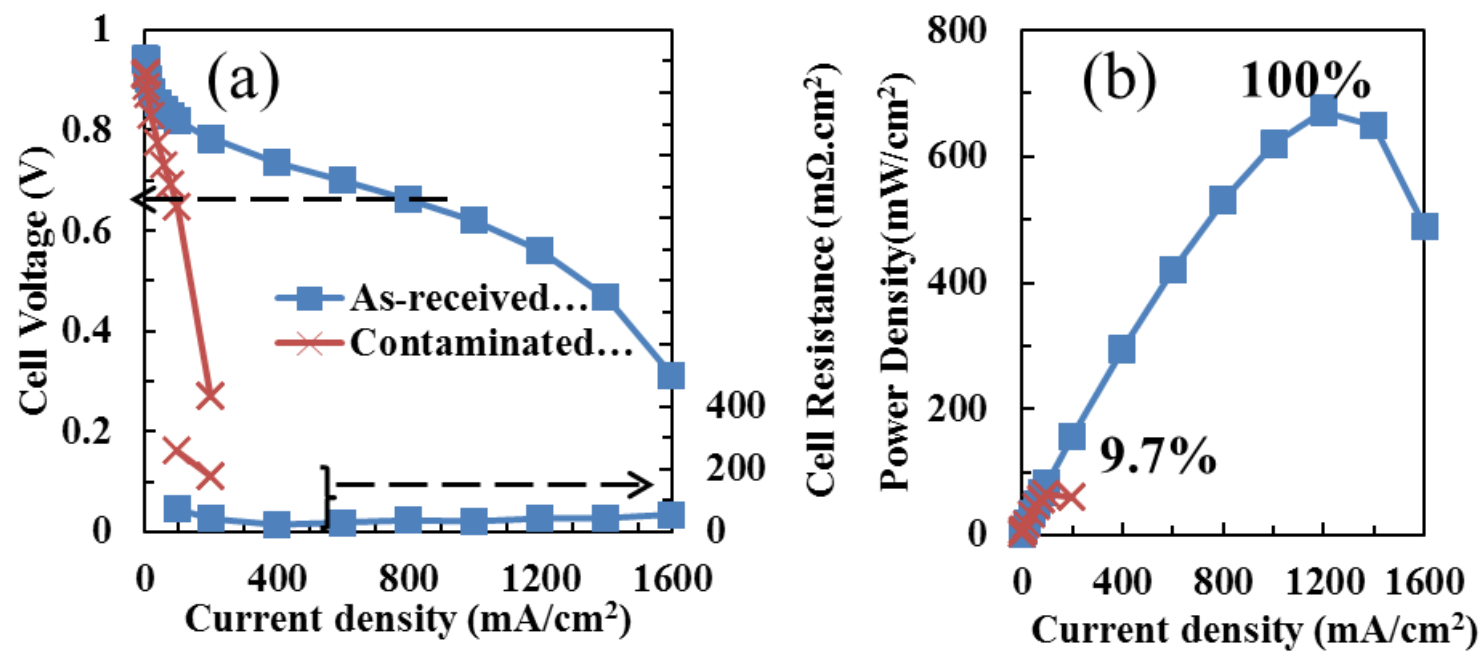

Fig. 6.5. (a) Polarization curves (b) power density curves of as-received CCM and contaminated CCM. Operating conditions: cell temperature: $80^{\circ} \mathrm{C}$; minimum flow rate $\mathrm{H}_{2} /$ air: $200 \mathrm{sccm}$; A/C: 2/2 stoic, 100/75\% RH, 0/0 psig back pressure. 


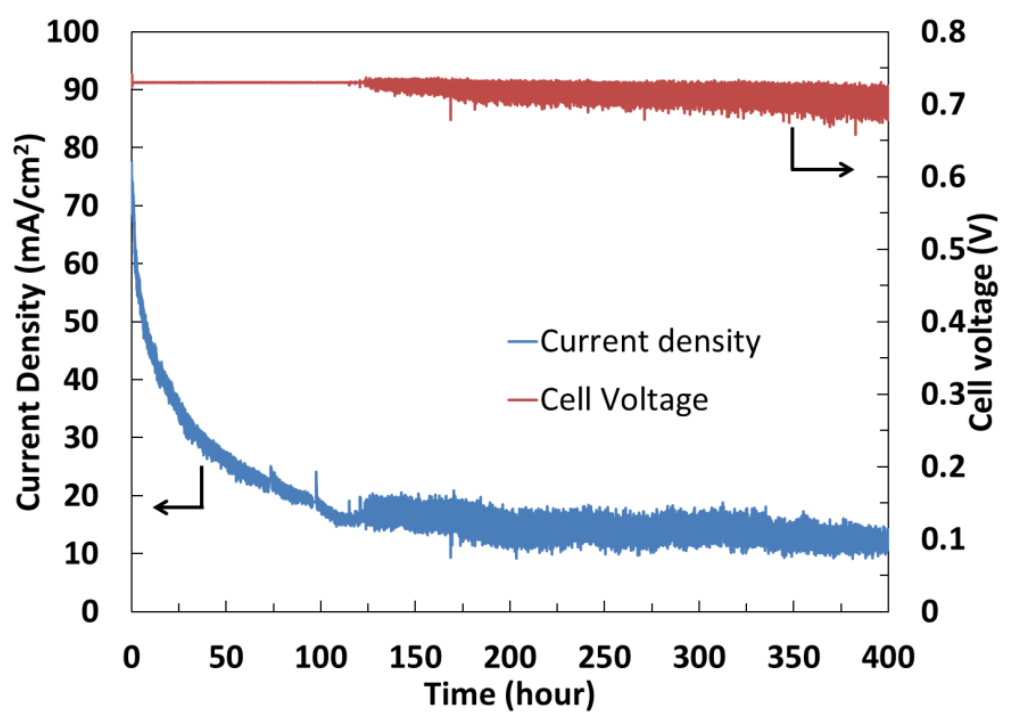

Fig. 6.6. Cell performance of contaminated CCM measured at $0.73 \mathrm{~V}$. Operating conditions: cell temperature: $80^{\circ} \mathrm{C}$; flow rate $\mathrm{H}_{2} /$ air: $1.66 / 1.75 \mathrm{slp}$; $\mathrm{A} / \mathrm{C}: 25 / 125 \% \mathrm{RH}$, 1.5/15 psig back pressure. 


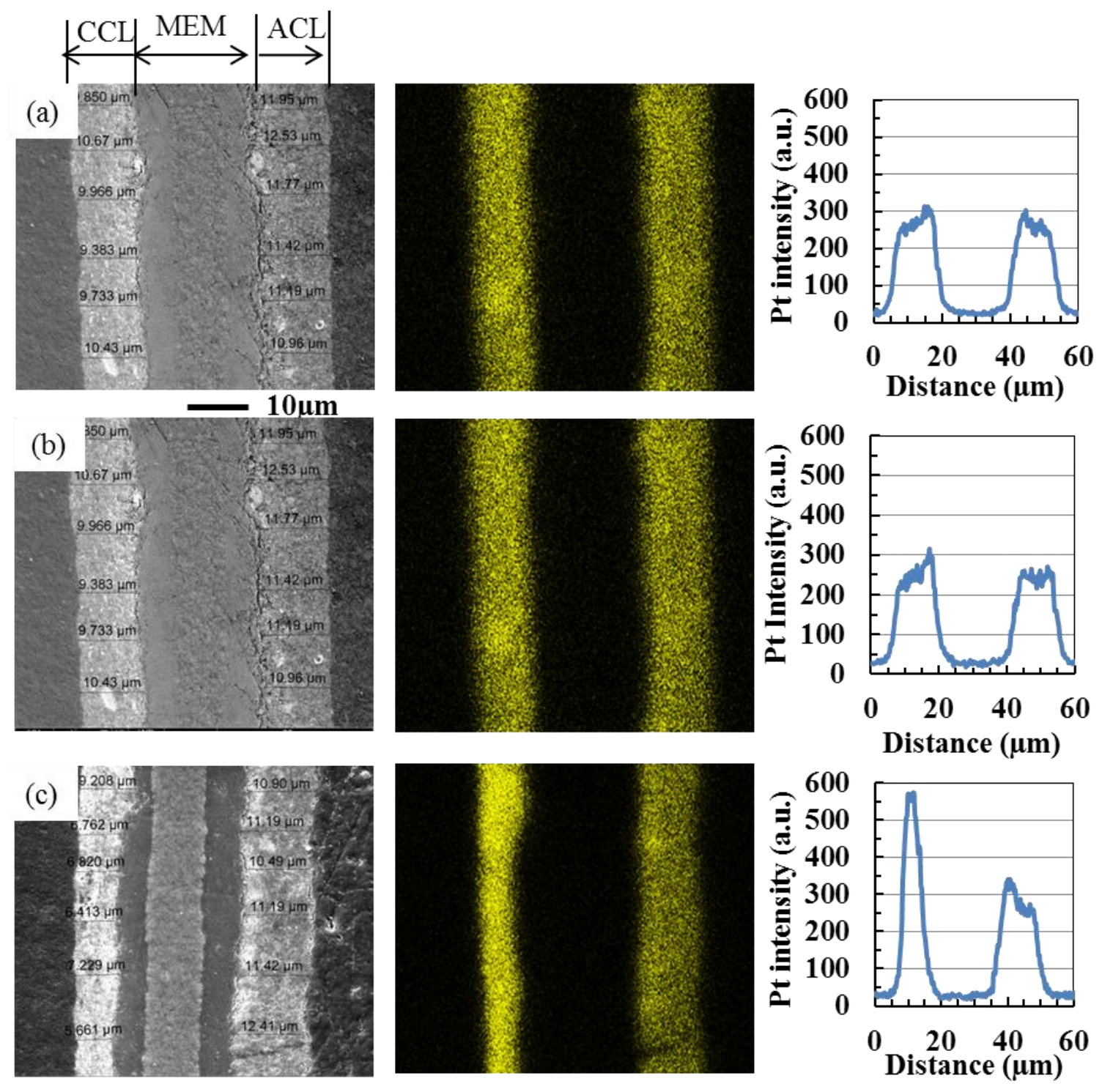

Fig. 6.7. Membrane/electrode assembly cross sections imaged by SEM (left), corresponding Pt maps (middle), and average line scan (right) of (a) as-received CCM, (b) baseline test CCM, and (c) $\mathrm{Ca}^{2+}$ contaminated CCM after 400 hour fuel cell test. (CCL-cathode catalyst layer, MEM-membrane, ACL-anode catalyst layer). 

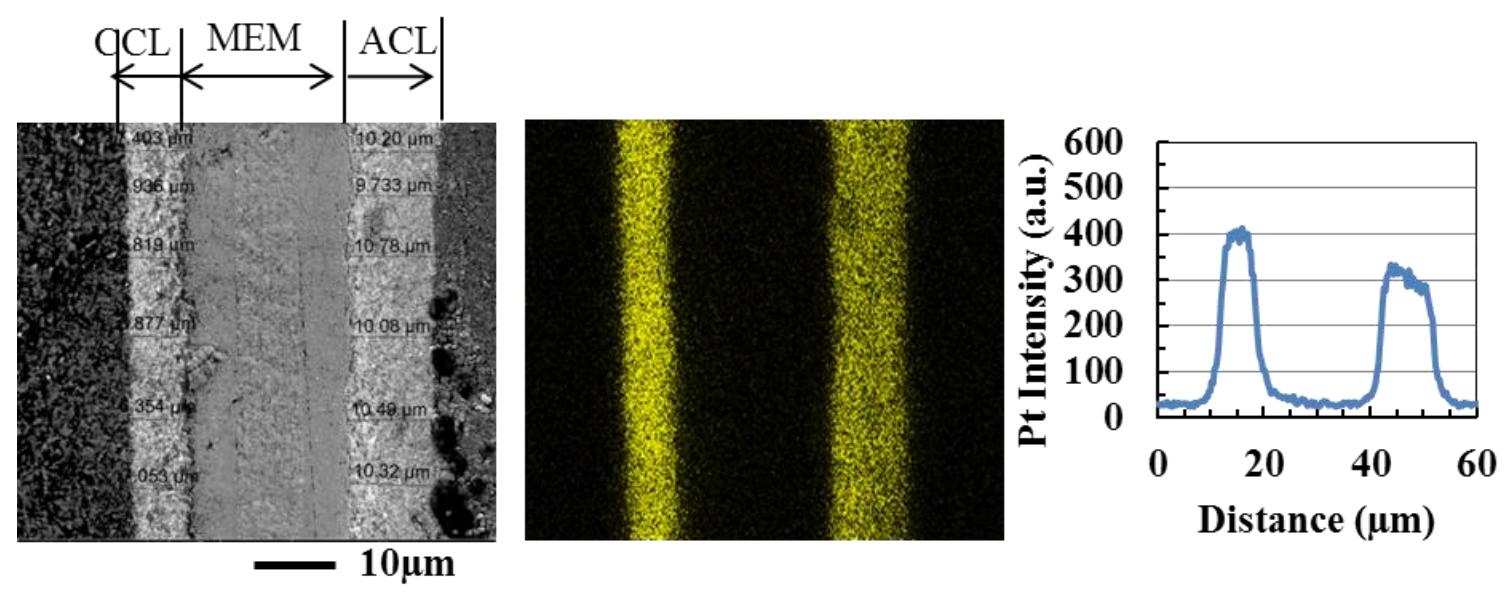

Fig. 6.8. Localized catalyst layer thinning in baseline test. Membrane/electrode assembly cross sections imaged by SEM (left), corresponding Pt maps (middle), and Pt line scan (right) after a long duration fuel cell baseline test. (CCL-cathode catalyst layer, MEMmembrane, ACL-anode catalyst layer). 

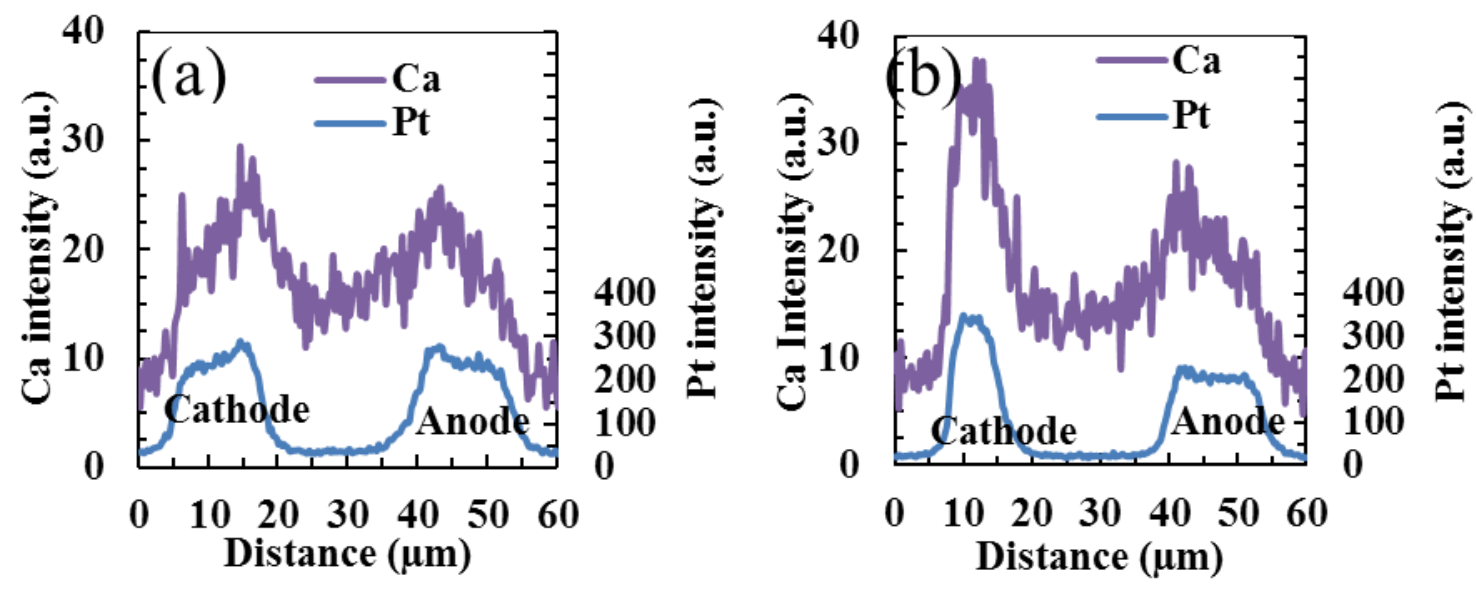

Fig. 6.9. Cation profile in contaminated CCM (a) just after soak in cation solution and (b) after 400 hour durability test. 


\section{CATION CONTAMINATION AND MITIGATION IN POLYMER ELECTROLYTE FUEL CELLS}

\subsection{Introduction}

We observed that water management significantly affects contamination by cations which may result in salt precipitation in the GDL and the flow field causing serious mass transport losses. ${ }^{1-6}$ It was seen that the GDL played an important role in the transport of cations. Moreover, when the membrane directly comes into contact with cations, its proton conductivity and gas permeability decreases causing serious performance loss. To address the above mentioned contamination mechanisms, we have adopted following mitigation strategies:

$\checkmark$ Mitigation of contaminated membrane via ex-situ method

$\checkmark$ Mitigation of salt deposit from the GDL and flow field via ex-situ acid flush.

\subsection{Experimental}

The details of the experimental setup and the test procedure were described in elsewhere. ${ }^{1-3,7}$ Briefly, $25 \mathrm{~cm}^{2}$ active area identical cells were tested in a fuel cell test station (Teledyne MEDUSA RD, TELEDYNE Energy Systems, Inc., MA) interfaced with a Scribner 890C load box (Scribner Associates Inc. NC, USA). The MEA was prepared with a catalyst coated membrane (CCM) with a Pt loading of $0.4 \mathrm{mg} \mathrm{cm}^{-2}$ in the

anode and the cathode catalyst layers $\left(\right.$ Gore $^{\mathrm{TM}}$ PRIMEA $^{\circledR}$, W.L. Gore\& Associates Inc., 
Elkton, MD) and two Freudenberg C4 (Freudenberg FCCT SE \& Co. KG, Germany) gas diffusion layers (GDLs).

\subsubsection{Membrane contamination and mitigation}

The cell was conditioned overnight at constant voltage $(0.6 \mathrm{~V})$ and then the cell was run with pure air for 24 hours. Then the cell was disassembled and an ex-situ soak method is utilized to add foreign cations into the MEA. This method essentially involved soaking the MEA in a solution of $0.9 \mathrm{mM} \mathrm{CaSO}_{4}\left(\mathrm{CaSO}_{4}, 99.99 \%\right.$ pure metal basis, Sigma-Aldrich $^{\circledR}$, St. Louis, MO) and $29.1 \mathrm{mM} \mathrm{H}_{2} \mathrm{SO}_{4}$, with a major difference being whether the sealing gaskets and/or the gas diffusion layers (GDL) are included in the soaked assembly in various tests. Fig. 7.1 and Table 7.1 show all configurations used to soak the MEA in contaminant solution. Contaminated membrane was re-protonated in an acidic solution similar to Qi et $_{\text {al. }}{ }^{7}$

\subsubsection{GDL/flow field contamination and mitigation}

A regular $25 \mathrm{~cm}^{2}$ cell was tested using a testing procedure mentioned in chapter 2, section 2.2.3. The contaminant was calcium sulfate solution. The flow rate of the calcium sulfate solution was $65 \mu \mathrm{Lmin}$ with a concentration of $1.14 \mathrm{mM}$ which corresponds to 5 ppm flow in air stream on mole basis.

Recovery tests were performed after cell operation with the presence of $\mathrm{Ca}^{2+}$ ions that led to salt deposits in the flow field channels and the gas diffusion electrode .To remove salt deposit at cathode GDL, ex-situ cleaning methods have been adopted. For this, $100 \mathrm{mM} \mathrm{H}_{2} \mathrm{SO}_{4}$ solution with $80 \mathrm{ml} / \mathrm{min}$ flow rate passed through cathode for 2.5 hours, while keeping anode side filled with water, subsequently cathode was circulated 
with DI water for 2 hours. The schematic illustration of Ex-situ cleaning method is given in Fig. 7.2.

\subsection{Results and discussion}

\subsubsection{Membrane contamination}

Fig. 7.3 shows the polarization curves obtained immediately after soaking in foreign cation solution with all the configurations shown in Fig. 7.1. For comparison, a reference uncontaminated baseline is also shown in Fig. 7.3. As clearly visible from Fig. 7.3 , the foreign cation uptake, which controls the cell performance, is very strongly dependent on the soak configuration. We see significant but not the same performance

drop in methods $\mathrm{A}$ and $\mathrm{B}$ due to the presence of $\mathrm{Ca}^{2+}$ inside the $\mathrm{CCM}$ (Fig. 7.4), although soaking time in method B (100 hours) was 4 times higher than method A (24 hours), and no significant performance change in method C (soaking time 100 hours). So even increasing the soaking time to more than 4 times in method $\mathrm{C}$ compared to method A, cell performance did not change significantly. We conclude from these tests that the GDL acted as a barrier to the transport of foreign cations $\left(\mathrm{Ca}^{2+}\right)$ into the $\mathrm{CCM}$, possibly due to very highly hydrophobic nature of the GDL, especially in the micro-porous layer next to the catalyst layers. When a wetting agent (1\% isopropanol) was added to the cationic solution to increase the wettability of the GDL with the same MEA, which was used to measure the curve $\mathrm{C}$, a drop in the performance was observed, even though 1\% IPA did not make the GDL fully hydrophilic.

To increase the wettability of the GDL, we tested four wetting agents: Triton$\mathrm{X}$ (Tri), isopropanol (IPA), ethanol, and methanol, and measured the wettability of the 
GDL with $1 \%$ of these compounds in DI water. Fig. 7.5a shows a sessile droplet showing the characteristic dimensions of the droplet. The ratio of minor axis (L2) to major axis (L1) represents the wettability of the GDL. By convention the GDL is defined as hydrophilic when the ratio becomes less than 0.5. Fig. 7.5 (b-c) shows that DI water with $1 \%$ of the above mentioned compounds did not wet the GDL, but Triton-X worked better. For Triton-X, it took $20 \%$ of triton-X to make both sides of the GDL hydrophilic (Fig. 7.5(d-e)), but it was found that 5\% triton-x dissolved and detached the catalyst layer (CL) from the CCM surface (Fig. 7.5f) rendering this compound unusable for this purpose. With IPA, it took more than 25\% IPA in DI water to render both sides of the GDL hydrophilic (Fig. 7.5(g-i)).

Then to check whether IPA damaged the CL from the CCM, the CCM is soaked in different volume fraction of IPA at $25^{\circ} \mathrm{C}$ and $80^{\circ} \mathrm{C}$ for $24 \mathrm{~h}$ (Fig. 7.6). At $25^{\circ} \mathrm{C}, 30 \%$ IPA dissolved and detached the CL layer from CCM while no change occurred for 10\%$20 \%$ IPA. However at $80^{\circ} \mathrm{C}, 20 \%$ IPA detached the CL layer from CCM. No change was seen for $10 \%$ and $15 \%$.

Even after drying the GDL, which was soaked in $15 \%$ IPA at $80^{\circ} \mathrm{C}$ for $24 \mathrm{~h}, \mathrm{MPL}$ remained hydrophilic (Fig. 7.7). Therefore, 15\% IPA was selected as the wetting agent, although there was some concern that IPA itself might be a contaminant. Previous testing has shown that the performance loss due to IPA was recoverable. ${ }^{8}$

When $15 \%$ isopropanol was added to the contaminant solution to increase the wettability of the GDL and MEA with a configuration of method C (shown in Fig. 7.1 and Table 7.1) and soaked for 100h, a significant drop in the performance was observed which was close to the curve B (Fig. 7.3). So, that confirms that wettability of the GDL 
plays an important role to the transport of cations to the CCM through the GDL, and high fractions of IPA as a wetting agent can be used to transport cation solutions across the GDL into the CCM.

\subsubsection{Mitigation of membrane contamination}

Since the GDL acted as a barrier to transport of cationic solution, we hypothesize that it may also hinder the cell performance recovery with re-protonation. We reprotonated only the CCMs in an acidic solution similar to Qi et al. ${ }^{7}$ Polarization curves were conducted in sequence by following a multiple steps process of contaminating the CCM using method A (shown in Fig. 7.1), constant current hold operation, and reprotonation. This procedure required the cell to be disassembled and re-assembled twice. Results are shown in Fig. 7.8, which indicate the cell degraded after $\mathrm{Ca}^{2+}$ exposure (beginning of test (BoT)), lost significant performance during current hold operation (End of test (EoT)) possibly due to redistribution and accumulation of foreign cations at the cathode, and was mostly recovered by reprotonation by using acidic solution, but it was not fully recovered contrary to Qi et al. 's findings. ${ }^{7}$ When the GDL was removed from the CCM prior to reprotonation, part of MPL may have remained attached to the CCM surface acting as a barrier to the transport of foreign cations out of the CCM during reprotonation.

\subsubsection{Mitigation of GDL/flow field contamination}

Similar to our previous studies reported by Wang et $a l .{ }^{4}$, the cell was tested and disassembled and subjected to initial visual observation. Then the ex-site acid flush was done. Fig. 7.9 shows the comparative images of cathode flow field and GDL before and 
after ex-site acid cleaning. It shows that salt deposit at flow field is completely removed, whereas in GDL there are some white patches of salt deposit still observed. In another words, the recovery procedure was largely effective (Fig. 7.9) but characterization tests still revealed an incomplete performance recovery and the presence of salts.

Fig. 7.10 shows polarization curves indicate that the cell performance was only improved slightly in the mass transfer regime. Cyclic voltammograms (Fig. 7.11) also shows that the in situ recovery procedure (acid only) was insufficient to affect the catalyst ionomer as the Pt surface area was not restored to its original value.

Fig. 7.10 and Fig. 7.11 results are supported by the presence of remnant salt deposits (Fig. 7.12, top) in the gas diffusion electrode (Fig. 7.12, bottom) as detected by energy dispersive x-ray spectroscopy (EDX). No cations were detected in the catalyst layer and the membrane; however they may still be present below the EDX detection limit.

The membrane/electrode assembly cross section as observed by scanning electron microscopy (bottom left) shows from the image top the cathode gas diffusion layer, the catalyst coated membrane with its support in the middle and the cathode gas diffusion layer with salt deposits in white. The $\mathrm{S}$ (bottom center) and $\mathrm{Ca}$ (bottom right) energy dispersive x-ray spectroscopy maps correlate with the cathode salt deposits.

\subsection{Conclusion}

The effect of GDL in cation contamination and mitigation was investigated using three different MEA configurations major difference being whether the CCM was completely/partially exposed to the cationic solution or fully separated by the GDL and gasket. It was seen that the hydrophobic nature of the GDL acted as a barrier for cation 
solutions to reach the CCM, which was further verified using a wetting agent in cationic solution. Based on this, we hypothesize that GDL acts as a barrier for foreign cations to exit the CCM as well. We also demonstrated that the cell performance can be mostly recovered by the reprotonation of only the CCM. 


\subsection{References}

1. M. A. Uddin, X. Wang, J. Qi, M. O. Ozdemir, L. J. Bonville, U. Pasaogullari and T. Molter, ECS Trans., 58(1), 543 (2013).

2. X. Wang, J. Qi, O. Ozdemir, U. Pasaogullari, L. J. Bonville and T. Molter, ECS Trans., 58(1), 529 (2013).

3. J. Qi, X. Wang, O. Ozdemir, M. A. Uddin, L. J. Bonville, U. Pasaogullari and T. Molter, ECS Trans., 58(1), 537 (2013).

4. X. Wang, U. Pasaogullari, J. Qi, O. Ozdemir, M. A. Uddin, L. Bonville, and T. Molter, J. Electrochem. Soc., 161, F1006 (2014).

5. M.A. Uddin, J. Qi, X. Wang, M.O. Ozdemir, N.K.H. Dalasm, L. Bonville, U. Pasaogullari, T. Molter, ECS Trans. 61(12), 37 (2014).

6. M. A. Uddin, X. Wang, M. O. Ozdemir, J. Qi, L. J. Bonville, U. Pasaogullari and T. Molter, T. Molter, ECS Trans. 61(12), 49 (2014).

7. J. Qi, X. Wang, U. Pasaogullari, L. Bonville and T. Molter, J. Electrochem. Soc., 160, F916 (2013).

8. J. St-Pierre, Y. Zhai and M. S. Angelo, J. Electrochem. Soc., 161, F280 (2014). 
Table 7.1. MEA contamination methods

\begin{tabular}{|c|c|c|c|c|}
\hline Method & Method description & Soaking solution & $\begin{array}{c}\text { Soaking } \\
\text { time } \\
\text { (hours) }\end{array}$ & $\begin{array}{l}\text { Wetting } \\
\text { agent }\end{array}$ \\
\hline A & $\begin{array}{c}\text { The CCM is in direct contact } \\
\text { with the } \mathrm{Ca}^{2+} \text { solution }\end{array}$ & $\begin{array}{l}0.9 \mathrm{mM} \mathrm{CaSO}_{4}+ \\
29.1 \mathrm{mM} \mathrm{H}_{2} \mathrm{SO}_{4}\end{array}$ & 24 & - \\
\hline B & $\begin{array}{l}\text { Portion of the CCM is in direct } \\
\text { contact with the } \mathrm{Ca}^{2+} \text { solution. }\end{array}$ & $\begin{array}{l}0.9 \mathrm{mM} \mathrm{CaSO}_{4}+ \\
29.1 \mathrm{mM} \mathrm{H}_{2} \mathrm{SO}_{4}\end{array}$ & 100 & - \\
\hline C & $\begin{array}{l}\text { The CCM is not in direct contact } \\
\text { with the solution being separated } \\
\text { by both the GDL and a gasket }\end{array}$ & $\begin{array}{l}0.9 \mathrm{mM} \mathrm{CaSO}_{4}+ \\
29.1 \mathrm{mM} \mathrm{H}_{2} \mathrm{SO}_{4}\end{array}$ & 100 & - \\
\hline $\mathrm{D}$ & Method $\mathrm{C}$ with wetting agent & $\begin{array}{l}0.9 \mathrm{mM} \mathrm{CaSO}_{4}+ \\
29.1 \mathrm{mM} \mathrm{H}_{2} \mathrm{SO}_{4}\end{array}$ & 100 & $1 \%$ IPA \\
\hline $\mathrm{E}$ & Method $\mathrm{C}$ with wetting agent & $\begin{array}{l}0.9 \mathrm{mM} \mathrm{CaSO}_{4}+ \\
29.1 \mathrm{mM} \mathrm{H}_{2} \mathrm{SO}_{4}\end{array}$ & 100 & $15 \%$ IPA \\
\hline
\end{tabular}


(a)
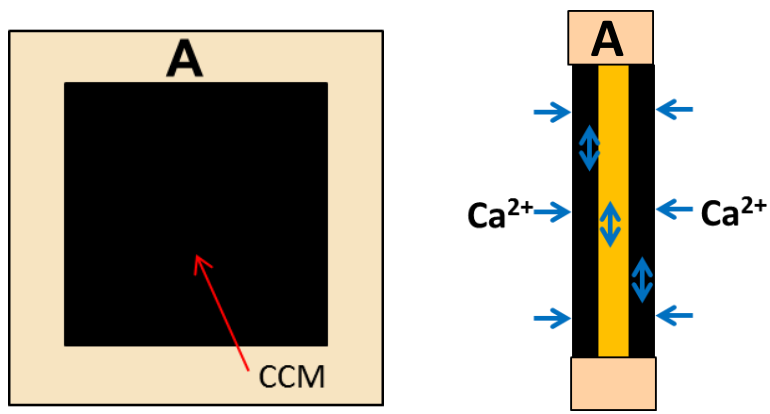

(b)
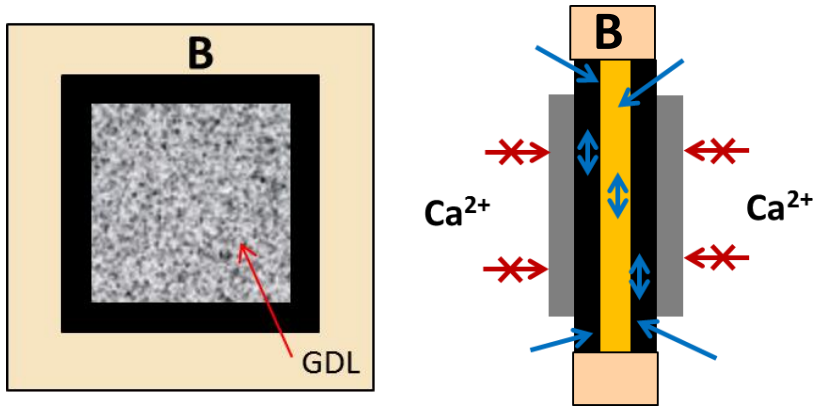

(c)
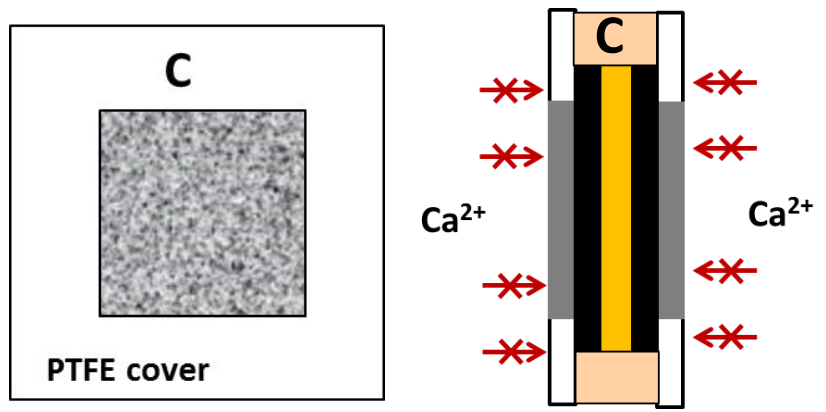

Fig. 7.1. MEA contamination method: (a) A: The CCM is in direct contact with the $\mathrm{Ca}^{2+}$ solution. (b) B: The CCM is only in direct contact with the $\mathrm{Ca}^{2+}$ solution only at its periphery because the solution does not wet the GDL. (c) C: The CCM is not in direct contact with the solution being separated by both the GDL and a gasket. 


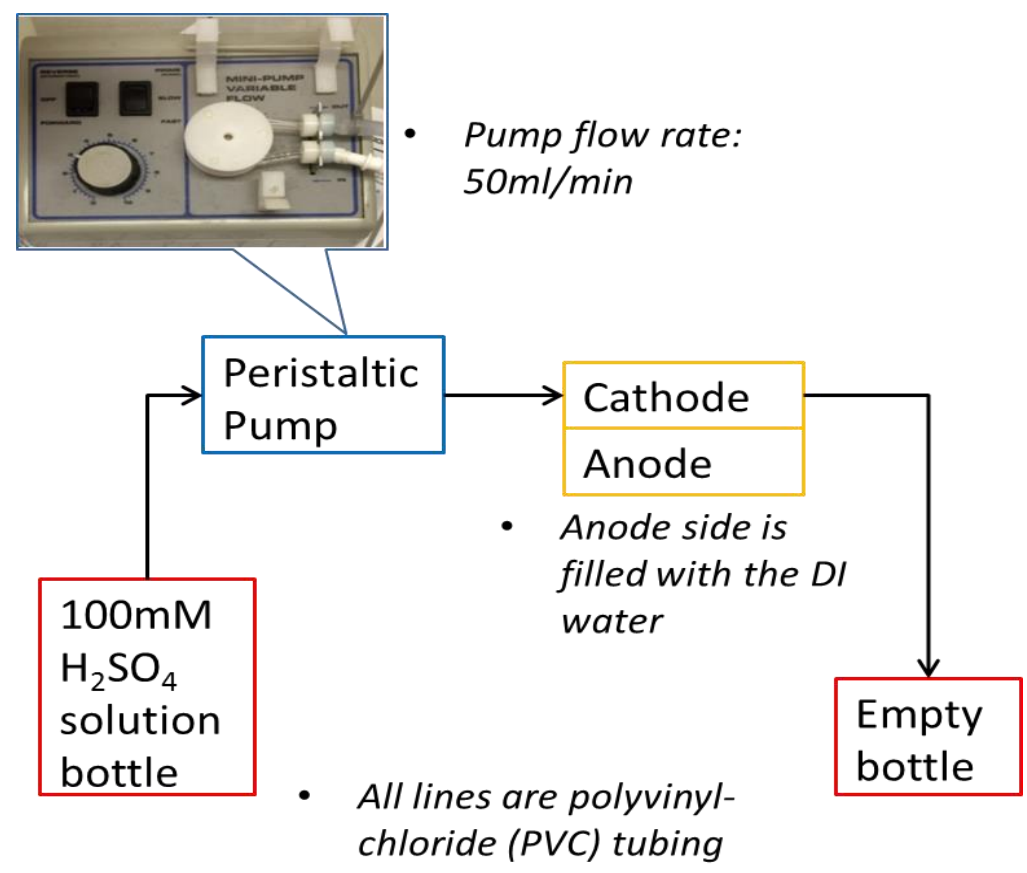

Fig. 7.2. Schematic of experiment setup for ex-situ cleaning by acid flush. 


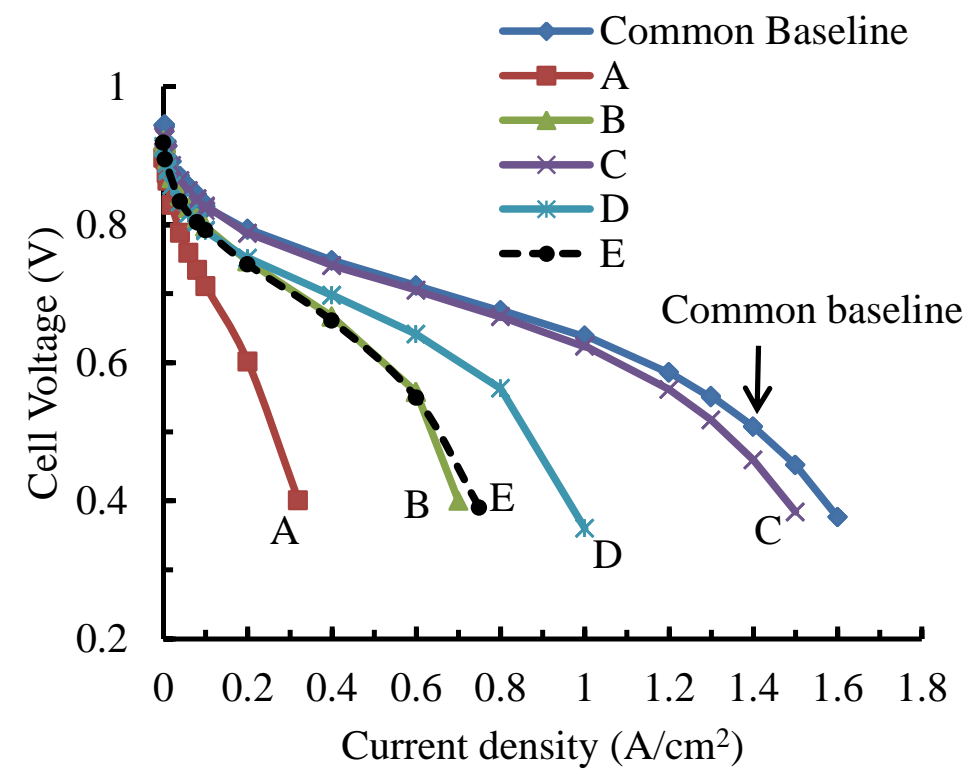

Fig. 7.3. Comparison between a baseline polarization curve and others obtained after different $\mathrm{Ca}^{2+}$ exposure methods (see Fig. 7.1 and Table 7.1). $80{ }^{\circ} \mathrm{C}$, anode/cathode: 100/75 \% relative humidity, 0/0 $\mathrm{kPag}, 2 / 2$ stoichiometry (200/200 standard $\mathrm{cm}^{3} / \mathrm{min}$ minimum flow). 

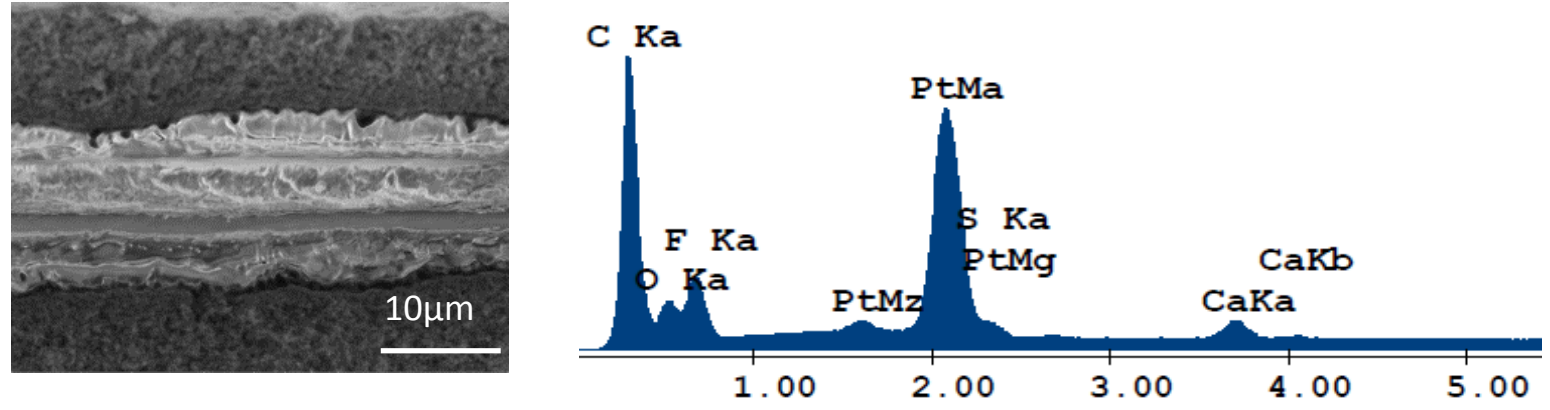

Fig. 7.4. SEM image and EDX result of CCM cross section after soaking MEA for 100h in $0.9 \mathrm{mM} \mathrm{CaSO}_{4}$ using contamination method B. EDX result shows the presence of calcium inside the CCM. 
(1) wetting agent selection

(a)

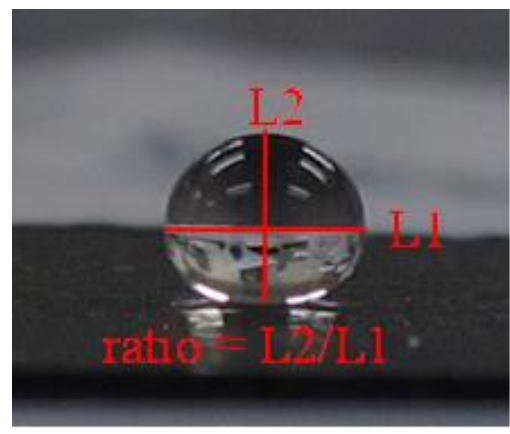

(2) Test with triton-X (Tri)

(d) GDL side

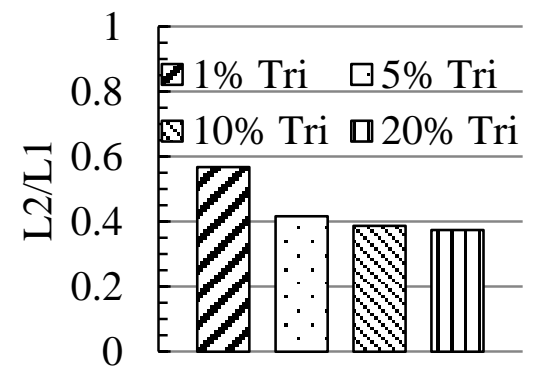

(b) GDL side

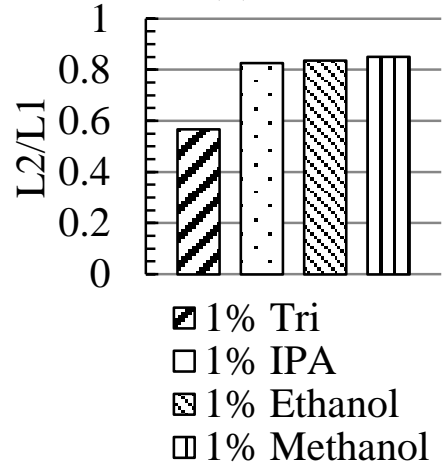

(e) MPL side

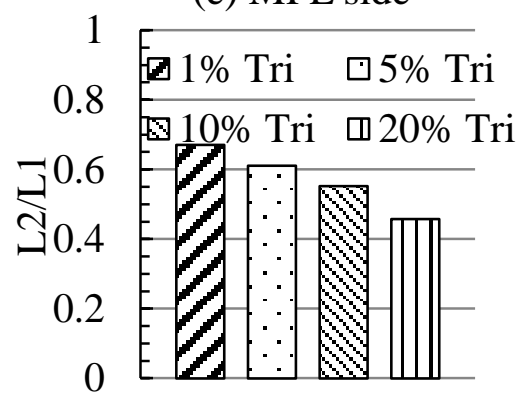

(c) MPL side

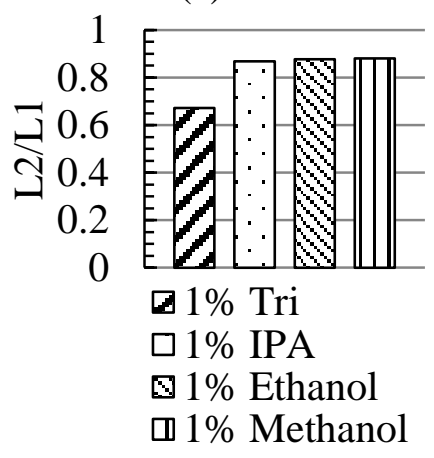

(f) After soaking MEA in $5 \%$ Tri for $24 \mathrm{~h}$

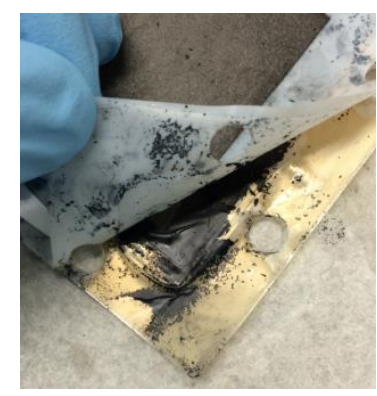

(h) MPL side

(i) Sessile drop of $25 \%$ IPA on GDL
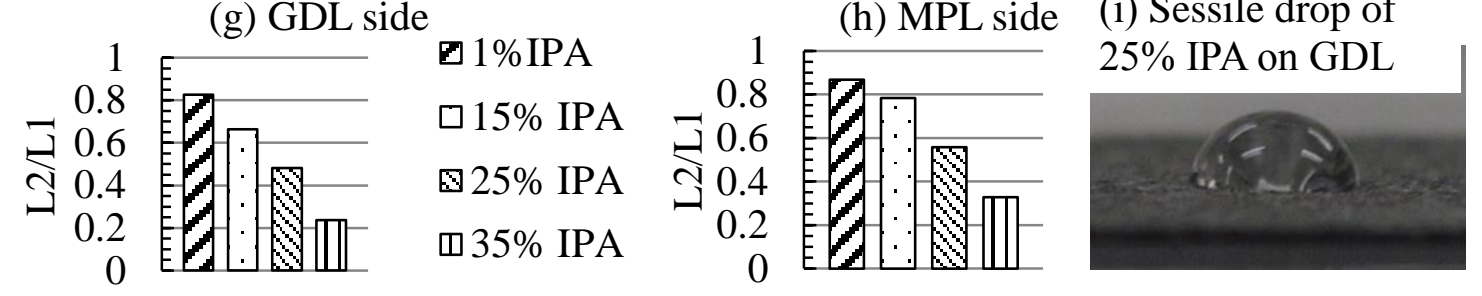

Fig. 7.5. (1) wetting agent selection: (a) sessile drop showing the characteristic dimensions, L1 (major dia), L2 (minor dia) and (b-c) ratio (L2/L1) represents the wettability of the GDL in GDL side and MPL side for $1 \%$ of Triton-X(Tri), isopropanol (IPA), ethanol, and methanol, (2) Test with triton-X (Tri): (d-e) wettability of both side of the GDL for 1\%-20\% of Triton-X and (f) image after soaking MEA in 5\% Tri for $24 \mathrm{~h}$ where it shows the separation of the catalyst layer from the CCM, (3) Test with IPA: (g-h) wettability of both sides of the GDL for $1 \%-35 \%$ of IPA and (i) sessile drop of 25\% IPA on GDL. 
$10 \% \mathrm{IPA}, 25^{\circ} \mathrm{C}$

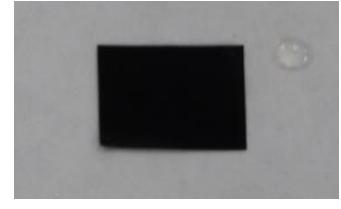

$10 \%$ IPA, $80^{\circ} \mathrm{C}$

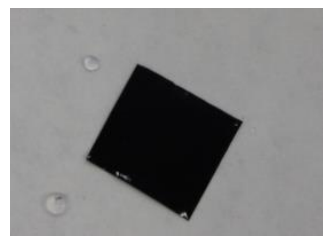

$20 \%$ IPA, $25^{\circ} \mathrm{C}$

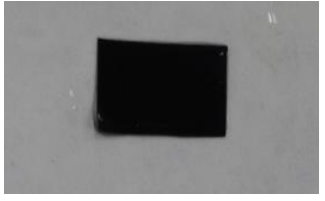

$15 \%$ IPA, $80^{\circ} \mathrm{C}$

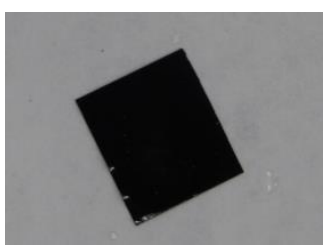

$30 \%$ IPA, $25^{\circ} \mathrm{C}$

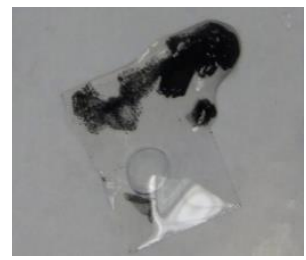

$20 \%$ IPA, $80^{\circ} \mathrm{C}$

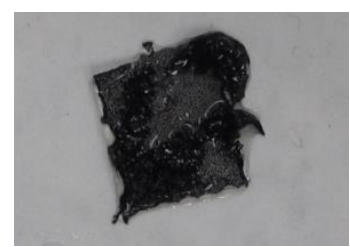

Fig. 7.6. Status of CCM after soaking in $0.9 \mathrm{mM} \mathrm{CaSO}_{4}$ and $29.1 \mathrm{mM} \mathrm{H}_{2} \mathrm{SO}_{4}$ with IPA for $24 h$. 


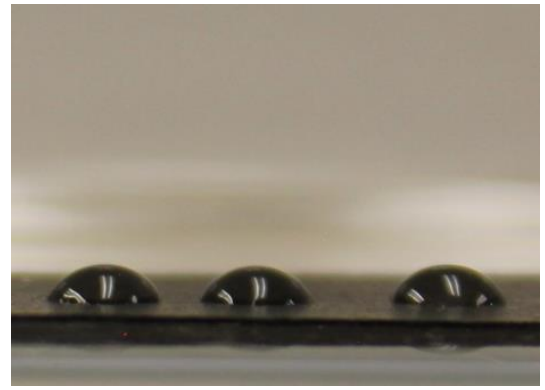

Fig. 7.7. Wettability of the dry MPL after soaking in $0.9 \mathrm{mM} \mathrm{CaSO} 4$ and $29.1 \mathrm{mM} \mathrm{H}_{2} \mathrm{SO}_{4}$ with $15 \%$ IPA for $24 \mathrm{~h}$ at $80^{\circ} \mathrm{C}$. 


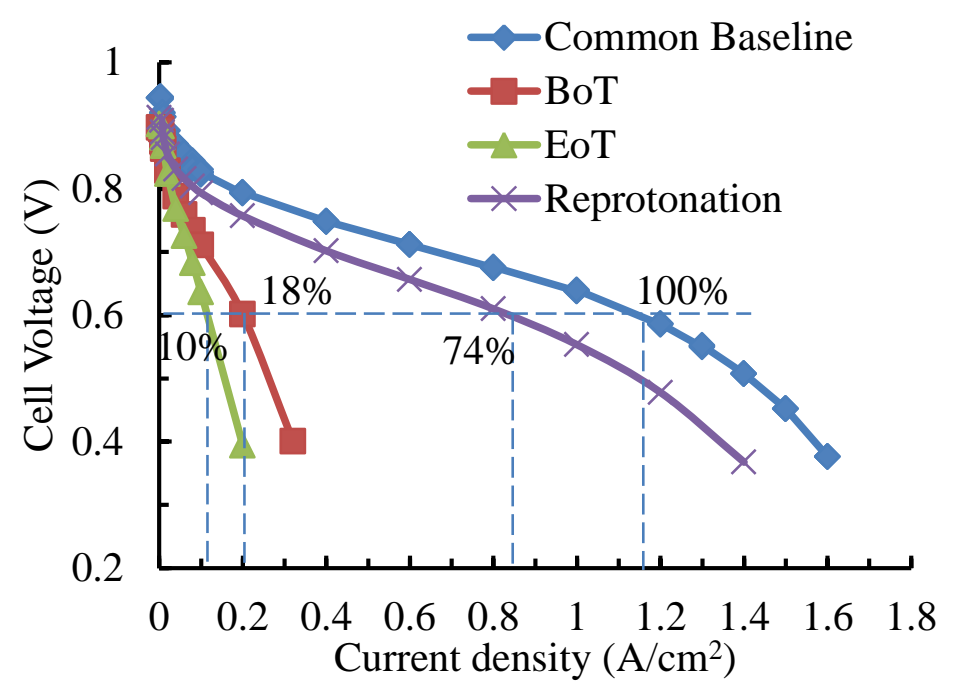

Fig. 7.8. Comparison between a common baseline polarization curve and others obtained after a $\mathrm{CaSO}_{4}$ exposure with contamination method A (beginning of test (BoT)), operation at a constant current $\left(0.1 \mathrm{~A} / \mathrm{cm}^{2}\right)$ after contaminant exposure (End of test (EoT)), and reprotonation in $1 \mathrm{M} \mathrm{H}_{2} \mathrm{SO}_{4}$ for $24 \mathrm{~h}$. Operating conditions: $80^{\circ} \mathrm{C}$, relative humidity anode/cathode: 100/75\%, 0/0 kPag, 2/2 stoichiometry (200/200 standard $\mathrm{cm}^{3}$ $\min ^{-1}$ minimum flow). 


\section{Before acid flush}
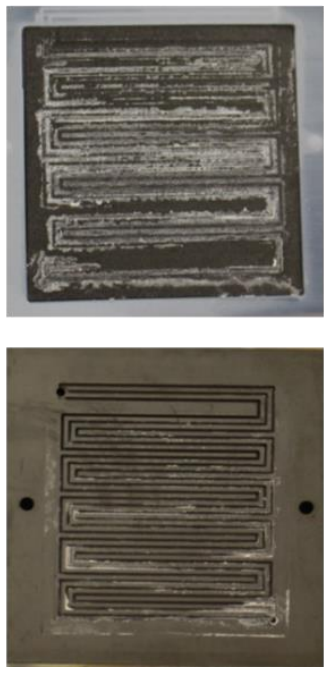

\section{After acid flush}
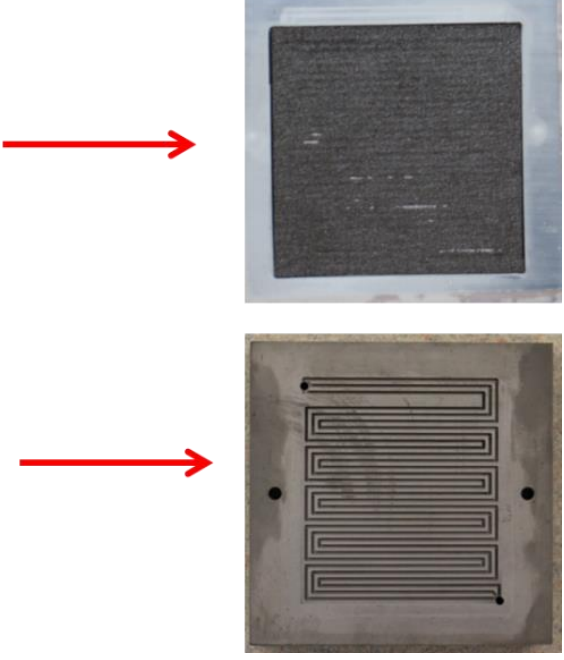

Fig. 7.9. $\mathrm{CaSO} 4$ salt deposits on a gas diffusion layer (top left) and a bipolar plate (bottom left). An in situ exposure to a $100 \mathrm{mM} \mathrm{H} 2 \mathrm{SO} 4$ solution for $3 \mathrm{~h}$ is sufficient to remove most salt deposits from the gas diffusion electrode (top right) and the bipolar plate (bottom right). 


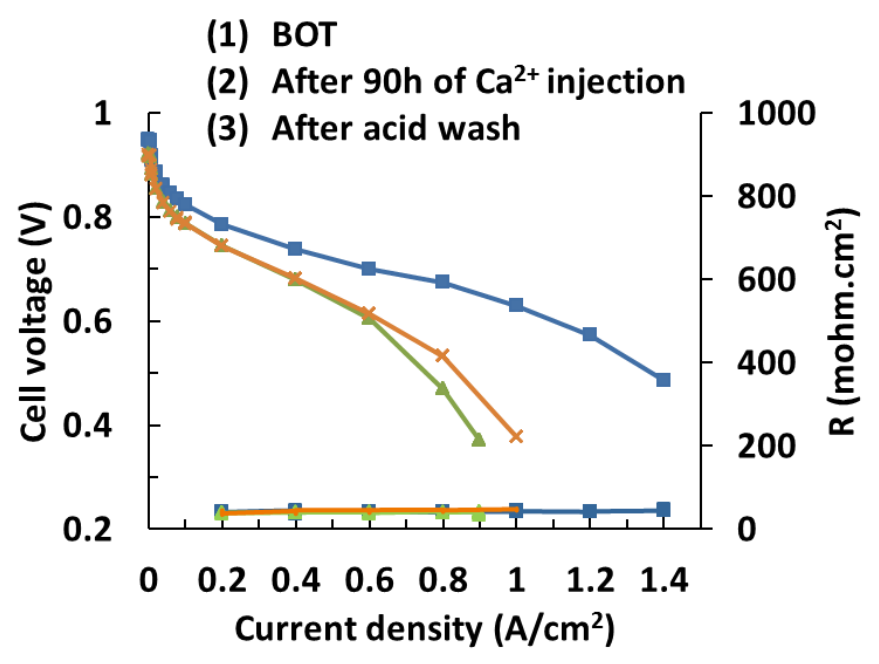

Fig. 7.10. Polarization curves obtained during and after different in situ contamination and ex-situ cleaning. 


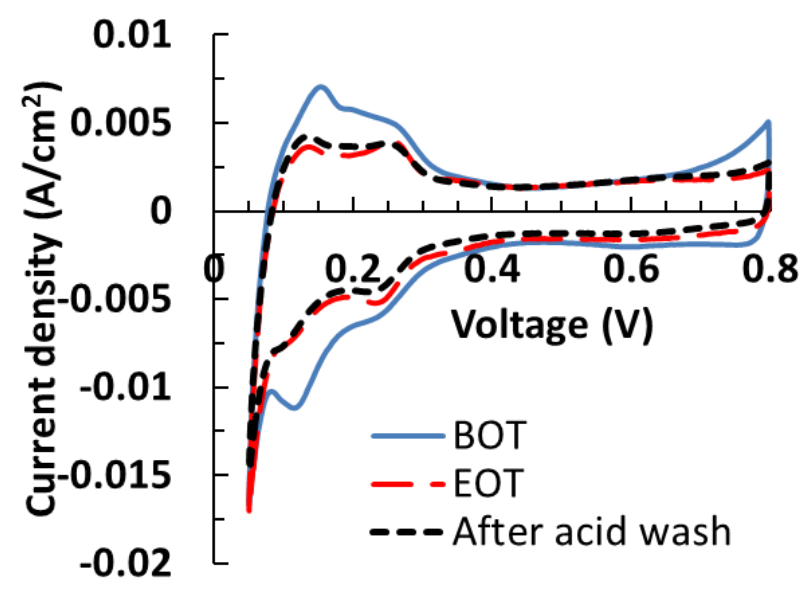

Fig. 7.11. Cathode cyclic voltammograms obtained during and after different in situ contamination and ex-situ cleaning 


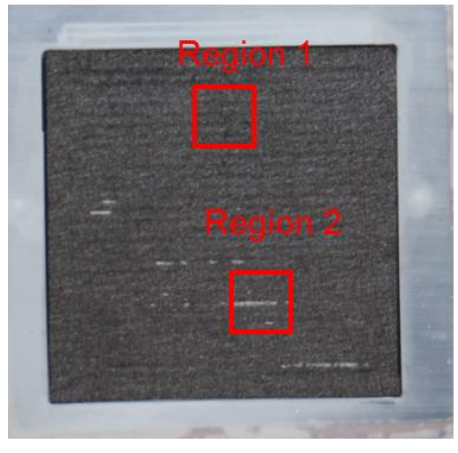

Cross section of region 1

Cross section of region 2
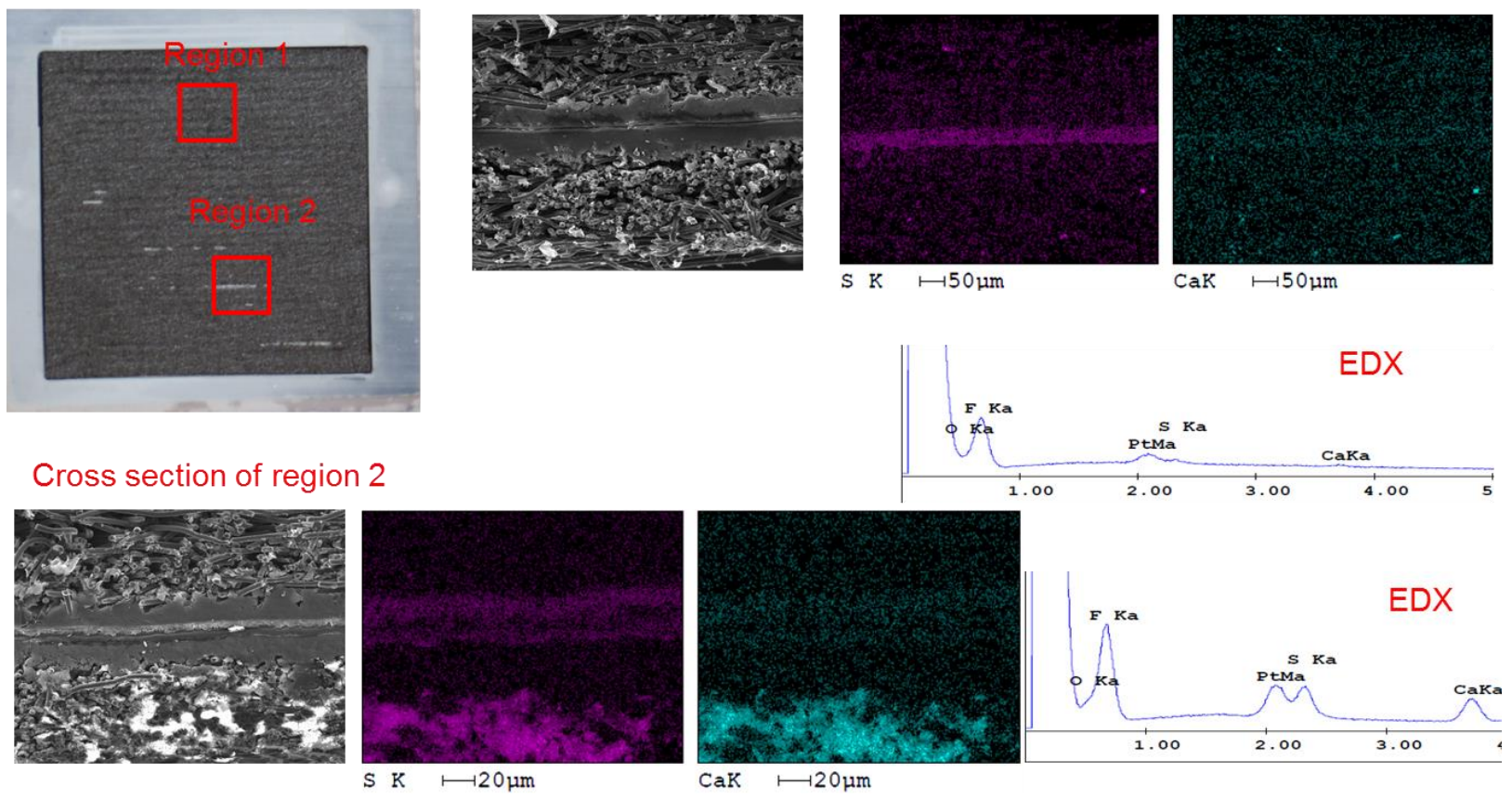

Fig. 7.12. Locations of membrane/electrode assembly cross sections examined by scanning electron microscopy and energy dispersive x-ray spectroscopy. 


\section{CONCLUSIONS AND FUTURE WORKS}

This thesis work is focused on the experimental and theoretical study of the effects of cation contaminants on the performance of PEFCs. Specifically, this work assesses the impact of a foreign cation on the durability of PEFCs, clarify the mechanisms responsible for the performance degradation by a foreign cation, devise performance recovery strategies after exposure to a foreign cation, and complete an analytical model of the cell performance affected by the presence of a foreign cation.

During screening studies, nine different cations $\left(\mathrm{Na}^{+}, \mathrm{K}^{+}, \mathrm{Mg}^{2+}, \mathrm{Ca}^{2+}, \mathrm{Ni}^{2+}, \mathrm{Ba}^{2+}\right.$, $\left.\mathrm{Al}^{3+}, \mathrm{Cr}^{3+}, \mathrm{Fe}^{3+}\right)$ with a combination of five different anions $\left((\mathrm{Cl})^{-},(\mathrm{OH})^{-},\left(\mathrm{ClO}_{4}\right)^{-}\right.$, $\left.\left(\mathrm{CO}_{3}\right)^{2-},\left(\mathrm{SO}_{4}\right)^{2-}\right)$ were investigated by injecting directly into the air stream of an operating fuel cell. During the testing of different chloride salts and hydrochloric acid, it is observed that under the same operating conditions and at a fixed chloride $\left(\mathrm{Cl}^{-}\right)$ concentration of $50 \mathrm{ppm}$ in air stream, cell performance degradation can be ranked as $\mathrm{HCl}>\mathrm{AlCl}_{3}>\mathrm{FeCl}_{3}>\mathrm{CrCl}_{3}>\mathrm{NiCl}_{2}, \mathrm{MgCl}_{2}$. The performance degradation is believed to be due to the adsorption of chloride on the Pt surface reducing active surface area. At lower RH, water content decreased and the contaminant concentration increased in the liquid water phase and salt precipitated eventually blocking some of the flow channels and the GDL surface and resulted in lower cell performance.

A steady-state, one dimensional computational model is presented in chapter 3 . Foreign cation (i.e. $\mathrm{Na}^{+}$) contamination in the air stream found to significantly decrease the performance of PEFC. The main effects are: (1) foreign cation replaces the proton and occupies the sulfonic acid sites in the ionomer. It can occupy up to $98 \%$ of the sites 
in the ionomer phase of the cathode catalyst layer (CCL). (2) It causes severe water depletion in the ionomer due to decrease in water diffusivity and equilibrium water uptake. (3) It decreases the oxygen diffusivity causing a decrease in dissolved oxygen concentration in CCL. (4) It also decreases the equilibrium potential due to reduction in proton concentration in the ionomer phase in cathode. These contamination effects on each parameter decrease protonic current density and their combined effects result in a reduction of current density from $0.72 \mathrm{~A} / \mathrm{cm}^{2}$ to $0.25 \mathrm{~A} / \mathrm{cm}^{2}$ at a constant cell voltage of $0.7 \mathrm{~V}$.

To confirm the understanding of the model, a spatial MEA was prepared and cation contamination from cathode to anode direction in PEFC were investigated at a fixed concentration of $5 \mathrm{ppm}$ of $\mathrm{Ca}^{2+}$ in the air stream of an operating fuel cell in chapter 4. At the beginning of the test, oxygen permeated from the cathode to the first layer of the membrane. After 32 hours, oxygen continued to permeate from cathode to the other layers of the membrane. The cell performance deteriorated, when $\mathrm{CaSO}_{4}$ solution was injected as a contaminant. Within 21 hours of contaminant injection, the cell voltage dropped to less than $200 \mathrm{mV}$. High frequency resistance (HFR) increased more than 50\% in the individual membrane layer that was located close to the cathode. Water management significantly affected contamination by cations which resulted in salt precipitation causing serious mass transport losses.

Distributed performance of a PEFC is also studied during in-situ injection of $\mathrm{Ca}^{2+}$ in the air stream in chapter 5 . In the galvanostatic (constant current) mode, segments near the inlet are affected first by the contaminant resulting in decreased current density. At the same time, despite the presence of contaminants, current density for the other 
segments increases in order to maintain constant total current. In the potentiostatic mode, all segments are affected by the contaminants simultaneously and the current density in all segments decreases with time. The performance of the downstream segments is lower than the upstream segments. During both tests, the contaminant is found to precipitate on both the cathode flow field and the cathode GDL surface. As the test progresses, the contaminant penetrates into the GDL and deposits, causing mass transport losses.

Moreover, experiments were conducted contaminating a catalyst coated membrane $(\mathrm{CCM})$ in $\mathrm{Ca}^{2+}$ solution prior to the cell assembly, as described in chapter 6 . It is found that the cathode catalyst layer of the contaminated CCM becomes significantly thinner over the entire active area of the CCM as compared to uncontaminated CCM. In addition, there is no significant change in the total Pt content is observed before and after the durability test. Therefore, the possible element loss that may cause significant catalyst layer thickness reduction is carbon. Since the cation tends to accumulate in the cathode catalyst layer during the fuel cell test, it is hypothesized that the accumulated cation either directly or indirectly increases the carbon oxidation reaction rate resulting in catalyst layer thinning.

It was seen that the GDL played an important role in the transport of cations. It seems that the GDL can act as a barrier to the transport of cation into the CCM, possibly due to very highly hydrophobic nature of the GDL, as shown in chapter 7 . When a wetting agent was added to the cationic solution to increase the wettability of the GDL, a drop in the performance was observed which verified that the hydrophobic GDL hindered the transport of cation into the CCM. 
Recovery strategies are explored by focusing on ion exchange procedures. When the ex-situ contaminated CCM was reprotonated, performance was almost fully recovered. Ex-situ mitigation process using acidic solution worked well, but additional factors need to be identified that hinder the full recovery process.

A complete understanding of impacts, mechanisms, and mitigation of cation contamination is not possible in a single study. A lot more efforts are necessary that lead to new research opportunities.

The computational model in this thesis is steady state and one dimensional model. It is necessary to develop models that accurately describe cation exchange between ionomer and fluid phases, which can be used to describe the role of other cell components (e.g. GDL). Additionally, time dependent processes of foreign cation transport are essential to include in the model.

One important observation reported in this thesis is that cathode catalyst layer of the contaminated CCM is found to become significantly thinner over the entire active area of the CCM as compared to the uncontaminated CCM. The total mechanism behind the catalyst layer thinning is unknown. This issue needs to be addressed.

It is found that ex-situ mitigation using acidic solution can clean cation contamination from the membrane. But it is necessary to develop an in situ mitigation process to remove cationic contamination on a real fuel cell system. Using acid flush technique, salt deposit is cleaned from the GDL and the flow field surface, but it cannot completely remove from inside the GDL. A systematic cleaning method needs to be developed. 
Finally, it is necessary to develop an effective contamination control filter. It was found that GDL can act as a barrier to the cation contamination possible due to its hydrophobic nature. This information can be utilized in filter design. 